\title{
ISOLATION AND CHARACTERIZATION OF BIOACTIVE METABOLITES FROM ENDOPHYTIC FUNGI OF PINUS STROBUS
}

by

Susan Nicole Richardson

A thesis submitted to the Faculty of Graduate and Postdoctoral Affairs in partial fulfillment of the requirements for the degree of

Master of Science

in

Chemistry with a Specialization in Chemical and Environmental Toxicology

Carleton University

Ottawa, Ontario

(C)2014, Susan Nicole Richardson 


\begin{abstract}
Fungal foliar endophytes of Pinus strobus (Eastern white pine) were collected from different sites across south-eastern New Brunswick, Canada for screening of bioactive metabolite compounds. Metabolite isolation and characterization of three bioactive strains yielded the dibenzofuran derivative porric acid C (1), one butyrolactone derivative (2), one glucopyranosol derivative (3), one furfuryl ether derivative (4), four dihydrobenzofurans derivatives (5-8), one xanthene derivative (9), and one polyoxygenated cyclohexene (10). Two of the dihydrobenzofurans compounds are new (7 and 8), while the other two (5 and 6 ) are reported here for the first time as natural products. Compound $\mathbf{4}$ is known as a starting material in the synthesis of fullerenes. The remaining compounds $(\mathbf{2}, \mathbf{3}, \mathbf{9}$, and $\mathbf{1 0})$ are also new. Compounds (1, 2, and 5-9) displayed antibacterial activity against Bacillus subtilis. Additionally, the known antifungal compound griseofulvin was quantified by LC-MS/MS.
\end{abstract}




\section{ACKNOWLEDGEMENTS}

Firstly, I would like to thank Dr. J. David Miller for giving me the opportunity to work on this important project. His guidance and encouragement throughout was invaluable. The knowledge I have gained during this time will not only serve in my future career but in all aspects of my life.

I would also like to thank all of my Miller lab mates (past and present) for sharing this experience with me; Dr. David McMullin, Jordan McFarlane, Blake Green, Natasha Prince, and especially Samantha Frasz and Dr. Tienabe Nsiama. Dr. Nsiama's patience and mentorship as well as expertise in the laboratory and in structure elucidation were instrumental to the successful completion of this project. Samantha, thank you for making me laugh like no one else can. I would also like to thank my $4^{\text {th }}$ floor neighbor Monica Gill for her friendly encouragement and support.

Finally, I would like to thank my family. Thank you for listening as I excitedly told you about my research, and for genuinely being interested in hearing about it. Thank you for being understanding, supportive and for going out of your way to make this experience a little bit easier. Nancy, thank you for being my roommate - I know it wasn't always easy. Mom, thank you for making sure I took care of myself and for helping out in any way you could. 


\section{TABLE OF CONTENTS}

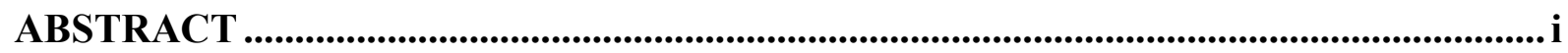

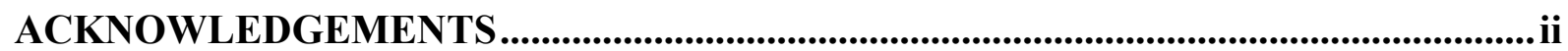

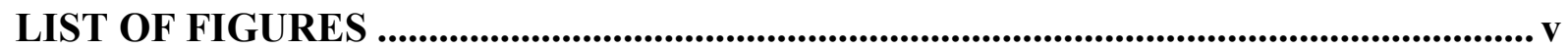

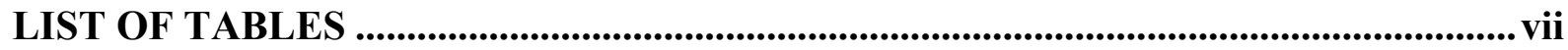

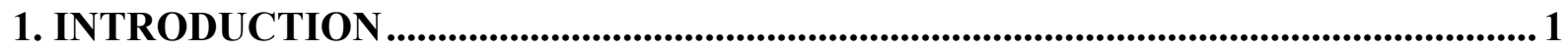

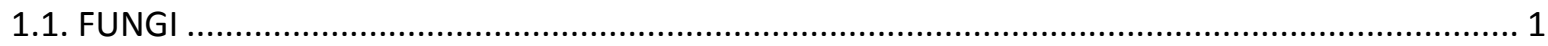

1.2. ENDOPHYTES

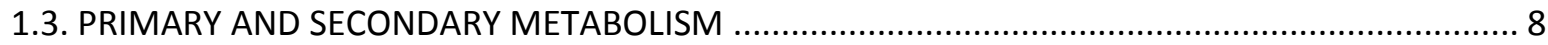

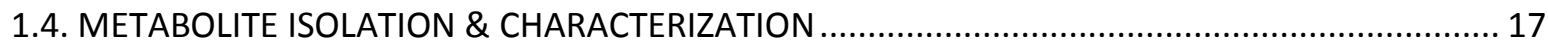

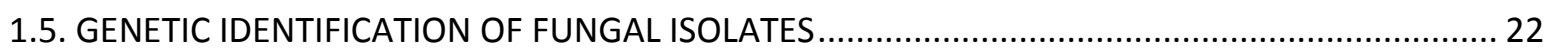

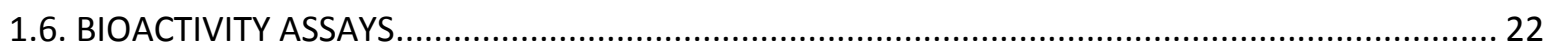

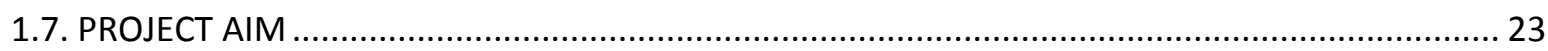

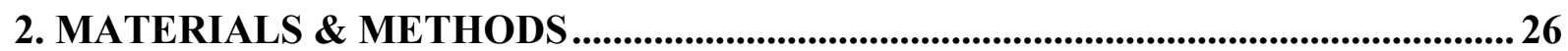

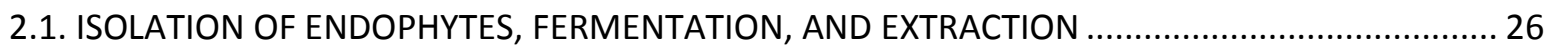

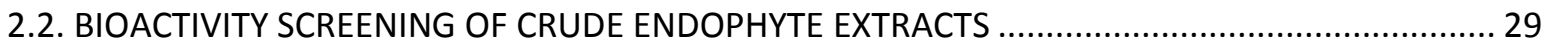

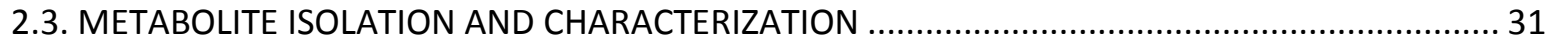

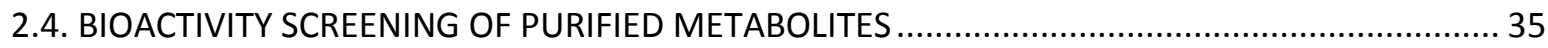

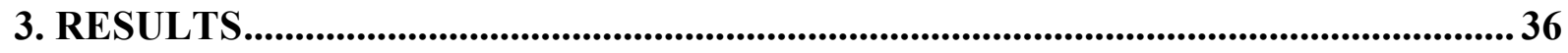

3.1. SECONDARY METABOLITES OF ENDOPHYTE ISOLATE T5.1B.1 (Xylaria species DAOM 242771)36

3.2. SECONDARY METABOLITES OF ENDOPHYTE ISOLATE SG-6 AND SG-15 (UNIDENTIFIED

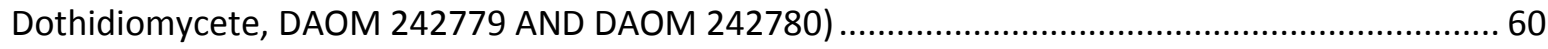

3.3. IDENTIFICATION AND QUANTITATION OF GRISEOFULVIN IN Xylaria SP.................................. 87

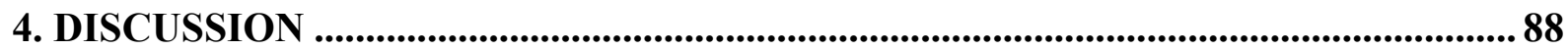

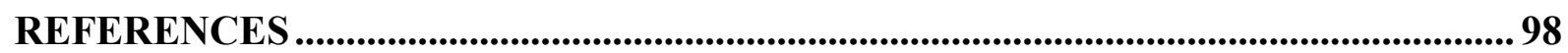

APPENDIX I - MASS SPECTRA, AND ${ }^{1} \mathrm{H}$ AND ${ }^{13} \mathrm{C}$ NMR FOR COMPOUNDS

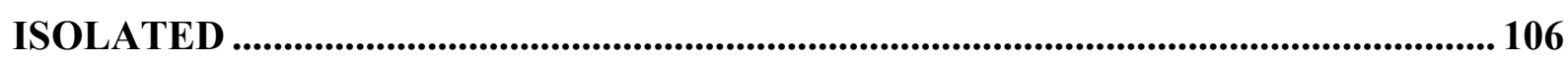


APPENDIX II - WHITE PINE ENDOPHYTE BIOACTIVITY SCREENING

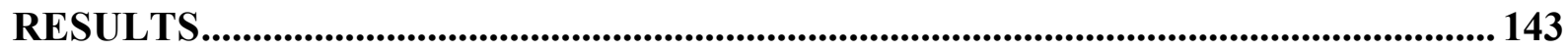




\section{LIST OF FIGURES}

\begin{tabular}{|c|c|c|}
\hline Figure & Title & Page \\
\hline 1 & Ergovaline and lolitrem B & 5 \\
\hline 2 & Rugulosin & 6 \\
\hline 3 & Scheme of enzymatic pathways for secondary metabolite production in fungi & 10 \\
\hline 4 & Acetyl-CoA and Malonyl-CoA & 11 \\
\hline 5 & Acetate pathway of polyketide biosynthesis & 12 \\
\hline 6 & Griseofulvin and pyrenophorol & 12 \\
\hline 7 & Mevalonate pathway & 14 \\
\hline 8 & Citronellal, limonene, and caryophyllene & 15 \\
\hline 9 & Shikimate pathway & 16 \\
\hline 10 & Chorismic acid and tryptophan & 16 \\
\hline 11 & Porric acid C (1) & 37 \\
\hline 12 & $\begin{array}{l}\text { Structure of 4-hydroxy-5-(hydroxymethyl)-3-methoxy-6-((3- } \\
\text { prenyloxy)isobenzofuran-1(3H)-one (2) }\end{array}$ & 41 \\
\hline 13 & $\begin{array}{l}\text { Structure of [(ethyl 3,6-dimethyl-4-prenyloxy)-2-O- } \beta \text {-D- } \\
\text { glucopyranosyl)benzoate] (3) }\end{array}$ & 44 \\
\hline 14 & Structure of 5,5'-[oxybis(methylene)]bis-furfuryl alcohol (4) & 47 \\
\hline 15 & Effect of compounds 1-2 at $100 \mu \mathrm{M}$ on cell growth of $B$. subtilis & 50 \\
\hline 16 & Effect of compounds 1-2 at $500 \mu \mathrm{M}$ on cell growth of $B$. subtilis & 51 \\
\hline 17 & Effect of compounds 1-2 at $100 \mu \mathrm{M}$ on cell growth of $P$. fluorescens & 52 \\
\hline 18 & Effect of compounds 1-2 at $500 \mu \mathrm{M}$ on cell growth of $P$. fluorescens & 53 \\
\hline 19 & Effect of compounds 3 at $100 \mu \mathrm{M}$ on cell growth of $P$. fluorescens & 54 \\
\hline 20 & Effect of compound 3 at $500 \mu \mathrm{M}$ on cell growth of $P$. fluorescens & 55 \\
\hline 21 & Effect of compound 3 at $100 \mu \mathrm{M}$ on cell growth of $B$. subtilis & 56 \\
\hline
\end{tabular}


23 Effect of compounds 1-3 at $100 \mu \mathrm{M}$ on cell growth of $S$. cerevisiae

24 Effect of compounds 1-3 at $500 \mu \mathrm{M}$ on cell growth of $S$. cerevisiae

25 Structure of (R)-2-methyl-2,3-dihydrobenzofuran-4-carboxylic acid (5)

26 Chemical structure of $(R)$-2-Methyl-2,3-dihydro-1-benzofuran

Structure of $(R)$-6-hydroxy-2-methyl-2,3-dihydrobenzofuran-4-carboxylic acid (6)

Structure of $(R)$-5,7-dichloro-6-hydroxy-2-methyl-2,3-dihydrobenzofuran-4carboxylic acid (7)

Structure of $(R)$-5,7-dichloro-6-methoxy-2-methyl-2,3-dihydrobenzofuran-4carboxylic acid (8)

30 Structure of 4-(methoxymethyl)-2-7-dimethyl-9H-xanthene (9)

31 Structure of 6-ethylidenecyclohex-4-ene-1,2,3-triol (10)

32 Effect of compounds 5-9 at $50 \mu \mathrm{M}$ on cell growth of B. subtilis

33 Effect of compounds 5-9 at $100 \mu \mathrm{M}$ on cell growth of $B$. subtilis

34 Effect of compounds 5-9 at $100 \mu \mathrm{M}$ on cell growth of $P$. fluorescens

35 Effect of compounds 5-9 at $500 \mu \mathrm{M}$ on cell growth of $P$. fluorescens

36 Effect of compounds 5-9 at $100 \mu \mathrm{M}$ on cell growth of $S$. cerevisiae $\quad 85$

37 Effect of compounds 5-9 at $500 \mu \mathrm{M}$ on cell growth of $S$. cerevisiae 86

$38 \quad$ Isolated metabolites (1-10) 


\section{LIST OF TABLES}

\begin{tabular}{|c|c|c|}
\hline Table & Title & Page \\
\hline 1 & ${ }^{1} \mathrm{H}$ and $\left(\left(\mathrm{CH}_{3}\right)_{2} \mathrm{CO}, 400 \mathrm{MHz}\right)$ and ${ }^{13} \mathrm{C} \mathrm{NMR}\left(\left(\mathrm{CH}_{3}\right)_{2} \mathrm{CO}, 100 \mathrm{MHz}\right)$ for $(\mathbf{1})$ & 38 \\
\hline 2 & $\begin{array}{l}{ }^{1} \mathrm{H} \text { and }\left(\left(\mathrm{CH}_{3}\right)_{2} \mathrm{CO}, 700 \mathrm{MHz}\right) \text { and }{ }^{13} \mathrm{C} \mathrm{NMR}\left(\left(\mathrm{CH}_{3}\right)_{2} \mathrm{CO}, 176 \mathrm{MHz}\right) \text { for } \\
\text { compound }(2)\end{array}$ & 41 \\
\hline 3 & $\begin{array}{l}{ }^{1} \mathrm{H} \text { and }\left(\left(\mathrm{CH}_{3}\right)_{2} \mathrm{CO}, 700 \mathrm{MHz}\right) \text { and }{ }^{13} \mathrm{C} \mathrm{NMR}\left(\left(\mathrm{CH}_{3}\right)_{2} \mathrm{CO}, 176 \mathrm{MHz}\right) \text { of } \\
\text { compound }(3)\end{array}$ & 45 \\
\hline 4 & $\begin{array}{l}{ }^{1} \mathrm{H} \text { and }\left(\left(\mathrm{CH}_{3}\right)_{2} \mathrm{CO}, 700 \mathrm{MHz}\right) \text { and }{ }^{13} \mathrm{C} \mathrm{NMR}\left(\left(\mathrm{CH}_{3}\right)_{2} \mathrm{CO}, 176 \mathrm{MHz}\right) \text { for } \\
\text { compound (4) }\end{array}$ & 48 \\
\hline 5 & ${ }^{1} \mathrm{H}(400 \mathrm{MHz})$ and ${ }^{13} \mathrm{C} \mathrm{NMR}$ data $(100 \mathrm{MHz})$ for compound in $\mathrm{CDCl}_{3}(\mathbf{5})$ & 61 \\
\hline 6 & ${ }^{1} \mathrm{H}(400 \mathrm{MHz})$ and ${ }^{13} \mathrm{C} \mathrm{NMR}$ data $(100 \mathrm{MHz})$ for compound $(6)$ in $\mathrm{CD}_{3} \mathrm{OD}$ & 65 \\
\hline 7 & ${ }^{1} \mathrm{H}(400 \mathrm{MHz})$ and ${ }^{13} \mathrm{C} \mathrm{NMR}$ data $(100 \mathrm{MHz})$ for compound $(7)$ in $\left(\mathrm{CD}_{3}\right)_{2} \mathrm{CO}$ & 68 \\
\hline 8 & ${ }^{1} \mathrm{H}(400 \mathrm{MHz})$ and ${ }^{13} \mathrm{C} \mathrm{NMR}$ data $(100 \mathrm{MHz})$ for compound $(8)$ in $\mathrm{CD}_{3} \mathrm{CN}$ & 72 \\
\hline 9 & ${ }^{1} \mathrm{H}$ and $\left(\mathrm{CD}_{3} \mathrm{OD}, 400 \mathrm{MHz}\right)$ and ${ }^{13} \mathrm{C} \mathrm{NMR}\left(\mathrm{CD}_{3} \mathrm{OD}, 100 \mathrm{MHz}\right)$ for 9 & 74 \\
\hline 10 & $\begin{array}{l}{ }^{1} \mathrm{H} \text { and }\left(\mathrm{CDCl}_{3}, 400 \mathrm{MHz}\right) \text { and }{ }^{13} \mathrm{C} \mathrm{NMR}\left(\mathrm{CDCl}_{3}, 100 \mathrm{MHz}\right) \text { for 6- } \\
\text { ethylidenecyclohex-4-ene-1,2,3-triol (10) }\end{array}$ & 77 \\
\hline 11 & Metabolite production of strains DAOM 242779 and DAOM 242780 & 80 \\
\hline 12 & Quantitation of griseofulvin producing Xylaria sp. & 87 \\
\hline 13 & Bioactivity screening results of white pine endophyte extracts & 144 \\
\hline
\end{tabular}




\section{INTRODUCTION}

\subsection{FUNGI}

Fungi are found on nearly every surface, in the air, soil, on other living organisms and even in seafoam. Their ability to colonize unique ecological niches as well as their ability to metabolize various types of organics, produce novel chemical structures, and reduce inorganics makes them an area of much research, including in the fields of bioremediation and toxicology. Fungi comprise one of the five eukaryotic kingdoms. The kingdom Fungi is broken down into three divisions, based on the form of the sexual reproductive structures; Zygomycetes (zygospores), Ascomycetes (ascospores) and Basidiomycetes (basidiospores). True fungi are heterotrophic, filamentous in habit and their cell walls contain chitin (Carlile et al. 2001).

Hyphae are filaments divided into compartments by cross-walls, containing several nuclei (Carlile et al. 2001). A mass of these filaments are called mycelium. In Ascomycetes and Basidiomycetes these filaments can fuse when they are in close proximity to each other, forming a complex network of mycelia that can lead to the formation of fruiting bodies (e.g., mushrooms; Carlile et al. 2001). 
Fungi have an important role in the cycling of nutrients; saprophytes decompose organic matter such as cellulose and lignin into basic building blocks that other heterotrophic organisms (e.g., plants and other microorganisms) require for growth. Other fungi such as mycorrihzae exchange nutrients with a host plant in a mutualistic relationship (Werner 1992; Carlile et al 2001).

The symbiotic relationship between fungi and plants has been known since the discovery of mycorrhizae by Frank in 1885. Mycorrhizae are fungi that envelope the roots of some plants, providing access to essential mineral nutrients such as phosphate and nitrate, as well as transporting water to the plants in exchange for glucose and other nutrients (Werner 1992).

\subsection{ENDOPHYTES}

Fungi can also live as epiphytes or endophytes of the above ground portion of the plant.

Epiphytes live on the surface of a plant's leaves, while endophytes live within its tissue (asymptomatic infection; Werner 1992). 
Lewis (1924) described a fungus living within the tissue of buds of the conifer Picea canadensis (a synonym of $P$. glauca, white spruce) from a sample collected in Alberta. In 1933, a fungal endophyte-grass relationship was described between the ascomycete Epichloë typhina and the fescue Festuca rubra by Sampson; it was also reported that E. typhina was pathogenic to the orchard grass Dactylis glomerata. At the time it was unclear what affect the fungi had on the fescue grass, however there were no visible signs of stress in the plant. It was also noted that the infected F. rubra grass produced viable seeds that contained the fungus, evidence of vertical transmission of the endophyte infection to the next generation (Sampson 1933).

Cunningham (1949) and Pulsford (1950) observed cattle grazing on tall fescue in Australia and New Zealand, respectively, presenting with a strange illness. Bacon et al. (1977) were able to establish a link between the presence of the endophyte E. typhina in tall fescue with the symptoms reported, suggesting the presence of a vasoconstricting mycotoxin. Cattle feeding on the endophyte infected fescue had symptoms including gangrenous tail tips, ears and hooves, indicating poor circulation (Bacon et al. 1977). Other symptoms reported included general ill-thrift described as decreased food intake and weight reduction as well as a thick "rough" coat (Cunningham 1949; Pulsford 1950; Bacon et al. 1977). Decreased reproduction rates and lowered milk production have also been associated with cattle 
consuming Acremonium coenophialum (a close relative of E. typhina) infected fescue (Schmidt \& Osborne 1993).

In New Zealand, "rye grass staggers' have been observed in pasture animals grazing on perennial ryegrass (Lolium perenna L.) since the early 1900's (Gilruth 1906). Neill (1940) hypothesized that these symptoms were associated with the presence of an endophytic fungi; however the hypothesis was discarded since the relationship could not be confirmed. It has since been established that the rye grass endophyte $A$. lolii is synonymous with the staggers (Mortimer et al. 1982).

The mycotoxins responsible for fescue related toxicosis and the tremorogenic staggers associated with rye grass are the neurotoxins ergovaline and lolitrem B produced by the endophytes E. typhina, A. coenophialum, and A. lolii (Figure 1; Gallagher et al. 1981; Lyons et al. 1986). 


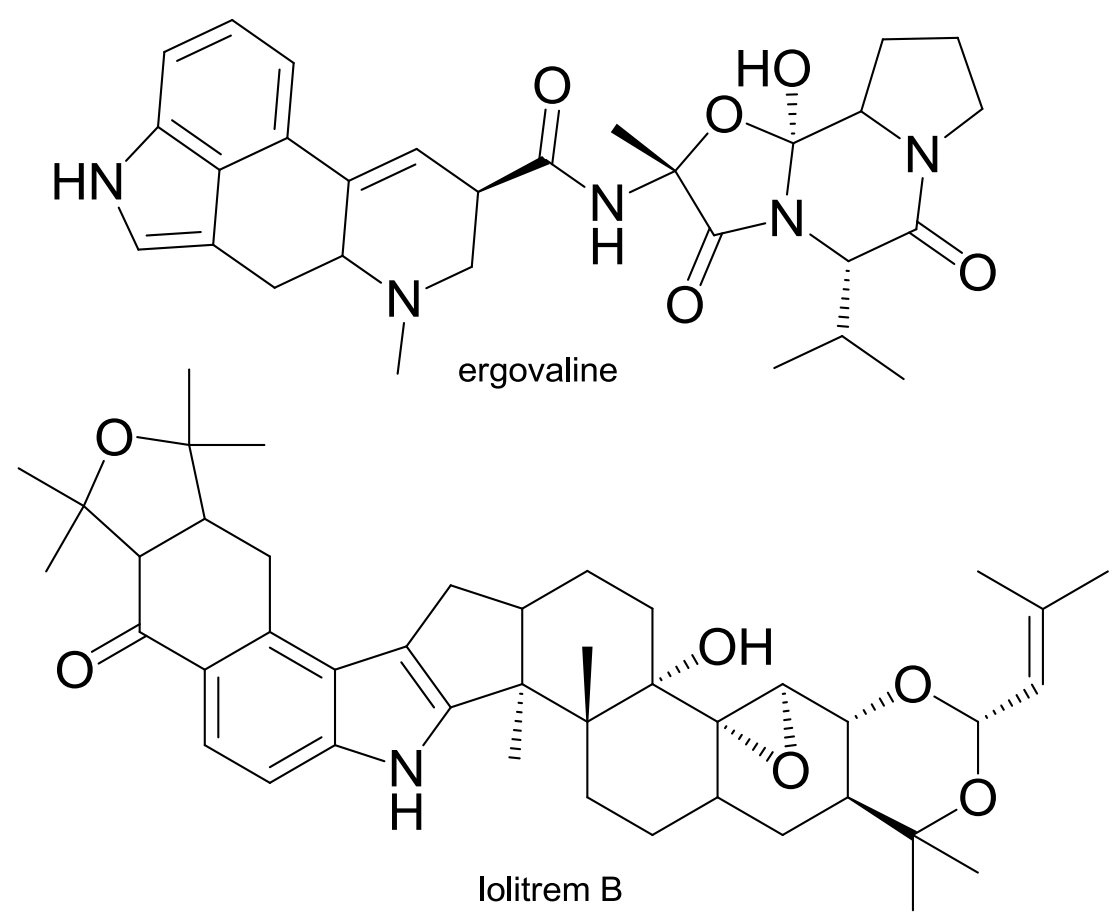

Figure 1: Ergovaline and lolitrem B.

In various studies, the endophyte infected tall fescue and rye grasses have been shown to have a higher rate of germination, produce more biomass and are also more drought tolerant than endophyte negative grasses (Read \& Camp 1986; Clay et al. 1987; West et al. 1988). They also display greater tolerance to fungal pathogens and display decreased insect herbivory (Funk et al. 1983; Barker et al. 1984; Clay 1988; Joost, 1995). The performance of these endophyte infected grasses has made them popular choices for turf -grass production where animal performance is not a factor, such as residential lawns and golf courses (Funk et al. 1997). 
Carroll \& Carroll (1978) suggested that fungal endophytes of conifer trees might form a mutualistic association with their host plant; resulting in, for example decreased palatability of the needles to herbivorous insects initiated research in this area. In 1986, Miller reported that extracts from an endophyte of Douglas fir, Rhabdocline parkerii, were toxic to the spruce budworm. The extract caused a reduction in growth rate, indicating that the endophyte may produce compounds that act as antifeedants. Miller et al. (2002) demonstrated that spruce budworm (Choristoneura fumiferana) larvae feeding on white spruce needles (Picea glauca) colonized by rugulosin producing endophytes had significantly reduced growth over those feeding on non-endophyte infected spruce needles (Figure 2). The mean rugulosin concentration in the needles was found to be $8 \mu \mathrm{g} / \mathrm{g}$, and later studies showed that there was a dose response in growth inhibition above $0.5 \mu \mathrm{g} / \mathrm{g}$ (Miller et al. 2008).

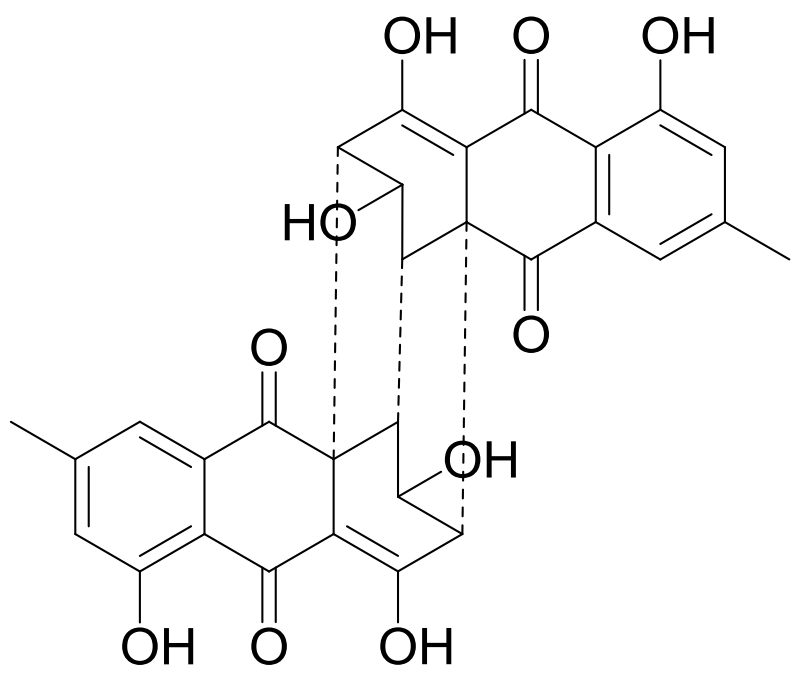

Figure 2: Rugulosin 
Miller et al. (2009) were also able to show that unlike in fescue or rye grass, transmission of foliar fungal endophytes of $P$. glauca is horizontal rather than vertical. Emerging seedlings are infected by the endophytes of cast needles from the trees around them. It is thought that the endophytes are among the first saprophytes to colonize the cast needles. When they sporulate, the surrounding trees can be infected (Hyde \& Soytong 2008; Oses et al. 2008). Following forest fires, insect damage or afforestation of agricultural land, or reforestation with nursery-grown trees, endophyte diversity is greatly reduced (Wilson et al. 1994: Miller 2011).

Sumarah et al. (2008) reported a significant reduction in the growth rate of spruce budworm larvae being fed a synthetic diet containing rugulosin. They also observed significant decreases in larval growth of the hemlock looper (Lambdina fiscellaria) and spruce budmoth (Zeiraphera canadensis).

Modest antifungal activity was observed in previous studies of anti-insect toxins from white spruce endphytes including rugulosin (Sumarah et al. 2008; 2010). This suggested that white pine endophytes might also produce compounds with such biological activity. Investigations into the metabolites produced by foliar fungal endophytes of eastern white pine (Pinus 
strobus) found potently antifungal compounds, such as pyrenophorol (Figure 6) affecting the growth of haploid cultures of Saccharomyces cerevisiae and the rust Microbotryum violaceum (Sumarah et al. 2011). Recently it has also been shown that the antifungal compound pyrenophorol, isolated from white pine endophytes, is inhibitory to white pine blister rust $(C$. ribicola) in liquid culture (Sumarah et al. submitted).

\subsection{PRIMARY AND SECONDARY METABOLISM}

The byproducts of fungal metabolism are a wide range of organic compounds including small primary metabolites, amino and fatty acids, peptides, and secondary metabolites such as penicillin, zearalenone, and statins. Fungal secondary metabolites account for many of the lifesaving antibiotics, HMG CoA reductase inhibitors (statins), and have bioactivities that make them of high value, including in cancer treatment.

Primary metabolites are those metabolites necessary for the growth of an organism, such as polysaccharides, proteins, fats and nucleic acids. The primary metabolism process is similar among all organisms (Manitto 1981). Those metabolites that utilize primary metabolites as building blocks, and are not necessary to the overall function of the organism are referred to as secondary metabolites. Secondary metabolites include compounds such as terpenes, 
alkaloids, polyketides and pigments. Although secondary metabolites may not be essential for the growth and health of the organism they often provide the organism with a competitive advantage over other species competing for nutrients by eliciting biological activity (Manitto 1981). The secondary metabolites produced and their quantities are thought to be characteristic of specific species (Hanson 2003). The idea that these secondary metabolites can be used to distinguish fungal species is called chemotaxonomy.

\subsubsection{CHEMOTAXONOMY}

Chemotaxonomy is the use of metabolites to help separate closely related fungi. While it is known that many secondary metabolites are produced by various species of fungi, the relative quantities and profile of a number of multiple secondary metabolites is thought to be species specific (Frisvad et al. 2008). This is to say that the metabolite profile of a fungus is thought to be species specific. This has proven to be an effective tool in identification of some fungal genera such as Alternaria, Aspergillus, Fusarium, and Penicillium (Frisvad et al. 2008). It can be seen from the diverse natural products isolated that their biogenesis is often complex, involving more than one metabolic pathway (Manitto 1981). 


\subsubsection{SECONDARY METABOLISM}

Fungal secondary metabolites are mostly derived from acetate and shikimic acid.

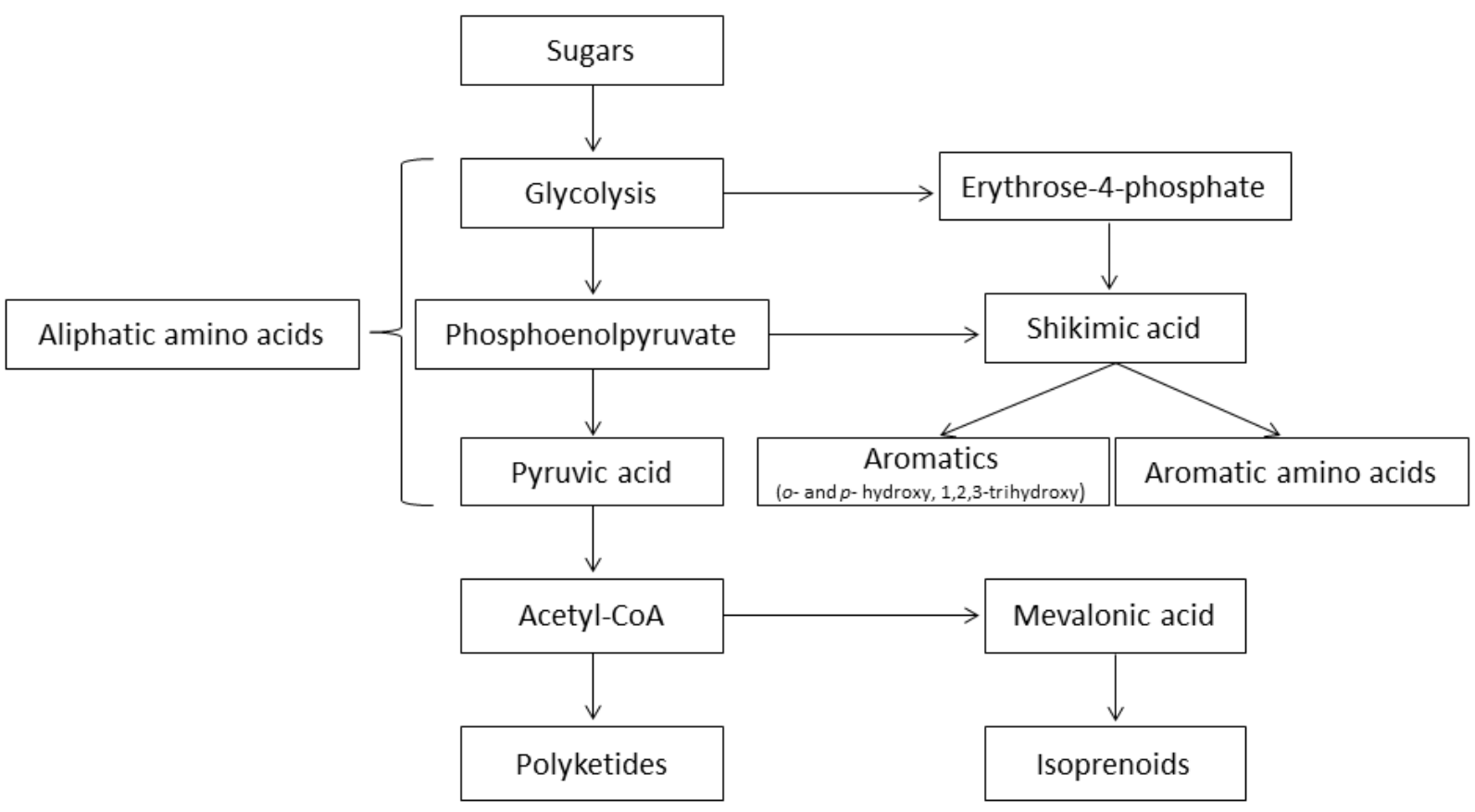

Figure 3: Scheme of enzymatic pathways for secondary metabolite production in fungi (adapted from Dewick 1997; Manitto 1981; Hanson 2003).

Besides its fundamental role in fatty acid synthesis (FAS), the primary metabolite acetate is the most common carbon source for secondary metabolites of the polyketide and terpene classes. Polyketides are derived from the activated forms of acetic acid; acetyl CoA and malonyl CoA (Manitto 1981). 

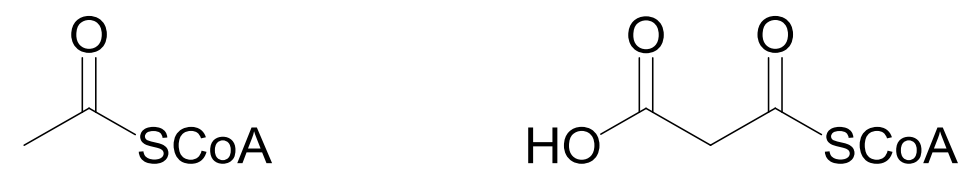

Figure 4: Acetyl-CoA and Malonyl-CoA

This biosynthetic pathway is responsible for the wide variety of secondary metabolites produced by fungi and bacteria (Manitto 1981). Highly reactive poly- $\beta$-ketoacids are formed by the sequential condensation and addition of $\mathrm{C}_{2}$ units. This reaction is similar to FAS and is catalyzed by polyketide synthases (PKS). Unlike in FAS, the growth of the polyketide chain does not require reduction of the previous carbonyl unit to a methylene group. The first $\mathrm{C}_{2}$ unit is derived from acetyl CoA while the subsequent $\mathrm{C}_{2}$ units are derived from malonyl-CoA (Figure 5). 


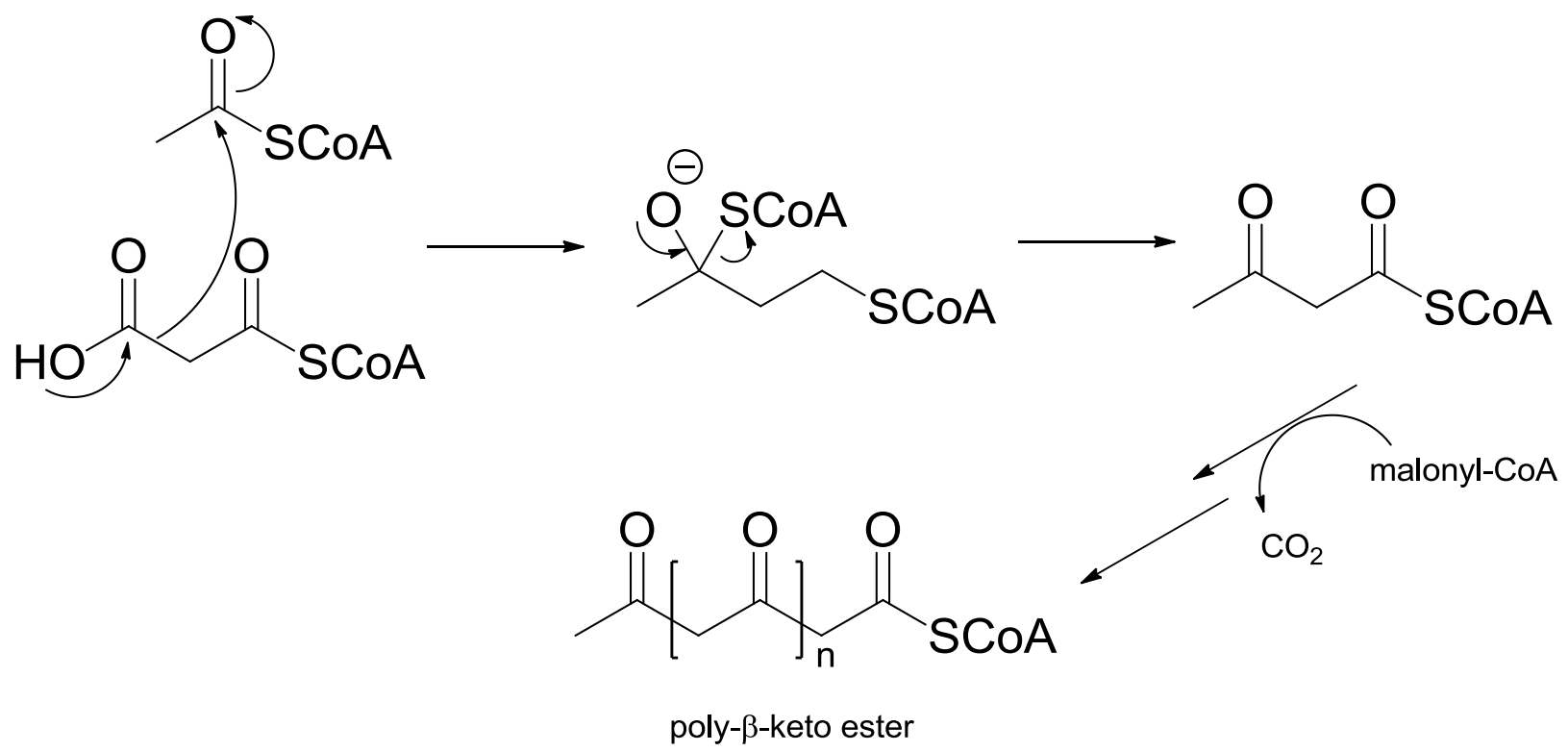

Figure 5: Acetate pathway of polyketide biosynthesis (adapted from Dewick 1997).

The polyketomethylinic chains readily undergo intramolecular reactions forming polyphenolic aromatic structures, polycyclic compounds and cyclic compounds with oxygen bridging such as $\alpha$-pyrones (Manitto 1981). For example, the known antifungal compounds griseofulvin and pyrenophorol, as well as the antibacterial erythromycin are polyketides.<smiles>COc1cc(OC)c2c(c1Cl)O[C@]1(C=CC(=O)C[C@H]1C)C2=O</smiles><smiles>CC1CCC(O)/C=C/C(=O)OC(C)CC[C@@H](O)/C=C/C(=O)O1</smiles>

Figure 6: griseofulvin and pyrenophorol 
In fungi, terpenes (or isoprenoids) are also derived from acetate, however are assembled by the condensation of $\mathrm{C}_{5}$ units through the mevalonate pathway. Two molecules of acetyl-CoA condense to give acetoacetyl-CoA which then undergoes a reaction with a third acetyl-CoA molecule to give $(S)$-3-hydroxy-3-methylglutaryl co-enzyme A (HMG-CoA). HMG-CoA is then reduced to $(R)$-mevalonic acid (Hanson 2003).

Through two successive phosphorylations, mevalonic acid is converted to 5-pyrophosphate which then undergoes a trans elimination reaction, eliminating the tertiary hydroxyl group and the carboxyl group to yield isopentenyl pyrophosphate (3-methylbut-3-enyl pyrophosphate; Hanson 2003). A reactive allylic pyrophosphate is formed when isopentenyl pyrophosphate isomerizes to give dimethylallyl pyrophosphate (3-methylbut-2-enyl pyrophosphate; DMAPP). This reactive pyrophosphate then undergoes an enzyme-catalysed reaction with isopentenyl pyrophosphate, condensing in a head-to-tail manner and adding a $\mathrm{C}_{5}$ unit with the same tail structure (i.e., same reactivity) as DMAPP (Manitto 1981; Figure 7). The reactive tail can then react further with additional isopentenyl pyrophosphate units yielding monoterpenes, sequiterpenes, etc. 


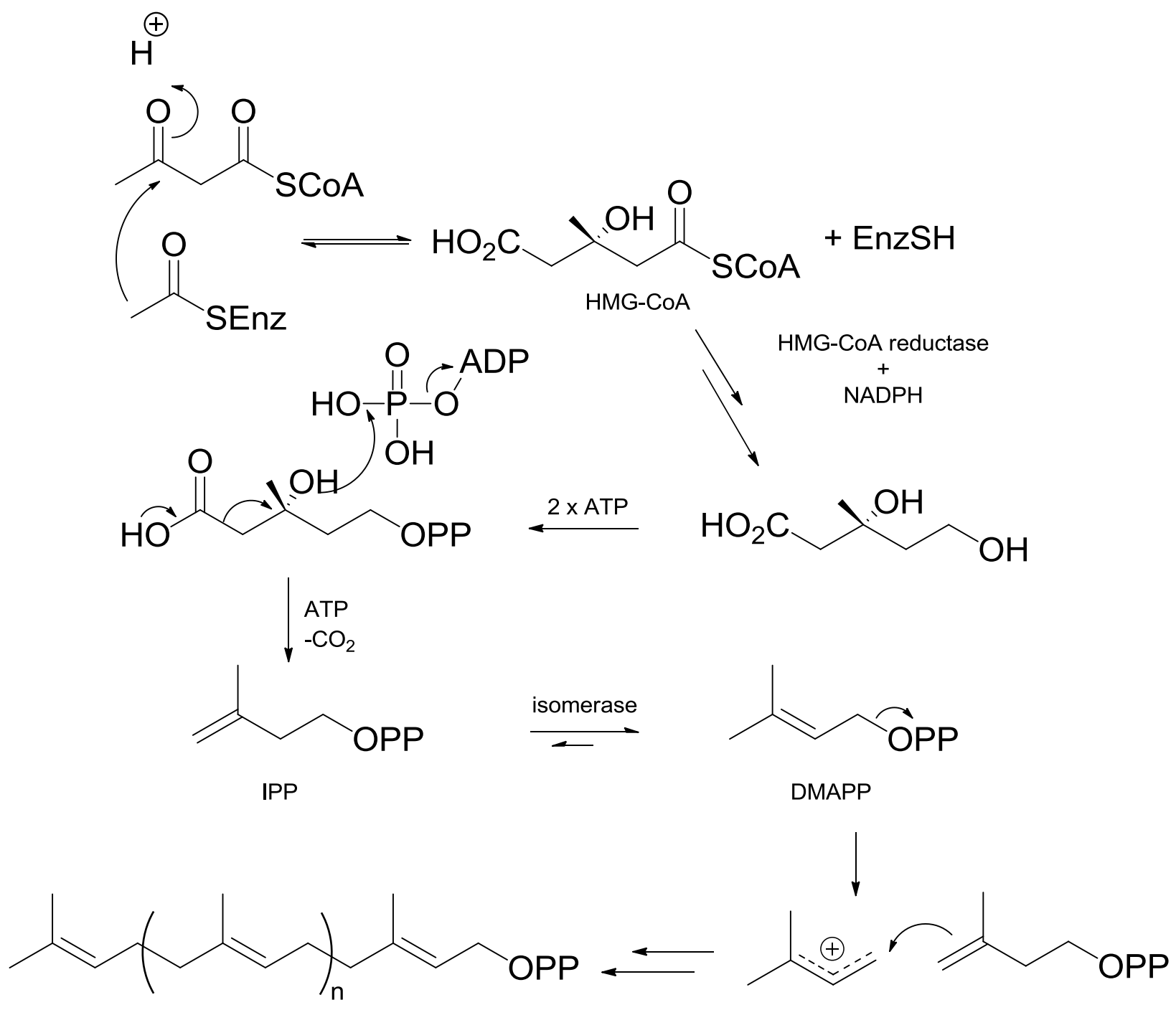

Figure 7: Mevalonate pathway (adapted from Dewick 1997; Hanson 2003)

The mevalonate pathway can lead to open chain terpenes, cyclohexanes (mono- or polycyclic), and cyclopentanes as well as other variations of these (Manitto 1981). For example, the monoterpenes citronellal, and limonene, and the sequiterpene caryophyllene are all derived (Figure 8). 

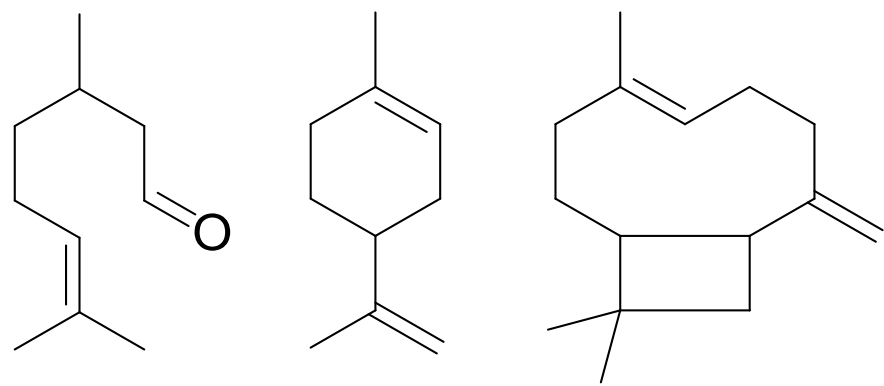

Figure 8: Citronellal, limonene, and caryophyllene.

The shikimate pathway is responsible for many families of natural products that are aromatic in nature and are derived from chorismic acid (Figure 10), such as aromatic amino acids, and benzoic acid derivatives. Their structures resemble those of tyrosine and phenylalanine, such as the compound tryptophan (Figure 10). Many ortho- and para- amino- and hydroxybenzoic acids are also derived from this pathway. The biosynthesis of shikimic acid begins with the enzyme catalyzed condensation of phosphoenol pyruvate with erythrose-4-phosphate (coming from the pentophosphate cycle) to yield heptulosonic acid (Manitto 1981; Hanson 2003). The phosphate group is then eliminated and the enolate condenses to give 3dehydroquinic acid which is further dehydrated then reduced to give shikimic acid (Figure 9; Dewick 1997; Hanson 2003). 

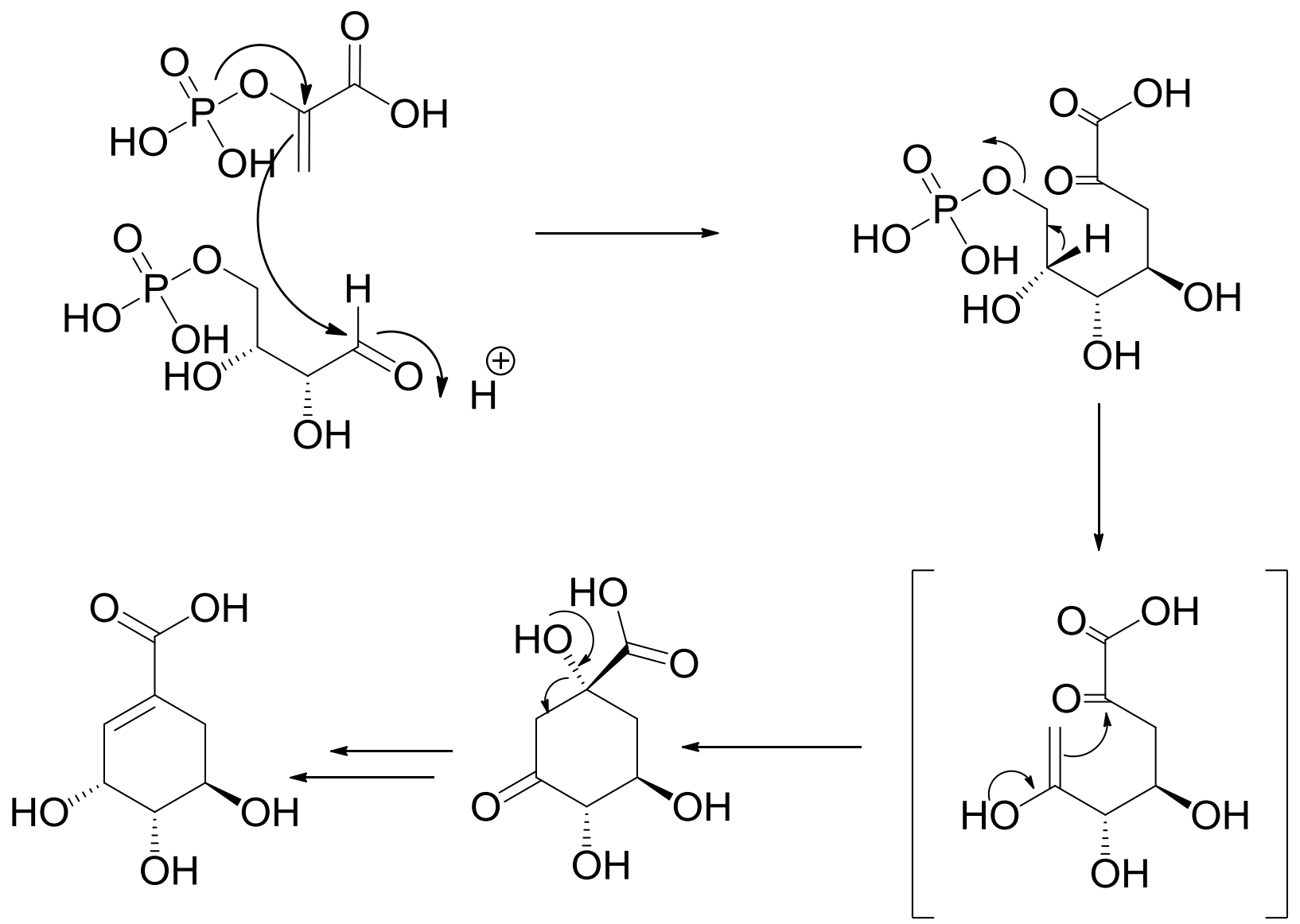

Figure 9: Shikimate pathway (adapted from Dewick 1997; Hanson 2003)<smiles>C=C(OC1C=C(C(=O)O)C=C[C@H]1O)C(=O)O</smiles><smiles>N[C@@H](Cc1c[nH]c2ccccc12)C(=O)O</smiles>

Figure 10: Chorismic acid and tryptophan 


\subsection{METABOLITE ISOLATION \& CHARACTERIZATION}

\subsubsection{ISOLATION}

Chromatography is a useful technique for the separation of compounds from a complex mixture, such as a fungal extract. Based on the physical and chemical properties of compounds and their affinities for certain solid phase materials (e.g., silica), a mixture can be separated into its individual compounds, or at least into mixtures containing fewer compounds with similar characteristics by selecting the appropriate elution solvent or solvent system (Harris 2003). Often, when working with complex mixtures such as biologicals, it is necessary to repeat the technique, varying the parameters until compounds of sufficient purity for structural characterization can be obtained or even employ many chromatographic techniques in succession.

The most common technique employed in the separation and analysis of low molecular weight secondary metabolites is reverse-phase HPLC (Frisvard, 1987). Many robust reversephase HPLC methods are described in the literature for the identification and analysis of various mycotoxins (Frisvard \& Thrane 1987). Using the same HPLC system with a larger column, semi-preparative or preparative HPLC can be used to isolate and purify individual 
compounds from a mixture. The larger sized column allows for the introduction of larger samples into the column. Individual peaks can then be collected once they exit the detector.

Isolation of pure metabolites is essential for structural elucidation. Once a pure metabolite has been isolated, mass spectrometry along with 1D and 2D NMR experiments are used to unambiguously elucidate the chemical structure.

\subsubsection{CHARACTERIZATION}

\subsubsection{MASS SPECTROMETRY}

The mass of a pure compound is determined using mass spectrometry (MS). Often a gas or liquid chromatography (GC or LC respectively) system is coupled to a mass spectrometer. Coupling an LC system to an electrospray ionization (ESI) MS system allows for the sample to be dissolved in a solvent, introduced into the LC system, separated into its individual components and then transferred to the gas phase (without decomposition) and ionized before entering the mass analyzer (Pavia et al. 2009; Kebarle \& Verker 2010). 
ESI-MS is a useful technique for analyzing high molecular weight biomolecules as well as small non-volatile compounds (Pavia et al. 2009). It is especially useful when trying to characterize unknown compounds since it may not be known if the compounds are thermally stable (Pavia et al. 2009). ESI is a soft ionization technique that, when operated in positive mode, often produces the protonated molecular species $\left([\mathrm{M}+\mathrm{H}]^{+}\right)$for a variety of different types of compounds (Smedsgaard \& Nielsen 2005). Other ions that are often observed include $[\mathrm{M}+\mathrm{H}+\mathrm{ACN}]^{+},\left[\mathrm{M}+\mathrm{H}-\mathrm{H}_{2} \mathrm{O}\right]^{+},[\mathrm{M}+\mathrm{Na}]^{+}$, and $[2 \mathrm{M}+\mathrm{H}]^{+}$. The mass spectrum analysis can also provide other useful information about the compound being studied. For example, molecules containing chlorine or bromine atoms will display two molecular ion peaks; one for each of its commonly occurring isotopes. This is referred to as the molecular ion cluster (Pavia et al. 2009). A significant $M+2$ peak can be observed when either chlorine or bromine is present since their heavier isotopes are two mass units heavier than the lighter isotope. The relative intensities of the $M+2$ peaks should be consistent with the relative abundance of the isotope (Pavia et al. 2009). Mass spectrometry is a very sensitive technique, critical to the analysis of secondary metabolites. 


\subsubsection{NMR}

In conjunction with the mass of the compound, both ${ }^{13} \mathrm{C}$ and ${ }^{1} \mathrm{H}$ NMR data are necessary to properly characterize a metabolite. Obtaining a 135-DEPT spectrum can also be useful since it can help to assign carbons as quaternary, methylene, methine or methyl. To be able to correlate proton signals with their corresponding carbon signals, or to determine whether they belong to an amine or hydroxyl group, heteronuclear correlation spectroscopy is employed (Balci 2005). Heteronuclear chemical shift correlation (HETCOR), or heteronuclear singlequantum correlation (HSQC) reveal the correlation between protons and carbons with a two dimensional plot. HSQC is a ${ }^{1} \mathrm{H}$-detected experiment whereas HETCOR is an X-detected experiment (here ${ }^{13} \mathrm{C}$ ). Since ${ }^{1} \mathrm{H}$ protons are more abundant than ${ }^{13} \mathrm{C}$ atoms, and have a higher magnetogyric ratio they are easier to detect and therefore result in a more resolved spectrum obtained over a shorter period of time (Balci 2005; Pavia et al. 2009). HETCOR would be a more useful technique when the carbon spectrum is crowded and better resolution of that parameter is required (Pavia et al. 2009). In HSQC the $\mathrm{f}_{1}$ axis displays the ${ }^{1} \mathrm{H}$ spectrum, while the $\mathrm{f}_{2}$ axis displays the ${ }^{13} \mathrm{C}$ spectrum. Cross-peaks indicate which protons are connected to which carbon atom (Balci 2005). Heteronuclear multiple-bond correlation (HMBC) shows two, three and four bond correlations between protons and carbons, suppressing the one bond correlations (Balci 2005). This gives much needed information about the connectivity of 
carbons (indirectly; Balci 2005). Additional 2D techniques such as COSY and NOESY are often required when analyzing complicated or novel compounds.

\subsubsection{UV-VIS}

Ultraviolet and visible spectroscopy are of limited use in characterizing compounds, however, along with infrared spectroscopy and NMR can provide valuable structural information to support a potential structure. For example, it is possible to correlate certain absorptions in the UV-VIS wavelengths range with features such as the presence of alkenes, and carbonyls (Pavia et al. 2009).

\subsubsection{IR}

Each type of bond in a molecule absorbs a different frequency of energy. Therefore certain characteristic absorptions in the infrared region (IR) can give valuable information on the structure of the compound being analyzed. For example the presence of a broad O-H stretch in the range of $3400-2400 \mathrm{~cm}^{-1}$ and a carbonyl stretch between 1730 and $1700 \mathrm{~cm}^{-1}$ indicates the presence of a carboxylic acid. Unless two compounds are identical it is not possible to use 
an IR spectrum to identify an unknown metabolite, however it can be used to confirm the presence of certain chemical features (Pavia et al. 2009).

\subsection{GENETIC IDENTIFICATION OF FUNGAL ISOLATES}

The genetic identity of fungal isolates was determined by isolating and amplifying DNA sequence data from the internal transcribed spacer (ITS) region of the rRNA. The ITS sequence has been established as the primary fungal barcode (Schoch et al. 2012). Where genetic matches were not identified performing BLAST searches of the ITS sequence, attempts were made to identify the species morphologically.

\subsection{BIOACTIVITY ASSAYS}

Various types of bioactivity assays exist. In vitro tests are easier to perform and less expensive than in vivo bioassays. Perhaps the easiest of them all is the paper-disc agar-plate method (De Beer \& Sherwood 1945). There are many modifications to this type of assay but as long as a positive control is used and the established procedure is followed it is of suitable reproducibility. A compound of interest (or mixture of compounds) is loaded onto a paper disc and placed onto an agar plate inoculated with a lawn of a microorganism of interest along with a negative and positive control. The growth on the plate is observed over a given period 
of time and the inhibition zone is measured. Comparing the inhibition zone of the compound of interest with the positive control allows for a qualitative comparison of the bioactivity.

A more quantitative in vitro bioassay employing a cell suspension of a microorganism in a 96 well microplate can be used to monitor the effect of a compound on growth over time. This assay measures the optical density of a cell suspension and is useful in determining the minimum inhibitory concentration (MIC) of a compound. The test parameters allow for quantitative comparison of growth over time with a positive control (Sumarah et al. 2011).

\subsection{PROJECT AIM}

Research conducted over many years suggests that the presence of endophytes and the metabolites they produce can confer tolerance of the host plant towards pathogenic agents such as Cronartium ribicola (white pine blister rust) and the insect Choristoneura fumiferana (eastern spruce budworm; Ganley et al. 2008; Sumarah et al. 2011; Sumarah et al. submitted).

Canada's forestry industry contributes to the employment of approximately 600,000 Canadians and accounts for $2 \%$ of Canada's gross-domestic product, however, this industry is 
being threatened (Natural Resources Canada, 2011). The Canadian forestry industry has been threatened by the parasitic insects and pathogenic fungi, such as spruce budworm, pine beetle, white pine weevil and white pine blister rust, among others. These forest pests have decreased the quantity of viable trees for harvesting and thus have impacted the export and production of both primary forestry products (lumber and building materials) and manufactured wood products. For example, in 2010, 68\% of Quebec's eastern white pine plantations were found to be infected with white pine blister rust. The Government of Canada (2011) has noted that due to the effects of white pine blister rust, reforestation of white pine has dramatically decreased and it is no longer seen as a viable commercial source of soft wood in western Canada. In terms of mediating the infections of these pests the main methods currently employed are silvicultural (i.e. pruning), chemical spraying and in the case of spruce budworm a bio-control agent (Bacillus thuringiensis).

Based on reports of endophytes providing tolerance of their host plant to fungal pathogens as well as parasitic insects, it was hypothesized that endophytes of white pine may produce antifungal compounds in planta that help provide tolerance of the plant to this or other pathogens, and that seedlings could be inoculated with a strain of fungi producing these metabolites without causing harm to the plant itself. 
A collection of 536 foliar fungal endophytes were isolated from the needles of 75-100 year old white pine trees from five sites across New Brunswick. Nearly $25 \%$ of the strains were grown in liquid culture and their crude extracts tested for bioactivity against the yeast Saccharomyces cerevisiae and the rust fungus Microbotryum violaceum. Those extracts that displayed bioactivity by inhibiting the growth of the two microorganisms were grown in bulk quantities. Their major metabolites were isolated using various chromatographic techniques including column chromatography, and high-performance liquid chromatography (HPLC) and their structures elucidated using mass spectrometry, and nuclear magnetic resonance spectroscopy (NMR).

The results of these studies are reported here. 


\section{MATERIALS \& METHODS}

\subsection{ISOLATION OF ENDOPHYTES, FERMENTATION, AND EXTRACTION}

\subsubsection{ISOLATION OF PINE NEEDLE ENDOPHYTES}

Branches from 75-100 year old white pine trees at five different sites across New Brunswick were collected and shipped under cold conditions to the laboratory. A total of 26 trees were

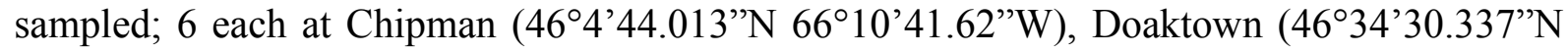
66²'57.003”W), Deersdale $\left(46^{\circ} 6^{\prime} 30.792^{\prime} \mathrm{N} \quad 66^{\circ} 50^{\prime} 40.507^{\prime \prime} \mathrm{W}\right), \quad$ and Saint-George $\left(45^{\circ} 25^{\prime} 17.282^{\prime} \mathrm{N} 66^{\circ} 30^{\prime} 10.135^{\prime \prime} \mathrm{W}\right)$ and 2 at Sussex $\left(45^{\circ} 44^{\prime} 02.316^{\prime \prime} \mathrm{N} 65^{\circ} 28^{\prime} 43.388^{\prime \prime} \mathrm{W}\right)$. A number of living green needles were removed from each branch; surface sterilized, bisected and incubated on $2 \%$ malt extract (Difco) agar plates (MEA) at $25^{\circ} \mathrm{C}$ in the dark.

Surface sterilization was carried out by immersing the needles in $70 \%$ ethanol for one minute, and then rinsed with sterile deionized water, followed by a 7.5 minute immersion in $10 \%$ bleach solution. After soaking in the bleach solution the needles were placed in $70 \%$ ethanol once more briefly, and then rinsed with distilled water. Using sterilized forceps each needle was carefully bisected cross-wise then plated on MEA plates for incubation. Needles were incubated at $25^{\circ} \mathrm{C} \pm 1{ }^{\circ} \mathrm{C}$ until growth was observed from the exposed needle tip. The isolates 
were then subcultured and plated onto fresh MEA plates and placed back in the incubator. Once it was determined that the cultures had grown sufficiently for inoculation of liquid media they were wrapped with Parafilm and place in a refrigerated incubator at $9^{\circ} \mathrm{C} \pm 1{ }^{\circ} \mathrm{C}$ until needed.

A collection of 536 isolates were obtained from these needles $(38,336,111,32$ and 19 from each of the sites respectively). Approximately $25 \%$ of the strains were chosen for metabolite screening.

\subsubsection{FERMENTATION}

A plug of mycelium was removed from the agar plate, and placed in a sterile beaker containing distilled deionized water (5\% of the culture volume). The mycelium was macerated and then transferred to a Glaxo bottle containing $1 \mathrm{~L}$ of sterile $2 \%$ malt extract media for fermentation over 8 weeks at $25^{\circ} \mathrm{C} \pm 1{ }^{\circ} \mathrm{C}$. 


\section{Bulk cultures}

A first stage fermentation was carried out for bulk cultures to ensure proper growth. Starter cultures were prepared by macerating a plug of mycelium in distilled deionized waters as described above. The macerated culture ( $5 \%$ of the culture volume) was then transferred to $250 \mathrm{~mL}$ Erlenmeyer flasks containing $50 \mathrm{~mL}$ of $2 \%$ malt extract media for fermentation. These starter cultures were then placed on a rotary shaker until growth was observed. They were then removed from the shaker and allowed to continue growing in the dark for approximately 2 weeks before being macerated and transferred to Glaxo bottles for 8 weeks of fermentation.

\subsubsection{EXTRACTION}

The contents of each Glaxo bottle were filtered under suction through a Büchner funnel lined with a Whatman No. 4 filter paper. The filtrate was collected and the volume and $\mathrm{pH}$ measured. The cells were collected and frozen for future use.

\section{Liquid-liquid extraction}

Using a 2 L separatory funnel, the filtrate from each 1 L Glaxo bottle was saturated with sodium chloride and chemically extracted with $1 \mathrm{~L}$ of ethyl acetate (EtOAc). The organic 
phase was collected in 2 L Erlenmeyer flasks, dried over sodium sulfate, and filtered through

a Whatman No. 1 filter paper. The solvent was then evaporated under vacuum using a rotary evaporator. Once the solvent had been removed the extract was disolved in 2-3 $\mathrm{mL}$ of methanol $(\mathrm{MeOH})$, and then filtered through a $0.20 \mu \mathrm{m}$ polytetrafluoroethylene (PTFE) syringe filter (VWR). Filtered samples were then screened by LC-MS to identify compounds of interest and screened for bioactivity.

\subsection{BIOACTIVITY SCREENING OF CRUDE ENDOPHYTE EXTRACTS}

Crude extracts were screened for antifungal properties using a modified Oxford disc diffusion assay. A $50 \mathrm{mg} / \mathrm{mL}$ sample of each crude extract was prepared in chloroform (for complete evaporation of the solvent). Using a micropipette $10 \mu \mathrm{L}$ of each crude extract was loaded onto three separate $10 \mathrm{~mm}$ Whatman No. 1 filter papers and allowed to dry in a sterile environment overnight. Three replicate discs for positive and negative controls (nystatin Sigma-Aldrich and $\mathrm{CHCl}_{3}$ respectively) were also prepared and allowed to dry overnight.

MEA plates were inoculated with a cell suspension of either $S$. cerevisiae or M. violaceum. Even coverage of the plate was ensured by using a using a sterile bent glass rod. Plates were 
then allowed to dry in a sterile environment (approximately $4 \mathrm{hrs}$ ) before the discs were loaded.

S. cerevisiae cultures were prepared by placing $0.25 \mathrm{~g} / \mathrm{L}$ of dry yeast to an Erlenmeyer flask containing sterile water and $1 \mathrm{~g} / \mathrm{L}(+)$-D-glucose. The flask was then placed on a rotary shaker and allowed to incubate for $16 \mathrm{hrs}$ (overnight).

M. violaceum cultures were inoculated using a sterile loop. A small amount of the rust fungus was transferred to a $250 \mathrm{~mL}$ Erlenmeyer flask containing sterile 2\% MEA liquid media. The rust culture was left to incubate at $25^{\circ} \mathrm{C} \pm 1{ }^{\circ} \mathrm{C}$ for approximately 10 days before use.

Once the plates were dry the paper discs were arranged (4 to a plate to ensure adequate spacing) and then the plates were incubated at $25^{\circ} \mathrm{C} \pm 1^{\circ} \mathrm{C}$ overnight.

Each plate was observed and any growth inhibition noted. Extracts displaying antifungal activity against $S$. cerevisiae or $M$. violaceum were candidates for bulk growth and metabolite isolation. 


\subsection{METABOLITE ISOLATION AND CHARACTERIZATION}

\subsubsection{VACUUM CHROMATOGRAPHY}

A flash chromatography column was prepared in a Whatman No. 1 filter paper lined Büchner funnel. The funnel was packed with silica gel (230-400 mesh, 40-63 $\mu \mathrm{m}, 60$ Ả, Caledon Laboratories) silica powder, covered with another filter paper and saturated with $\mathrm{CHCl}_{3}$. Crude extract was dissolved in $\mathrm{MeOH}$ in a $100 \mathrm{~mL}$ round-bottom flask. A slurry of silica was mixed in and the solvent evaporated using a rotary evaporator. This allowed for the extract to be fully adsorbed to the silica before being loaded onto the flash chromatography column. The solid extract was covered with another filter paper before being eluted using vacuum with a gradient of hexanes in EtOAc, and then $\mathrm{MeOH}$ in EtOAc.

The fractionated mixture was then analyzed by LC-MS to identify fractions of interest, and depending on the composition was either separated further by column chromatography followed by semi-preparatory HPLC or directly to semi-preparatory HPLC.

\subsubsection{FLASH COLUMN CHROMATOGRAPHY}

A chromatography column was prepared by creating silica gel slurry (230-400 mesh, 40-63 $\mu \mathrm{m}, 60 \AA$ A , Caledon Laboratories) in chloroform $\left(\mathrm{CHCl}_{3}\right)$. The slurry was poured gently into 
the column to avoid the production of air bubbles and packed with gentle forced air. The column was then washed with $\mathrm{CHCl}_{3}$ and then prepared by running an adequate amount of the first solvent mixture through. Crude extract was dissolved in an appropriate solvent then loaded onto the column.

The column was then eluted with a gradient of hexanes in EtOAc, followed by $\mathrm{MeOH}$ in EtOAc under forced air.

Fractions were collected in $10 \mathrm{~mL}$ glass cuvettes. Like fractions were combined and the solvent was evaporated under vacuum using a rotary evaporator.

\subsubsection{SEMI-PREPARATIVE HPLC}

Semi-preparative HPLC was performed using an Agilent 1100 HPLC system with a variable wavelength detector and a SUPELCO Ascentis $\mathrm{C}_{18}$ column $(5 \mu \mathrm{m}, 25 \mathrm{~cm}$ x $10 \mathrm{~mm})$ (Supelco, Bellefonte, PA, USA) in gradient mode. A gradient solvent system of $10-95 \%$ acetonitrile in deionized water and water at a flow rate of $4 \mathrm{~mL} / \mathrm{min}$ for $20-25$ minutes was used. The gradient system and run time was adjusted per fraction in order to establish better resolution of peaks. 


\subsubsection{MASS SPECTROMETRY}

Compounds were analyzed using a Waters 2795 separations module LC system connected to a Waters 996 diode array detector and Micromass Quatro on a Phenomenex Kinetix $\mathrm{C}_{18}$ column (2.6 $\mu \mathrm{m}, 100 \AA, 100 \times 4.60 \mathrm{~mm})$ using acetonitrile and water (with formic acid $0.1 \%$ $\mathrm{v} / \mathrm{v}$ ) as solvent system in linear gradient mode from 5 to $100 \%$ over $15 \mathrm{~min}$ at a flow rate of $1.0 \mathrm{~mL} / \mathrm{min}$.

High resolution ESI-MS spectra were recorded using a Bruker MaXis 4G ultrahigh-resolution quadrupole time-of-flight mass spectrometer (McMaster University). Compounds were analyzed on a Dionex 3000 ultimate HPLC system equipped with a multiple wavelength detector, coupled to a Bruker MaXis $4 \mathrm{G}$ ultrahigh-resolution quadrupole time-of-flight mass spectrometer (operating in positive electrospray ionization mode).

Multiple Reaction Monitoring mode (LC-MS/MS) was employed to analyze and quantify griseofulvin in fungal extracts. A griseofulvin standard (Sigma-Aldrich) was used for method development. The precursor ion $(\mathrm{m} / \mathrm{z} 353,[\mathrm{M}+\mathrm{H}]+$, retention time $8.51 \mathrm{~min}$.) was selected for in the first quadrupole; daughter ions were generated at a cone voltage of $40 \mathrm{~V}$ and collision energy of $20 \mathrm{~V}$. The daughter ions monitored were $\mathrm{m} / \mathrm{z} 165$ and $\mathrm{m} / \mathrm{z} 215$. The first 
transition was the most abundant product ion and was used for quantification $(\mathrm{m} / \mathrm{z} 165$, quantifier), whereas the second ion ( $\mathrm{m} / \mathrm{z} 215$, qualifier) was used for confirmation purposes. Quantitative analysis was performed by comparison of the quantifier peak area to that of an external griseofulvin standard using Masslynx V4.0 software.

\subsubsection{NMR}

${ }^{1} \mathrm{H}$ and ${ }^{13} \mathrm{C}$ NMR spectra were measured at 400 and $100 \mathrm{MHz}$ on a Bruker-400 spectrophotometer. Some samples were run on a Bruker AVANCE III $700 \mathrm{MHz}$ spectrophotometer. $\mathrm{CD}_{3} \mathrm{OD}, \mathrm{CD}_{3} \mathrm{CN}, \mathrm{CDCl}_{3}$ or $\mathrm{CD}_{3} \mathrm{COCD}_{3}$ (CDN Isotopes, Pointe-Claire, Quebec) were used as NMR solvents and spectra were referenced to the appropriate solvent peak.

\subsubsection{IR, UV-VIS and OR}

IR (film) spectra were measured using a Varian 1000 FT-IR.

UV-VIS (MeOH) spectra were recorded on a Varian Cary 3 UV-visible spectrophotometer scanning from $190-800 \mathrm{~nm}$.

Optical rotations were determined using an Autopol IV polarimeter (Rudolph Analytical, NJ). 


\subsection{BIOACTIVITY SCREENING OF PURIFIED METABOLITES}

The compounds isolated were tested for antimicrobial activity against Pseudomonas fluorescens (ATCC 12633), Bacillus subtilis (ATCC 23857), and S. cerevisiae, in vitro. Assays were performed in 96-well polystyrene microplates. The bacteria were inoculated and grown in $5 \mathrm{~g} / \mathrm{L}$ yeast extract, $10 \mathrm{~g} / \mathrm{L}$ peptone, and $10 \mathrm{~g} / \mathrm{L} \mathrm{NaCl}$. S. cerevisiae was inoculated and grown in $1 \mathrm{~g} / \mathrm{L}$ yeast extract supplemented with $10 \mathrm{~g} / \mathrm{L}$ glucose. Compounds were individually tested at 50,100 and $500 \mu \mathrm{M}$ in 96-well microplates (Sterile Falcon 353072 Microtest-9, Franklin Lakes, NJ). The compounds were dissolved in DMSO, and a $10 \mu \mathrm{L}$ aliquot of each individual metabolite solution was added to $200 \mu \mathrm{L}$ of bacterial or yeast suspension. Chloramphenicol was the positive control for the bacterial tests and nystatin for the yeast assays; DMSO was the negative control. The assays were performed in triplicate and incubated at $28^{\circ} \mathrm{C}$ on a rotary table shaker, providing gentle agitation $(700 \mathrm{rpm})$. Optical density (OD) measurements were taken hourly at $600 \mathrm{~nm}$ with a Molecular Devices Spectra Max 340PC reader (Sunnyvale, CA, USA) taken hourly. OD data were analyzed by ANOVA followed by Tukey's test for significant differences (Systat V13) compared to the negative control (DMSO). 


\section{RESULTS}

\subsection{SECONDARY METABOLITES OF ENDOPHYTE ISOLATE T5.1B.1 (Xylaria species DAOM 242771)}

Endophyte strain T5.1B.1 was isolated from a surface sterilized pine needle harvested at Deersdale, New Brunswick and identified as a Xylaria species based on its ITS sequence.

An initial screening of the crude extract of the culture indicated the presence of antifungal compounds. The culture was subsequently grown in bulk $(10 \mathrm{~L})$ for metabolite isolation.

Column chromatography was carried out on the crude EtOAc extract. Major fractions were then purified by reverse-phase semi-preparative HPLC. Each major metabolite isolated was structurally characterized using mass spectrometry, NMR, UV, OR. Where possible the data were compared to literature values.

The major metabolites isolated from Xylaria species DAOM 242771 were porric acid C (1), 4-hydroxy-5-(hydroxymethyl)-3-methoxy-6-((3-prenyloxy)isobenzofuran-1(3H)-one (2), (ethyl 3,6-dimethyl-4-prenyloxy)-2-O- $\beta$-D-glucopyranosyl)benzoate (3) and 5,5'- 
[oxybis(methylene)]bis-furfuryl alcohol (4). Additionally, griseofulvin was identified and quantified as a minor metabolites of this strain.

3.1.1. Porric acid C (1):

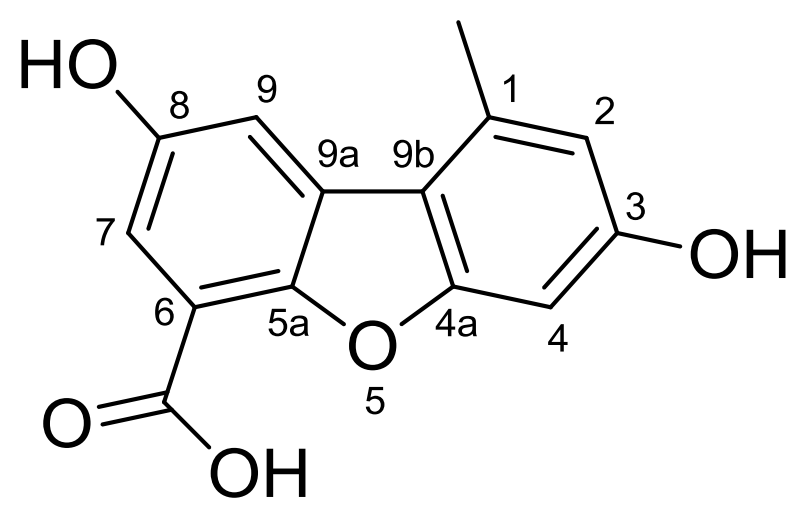

Figure 11: Porric acid C (1) 
Table 1: ${ }^{1} \mathrm{H}$ and $\left(\left(\mathrm{CH}_{3}\right)_{2} \mathrm{CO}, 400 \mathrm{MHz}\right)$ and ${ }^{13} \mathrm{C} \mathrm{NMR}\left(\left(\mathrm{CH}_{3}\right)_{2} \mathrm{CO}, 100 \mathrm{MHz}\right)$ for (1)

\begin{tabular}{|c|c|c|c|c|c|}
\hline Position & $\delta_{\mathrm{C}}$ & $\begin{array}{c}\text { DEPT- } \\
\mathrm{Q} \\
\end{array}$ & $\delta_{\mathrm{H}}(\mathrm{J}, \mathrm{Hz})$ & HMBC & COSY \\
\hline 1 & 110.9 & $\overline{(\mathrm{C})}$ & & & \\
\hline 2 & 118.3 & $(\mathrm{CH})$ & $6.77(\mathrm{~d}, \mathrm{~J}=2.7,1 \mathrm{H})$ & $\mathrm{C}-1$ & $\mathrm{H}-1$ \\
\hline 3 & 159.3 & (C) & & & \\
\hline 4 & 102.6 & $(\mathrm{CH})$ & $6.68(\mathrm{~d}, \mathrm{~J}=2.6 \mathrm{~Hz}, 1 \mathrm{H})$ & & \\
\hline $4 a$ & 139.5 & (C) & & & \\
\hline $5 a$ & 165.7 & (C) & & & \\
\hline 6 & 99.0 & (C) & & & \\
\hline 7 & 101.9 & $(\mathrm{CH})$ & $6.43(\mathrm{~d}, \mathrm{~J}=2.1,1 \mathrm{H})$ & $\mathrm{C}-6, \mathrm{C}-9,6-\underline{\mathrm{COOH}}$ & \\
\hline 8 & 154.2 & (C) & & & \\
\hline 9 & 105.4 & $(\mathrm{CH})$ & 7.34 (br s, $1 \mathrm{H})$ & $\mathrm{C}-6, \mathrm{C}-7, \mathrm{C}-1$ & $\mathrm{H}-7$ \\
\hline $9 a$ & 139.6 & (C) & & & \\
\hline $9 b$ & 110.7 & (C) & & & \\
\hline $1-\mathrm{CH}_{3}$ & 25.7 & $\left(\mathrm{CH}_{3}\right)$ & $2.76(\mathrm{~s}, 3 \mathrm{H})$ & C-1, C-2, C-9a & $\mathrm{H}-2, \mathrm{H}-9$ \\
\hline 6- $\underline{\mathrm{COOH}}$ & 166.4 & (C) & & & \\
\hline 6-COOH & & & $11.94(\mathrm{~s}, 1 \mathrm{H})$ & & \\
\hline $3-\mathrm{OH}$ & & & 9.61 (br s) & & \\
\hline $8-\mathrm{OH}$ & & & & & \\
\hline
\end{tabular}

Compound (1) was isolated as a pale yellow amorphous solid (1.4 mg). The molecular formula $\mathrm{C}_{14} \mathrm{H}_{10} \mathrm{O}_{5}$ was determined based on the molecular ion peak $[\mathrm{M}+\mathrm{H}]^{+}$at $\mathrm{m} / z 258.96$ $\left([\mathrm{M}+\mathrm{H}]^{+}\right.$calcd for $\mathrm{C}_{14} \mathrm{H}_{10} \mathrm{O}_{5}$ 259.05). The UV-VIS spectrum of compound (1) showed absorption maxima at $334,300,289,256$, and $238 \mathrm{~nm}$.

The ${ }^{13} \mathrm{C}$ NMR spectrum displayed fourteen signals; nine quaternary $(\delta 166.4, \delta 165.7, \delta$ $159.3, \delta 154.2, \delta 139.6, \delta 139.5, \delta 110.9, \delta 110.7$, and $\delta 99.0)$, four aromatic methines $(\delta$ $118.3, \delta 105.4,102.6$, and 101.9), and one methyl at $\delta$ 25.7. The ${ }^{1} \mathrm{H}$ NMR spectrum displayed 
seven signals; a sharp singlet at 11.94 suggesting the presence of a carboxylic acid, four aromatic protons at $\delta 7.34(\mathrm{br} \mathrm{s}, 1 \mathrm{H}) \delta 6.77(\mathrm{~d}, J=1.61 \mathrm{~Hz}, 1 \mathrm{H}), \delta 6.68(\mathrm{~d}, J=2.12 \mathrm{~Hz})$, and $\delta 6.43(\mathrm{~d}, J=1.61 \mathrm{~Hz})$, a singlet methyl signal at $\delta 2.76$, and a broad singlet at 9.61 suggestive of a phenol functionality. A carbon signal at $\delta 166.4$ along with the proton at $\delta$ 11.94 is consistent with a carboxylic acid. Both the ${ }^{13} \mathrm{C}$ NMR and ${ }^{1} \mathrm{H}$ NMR suggest the presence of two aromatic rings. The $J$-coupling constants between H-2 (6.77) and H-4 (6.68) indicate a meta-relationship; consistent with a 1,2,4,6-tetrasubstituted ring. Proton H-9 ( $\delta$ 7.34) appears as a broad singlet, however the aromatic proton $\mathrm{H}-7$ appears as a doublet $(J=$ $2.1 \mathrm{~Hz}, 1 \mathrm{H})$ indicating a meta-relationship as well and thus a second 1,2,4,6-tetrasubstituted ring. The unsaturation degree suggests that the two aromatic systems are fused to a central furan, forming a dibenzofuran skeleton. A deshielded quaternary carbon at $\delta 165.7$ is consistent with direct attachment to an oxygen atom, an ipso-carboxylic acid and a parahydroxy group. HMBC correlations from the proton at $\delta 6.43(\mathrm{H}-7)$ to $\mathrm{C}-6$, and the carbonyl at $\delta 166.4$ suggests it is adjacent to C-6. The chemical shift of the aromatic carbon C-6 is shielded $(\delta 99.0)$ and suggests that the aromatic ring is substituted at C-6 by the carboxylic acid group. HMBC correlations between H-7 and the aromatic methine at $\delta 105.4$ (C-9), as well as from H-9 to C-6 suggests they are located on the same aromatic ring. Therefore the remaining two aromatic methines $(\delta 118.3$ and $\delta$ 102.6) are assigned to the second aromatic ring. Due to the meta-relationship already established between the aromatic methines, the 
phenolic carbon at $\delta 154.2$ is assigned as C-8 and the second phenolic carbon at $\delta 159.3$ is assigned as C-3. A methyl group at $\delta 25.7$ showed HMBC correlations to the aromatic carbons at $\delta 136.52, \delta 118.3, \delta 110.9$, and C-9. Based on the chemical shift of these carbons it was determined that they were $\mathrm{C}-9 \mathrm{a}, \mathrm{C}-2$, and $\mathrm{C}-1$ respectively. The remaining oxygenated quaternary carbon at $\delta 139.6$ is assigned as C-5a and the quaternary carbon at $\delta 110.7$ is assigned as C-9b.

A search of the literature revealed that this compound, known as porric acid $\mathrm{C}$ has been reported as a phytochemical of Allium porrum (Garden leek; Carotenuto et al. 1997). Comparison of the ${ }^{1} \mathrm{H}$ and ${ }^{13} \mathrm{C}$ NMR as well as HMBC and COSY correlations shows close agreement. The UV-VIS spectrum was also compared and was in perfect agreement with the literature value (Carotenuto et al. 1997). 
3.1.2. 4-hydroxy-5-(hydroxymethyl)-3-methoxy-6-((3-prenyloxy)isobenzofuran$\underline{1(3 H) \text {-one }(2)}$

OR: $[\alpha]^{25} 2.61\left(\mathrm{c} 0.15, \mathrm{CH}_{3} \mathrm{OH}\right)$

UV-VIS (MeOH): $\lambda_{\max }(\log \varepsilon) 293 \mathrm{~nm}(5.75), 217 \mathrm{~nm}(5.62)$

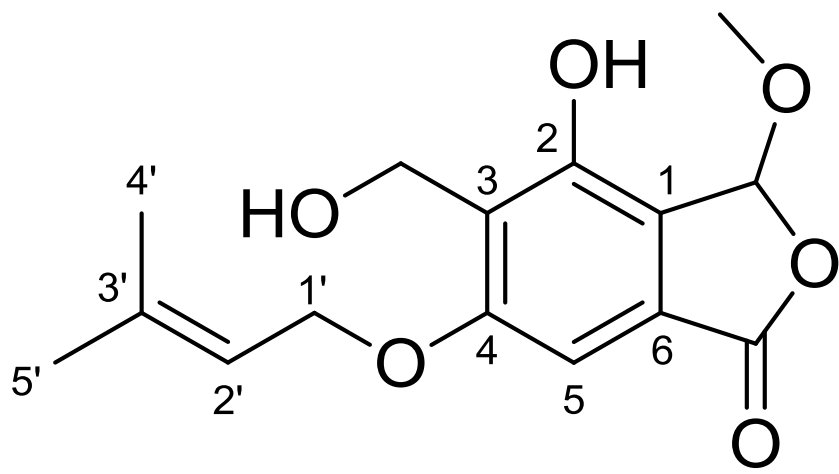

Figure 12: Structure of 4-hydroxy-5-(hydroxymethyl)-3-methoxy-6-((3prenyloxy)isobenzofuran-1(3H)-one (2)

Table 2: ${ }^{1} \mathrm{H}$ and $\left(\left(\mathrm{CH}_{3}\right)_{2} \mathrm{CO}, 700 \mathrm{MHz}\right)$ and ${ }^{13} \mathrm{C}$ NMR $\left(\left(\mathrm{CH}_{3}\right)_{2} \mathrm{CO}, 176 \mathrm{MHz}\right)$ for compound (2)

\begin{tabular}{|c|c|c|c|c|c|}
\hline Position & $\delta_{\mathrm{C}}$ & DEPT-Q & $\delta_{\mathrm{H}}(\mathrm{J}, \mathrm{Hz})$ & HMBC & COSY \\
\hline$\overline{11}$ & 128.8 & (C) & & & \\
\hline 2 & 154.6 & (C) & & & \\
\hline 3 & 120.4 & (C) & & & \\
\hline 4 & 160.1 & (C) & & & \\
\hline 5 & 99.0 & $(\mathrm{CH})$ & $6.87(\mathrm{~s}, 1 \mathrm{H})$ & $\mathrm{C}-3, \mathrm{C}-6,6-\mathrm{CO}$ & \\
\hline 6 & 125.2 & (C) & & & \\
\hline 1 ' & 66.6 & $\left(\mathrm{CH}_{2}\right)$ & $4.68(\mathrm{~d}, \mathrm{~J}=6.48,2 \mathrm{H})$ & C-2', C-3', C-4 & H-2' \\
\hline 2' & 120.5 & $(\mathrm{CH})$ & $5.48(\mathrm{t}, \mathrm{J}=6.48,1 \mathrm{H})$ & & $\mathrm{H}-\mathrm{1}^{\prime}$ \\
\hline 3' & 138.7 & (C) & & & \\
\hline 4 & 18.3 & $\left(\mathrm{CH}_{3}\right)$ & $1.77(\mathrm{~s}, 3 \mathrm{H})$ & C-2', C-3', C-5' & \\
\hline 5 , & 25.8 & $\left(\mathrm{CH}_{3}\right)$ & $1.78(\mathrm{~s}, 3 \mathrm{H})$ & C-2', C-3', C-4' & \\
\hline $1-\mathrm{COCH}_{3} \mathrm{O}$ & 56.0 & $\left(\mathrm{CH}_{3}\right)$ & $3.50(\mathrm{~s}, 3 \mathrm{H})$ & $1-\mathrm{CHOCH}_{3}$ & \\
\hline $1-\mathrm{CHOCH}_{3}$ & 103.0 & $(\mathrm{CH})$ & $6.38(\mathrm{~s}, 1 \mathrm{H})$ & $1-\mathrm{CHOCH}_{3}, 6-\mathrm{CO}$ & \\
\hline $3-\mathrm{CH}_{2}$ & 59.3 & $\left(\mathrm{CH}_{2}\right)$ & $5.01(\mathrm{~s}, 2 \mathrm{H})$ & $\mathrm{C}-2, \mathrm{C}-3, \mathrm{C}-4$ & \\
\hline $6-\mathrm{CO}$ & 168.2 & (C) & & & \\
\hline
\end{tabular}


Compound (2) was isolated as a white amorphous solid (1.5 mg). A molecular formula of $\mathrm{C}_{15} \mathrm{H}_{18} \mathrm{O}_{2}$ (degree of unsaturation equal to seven) was established based on the ion peak $[\mathrm{M}+\mathrm{H}]^{+}$observed at $\mathrm{m} / z 295.09$ (calculated $[\mathrm{M}+\mathrm{H}]^{+}$for $\mathrm{C}_{15} \mathrm{H}_{18} \mathrm{O}_{2} 295.11$ ). The UV spectrum displayed absorption maxima at $217 \mathrm{~nm}$ and $293 \mathrm{~nm}$.

Thirteen carbon signals were observed on the ${ }^{13} \mathrm{C}$ NMR spectrum of compound (2). Based on a DEPT-Q experiment it was possible to assign the carbons as follows; three methine ( $\delta$ $120.5,103.0$, and 99.0), two methylene ( $\delta$ 66.6, and 59.3), three methyl ( $\delta 56.0,25.8$, and $18.3)$, and eight quaternary carbons $(\delta 168.2,160.1,154.6,138.7,128.8,125.2,120.5$, and 120.4). An aromatic hydroxymethyl $(\delta 59.3, \delta 5.01, \mathrm{~s}, 2 \mathrm{H})$ and a methoxy group $(\delta 56.0, \delta$ 3.50, s, 3H) were observed. The methyl groups H-4' and H-5' showed HMBC correlations to the quaternary carbon C-3', the methine C-2', and the oxygenated methylene C-1'. The proton signal of H-1' $(\delta 4.68, \mathrm{~d}, J=6.48 \mathrm{~Hz}, 2 \mathrm{H})$ appears as a doublet, consistent with attachment to C-2', while H-2' appears as a triplet $(\delta 5.48, \mathrm{t}, J=6.48 \mathrm{~Hz}, 1 \mathrm{H})$. COSY correlations were also observed between the methine $\mathrm{H}-2$ ' to $\mathrm{H}-1$ '. This is consistent with a prenyloxy fragment.

The ${ }^{1} \mathrm{H}$ NMR spectrum displayed only one aromatic proton at $\delta 6.87(\mathrm{H}-5 ; \mathrm{s}, 1 \mathrm{H})$, indicating a penta-substituted aromatic ring (accounting for four degrees of unsaturation). An HMBC 
correlation was observed between H-5 and two quaternary aromatic carbons C-3 and C-6, as well as a carbonyl carbon at $\delta 168.2$. The hydroxymethyl protons at $\delta 5.01(\mathrm{~s}, 2 \mathrm{H})$ displayed HMBC correlations to the quaternary aromatic carbons C-3, C-2, and C-4. A cross peak was observed between H-1' and C-4. These observations indicate the hydroxymethyl group was located at C-3, the prenyloxy at C-4 and an hydroxyl group at C-2. An HMBC correlation between the acetal proton at $\delta 6.38$ and the carbonyl at $\delta 168.2$ that was already shown to correlate to C-5 indicates the presence of a second ring structure; accounting for the remaining two degrees of unsaturation. Since H-5 was observed to have a correlation to C-6 and the carbonyl it is determined that C-6 is the location of substitution of the carbonyl and therefore $\mathrm{C}-1$ is assigned as $\delta$ 128.8. Compound (2) is therefore 4-hydroxy-5(hydroxymethyl)-3-methoxy-6-((3-prenyloxy)isobenzofuran-1(3H)-one. 
OR: $[\alpha]^{25} 18.75\left(\mathrm{c} 0.16, \mathrm{CH}_{3} \mathrm{OH}\right)$

UV-VIS (MeOH): $\lambda_{\max }(\log \varepsilon) 249 \mathrm{~nm}(5.84), 218 \mathrm{~nm}$ (5.78)

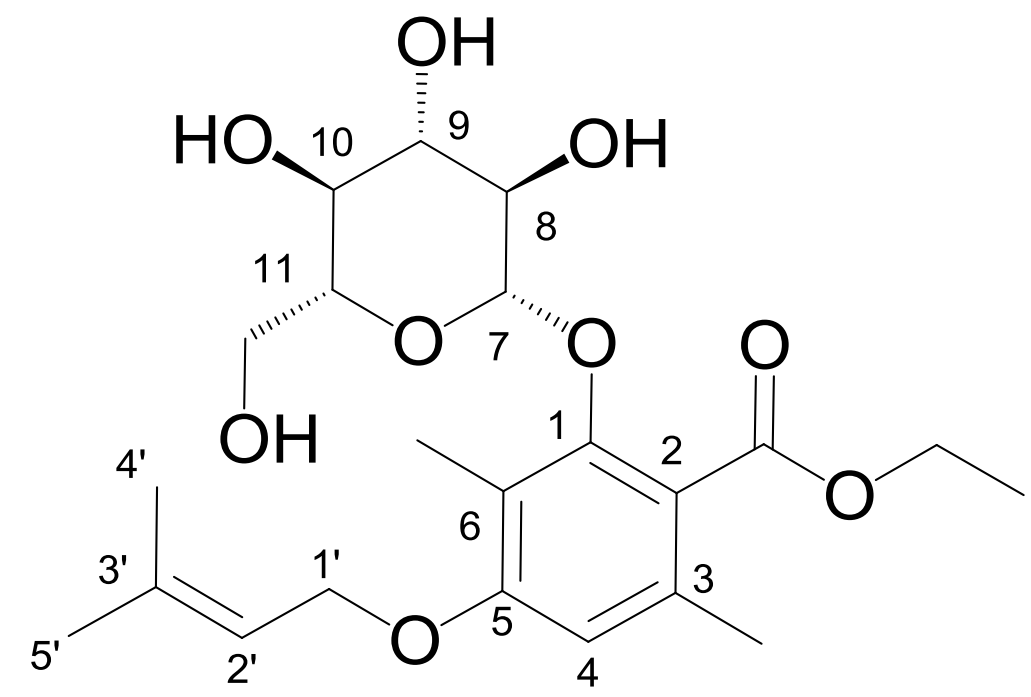

Figure 13: Structure of [(ethyl 3,6-dimethyl-4-prenyloxy)-2-O- $\beta$-D-glucopyranosyl)benzoate] (3). 
Table 3: ${ }^{1} \mathrm{H}$ and $\left(\left(\mathrm{CH}_{3}\right)_{2} \mathrm{CO}, 700 \mathrm{MHz}\right)$ and ${ }^{13} \mathrm{C} \mathrm{NMR}\left(\left(\mathrm{CH}_{3}\right)_{2} \mathrm{CO}, 176 \mathrm{MHz}\right)$ of compound (3)

\begin{tabular}{|c|c|c|c|c|c|}
\hline Position & $\delta_{\mathrm{C}}$ & $\begin{array}{c}\text { DEPT- } \\
\text { Q }\end{array}$ & $\begin{array}{c}\delta_{\mathrm{H}} \\
(\mathrm{J}, \mathrm{Hz})\end{array}$ & HMBC & COSY \\
\hline 1 & 153.8 & (C) & & & \\
\hline 2 & 123.5 & (C) & & & \\
\hline 3 & 135.5 & (C) & & & \\
\hline 4 & 110.8 & $(\mathrm{CH})$ & $6.72(\mathrm{~s}, 1 \mathrm{H})$ & $3-\mathrm{CH}_{3}, \mathrm{C}-2, \mathrm{C}-6$ & \\
\hline 5 & 159.6 & (C) & & & \\
\hline 6 & 118.7 & (C) & & & \\
\hline 7 & 105.3 & $(\mathrm{CH})$ & $4.49(\mathrm{~d}, 7.1,1 \mathrm{H})$ & $\mathrm{C}-1$ & H-8/H-9 \\
\hline 8 & 75.3 & $(\mathrm{CH})$ & $3.43(\mathrm{~m}, 2 \mathrm{H}) \mathrm{o}$ & C-9 & H-10 \\
\hline 9 & 77.6 & $(\mathrm{CH})$ & $3.43(\mathrm{~m}, 2 \mathrm{H}) \mathrm{o}$ & C-9 & H-10 \\
\hline 10 & 71.9 & $(\mathrm{CH})$ & $3.26(\mathrm{~m}, 1 \mathrm{H})$ & C-9 & H-8/H-9 \\
\hline 11 & 77.5 & $(\mathrm{CH})$ & $3.18(\mathrm{~m}, 1 \mathrm{H})$ & $\mathrm{C}-10$ & \\
\hline 1 ' & 66.1 & $\left(\mathrm{CH}_{2}\right)$ & $\begin{array}{c}4.61(\mathrm{~d}, 6.30 \\
2 \mathrm{H})\end{array}$ & C-2', C-3', C-5 & H-4', H-5' \\
\hline 2 ' & 120.9 & $(\mathrm{CH})$ & $5.50(\mathrm{~m}, 1 \mathrm{H})$ & C-4', C-5' & H-1' \\
\hline 3 & 138.0 & (C) & & & \\
\hline $4^{\prime}$ & 18.3 & $\left(\mathrm{CH}_{3}\right)$ & $1.79(\mathrm{~d}, 6 \mathrm{H}) \mathrm{o}$ & C-2', C-3', C-5' & H-1', H-2' \\
\hline 5 & 25.8 & $\left(\mathrm{CH}_{3}\right)$ & $1.79(\mathrm{~d}, 6 \mathrm{H}) \mathrm{o}$ & C-3', C-4', C-5' & H-1', H-2' \\
\hline 2- $\mathrm{COOCH}_{2} \underline{\mathrm{CH}}_{3}$ & 14.4 & $\left(\mathrm{CH}_{3}\right)$ & $1.34(\mathrm{t}, 7.1,3 \mathrm{H})$ & 2- $\mathrm{COOCH}_{2} \mathrm{CH}_{3}$ & 2- $\mathrm{COOCH}_{2} \mathrm{CH}_{3}$ \\
\hline 2- $\mathrm{COOCH}_{2} \underline{\mathrm{CH}}_{3}$ & 61.6 & $\left(\mathrm{CH}_{2}\right)$ & $\begin{array}{l}4.23(\mathrm{~m}, 1 \mathrm{H}) \\
4.36(\mathrm{~m}, 1 \mathrm{H})\end{array}$ & $\begin{array}{l}2-\mathrm{COOCH}_{2} \underline{\mathrm{CH}}_{3}, \\
2-\underline{\mathrm{COOCH}}{ }_{2} \mathrm{CH}_{3}\end{array}$ & 2- $\mathrm{COOCH}_{2} \underline{\mathrm{CH}}_{3}$ \\
\hline $2-\underline{\mathrm{COOCH}_{2} \mathrm{CH}_{3}}$ & 170.4 & (C) & & & \\
\hline $6-\mathrm{CH}_{3}$ & 9.3 & $\left(\mathrm{CH}_{3}\right)$ & $2.18(\mathrm{~s}, 3 \mathrm{H})$ & C-1, C-5, C6 & \\
\hline $3-\mathrm{CH}_{3}$ & 20.1 & $\left(\mathrm{CH}_{3}\right)$ & $2.29(\mathrm{~s}, 3 \mathrm{H})$ & C-2, C-3, C-4 & $\mathrm{H}-4$ \\
\hline $11-\mathrm{CH}_{2}$ & 63.3 & $\left(\mathrm{CH}_{2}\right)$ & $\begin{array}{l}3.54(\mathrm{~m}, 1 \mathrm{H}) \\
3.73(\mathrm{~m}, 1 \mathrm{H})\end{array}$ & & $\begin{array}{l}\mathrm{H}-11,11-\mathrm{OH} \\
\mathrm{H}-11,11-\mathrm{OH}\end{array}$ \\
\hline $11-\mathrm{OH}$ & & & $3.29(\mathrm{~m}, 0.5 \mathrm{H})$ & & H-11 \\
\hline
\end{tabular}

Compound (3) was isolated as a white amorphous solid (2.4 mg). A molecular formula of $\mathrm{C}_{22} \mathrm{H}_{32} \mathrm{O}_{9}$, and thus a degree of unsaturation equal to seven was established based on the ion peak $[\mathrm{M}+\mathrm{H}]^{+}$observed at $\mathrm{m} / z 441.13$ (calculated $[\mathrm{M}+\mathrm{H}]^{+}$for $\mathrm{C}_{22} \mathrm{H}_{32} \mathrm{O}_{9} 441.2080$ ). The mass spectrum displayed another significant peak at $\mathrm{m} / \mathrm{z} 279.05$, suggesting the loss of 162 Daltons from the parent ion, indicating the presence of a hexose unit attached to an aglycone moiety. 
The UV spectrum displayed absorption maxima at $218 \mathrm{~nm}$ and $249 \mathrm{~nm}$. Absorption at $249 \mathrm{~nm}$ may indicate the presence of an aromatic ring substituted with electron-withdrawing substituents such an alkyl ester (Pavia et al. 2009).

Thirteen carbon signals were observed on the ${ }^{13} \mathrm{C}$ NMR spectrum of compound (3). Based on a DEPT-Q experiment it was possible to assign the carbons as follows; seven methine ( $\delta$ $120.9,110.8,105.3,77.6,77.5,75.3$, and 71.9$)$, three methylene ( $\delta 66.1,63.3$, and 61.6$)$, three methyl $(\delta 25.8,20.1,18.3,14.4$, and 9.3), and seven quaternary carbons. The methyl groups C-4' and C-5' showed HMBC correlations to the quaternary carbon C-3', the methine C-2', and the oxygenated methylene $\mathrm{C}-1^{\prime}$. The proton signal of $\mathrm{H}-1^{\prime}(\delta 4.61, \mathrm{~d}, J=6.30 \mathrm{~Hz}, 2 \mathrm{H})$ appears as a doublet, consistent with attachment to C-2', while H-2' appears as a multiplet ( $\delta$ 5.50, $\mathrm{m}, 1 \mathrm{H})$. COSY correlations were observed between the methylene $\mathrm{H}-1$ ' and $\mathrm{H}-2$ ', as well as H-4' and H-5' - establishing a prenyloxy fragment.

The aromatic region of the ${ }^{1} \mathrm{H}$ NMR spectrum of compound (3) revealed one singlet aromatic proton at $\delta 6.72(\mathrm{H}-4)$, indicating the presence of a penta-substituted aromatic ring. The methyl group protons at $\delta 2.29\left(3-\mathrm{CH}_{3}\right)$ displayed $\mathrm{HMBC}$ correlations to $\mathrm{C}-2, \mathrm{C}-3$ and $\mathrm{C}-4$ while, H-4 showed HMBC correlations to the methyl group 3- $\mathrm{CH}_{3}, \mathrm{C}-2$, and C-6; indicating 
that the methyl group is substituted at $\mathrm{C}-3$. Another methyl group at $\delta 2.18\left(6-\mathrm{CH}_{3}\right)$ displayed HMBC correlations to C-6, C-5, and C-1 indicating it is also substituent of the aromatic ring and substituted at C-6.

Four oxygenated methines and an acetal were observed at $\delta 77.6, \delta 77.5, \delta 75.3, \delta 71.9$, and $\delta$ 105.3 respectively; consistent with a hexose unit. The doublet of the anomeric proton $\mathrm{H}-7$ at $\delta$ 4.49 has a coupling constant of $7.1 \mathrm{~Hz}$, indicating a $\beta$-linked glucopyranosyl moiety. Compound (3) is therefore assigned as [(ethyl 3,6-dimethyl-4-prenyloxy)-2-O- $\beta$-Dglucopyranosyl)benzoate].

\subsubsection{5,5'-[oxybis(methylene)]bis-furfuryl alcohol (4)}

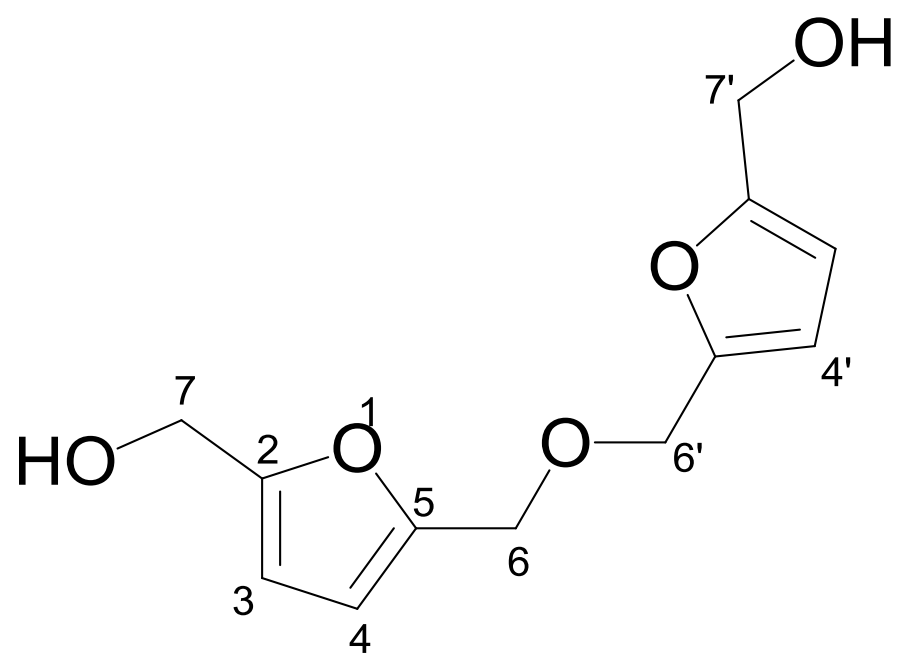

Figure 14: Structure of 5,5'-[oxybis(methylene)]bis-furfuryl alcohol (4). 
Table 4: ${ }^{1} \mathrm{H}$ and $\left(\left(\mathrm{CH}_{3}\right)_{2} \mathrm{CO}, 700 \mathrm{MHz}\right)$ and ${ }^{13} \mathrm{C} \mathrm{NMR}\left(\left(\mathrm{CH}_{3}\right)_{2} \mathrm{CO}, 176 \mathrm{MHz}\right)$ for compound (4)

\begin{tabular}{ccccc}
\hline \hline Position* & $\delta_{\mathrm{C}}$ & DEPT-Q & $\delta_{\mathrm{H}}(\mathrm{J}, \mathrm{Hz})$ & HMBC \\
\hline \hline 2 & 156.8 & $(\mathrm{C})$ & & \\
3 & 108.3 & $(\mathrm{CH})$ & $6.22(\mathrm{~d}, 2.7,2 \mathrm{H})$ & $\mathrm{C}-4, \mathrm{C}-5, \mathrm{C}-2$ \\
4 & 111.0 & $(\mathrm{CH})$ & $6.32(\mathrm{~d}, 2.8,2 \mathrm{H})$ & $\mathrm{C}-3, \mathrm{C}-5, \mathrm{C}-2$ \\
5 & 152.1 & $(\mathrm{C})$ & & \\
6 & 64.1 & $\left(\mathrm{CH}_{2}\right)$ & $4.42(\mathrm{~s}, 4 \mathrm{H})$ & $\mathrm{C}-6, \mathrm{C}-4, \mathrm{C}-5$ \\
7 & 57.3 & $\left(\mathrm{CH}_{2}\right)$ & $4.50(\mathrm{~s}, 4 \mathrm{H})$ & $\mathrm{C}-6, \mathrm{C}-3, \mathrm{C}-2$
\end{tabular}

* carbons and protons associated with positions $2^{\prime}-7^{\prime}$ of Figure 14 are equivalent to the 2-7 positions shown.

Compound (4) was isolated as an amorphous colourless solid (0.4 mg). A molecular formula of $\mathrm{C}_{12} \mathrm{H}_{14} \mathrm{O}_{5}$ was assigned to 4 based on the ion peak observed at $m / z 221.04\left[\mathrm{M}+\mathrm{H}-\mathrm{H}_{2} \mathrm{O}\right]^{+}$in combination with ${ }^{13} \mathrm{C}$ NMR spectral data.

Both the ${ }^{13} \mathrm{C}$ and ${ }^{1} \mathrm{H}$ NMR spectra of 4 indicate a symmetric compound suggesting the chemical possesses a dimeric framework. The ${ }^{13} \mathrm{C}$ NMR spectrum displayed six signals including two oxygenated quaternary carbons at $\delta 156.8$ and $\delta 152.1$, two methines at $\delta 111.0$ and $\delta 108.3$, and two oxymethylenes at $\delta 64.1$ and $\delta$ 57.3. The ${ }^{1} \mathrm{H}$ NMR spectrum displayed four signals integrating for fourteen protons consistent with the molecular formula.

These data suggested the monomer of $\mathbf{4}$ is closely related to a furfuryl alcohol substituted with an hydroxymethyl moiety. This observation was supported by the COSY correlation observed between H-3 $(\delta 6.22, J=2.7 \mathrm{~Hz})$ and $\mathrm{H}-4(\delta 6.32, J=2.8 \mathrm{~Hz})$, and HMBC correlation 
between H-3 to C-2 ( $\delta 156.8)$, C-4 $(\delta 111.0)$ and C-5 ( $\delta 152.1)$; and H4 to C-2 ( $\delta 156.8)$, C-3

( $\delta$ 108.3) and C-5 ( $\delta$ 152.1). Based on the molecular weight it was established that the 5hydroxymethylfurfuryl alcohol ring system was repeated and bridged at C-5 to form the ether bond. Compound 4 is assigned as 5,5'-[oxybis(methylene)]bis-furfuryl alcohol. This compound is well known and synthesized as a starting material in the synthesis of fullerenes and cyclic polyethers. The spectroscopic data were consistent with the literature (Timko et al. 1977).

\subsubsection{ANTIMICROBIAL ASSAYS}

Compounds 1-3 were tested for in vitro antimicrobial activity against $P$. fluorescens (ATCC 12633), B. subtilis (ATCC 23857), and S. cerevisiae using the 96-well microplate technique described by Sumarah et al. (2011). Antimicrobial OD data were analyzed by ANOVA followed by Tukey's test for significant differences (Systat V13) compared to the negative control (DMSO). 


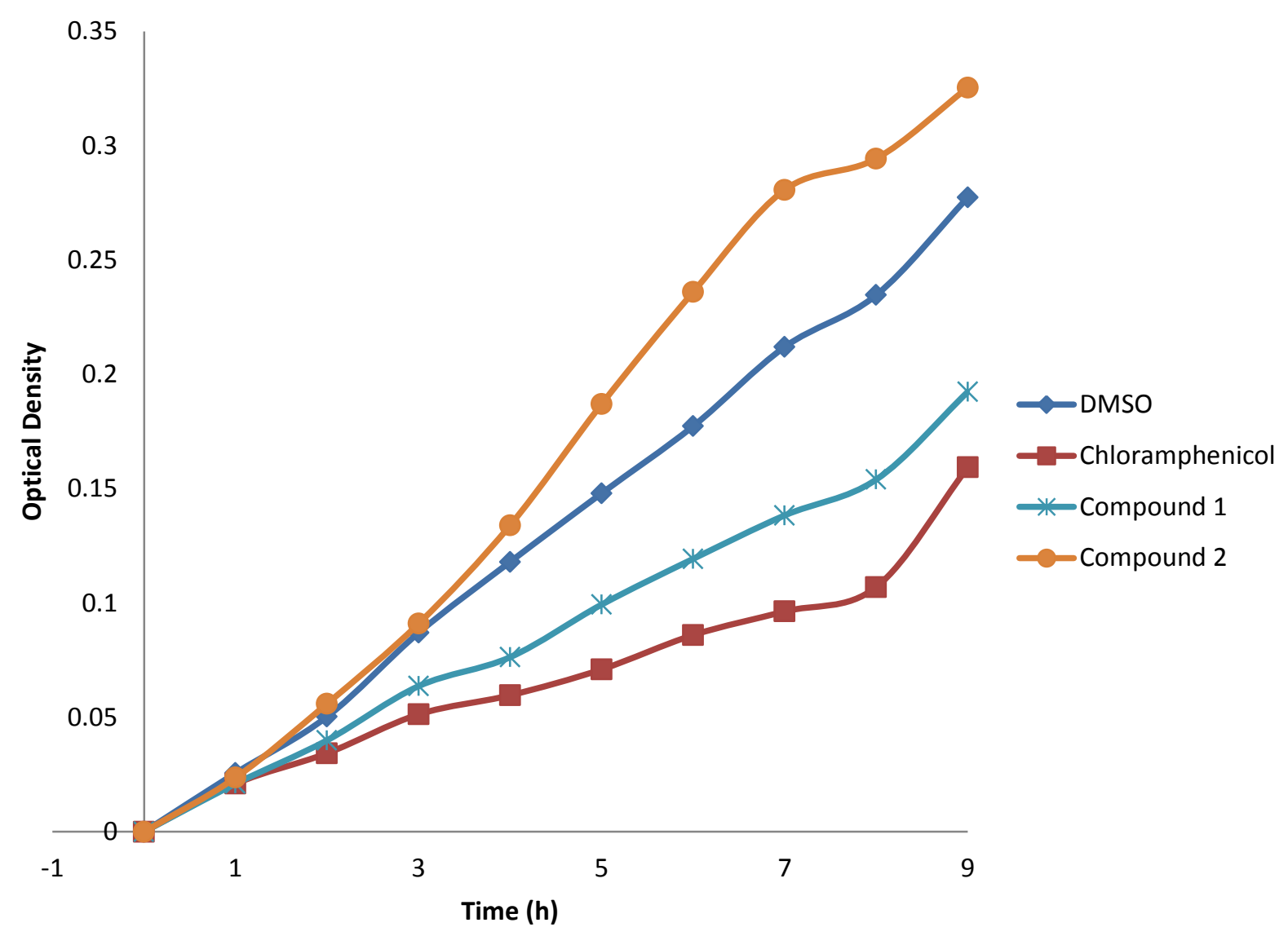

Figure 15: Effect of compounds 1-2 at $100 \mu \mathrm{M}$ on cell growth of $B$. subtilis. 


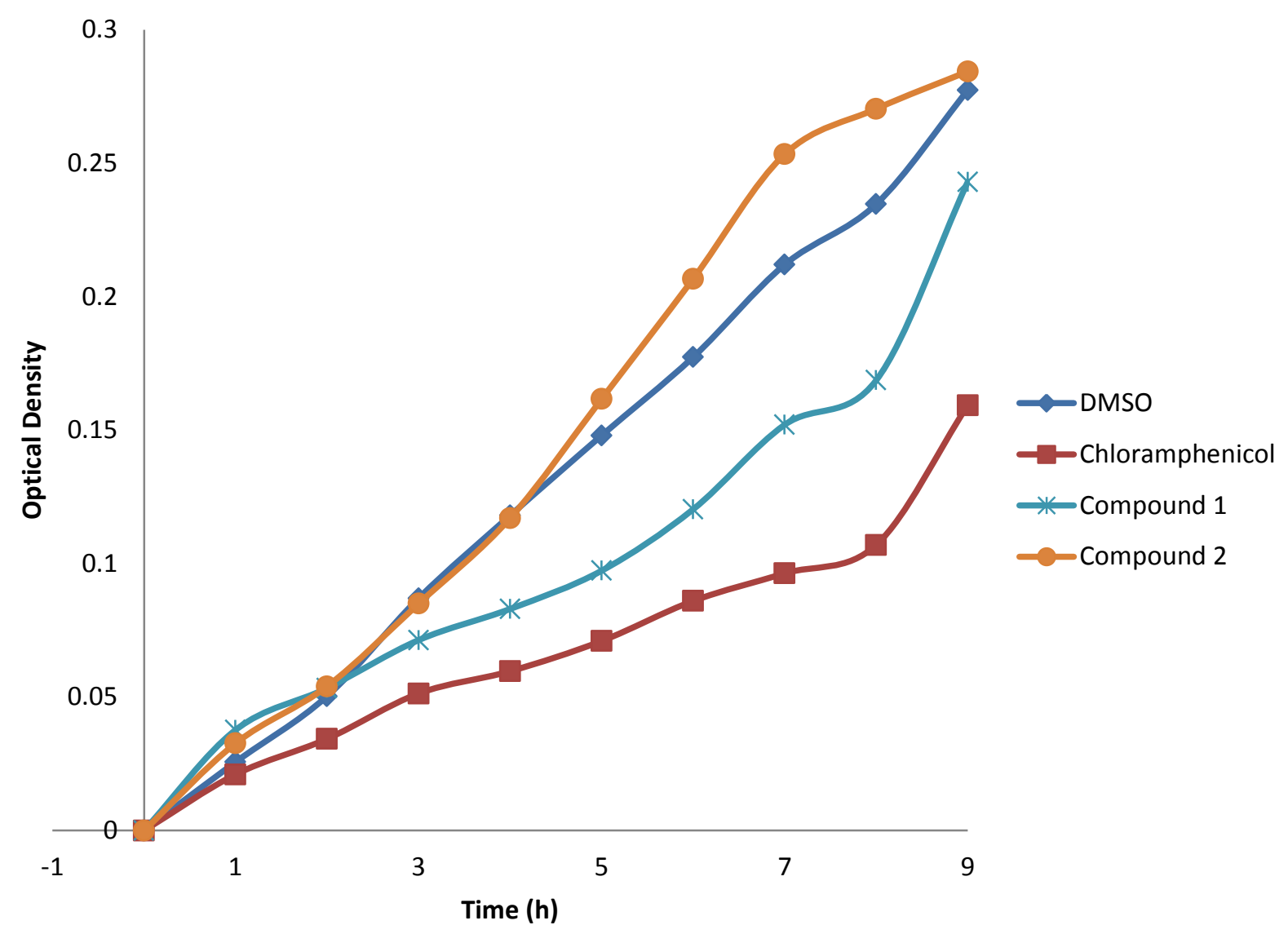

Figure 16: Effect of compounds 1-2 at $500 \mu \mathrm{M}$ on cell growth of B. subtilis.

Compound 1 significantly inhibited growth of B. subtilis at a concentration of $100 \mu \mathrm{M}$ and above $(p=0.003)$. 


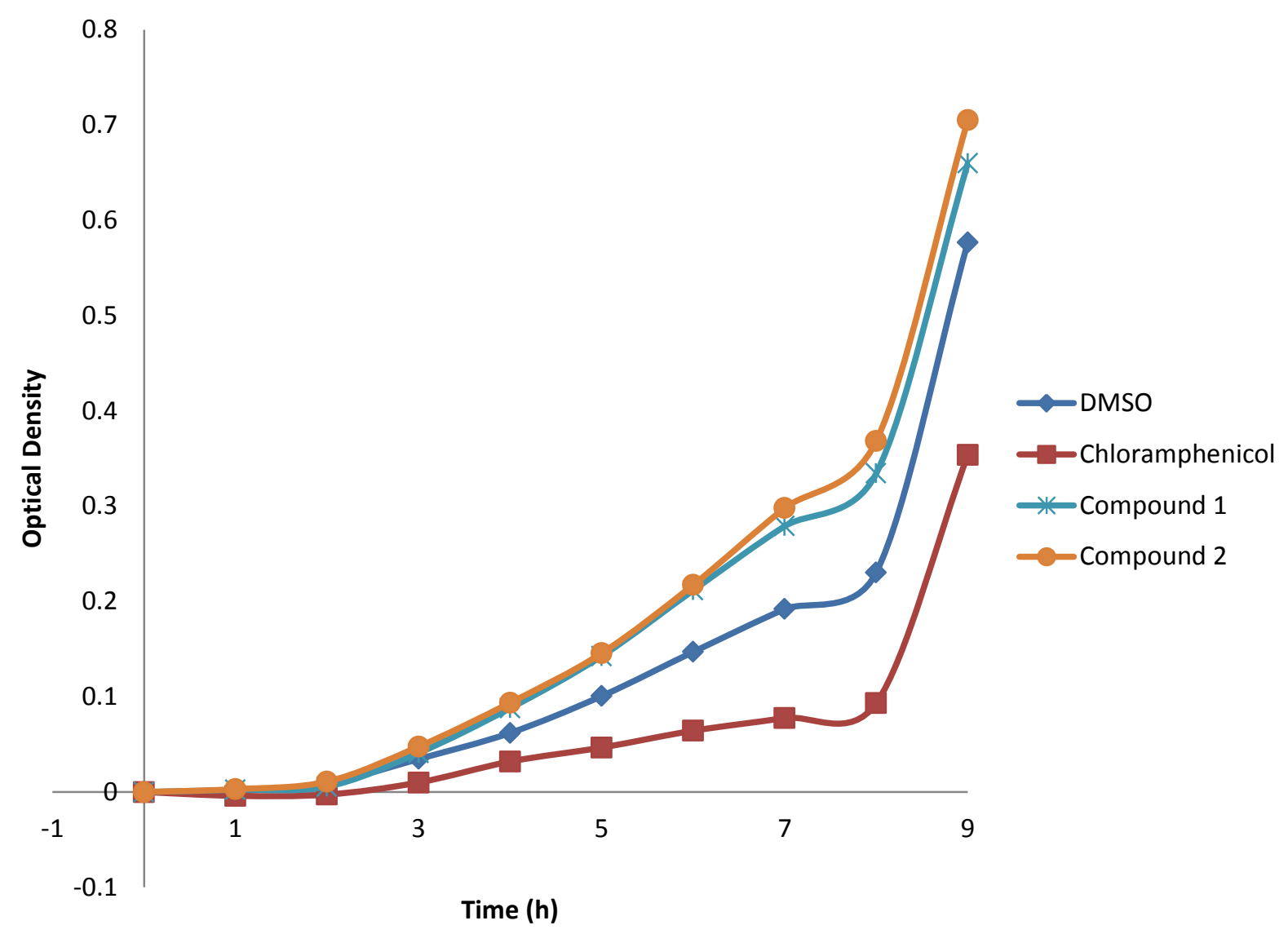

Figure 17: Effect of compounds 1-2 at $100 \mu \mathrm{M}$ on cell growth of $P$. fluorescens. 


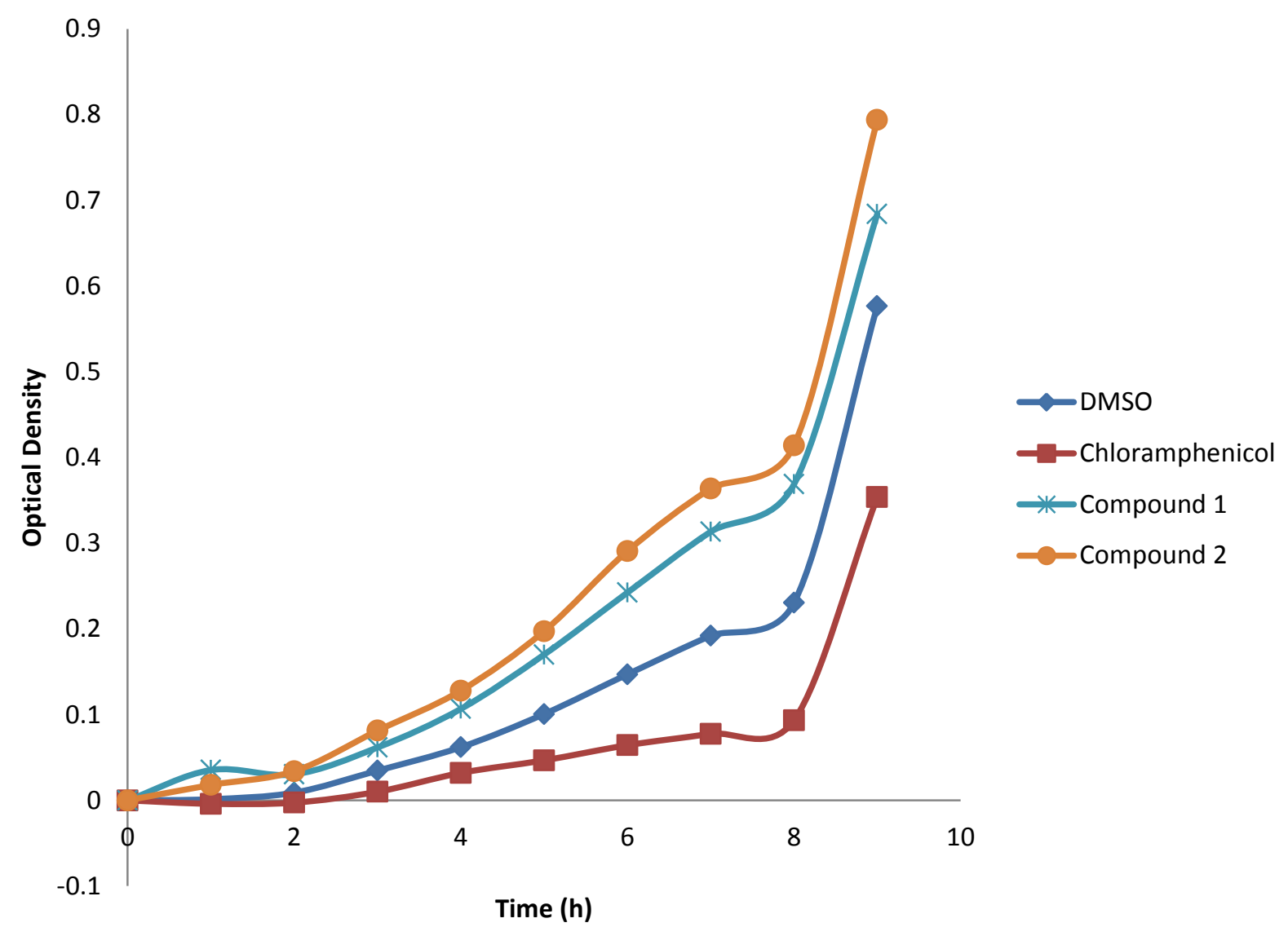

Figure 18: Effect of compounds 1-2 at $500 \mu \mathrm{M}$ on cell growth of $P$. fluorescens.

Neither compound 1 nor $\mathbf{2}$ inhibited growth of $P$. fluorescens up to concentrations of $500 \mu \mathrm{M}$. 


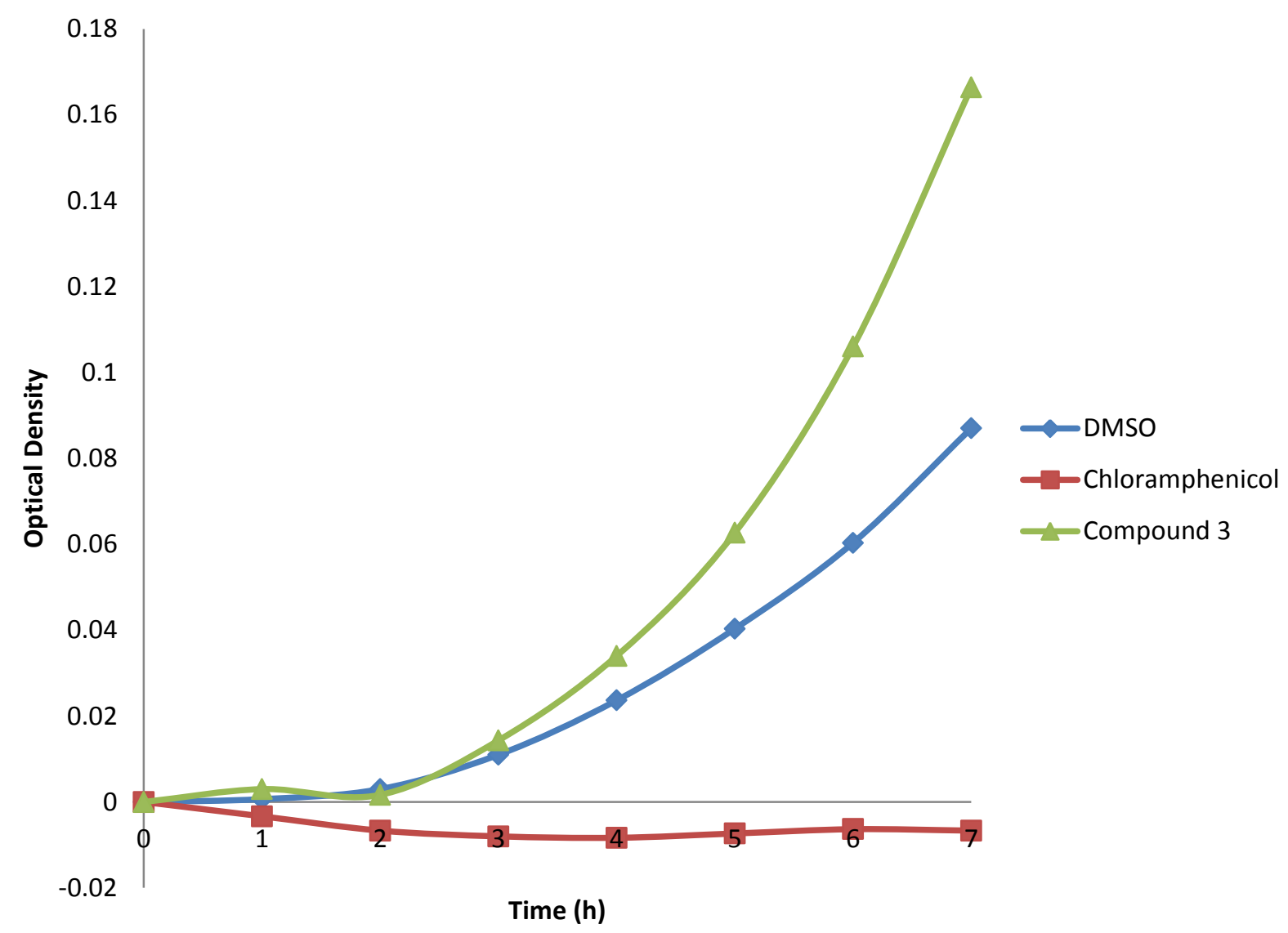

Figure 19: Effect of compound $\mathbf{3}$ at $100 \mu \mathrm{M}$ on cell growth of $P$. fluorescens. 


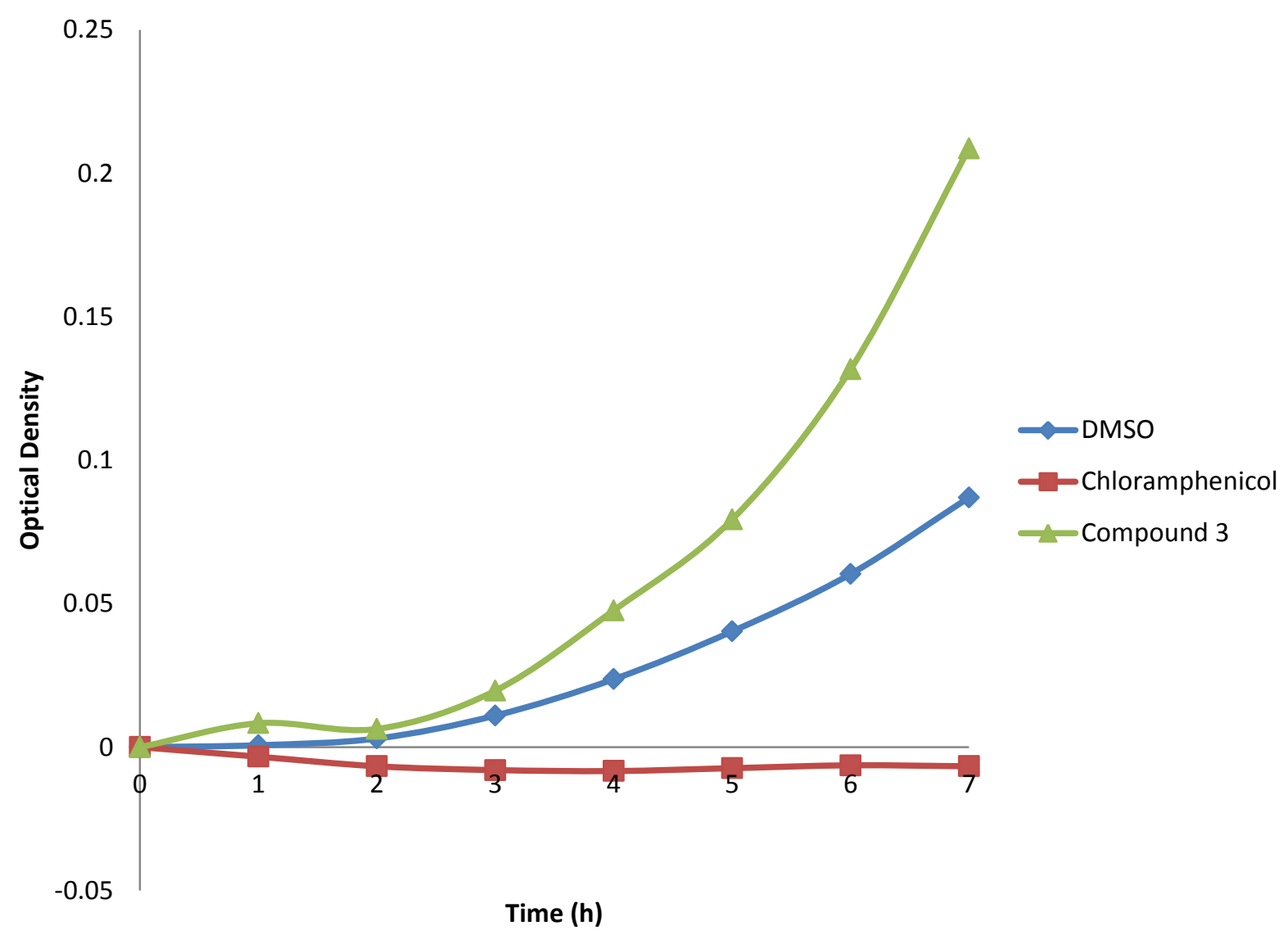

Figure 20: Effect of compound 3 at $500 \mu \mathrm{M}$ on cell growth of $P$. fluorescens.

Compound 3 did not inhibit growth of P. fluorescens at concentrations up to $500 \mu \mathrm{M}$. 


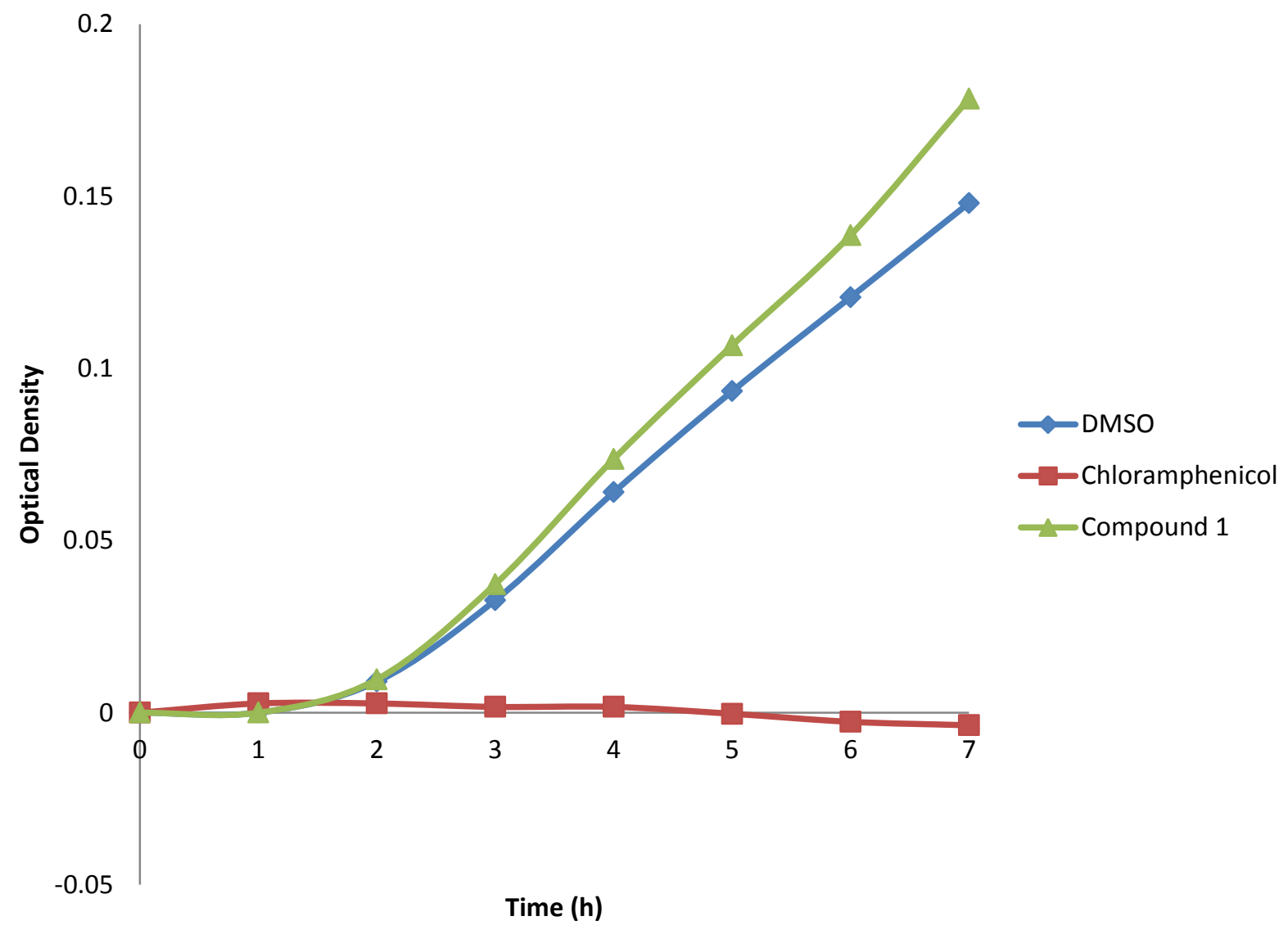

Figure 21: Effect of compound 3 at $100 \mu \mathrm{M}$ on cell growth of B. subtilis. 


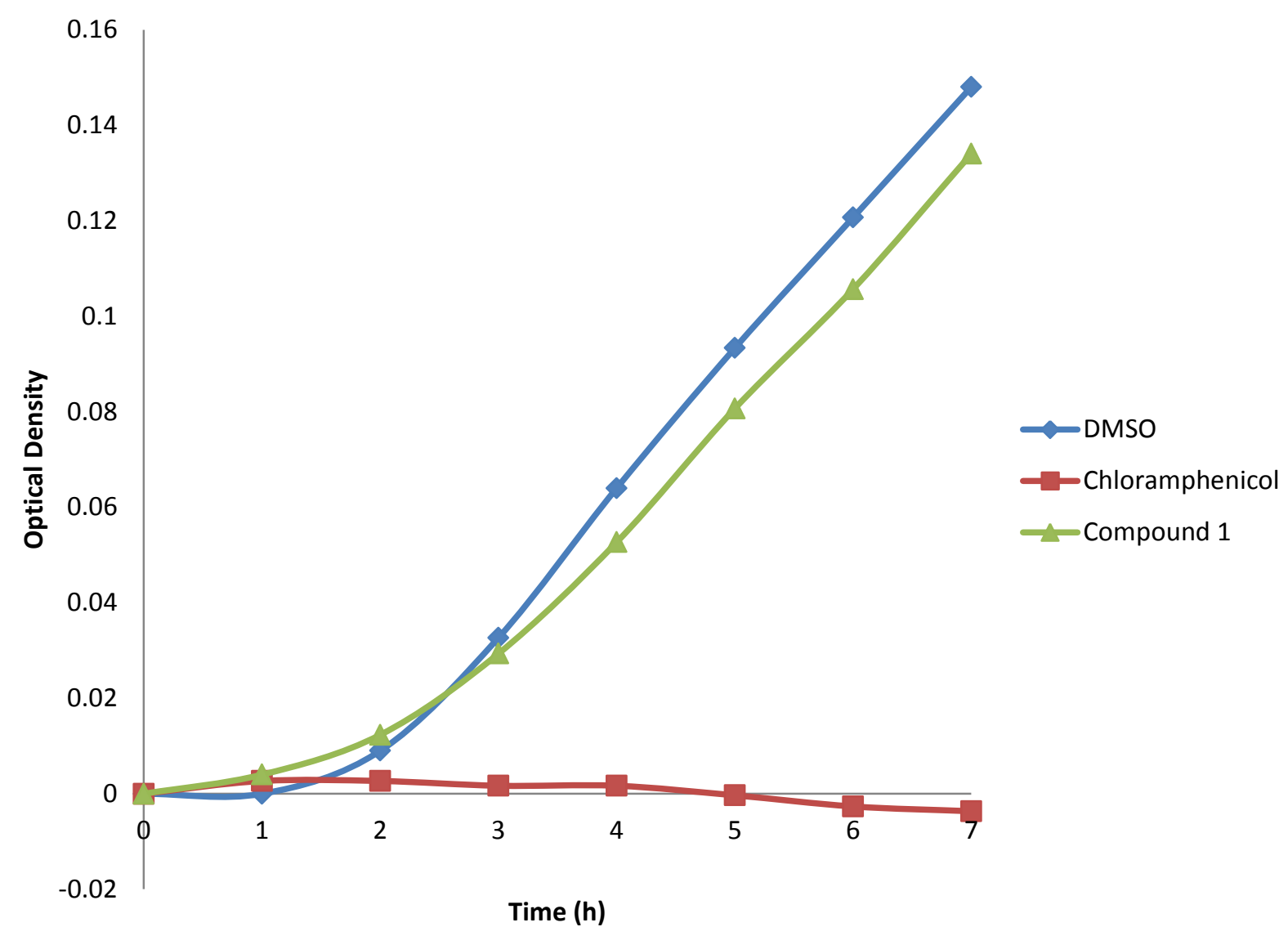

Figure 22: Effect of compound 3 at $500 \mu \mathrm{M}$ on cell growth of B. subtilis.

Compound 3 did not inhibit growth of $B$. subtilis at concentrations up to $500 \mu \mathrm{M}$. 


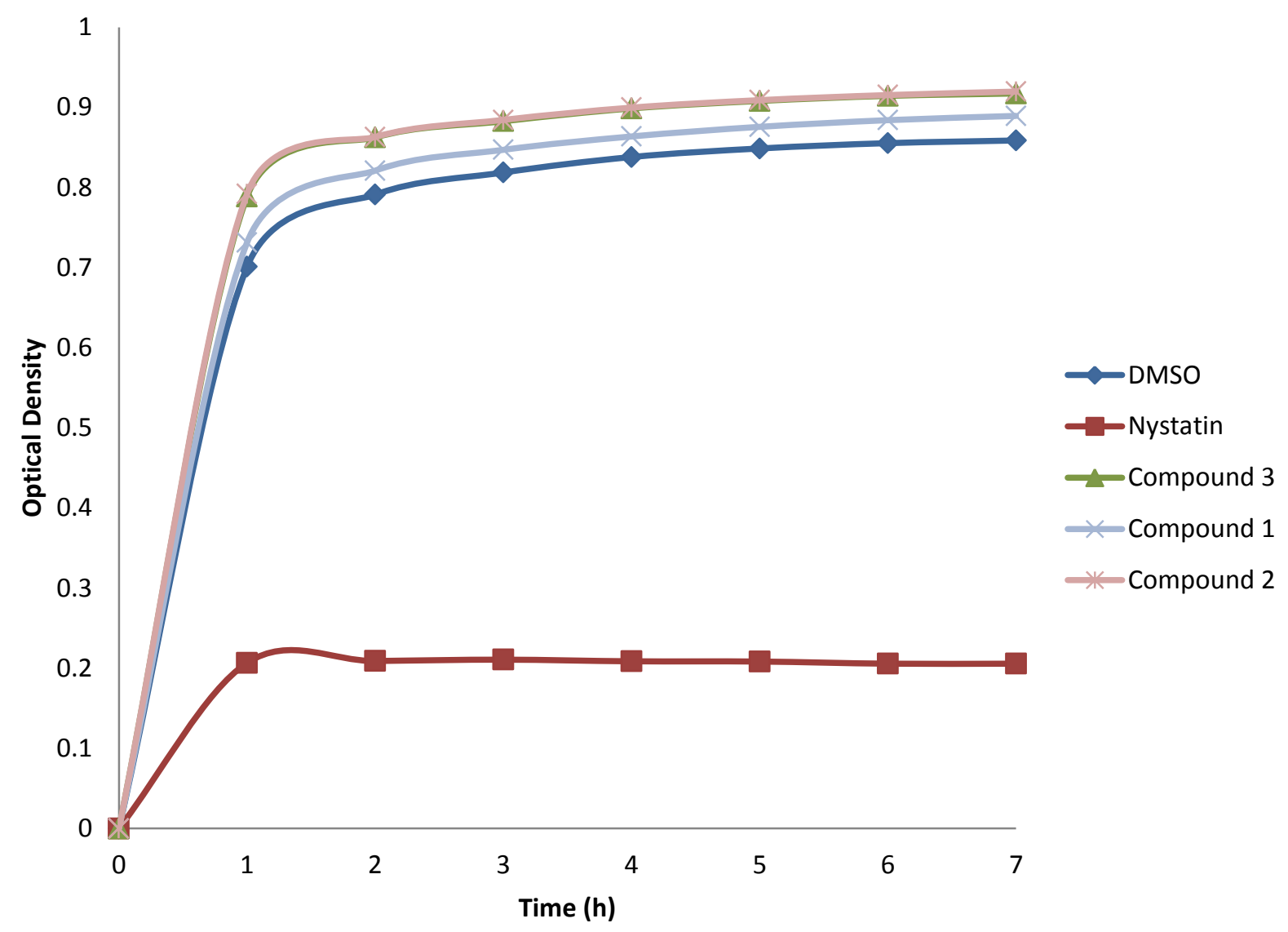

Figure 23: Effect of compounds 1-3 at $100 \mu \mathrm{M}$ on cell growth of S. cerevisiae. 


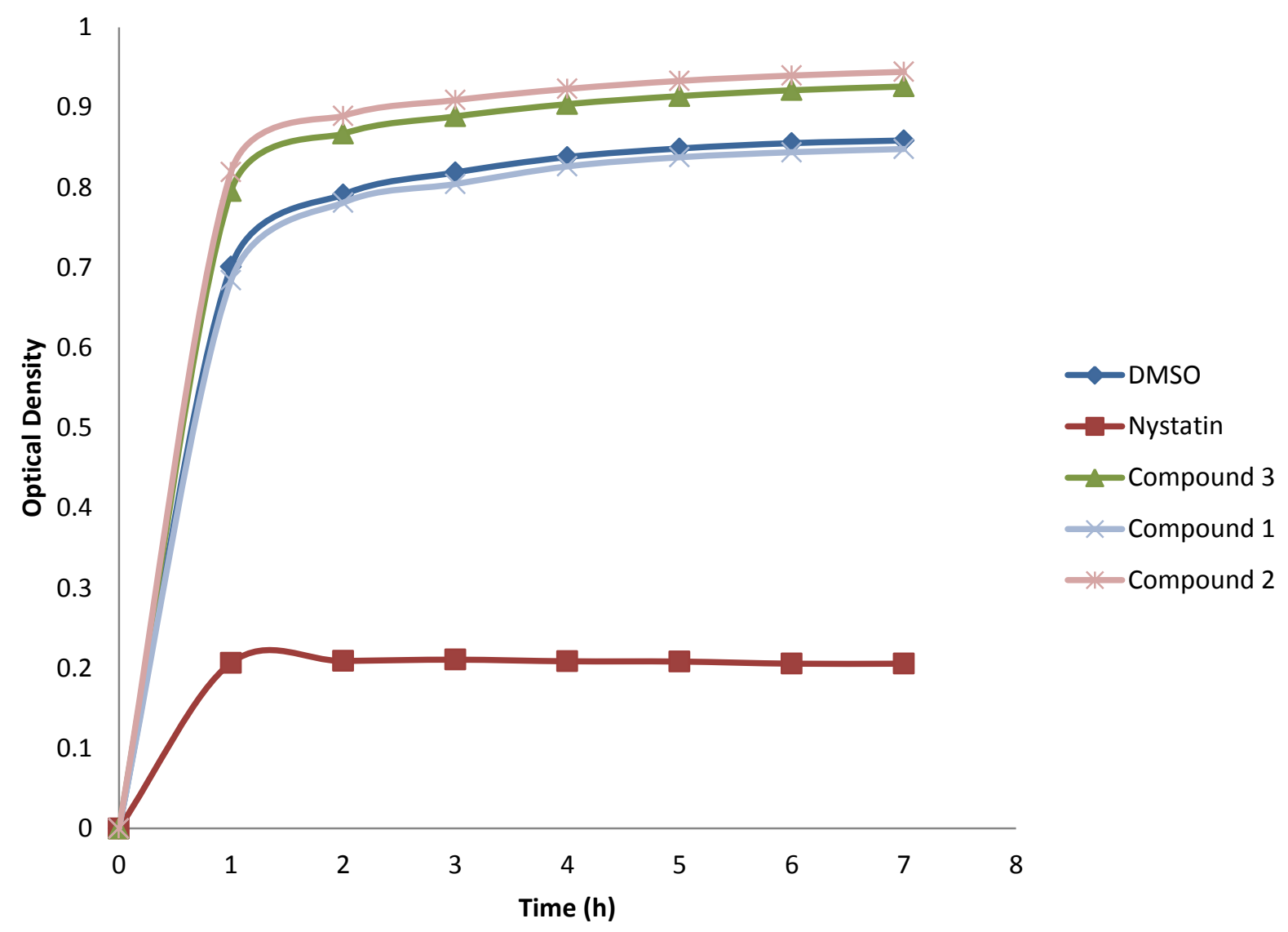

Figure 24: Effect of compounds 1-3 at $500 \mu \mathrm{M}$ on cell growth of $S$. cerevisiae

Compounds 1-3 did not exhibit any growth inhibition on $S$. cerevisiae at concentrations up to $500 \mu \mathrm{M}$. 


\subsection{SECONDARY METABOLITES OF ENDOPHYTE ISOLATE SG-6 AND SG-15}

(UNIDENTIFIED Dothidiomycete, DAOM 242779 AND DAOM 242780)

The crude extract of isolate SG-6 was displayed strong antifungal activity against both $S$. cerevisiae and $M$. violaceum. The inhibition zone using the modified Oxford disc diffusion assay was greater than nystatin at $2 \mathrm{mg} / \mathrm{mL}$ (approximately $1 \mathrm{~cm}$ ). It was therefore chosen for further study.

Flash chromatography of the crude EtOAc extract followed by reverse-phase semi-preparative HPLC led to the isolation of six major metabolites; (R)-2-methyl-2,3-dihydrobenzofuran-4carboxylic acid (5), (R)-6-hydroxy-2-methyl-2,3-dihydrobenzofuran-4-carboxylic acid (6), (R)-5,7-dichloro-6-hydroxy-2-methyl-2,3-dihydrobenzofuran-4-carboxylic acid (7), (R)-5,7dichloro-6-methoxy-2-methyl-2,3-dihydrobenzofuran-4-carboxylic $\quad$ acid $\quad$ (8), 4(methoxymethyl)-2-7-dimethyl-9H-xanthene (9), and 6-ethylidenecyclohex-4-ene-1,2,3-triol (10). 


\subsection{1. (R)-2-methyl-2,3-dihydrobenzofuran-4-carboxylic acid (5)}

OR: $[\alpha]_{D}^{25}-2.1\left(\mathrm{c} 0.27, \mathrm{CH}_{3} \mathrm{OH}\right),[\alpha]_{\mathrm{D}}^{25} 54.1\left(\mathrm{c} 1.1, \mathrm{CH}_{2} \mathrm{Cl}_{2}\right)$

UV-VIS (MeOH): $\lambda_{\max }(\log \varepsilon) 217 \mathrm{~nm}(2.68)$

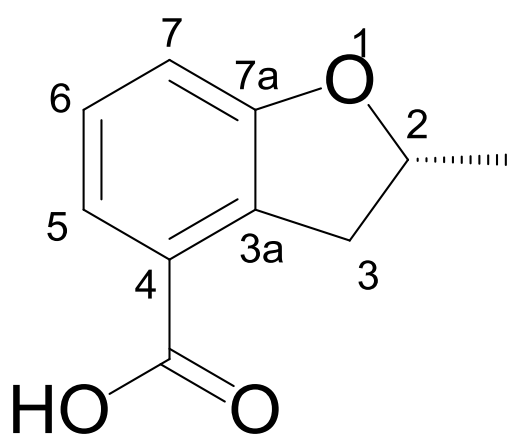

Figure 25: Structure of (R)-2-methyl-2,3-dihydrobenzofuran-4-carboxylic acid (5).

Table 5: ${ }^{1} \mathrm{H}(400 \mathrm{MHz})$ and ${ }^{13} \mathrm{C}$ NMR data $(100 \mathrm{MHz})$ for compound in $\mathrm{CDCl}_{3}(\mathbf{5})$

\begin{tabular}{cccccc}
\hline Position & $\delta_{\mathrm{C}}$ & DEPT-135 & $\delta_{\mathrm{H}}(J, \mathrm{~Hz})$ & $\mathrm{HMBC}$ & $\mathrm{COSY}$ \\
\hline \hline 2 & 76.1 & $(\mathrm{CH})$ & $4.73(\mathrm{tq}, 6.4,1 \mathrm{H})$ & & $\mathrm{CH}_{3}-2, \mathrm{H}-3$ \\
3 & 34.8 & $\left(\mathrm{CH}_{2}\right)$ & $2.93(\mathrm{~d}, 7.3,2 \mathrm{H})$ & $\mathrm{CH}_{3}-2, \mathrm{C}-2, \mathrm{C}-3 \mathrm{a}$, & $\mathrm{H}-2, \mathrm{H}-7$ \\
& & & & $\mathrm{C}-4, \mathrm{C}-7$ & \\
$3 \mathrm{a}$ & 108.5 & $(\mathrm{C})$ & & & \\
4 & 139.5 & $(\mathrm{C})$ & & & $\mathrm{H}-3, \mathrm{H}-6$ \\
5 & 116.4 & $(\mathrm{CH})$ & $6.90(\mathrm{~b} \mathrm{~d}, 8.4,1 \mathrm{H})$ & $\mathrm{C}-3 \mathrm{a}, \mathrm{C}-7$ & $\mathrm{H}-5, \mathrm{H}-7$ \\
6 & 136.3 & $(\mathrm{CH})$ & $\begin{array}{c}7.41(\mathrm{dd}, 8.4,7.4, \\
\text { C-4, C-7a }\end{array}$ & $\mathrm{H}-3, \mathrm{H}-6$ \\
7 & 118.0 & $(\mathrm{CH})$ & $6.69(\mathrm{dd}, 7.4,0.7$, & $\mathrm{C}-3 \mathrm{a}, \mathrm{C}-5$ & \\
$7 \mathrm{a}$ & 162.4 & $(\mathrm{C})$ & $1 \mathrm{H})$ & & $\mathrm{H}-2$ \\
$\mathrm{CH}-2$ & 20.9 & $(\mathrm{CH})$ & $1.54(\mathrm{~d}, 6.3,3 \mathrm{H})$ & $\mathrm{C}-2, \mathrm{C}-3$ & \\
$\overline{\mathrm{COOH}-4}$ & 170.1 & $(\mathrm{C})$ & & &
\end{tabular}


Compound 5 was isolated as a pale yellow amorphous solid (3.2 mg). A molecular formula of $\mathrm{C}_{10} \mathrm{H}_{10} \mathrm{O}_{3}$ was determined based on the $[\mathrm{M}+\mathrm{H}]^{+}$peak at $\mathrm{m} / \mathrm{z} 179.0715$ (calculated $[\mathrm{M}+\mathrm{H}]^{+}$for $\mathrm{C}_{10} \mathrm{H}_{10} \mathrm{O}_{3}$ 179.0708). The UV spectrum displayed an absorption maximum at $217 \mathrm{~nm}$. The IR spectrum displayed a broad absorption peak at $3400 \mathrm{~cm}^{-1}$, and a peak at $1723 \mathrm{~cm}^{-1}$, consistent with the O-H and a carbonyl stretch of a carboxylic acid, respectively. The IR spectrum also displayed $\mathrm{sp}^{3} \mathrm{C}-\mathrm{H}$ stretches at $2926 \mathrm{~cm}^{-1}$ and $2855 \mathrm{~cm}^{-1}$.

The ${ }^{13} \mathrm{C}$ NMR spectrum displayed ten peaks; four quaternary $(\delta 170.1,162.4,139.5$, and 108.5), four methine $(\delta 136.3,118.0,116.4$, and 76.1), one methyl ( $\delta 20.9)$ and one methylene carbon ( $\delta$ 34.8) (determined using the ${ }^{1} \mathrm{H}$ NMR spectrum, HSQC and a DEPT-135 experiment). The ${ }^{1} \mathrm{H}$ NMR spectrum displayed seven signals (integrating for ten protons); one free hydroxyl proton at $\delta 11.03(s)$, three aromatic methine protons at $\delta 7.41(d d, J=8.4,7.4$ $\mathrm{Hz}), 6.90(b d, J=8.4 \mathrm{~Hz})$, and $6.69(d d, J=7.4,0.7 \mathrm{~Hz})$, an oxymethine at $\delta 4.73(t q, J=6.4$ $\mathrm{Hz})$, and two methylene protons at $\delta 2.93(d, J=7.3 \mathrm{~Hz})$. Both the ${ }^{1} \mathrm{H}$ and ${ }^{13} \mathrm{C}$ NMR spectra support the presence of an aromatic ring. The magnitude of the coupling constants between the proton H-5 and H-6, and between $\mathrm{H}-6$ and $\mathrm{H}-7$ are characteristic of ${ }^{3} \mathrm{~J}$, or an ortho relationship on an aromatic ring. COSY correlations between the proton H-6 to each of the protons $\mathrm{H}-5$ and $\mathrm{H}-7$ also supports this determination. Therefore, the substitution on the aromatic ring must be of a 1,2,3-trisubstitution. The chemical shift for the methine proton $\mathrm{H}-2$ 
is consistent with an ether, and the splitting pattern (a triplet of quartets) indicates coupling with five adjacent protons. This is consistent with the oxymethine being next to both a methyl group $\left(\mathrm{CH}_{3}-2\right)$ and a methylene group (H-3). The proton signals for both $\mathrm{CH}_{3}-2$ and H-3 appear as doublets, suggesting coupling to the methine H-2. COSY correlations between these protons are consistent with this determination.

Six aromatic carbon signals were observed in the aromatic region of the ${ }^{13} \mathrm{C}$ spectrum $(\delta$ $162.4,139.5,136.3,118.0,116.4$, and 108.5); three methine and three quaternary, supporting the conclusion of a trisubstituted aromatic ring. The highly deshielded quaternary carbon C-7a is consistent with an aromatic carbon with an ipso ether, while the quaternary carbon C-4 is consistent with an aromatic carbon with an ipso carboxylic acid group (using common shift parameters of substituted benzenes; Balci 2005). The quaternary carbonyl carbon at $\delta 170.3$ is consistent with a carboxylic acid. Therefore the remaining quaternary carbon at $\delta 108.5$ is therefore assigned as $\mathrm{C}-3 \mathrm{a}$, constructing at 2,3-dihydrobenzofuran framework. Based on the HMBC correlation data between H-6 and C-7a, and H-6 and C-4 as well as the chemical shift of C-4 it is determined that the compound is 2-methyl-2,3-dihydrobenzofuran-4-carboxylic acid and not 2-methyl-2,3-dihydrobenzofuran-7-carboxylic acid. If compound 5 was the 7carboxylic acid form, the chemical shift of the carboxylic acid substituted aromatic carbon (C4) would be expected to be much lower due to the ipso carboxylic acid group and the ortho 
ether group (using common shift parameters of substituted benzenes; Balci 2005). The stereochemistry of the methyl group at C-2 was assigned as $R$ after comparison of the optical rotation $\left([\alpha]^{25}=54.1\left[\mathrm{c} 1.1, \mathrm{CH}_{2} \mathrm{Cl}_{2}\right]\right)$ with the closely related compound $(R)$-2-methyl-2,3dihydrobenzofuran $\left([\alpha]^{20}{ }_{D}=20.3\left[\mathrm{c} 1, \mathrm{CH}_{2} \mathrm{Cl}_{2}\right]\right.$; see Figure 26) (Manga-Sanchez et al. 2010). Compound $\mathbf{5}$ is therefore assigned as $(R)$-2-methyl-2,3-dihydrobenzofuran-4-carboxylic acid.

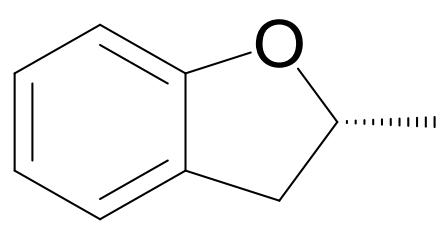

Figure 26: Chemical structure of $(R)$-2-methyl-2,3-dihydro-1-benzofuran. 
OR: $[\alpha]^{25}-4.1\left(\mathrm{c} 1.5, \mathrm{CH}_{3} \mathrm{OH}\right)$

UV-VIS (MeOH): $\lambda_{\max }(\log \varepsilon) 269 \mathrm{~nm}(2.20), 230 \mathrm{~nm}(2.17)$

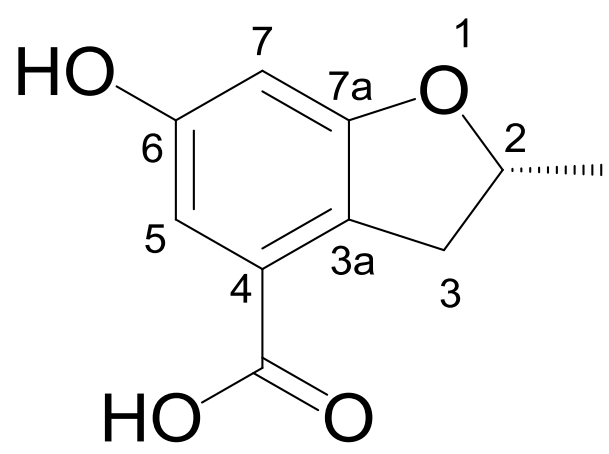

Figure 27: Structure of (R)-6-hydroxy-2-methyl-2,3-dihydrobenzofuran-4-carboxylic acid (6).

Table 6: ${ }^{1} \mathrm{H}(400 \mathrm{MHz})$ and ${ }^{13} \mathrm{C}$ NMR data (100 MHz) for compound (6) in $\mathrm{CD}_{3} \mathrm{OD}$

\begin{tabular}{cccccc}
\hline \hline Position & $\delta_{\mathrm{C}}$ & $\begin{array}{c}\text { DEPT- } \\
135\end{array}$ & $\delta_{\mathrm{H}}(\mathrm{J}, \mathrm{Hz})$ & $\mathrm{HMBC}$ & $\mathrm{COSY}$ \\
\hline \hline 2 & 77.2 & $(\mathrm{CH})$ & $\begin{array}{c}4.69(\mathrm{~m}, 1 \mathrm{H}) \\
2.92(\mathrm{dd}, 16.4,3.6,\end{array}$ & $\mathrm{CH}_{3}-2, \mathrm{H}-3$ \\
3 & 35.5 & & $1 \mathrm{H})$ & $\mathrm{CH}_{3}-2, \mathrm{C}-2, \mathrm{C}-3 \mathrm{a}, \mathrm{C}-4$, & \\
& & $\left(\mathrm{CH}_{2}\right)$ & $2.84(\mathrm{dd}, 16.4,10.9$, & $\mathrm{C}-5$ & $\mathrm{H}-2, \mathrm{H}-3$, \\
& & & $1 \mathrm{H})$ & $\mathrm{H}-5$ \\
$3 \mathrm{a}$ & 101.5 & $(\mathrm{C})$ & & & \\
4 & 143.5 & $(\mathrm{C})$ & & $\mathrm{C}-3, \mathrm{C}-3 \mathrm{a}$ & \\
5 & 107.8 & $(\mathrm{CH})$ & $6.21(\mathrm{~d}, 2.3,1 \mathrm{H})$ & $\mathrm{H}-2$ \\
6 & 165.6 & $(\mathrm{C})$ & & $\mathrm{C}-3 \mathrm{a}, \mathrm{C}-5, \mathrm{C}-6$ & \\
7 & 102.2 & $(\mathrm{CH})$ & $6.20(\mathrm{~d}, 2.3,1 \mathrm{H})$ & $\mathrm{C}-2, \mathrm{C}-3$ & \\
$7 \mathrm{a}$ & 164.1 & $(\mathrm{C})$ & & & \\
$\mathrm{CH}-2$ & 20.9 & $(\mathrm{CH})$ & $1.54(\mathrm{~d}, 6.4,3 \mathrm{H})$ & & \\
$\mathrm{COOH}_{3}-$ & 170.3 & $(\mathrm{C})$ & & &
\end{tabular}


Compound 6 was isolated as a pale yellow amorphous solid (2.2 mg). A molecular formula of $\mathrm{C}_{10} \mathrm{H}_{10} \mathrm{O}_{4}$ was determined based on the $[\mathrm{M}+\mathrm{H}]^{+}$peak at $\mathrm{m} / \mathrm{z} 195.0659$ (calculated $[\mathrm{M}+\mathrm{H}]^{+}$for $\mathrm{C}_{10} \mathrm{H}_{10} \mathrm{O}_{4}$ 195.0657). The UV spectrum displayed absorption maxima at 269 and $230 \mathrm{~nm}$. IR spectrum displayed a broad peak at $3431 \mathrm{~cm}^{-1}$ and intense absorption at $1633 \mathrm{~cm}^{-1}$ consistent with the carbonyl stretch of a conjugated carboxylic acid.

Ten carbon signals were observed on the ${ }^{13} \mathrm{C}$ NMR spectrum; five quaternary $(\delta 170.3,165.6$, $164.1,143.5,101.5)$, three methine $(\delta 107.8,102.2,77.2)$, one methyl carbon $(\delta 20.9)$ and one methylene ( $\delta 35.5$ ) carbon (determined using the ${ }^{1} \mathrm{H}$ NMR spectrum, HSQC and a DEPT-135 experiment). The ${ }^{1} \mathrm{H}$ NMR spectrum displayed six signals, integrating for a total of eight protons; two aromatic methines at $\delta 6.21(d, J=2.3 \mathrm{~Hz})$ and $\delta 6.20(d, J=2.3 \mathrm{~Hz})$, one oxymethine at $\delta 4.69(\mathrm{~m})$, one methylene with the two protons resonating at separate frequencies of $\delta 2.92(d d, J=16.4,3.6 \mathrm{~Hz})$ and $\delta 2.84(d d, J=16.4,10.9 \mathrm{~Hz})$, and a methyl group at $\delta 1.54(d, J=6.4 \mathrm{~Hz})$. Both the ${ }^{1} \mathrm{H}$ and ${ }^{13} \mathrm{C}$ NMR spectra of compound 6 were very similar to compound $\mathbf{5}$ indicating that the two compounds were structurally similar. In contrast to the ${ }^{1} \mathrm{H}$ NMR spectrum of $\mathbf{5}$, only two aromatic proton signals were observed in $\mathbf{6}$, integrating for one each (H-5 and H-7). The magnitude of the coupling constant between these two aromatic protons is consistent with a ${ }^{4} J$ or a meta relationship, indicating a $1,2,3,5-$ tetrasubstituted aromatic ring. Therefore, C-6 must be substituted. An oxygenated methine 
proton peak is observed in the ${ }^{1} \mathrm{H}$ NMR spectrum (C-2) with a similar chemical shift and splitting pattern as was observed in 5. The complicated splitting pattern indicates coupling with five adjacent protons; consistent with being between the methyl group $\mathrm{CH}_{3}-2$ and the methylene group $\mathrm{C}-3$. The methyl proton peak $\left(\mathrm{CH}_{3}-2\right)$ appears as a doublet, which suggests that it is connected to the methine $\mathrm{C}-2$. As in $\mathbf{5}$, the ${ }^{13} \mathrm{C}$ spectrum shows six peaks in the aromatic chemical shift range; two methines and four quaternary. Evidence from both the ${ }^{13} \mathrm{C}$ NMR and ${ }^{1} \mathrm{H}$ NMR spectra are consistent with a tetrasubstituted aromatic ring. A highly deshielded quaternary carbon at $\delta 170.3(\underline{\mathrm{COOH}}-4)$ in the ${ }^{13} \mathrm{C}$ NMR spectrum is consistent with the presence of a carboxylic acid, as in compound $\mathbf{5}$. The chemical shifts of the quaternary carbons C-7a and C-4 are consistent with an aromatic carbon with an ipso ether group, and an aromatic carbon with an ipso carboxylic acid group respectively, as was seen in compound 5. The quaternary carbon at $\delta 165.6$ is therefore assigned as C-6, and the downfield shift indicates direct connection to an oxygen atom, specifically an alcohol group (consistent with the molecular formula). Splitting of the methylene protons at C-3 is therefore likely due to the influence of the para-substitution of the alcohol group to C-6. Based on the HMBC correlation data between H-3 and C-3a, and C-4 it is determined that compound 6 has the same 2,3-dihydrobenzofuran framework as 5. Comparison of the optical rotation of compound $6\left([\alpha]^{25}=-4.1\left[\mathrm{c} 0.1, \mathrm{CH}_{3} \mathrm{OH}\right]\right)$ to compound 5 indicates that it is also $R$. 
Compound $\mathbf{6}$ is assigned as (R)-6-hydroxy-2-methyl-2,3-dihydrobenzofuran-4-carboxylic acid.

3.2.3. (R)-5,7-dichloro-6-hydroxy-2-methyl-2,3-dihydrobenzofuran-4-carboxylic $\underline{\operatorname{acid}(7)}$

OR: $[\alpha]^{25}=-15.6\left(\mathrm{c} 0.4, \mathrm{CH}_{3} \mathrm{OH}\right)$

UV-VIS (MeOH) $\lambda_{\max }(\log \varepsilon): 271 \mathrm{~nm}$ (3.0), $238 \mathrm{~nm}$ (3.0), 316 (2.9)

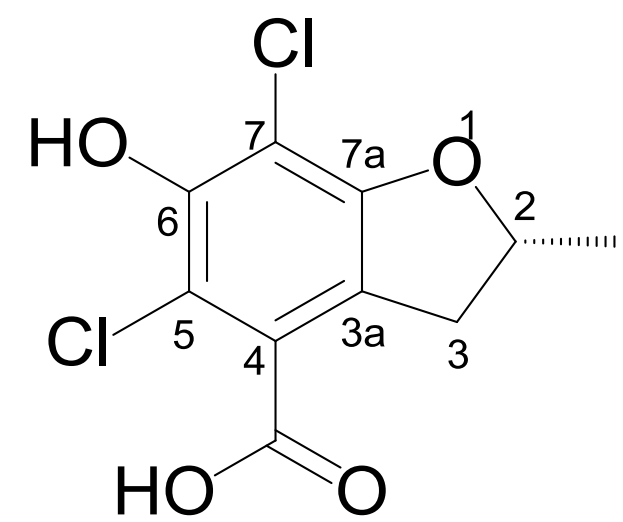

Figure 28: Structure of (R)-5,7-dichloro-6-hydroxy-2-methyl-2,3-dihydrobenzofuran-4carboxylic acid (7).

Table 7: ${ }^{1} \mathrm{H}(400 \mathrm{MHz})$ and ${ }^{13} \mathrm{C}$ NMR data $(100 \mathrm{MHz})$ for compound $(7)$ in $\left(\mathrm{CD}_{3}\right)_{2} \mathrm{CO}$

\begin{tabular}{cccccc}
\hline \hline Position & $\delta_{\mathrm{C}}$ & DEPT-135 & $\delta_{\mathrm{H}}(\mathrm{J}, \mathrm{Hz})$ & $\mathrm{HMBC}$ & $\mathrm{COSY}$ \\
\hline \hline 2 & 76.0 & $(\mathrm{CH})$ & $4.78(\mathrm{~m}, 1 \mathrm{H})$ & & $\mathrm{CH}_{3}-2, \mathrm{H}-3$ \\
3 & 32.7 & & $2.82(\mathrm{dd}, 17.1,11.5,1 \mathrm{H})$ & $\mathrm{CH}_{3}-2, \mathrm{C}-2, \mathrm{C}-3 \mathrm{a}$, & $\mathrm{H}-2, \mathrm{H}-3$ \\
& & $\left(\mathrm{CH}_{2}\right)$ & & $\begin{array}{c}\mathrm{C}-4, \mathrm{C}-7 \\
\mathrm{C}-3 \mathrm{a}, \mathrm{C}-4, \mathrm{C}-7,\end{array}$ & $\mathrm{H}-2, \mathrm{H}-3$ \\
& & & $3.27(\mathrm{dd}, 17.1,3.3,1 \mathrm{H})$ & & \\
$3 \mathrm{a}$ & 101.9 & $(\mathrm{C})$ & & & \\
4 & 137.5 & $(\mathrm{C})$ & & & \\
5 & 108.3 & $(\mathrm{C})$ & & & $\mathrm{H}-2$ \\
6 & 157.8 & $(\mathrm{C})$ & & & \\
7 & 112.1 & $(\mathrm{C})$ & & $\mathrm{C}-2, \mathrm{C}-3$ & \\
$7 \mathrm{a}$ & 159.2 & $(\mathrm{C})$ & & & \\
$\mathrm{CH}_{3}-2$ & 20.8 & $(\mathrm{CH})$ & $1.52(\mathrm{~d}, 6.3,3 \mathrm{H})$ & & \\
$4-\underline{\mathrm{COOH}}$ & 170.3 & $(\mathrm{C})$ & & &
\end{tabular}


Compound 7 was isolated as a pale yellow amorphous solid $(4.0 \mathrm{mg})$. A molecular formula of $\mathrm{C}_{10} \mathrm{H}_{8} \mathrm{O}_{4} \mathrm{Cl}_{2}$ was determined based on the $[\mathrm{M}+\mathrm{H}]^{+}$peak at $\mathrm{m} / \mathrm{z} 262.9893$ (calculated $[\mathrm{M}+\mathrm{H}]^{+}$ for $\mathrm{C}_{10} \mathrm{H}_{8} \mathrm{O}_{4} \mathrm{Cl}_{2}$ 262.9878). The UV spectrum displayed absorption maxima at 271 and 238 $\mathrm{nm}$ suggesting the presence of a carboxylic acid. IR spectrum displayed a broad peak at 3410 $\mathrm{cm}^{-1}$ indicating the presence of an alcohol group and intense absorption at $1642 \mathrm{~cm}^{-1}$ consistent with the carbonyl stretch of a conjugated carboxylic acid.

Ten carbon signals were observed on the ${ }^{13} \mathrm{C}$ NMR spectrum; seven quaternary $(\delta 170.3$, $159.2,157.8,137.5,112.1,108.3$, and 101.9), one methylene $(\delta 32.7)$, one methine $(\delta 76.0)$ and one methyl ( $\delta$ 20.8) (using data from the ${ }^{1} \mathrm{H}$ NMR spectrum, HSQC and a DEPT-135 experiment). Four proton signals were observed on the ${ }^{1} \mathrm{H}$ NMR spectrum - attributed to one methyl group at $\delta 1.52(d, J=6.3 \mathrm{~Hz})$, one methylene group with protons at $\delta 3.27(d d, J=$ $17.1,3.3)$ and $\delta 2.82(d d, J=17.1,11.5)$, and one methine group at $\delta 4.78(d, J=2.3)$. Both the ${ }^{1} \mathrm{H}$ and ${ }^{13} \mathrm{C}$ NMR of compound $\mathbf{7}$ were very similar to compound 5 and $\mathbf{6}$ indicating that all three compounds are structurally similar. In contrast to the ${ }^{1} \mathrm{H}$ NMR spectrum of $\mathbf{5}$ and $\mathbf{6}$, no aromatic proton signals were observed in 7. An oxygenated methine proton peak is observed in the ${ }^{1} \mathrm{H}$ NMR spectrum at $\delta 4.78$, close to that observed in 5 with a similar splitting pattern; indicating coupling with five adjacent protons and consistent with being between a methyl $\left(\mathrm{CH}_{3}-2\right)$ and methylene group (C-3). The protons on the methylene carbon 
at $\delta 32.7$ are split into two separate doublet of doublets $(\delta 3.27, d d, J=17.1,3.3 \mathrm{~Hz}$; and $\delta$ $2.82, d d, J=17.1,11.5 \mathrm{~Hz})$ as was seen in $\mathbf{6}$. The $\mathrm{CH}_{3}$ peak $\delta 1.52(d, J=6.3 \mathrm{~Hz})$ appears as a doublet, which suggests splitting by the methine proton at $\delta 4.78$. As in $\mathbf{5}$, the ${ }^{13} \mathrm{C}$ spectrum shows six peaks in the chemical shift range for an aromatic ring; all six are quaternary. Therefore, based on evidence from the ${ }^{1} \mathrm{H}$ and ${ }^{13} \mathrm{C}$ NMR spectra it is determined that the aromatic ring of compound 7 is fully substituted. A quaternary carbon peak at $\delta 170.3$ in the ${ }^{13} \mathrm{C}$ NMR spectrum indicates the presence of a carboxylic acid, as in compound $\mathbf{5}$. The quaternary carbon at $\delta 159.2$ is consistent with an aromatic carbon with an ipso ether group, and the quaternary carbon at $\delta 137.5$ is consistent with an aromatic carbon with an ipso carboxylic acid group as was seen in compound 5. The quaternary carbon at $\delta 157.8$ is consistent with an oxygenated aromatic carbon and assigned as C-6, while the quaternary carbons at $\delta 108.3$ and $\delta 112.1$ are consistent with halogenated aromatic carbons (as confirmed using common shift parameters of substituted benzenes; Balci, 2005) and therefore assigned as C-5 and C-7. Based on the similarities of the ${ }^{13} \mathrm{C}$ and ${ }^{1} \mathrm{H}$ NMR data to compound $\mathbf{5}$ and $\mathbf{6}$ It is determined that compound $\mathbf{7}$ has the same 2,3-dihydrobenzofuran framework as 5 and 6. Comparison of the optical rotation of compound $7\left([\alpha]^{25}=-15.6\left[\mathrm{c} 0.4, \mathrm{CH}_{3} \mathrm{OH}\right]\right)$ to compound $\mathbf{5}$ indicates that it is also $(R)$. Compound 7 is therefore assigned as $(R)-5,7-$ dichloro-6-hydroxy-2-methyl-2,3-dihydrobenzofuran-4-carboxylic acid. 
3.2.4. (R)-5,7-dichloro-6-methoxy-2-methyl-2,3-dihydrobenzofuran-4-carboxylic $\underline{\operatorname{acid}(8)}$

OR: $[\alpha]^{25}=-110.3\left(\mathrm{c} 1.7, \mathrm{CH}_{3} \mathrm{OH}\right)$

UV-VIS (MeOH) $\lambda_{\max }(\log \varepsilon): 268 \mathrm{~nm}(1.8)$

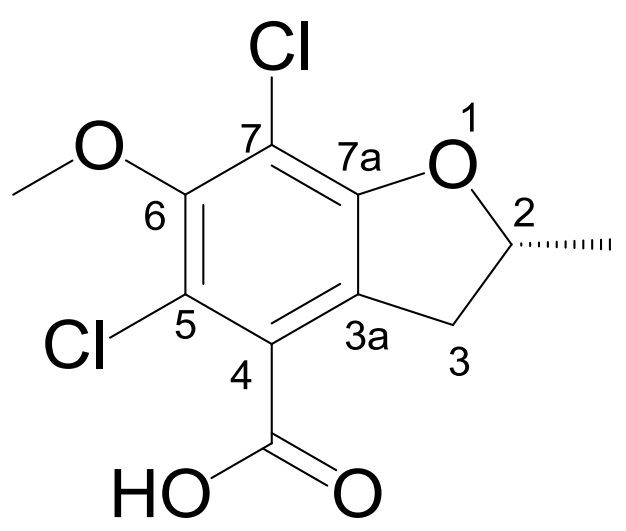

Figure 29: Structure of $(R)$-5,7-dichloro-6-methoxy-2-methyl-2,3-dihydrobenzofuran-4carboxylic acid $(\mathbf{8})$. 
Table 8: ${ }^{1} \mathrm{H}(400 \mathrm{MHz})$ and ${ }^{13} \mathrm{C}$ NMR data $(100 \mathrm{MHz})$ for compound $(8)$ in $\mathrm{CD}_{3} \mathrm{CN}$

\begin{tabular}{|c|c|c|c|c|c|}
\hline Position & $\overline{\delta_{\mathrm{C}}}$ & $\begin{array}{c}\text { DEPT- } \\
135\end{array}$ & $\overline{\delta_{\mathrm{H}}(\mathrm{J}, \mathrm{Hz})}$ & HMBC & COSY \\
\hline 2 & 74.3 & $\begin{array}{l}\mathrm{CH}) \\
\end{array}$ & $4.53(\mathrm{~m}, 1 \mathrm{H})$ & & $\begin{array}{c}\mathrm{CH}_{3}-2, \mathrm{H}- \\
3\end{array}$ \\
\hline \multirow[t]{2}{*}{3} & 33.9 & $\left(\mathrm{CH}_{2}\right)$ & $2.72(\mathrm{dd}, 17.0,11.6,1 \mathrm{H})$ & $\begin{array}{c}\mathrm{CH}_{3}-2, \mathrm{C}-2, \mathrm{C}-5, \mathrm{C}- \\
7\end{array}$ & H-2, H-3 \\
\hline & & & $3.19(\mathrm{dd}, 17.0,2.8,1 \mathrm{H})$ & C-5, C-7 & $\mathrm{H}-3$ \\
\hline $3 a$ & 116.8 & (C) & & & \\
\hline 4 & 139.9 & (C) & & & \\
\hline 5 & 113.2 & (C) & & & \\
\hline 6 & 158.9 & (C) & & & \\
\hline 7 & 115.8 & (C) & & & \\
\hline $7 \mathrm{a}$ & 154.9 & (C) & & & \\
\hline $\mathrm{CH}_{3}-2$ & 20.6 & $\left(\mathrm{CH}_{3}\right)$ & $1.43(\mathrm{~d}, 6.3,3 \mathrm{H})$ & $\mathrm{C}-2, \mathrm{C}-3$ & $\mathrm{H}-2$ \\
\hline$\frac{\mathrm{COOH}-}{4}$ & 161.9 & (C) & & & \\
\hline$\underline{\mathrm{CH}}_{3} \mathrm{O}-6$ & 62.4 & $\left(\mathrm{CH}_{3}\right)$ & $3.88(\mathrm{~s}, 3 \mathrm{H})$ & C-6 & \\
\hline
\end{tabular}

Compound $\mathbf{8}$ was isolated as a pale yellow amorphous solid $(33.7 \mathrm{mg})$. It was assigned the molecular formula $\mathrm{C}_{11} \mathrm{H}_{10} \mathrm{O}_{4} \mathrm{Cl}_{2}$ based on the $[\mathrm{M}+\mathrm{H}]^{+}$peak at $\mathrm{m} / z 277.0044$ (calculated $[\mathrm{M}+\mathrm{H}]^{+}$for $\mathrm{C}_{11} \mathrm{H}_{10} \mathrm{O}_{4} \mathrm{Cl}_{2}$ 277.0034). The UV spectrum displayed an absorption maximum at $268 \mathrm{~nm}$ suggesting. The IR spectrum displayed a broad peak at $3401 \mathrm{~cm}^{-1}$ indicating the presence of an alcohol group and intense absorption at $1698 \mathrm{~cm}^{-1}$ consistent with the carbonyl stretch of a conjugated carboxylic acid. Comparison of the ${ }^{1} \mathrm{H}$ NMR and ${ }^{13} \mathrm{C}$ NMR spectra of compound 8 to the spectra of compounds 5-7 indicates structural similarities between the compounds. The ${ }^{13} \mathrm{C}$ NMR spectrum displayed eleven peaks; seven quaternary $(\delta 161.3$, $158.9,154.9,139.9,116.8,115.8$, and 113.2), one methine $(\delta 74.3)$, one methylene $(\delta 33.9)$, and two methyl $(\delta 62.4,20.6)$ (using data from the ${ }^{1} \mathrm{H}$ NMR spectrum, HSQC and a DEPT135 experiment). As in compound 7, no aromatic proton signals were observed in the ${ }^{1} \mathrm{H}$ 
NMR spectrum, however six carbons in the aromatic range were observed in the ${ }^{13} \mathrm{C} N M R$ spectrum; indicating a fully substituted aromatic ring. Based on the similar carbon and proton shifts observed in the ${ }^{1} \mathrm{H}$ and ${ }^{13} \mathrm{C}$ NMR spectra of $\mathbf{8}$ as compared to compounds $\mathbf{5 - 7}$, as well as the similar HMBC and COSY correlations observed it was determined that compound $\mathbf{8}$ also has a 2,3-dihydrobenzofuran framework. However, an additional oxygenated methyl carbon peak was observed at $\delta 62.4$ (methyl protons at $\delta 3.88[s]$ ). An HMBC correlation to C-6 indicated that the $\mathrm{OH}$ group at $\mathrm{C}-6$ had been replaced by a methoxy group. Again, comparing the optical rotation of $\mathbf{8}$ to the other three compounds, compound $\mathbf{8}$ is assigned as $(R)-5,7-$ dichloro-6-methoxy-2-methyl-2,3-dihydrobenzofuran-4-carboxylic acid.

\subsubsection{4-(methoxymethyl)-2-7-dimethyl-9H-xanthene (9)}

UV-VIS (MeOH): $\lambda_{\max }(\log \varepsilon) 285 \mathrm{~nm}(3.03), 229 \mathrm{~nm}(3.19)$

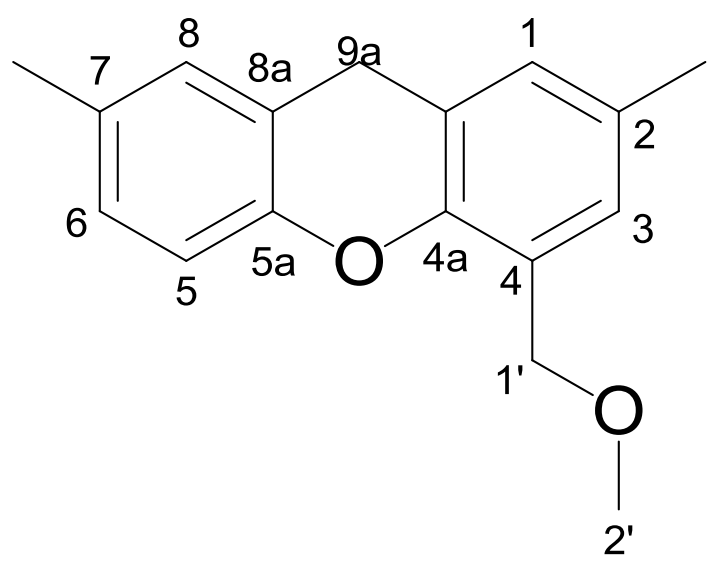

Figure 30: Structure of 4-(methoxymethyl)-2-7-dimethyl-9H-xanthene (9). 
Table 9: ${ }^{1} \mathrm{H}$ and $\left(\mathrm{CD}_{3} \mathrm{OD}, 400 \mathrm{MHz}\right)$ and ${ }^{13} \mathrm{C}$ NMR $\left(\mathrm{CD}_{3} \mathrm{OD}, 100 \mathrm{MHz}\right)$ for 9

\begin{tabular}{cccccc}
\hline \hline Position & $\delta_{\mathrm{C}}$ & DEPT-135 & $\delta_{\mathrm{H}}(\mathrm{J}, \mathrm{Hz})$ & $\mathrm{HMBC}$ & $\mathrm{COSY}$ \\
\hline \hline 1 & 129.0 & $(\mathrm{CH})$ & $6.86(\mathrm{~d}, 1.8,1 \mathrm{H})$ & $\mathrm{CH}_{3}-2$ & $\mathrm{H}-9$ \\
2 & 129.2 & $(\mathrm{C})$ & & & \\
3 & 132.0 & $(\mathrm{CH})$ & $6.91(\mathrm{bs}, 2 \mathrm{H})$ & $\mathrm{CH}_{3}-2, \mathrm{C}-9$ & \\
& & & coincident with $\mathrm{H}-8$ & & \\
4 & 128.3 & $(\mathrm{C})$ & & & $\mathrm{H}-6$ \\
$4 \mathrm{a}$ & 151.8 & $(\mathrm{C})$ & & $\mathrm{C}-6, \mathrm{C}-7$ & \\
5 & 115.8 & $(\mathrm{CH})$ & $6.66(\mathrm{~d}, 8.1,1 \mathrm{H})$ & & $\mathrm{H}-5, \mathrm{CH}_{3}-7$ \\
$5 \mathrm{a}$ & 152.7 & $(\mathrm{C})$ & & & \\
6 & 128.7 & $(\mathrm{CH})$ & $6.81(\mathrm{dd}, 8.1,1.8,1 \mathrm{H})$ & & \\
7 & 130.3 & $(\mathrm{C})$ & & $\mathrm{CH}-7, \mathrm{C}-9$ & $\mathrm{H}-8$ \\
8 & 131.8 & $(\mathrm{CH})$ & $6.91(\mathrm{bs}, 2 \mathrm{H})$ & & \\
& & & coincident with H-3 & & \\
$8 \mathrm{a}$ & 130.0 & $(\mathrm{C})$ & & & \\
9 & 31.1 & $\left(\mathrm{CH}_{2}\right)$ & $3.81(\mathrm{~s}, 2 \mathrm{H})$ & $\mathrm{C}-1, \mathrm{C}-4 \mathrm{a}, \mathrm{C}-8$ & \\
$9 \mathrm{a}$ & 125.3 & $(\mathrm{C})$ & & & \\
1 & 72.1 & $\left(\mathrm{CH}_{2}\right)$ & $4.48(\mathrm{~s}, 2 \mathrm{H})$ & $\mathrm{C}-1, \mathrm{C}-2$ ', C-4a, C-9a, & \\
2 & 58.2 & $\left(\mathrm{CH}_{3}\right)$ & $3.36(\mathrm{~s}, 3 \mathrm{H})$ & $\mathrm{C}-1, \mathrm{C}-3$ & $\mathrm{H}-8$ \\
$\mathrm{CH}_{3}-2$ & 20.6 & $\left(\mathrm{CH}_{3}\right)$ & $2.17(\mathrm{~s}, 3 \mathrm{H})$ & $\mathrm{C}-7, \mathrm{C}-8$ & \\
$\mathrm{CH}_{3}-7$ & 20.6 & $\left(\mathrm{CH}_{3}\right)$ & $2.19(\mathrm{~s}, 3 \mathrm{H})$ & &
\end{tabular}

Compound 9 was isolated as a pale yellow oil $(4.1 \mathrm{mg})$ and assigned the molecular formula $\mathrm{C}_{17} \mathrm{H}_{18} \mathrm{O}_{2}$ based on the $[\mathrm{M}+\mathrm{H}]^{+}$peak at $\mathrm{m} / z 255.1346$ (calculated $[\mathrm{M}+\mathrm{H}]^{+}$for $\mathrm{C}_{17} \mathrm{H}_{18} \mathrm{O}_{2}$ 255.1385). The UV spectrum displayed an absorption maximum at $268 \mathrm{~nm}$. The IR spectrum displayed $\mathrm{sp}^{3} \mathrm{C}-\mathrm{H}$ stretches at 2963 and $2928 \mathrm{~cm}^{-1}$.

The ${ }^{13} \mathrm{C}$ NMR spectrum displayed sixteen peaks; seven quaternary $(\delta 152.7,151.8,130.3$, $130.0,129.2,128.3$, and 125.3), five methine ( $\delta 132.0,131.8,129.0,128.7$, and 115.8), two methyl ( $\delta$ 52.8, and 20.6) and two methylene carbons ( $\delta$ 72.1, and 31.1) (as determined by 
HSQC and a DEPT-135 experiment). HSQC correlations between the methyl carbon at $\delta$ 20.6 to two sets of methyl protons at $\delta 2.19$, and 2.17 , indicated that it is representative of two methyl carbons. The ${ }^{1} \mathrm{H}$ NMR spectrum displayed nine signals integrating for eighteen protons; three methyl groups at $\delta 3.36(s), 2.19(s)$, and $2.17(s)$, two methylene groups at $\delta$ $72.1(s)$ and $31.1(s)$, and four aromatic protons at $\delta 6.91(\mathrm{bs}$; two coincident signals), $6.86(d$, $J=1.8 \mathrm{~Hz}), 6.81(d d, J=8.1,1.8 \mathrm{~Hz})$ and $6.66(d, J=8.1)$. Both the ${ }^{1} \mathrm{H}$ and ${ }^{13} \mathrm{C}$ NMR spectra suggest the presence of two aromatic rings. The protons H-6 and H-5 are in an ortho position to each other based on the coupling constants observed, while H-6 also shows coupling to a meta proton with a coupling constant of $1.8 \mathrm{~Hz}$. This is consistent with a 1,2,4-trisubstituted aromatic system. Based on the splitting of the aromatic proton $(\mathrm{H}-1)$, it also couples to a meta aromatic proton, suggesting that the second aromatic ring is of a 1,2,3,5-tetrasubstituted nature. Based on the HMBC correlations between the methylene protons at $\mathrm{H}-9$ and the aromatic carbons $\mathrm{C}-8$ and $\mathrm{C}-1$ it is determined that $\mathrm{C}-9$ is in between the two aromatic ring systems (ortho to the methine carbons C-8 and C-1). Also, the HMBC correlation between the methyl group protons $\left(\mathrm{CH}_{3}-2\right.$ and $\left.\mathrm{CH}_{3}-7\right)$ to $\mathrm{C}-1$ and $\mathrm{C}-8$ respectively indicates that they are also ortho to the methine carbons. Two oxygenated aromatic quaternary carbons are observed at $\delta 152.7$ and 151.8 forming a xanthene structure. The chemical shifts of carbons $4 \mathrm{a}$ and $5 \mathrm{a}$ were compared to the chemical shifts of the similar compound $9 \mathrm{H}$-xanthene as reported by Osborne et al. (1995), and Dradi and Gatti (1975), and were found to be consistent. A methyl 
signal at $\delta 72.1$ is consistent with direct attachment with an oxygen atom, and the methyl signal at $\delta 58.2$ is consistent with the chemical shift of a methyl ether. Therefore, based on the HMBC correlation of $\mathrm{H}-1^{\prime}$ to $\mathrm{C}-2$ ', to $\mathrm{C}-4 \mathrm{a}, \mathrm{C}-9 \mathrm{a}$ and $\mathrm{C}-1$ it is determined that $\mathrm{C}-4$ is the location of substitution of the methoxymethyl group, thus leading to the determination that compound 5 is 4-(methoxymethyl)-2-7-dimethyl-9H-xanthene.

\subsubsection{6-ethylidenecyclohex-4-ene-1,2,3-triol (10)}

OR: $[\alpha]^{25}=-14.6\left(\mathrm{c} 0.3, \mathrm{CH}_{3} \mathrm{OH}\right)$

UV-VIS (MeOH): $\lambda_{\max }(\log \varepsilon) 233 \mathrm{~nm}(2.05)$
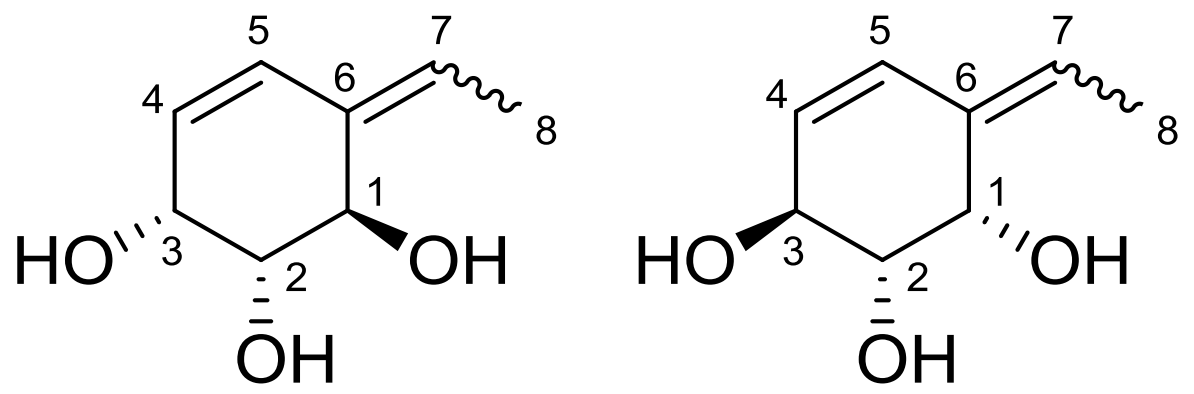

Figure 31: Structure of 6-ethylidenecyclohex-4-ene-1,2,3-triol (10). 
Table 10: ${ }^{1} \mathrm{H}$ and $\left(\mathrm{CDCl}_{3}, 400 \mathrm{MHz}\right)$ and ${ }^{13} \mathrm{C} \mathrm{NMR}\left(\mathrm{CDCl}_{3}, 100 \mathrm{MHz}\right)$ for 6ethylidenecyclohex-4-ene-1,2,3-triol (10)

\begin{tabular}{|c|c|c|c|c|c|}
\hline Position & $\delta_{\mathrm{C}}$ & $\begin{array}{c}\text { DEPT- } \\
135 \\
\end{array}$ & $\overline{\delta_{\mathrm{H}}(\mathrm{J}, \mathrm{Hz})}$ & HMBC & COSY \\
\hline 1 & 81.2 & $\overline{(\mathrm{CH})}$ & $\begin{array}{l}5.01(\mathrm{~m}, 1 \mathrm{H}) \\
\end{array}$ & C-2, C-5, C-6 & OH-1, H-2 \\
\hline 2 & 68.9 & $(\mathrm{CH})$ & $\begin{array}{c}4.30(\mathrm{dd}, 5.1,3.7 \\
1 \mathrm{H})\end{array}$ & C-1, C-5, C-6 & $\mathrm{H}-1, \mathrm{H}-3$ \\
\hline 3 & 73.3 & $(\mathrm{CH})$ & $4.82(\mathrm{~m}, 1 \mathrm{H})$ & & $\begin{array}{c}\mathrm{H}-2, \mathrm{OH}-3, \mathrm{H}- \\
5\end{array}$ \\
\hline 4 & 124.7 & $(\mathrm{CH})$ & $\begin{array}{c}6.12(\mathrm{~m}, 2 \mathrm{H}) \\
\text { coincident with } \mathrm{H}-7\end{array}$ & C-5, C-6 & \\
\hline 5 & 128.5 & $(\mathrm{CH})$ & $5.74(\mathrm{~d}, 2.4,1 \mathrm{H})$ & $\mathrm{C}-1, \mathrm{C}-2, \mathrm{C}-3$ & H-1, H-3, H-8 \\
\hline 6 & 144.9 & (C) & & & \\
\hline 7 & 131.6 & $(\mathrm{CH})$ & $\begin{array}{c}6.12(\mathrm{~m}, 2 \mathrm{H}) \\
\text { coincident with } \mathrm{H}-4\end{array}$ & C-5, C-6, C-8 & H-8 \\
\hline 8 & 18.7 & $\left(\mathrm{CH}_{3}\right)$ & $1.81(\mathrm{~d}, 4.5,3 \mathrm{H})$ & C-6, C-7 & H-7 \\
\hline $\mathrm{OH}-1$ & & & $1.96(\mathrm{~d}, 5.7,1 \mathrm{H})$ & $\begin{array}{c}\mathrm{C}-1, \mathrm{C}-2, \mathrm{C}-6, \mathrm{C}- \\
8\end{array}$ & $\mathrm{H}-1$ \\
\hline $\mathrm{OH}-3$ & & & $2.20(\mathrm{~d}, 7.3,1 \mathrm{H})$ & C-2, C-3, C-5 & H-3 \\
\hline
\end{tabular}

Compound 10 was isolated as a white amorphous solid $(4.3 \mathrm{mg})$ and given the molecular formula $\mathrm{C}_{8} \mathrm{H}_{12} \mathrm{O}_{3}$ based on the $[\mathrm{M}+\mathrm{H}]^{+}$peak at $\mathrm{m} / z 157.0856$ (calculated $[\mathrm{M}+\mathrm{H}]^{+}$for $\mathrm{C}_{8} \mathrm{H}_{12} \mathrm{O}_{3}$ 157.0865). Based on the molecular formula, a degree of unsaturation of three was calculated for compound $\mathbf{1 0 .}$

The ${ }^{13} \mathrm{C}$ NMR displayed eight signals; one quaternary $(\delta$ 144.9), six methine $(\delta 131.6,128.5$, 124.7, 81.2, 73.3, and 68.9), and one methyl ( $\delta$ 18.7) (as determined by HSQC and DEPT135). The ${ }^{1} \mathrm{H}$ NMR spectrum displayed eight signals, integrating for a total of eleven protons. Based on the HSQC and DEPT-135 experiment it was possible to determine that the proton 
signal at $\delta 6.12(\mathrm{~m})$, integrating for two protons, belonged to two separate methines. Based on integration of the ${ }^{1} \mathrm{H}$ spectrum, HSQC and a DEPT-135 experiment, the remaining seven proton signals were determined to be as follows: four methine protons at $\delta 5.74(d, J=2.4$ $\mathrm{Hz}), \delta 5.01(t, J=4.5 \mathrm{~Hz}), \delta 4.82(t, J=6.4 \mathrm{~Hz})$, and $\delta 4.30(d d, J=5.1,3.7 \mathrm{~Hz})$, one methyl group at $\delta 1.81(d, J=4.5 \mathrm{~Hz})$, and two free hydroxyl groups $\delta 2.20(d, J=7.3 \mathrm{~Hz})$ and $\delta 1.96$ $(d, J=5.7 \mathrm{~Hz})$. No aromatic protons were observed on the ${ }^{1} \mathrm{H}$ NMR spectrum. The protons $\mathrm{H}-$ 7, $\mathrm{H}-5$ and $\mathrm{H}-4$ are consistent with olefinic protons, indicating the presence of two double bonds. Based on the unsaturation degree of three, it is therefore determined that the compound must have a ring structure. HMBC correlations between $\mathrm{H}-8$ to $\mathrm{C}-7$ and $\mathrm{C}-6$ as well as the HMBC correlations of $\mathrm{H}-7$ to $\mathrm{C}-8, \mathrm{C}-6$, and $\mathrm{C}-1$ indicate the presence of an ethylidene moiety, substituted at the quaternary carbon C-6. The downfield shift of C-6 indicates that it is part of a ring structure; forming a substituted cyclohexane. The methine protons $\mathrm{H}-3, \mathrm{H}-2$ and $\mathrm{H}-1$ are shifted downfield from expected, consistent with being attached to an alcohol-bearing carbon atom. COSY correlations from $\mathrm{H}-1$ to $\mathrm{H}-2$, from $\mathrm{H}-2$ to $\mathrm{H}-1$ and H-3 indicate that the alcohol groups are adjacent to each other, with $\mathrm{C}-2$ being between $\mathrm{C}-1$ and C-3. The relative stereochemistry of compound 7 was established by consideration of coupling constants of protons. Based on the coupling constants of $\mathrm{H}-2(J=5.1,3.7 \mathrm{~Hz})$ it can be said that it has an axial-equatorial relationship with either $\mathrm{H}-1$ or $\mathrm{H}-3$, however due to the unresolved nature of the ${ }^{1} \mathrm{H}$ NMR signals for $\mathrm{H}-1$ and $\mathrm{H}-3$ it was not possible to determine 
which of the two was in the axial position and which was in the equatorial position. Additionally, the difference between the two coupling constants also suggests that one of the protons is in the axial position and the resulting coupling constant of $J=5.1 \mathrm{~Hz}$ is due to flexibility in the ring structure at C-2. This flexibility allows for $\mathrm{H}-2$ to be in either the equatorial or axial position as the ring alternates between a planar and a twist chair conformation. Further NMR data could not be obtained to confirm the geometry of H-1 and H-3 due to degradation of the compound. Compound $\mathbf{1 0}$ has been assigned as 6ethylidenecyclohex-4-ene-1,2,3-triol. 
3.2.6. Comparison of metabolite production between strains DAOM 242779 and DAOM 242780

A comparison of the major metabolites isolated from strains DAOM 242779 and DAOM 242780 was carried out. The results of this comparison can be found in Table 11 below.

Compounds 5-8, and 10 were identified in both strains, whereas the xanthene (9) was only identified from strain DAOM 242779.

Table 11: Metabolite production of strains DAOM 242779 and DAOM 242780

\begin{tabular}{lllllll}
\hline Strains & $\mathbf{5}$ & $\mathbf{6}$ & $\mathbf{7}$ & $\mathbf{8}$ & $\mathbf{9}$ & $\mathbf{1 0}$ \\
\hline DAOM & ++ & ++ & ++ & +++ & ++ & ++ \\
242779 & & & & & & + \\
DAOM & +++ & + & + & ++ & - & + \\
242780 & & & & & & \\
\hline
\end{tabular}

$(+),<0.5 \mathrm{mg} / \mathrm{L} ;(++)>2 \mathrm{mg} / \mathrm{L} ;(+++)>5 \mathrm{mg} / \mathrm{L}$

\subsubsection{ANTIMICROBIAL ASSAYS}

Compounds 5-9 were tested for in vitro antimicrobial activity against $P$. fluorescens (ATCC 12633), B. subtilis (ATCC 23857), and S. cerevisiae using the 96-well microplate technique described by Sumarah et al. (2011). Antimicrobial OD data were analyzed by ANOVA followed by Tukey's test for significant differences (Systat V13) compared to the negative control (DMSO). 


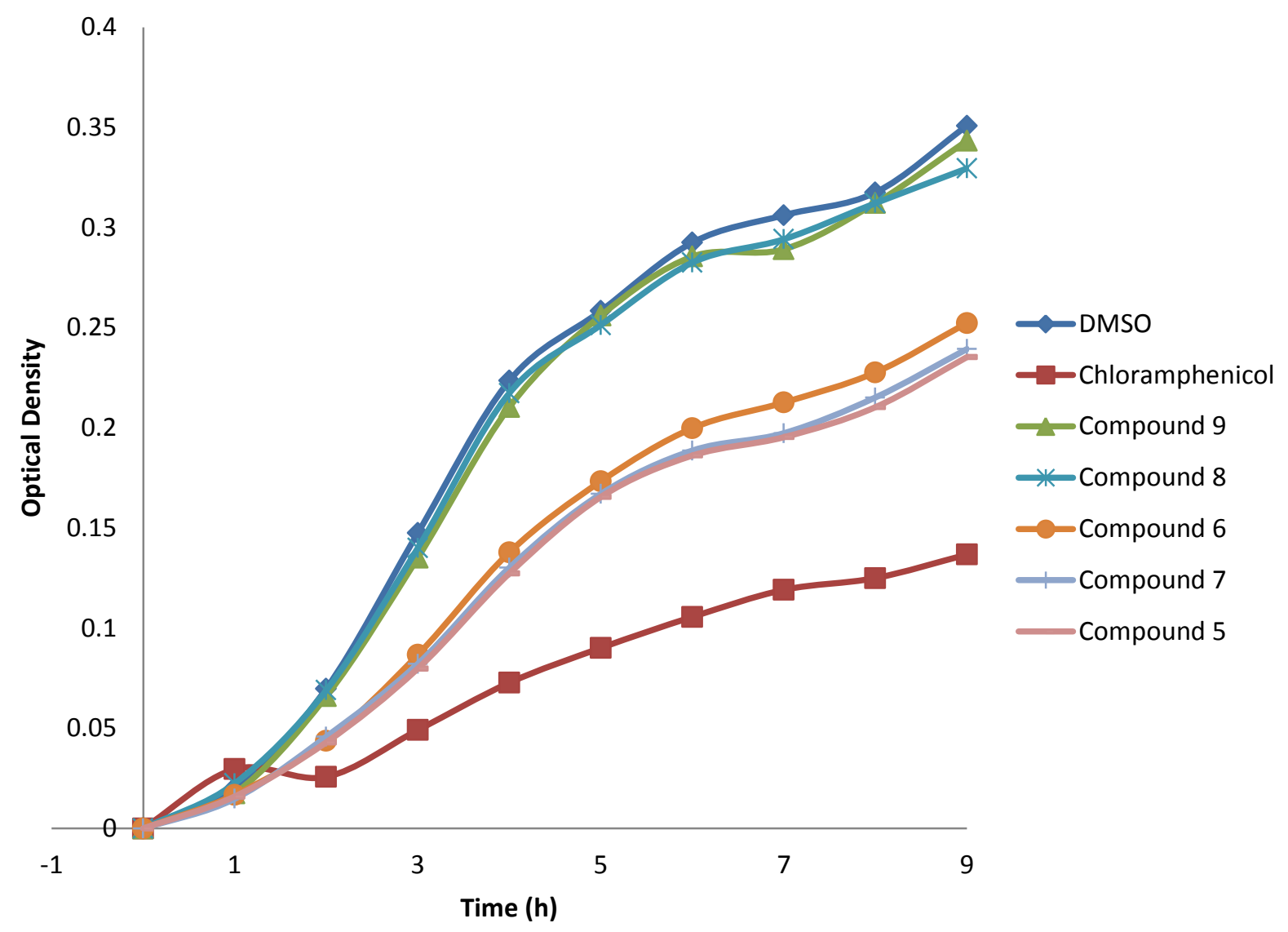

Figure 32: Effect of compounds 5-9 at $50 \mu \mathrm{M}$ on cell growth of B. subtilis. 


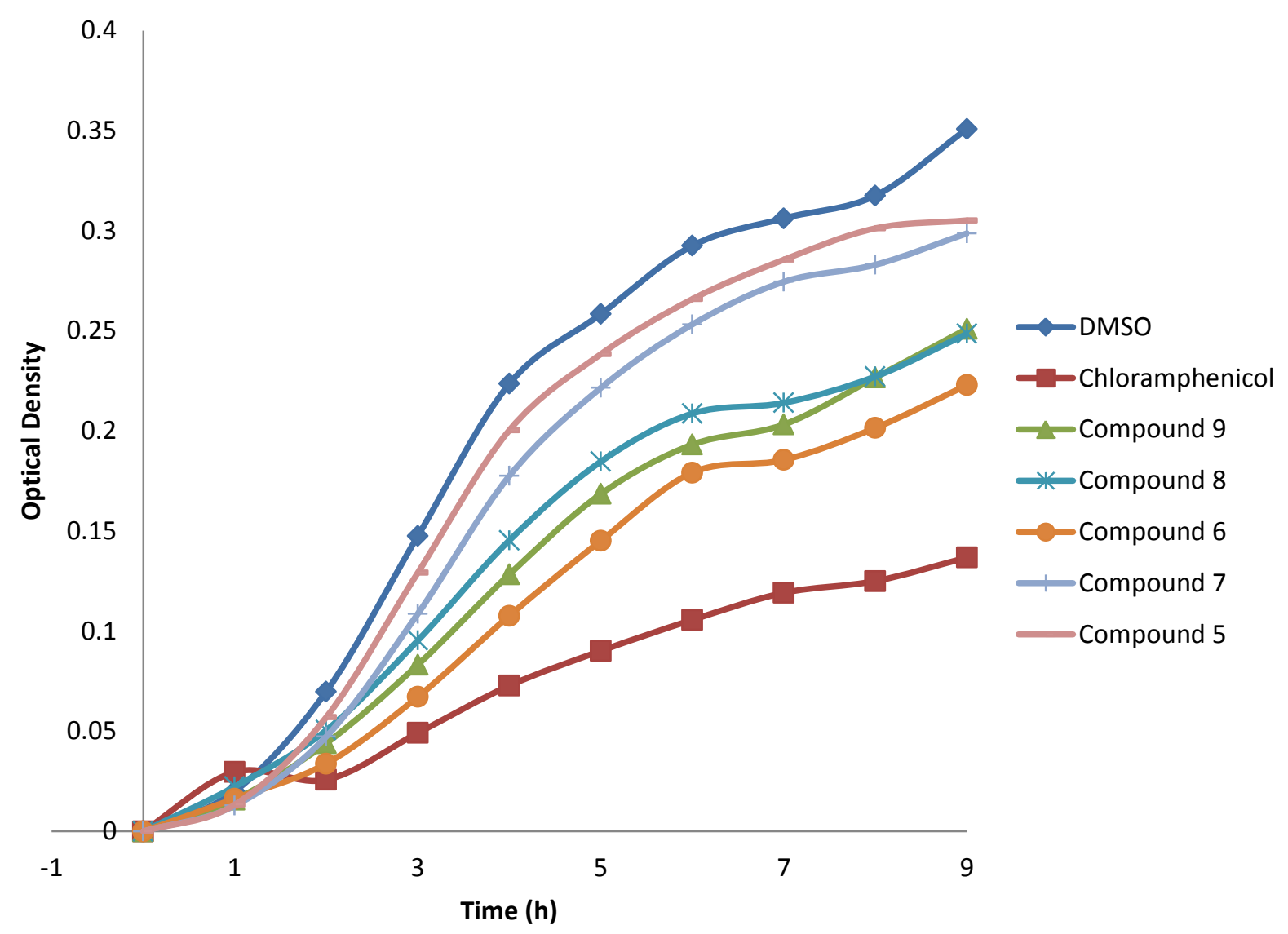

Figure 33: Effect of compounds 5-9 at $100 \mu \mathrm{M}$ on cell growth of B. subtilis.

Compounds $\mathbf{5}, \mathbf{6}$, and 7 displayed significant bioactivity against the gram positive bacteria $B$. subtilis at a concentration of $50 \mu \mathrm{M} ; p=0.000, p=0.005$, and $p=0.001$ respectively. An inhibitory effect was also observed for compounds $\mathbf{8}$, and $\mathbf{9}$ against $B$. subtilis at $100 \mu \mathrm{M} ; p=$ $0.003, p=0.000$, and $p=0.000$ respectively. 


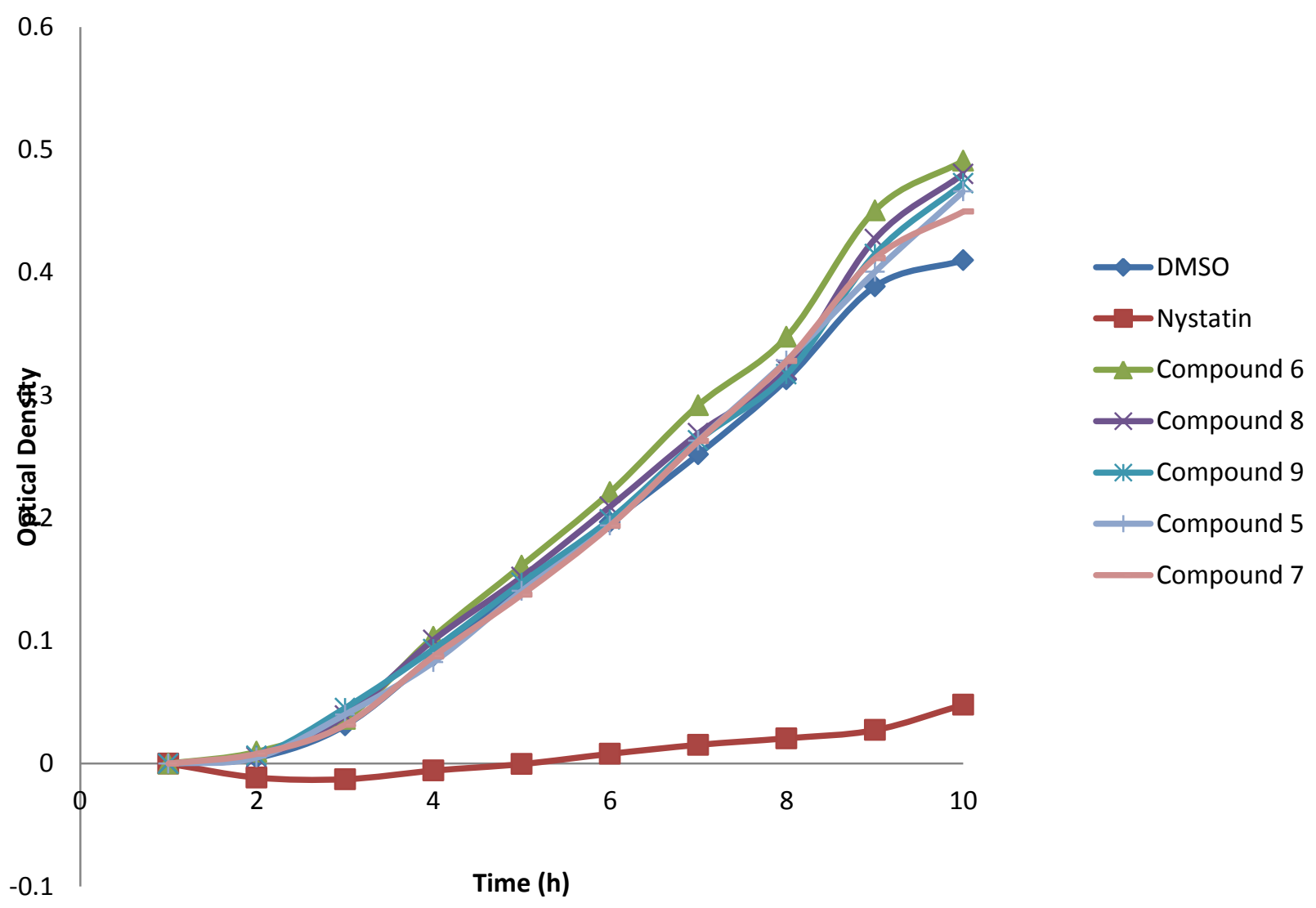

Figure 34: Effect of compounds 5-9 at $100 \mu \mathrm{M}$ on cell growth of P. fluorescens. 


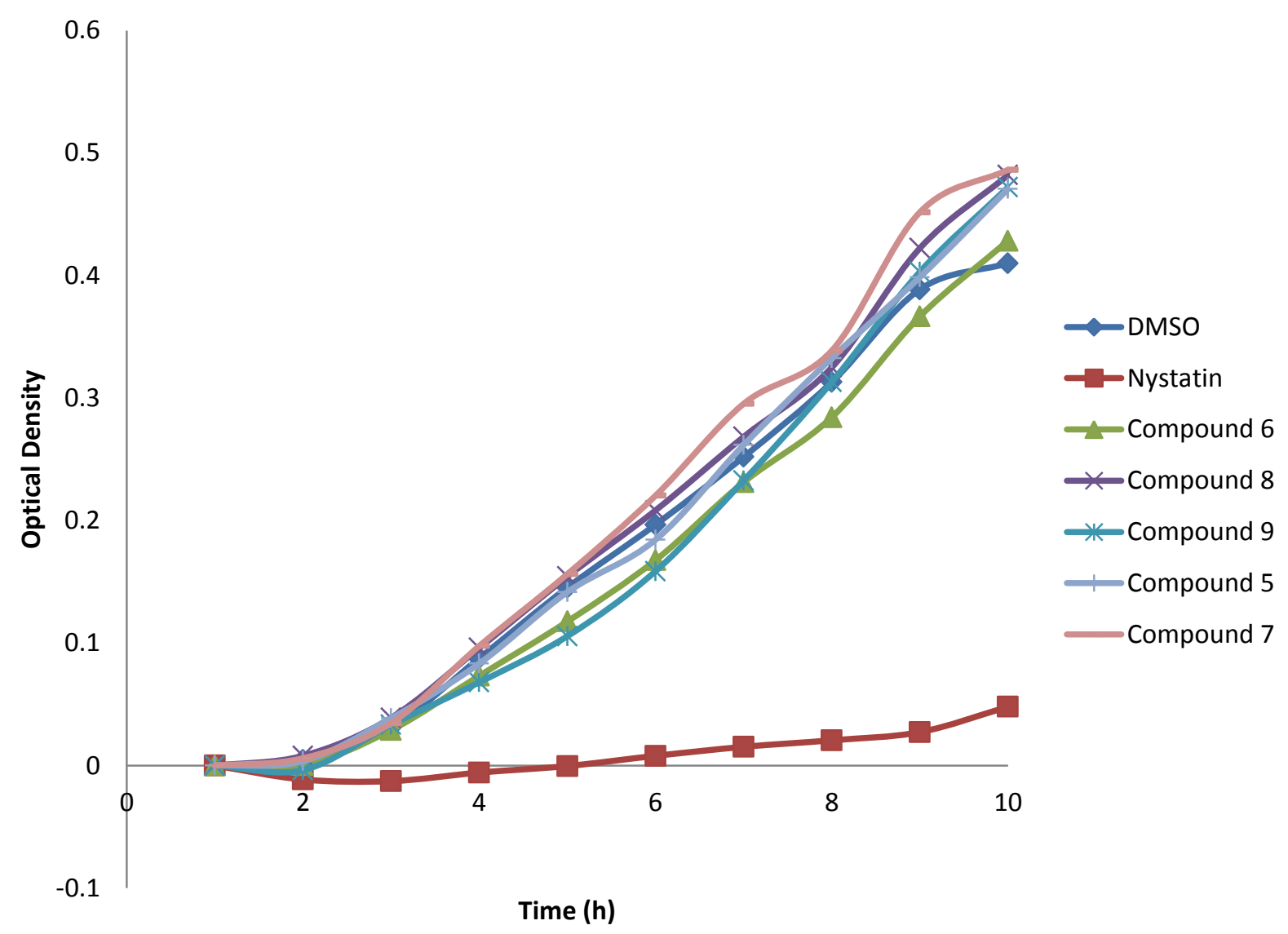

Figure 35: Effect of compounds 5-9 at $500 \mu \mathrm{M}$ on cell growth of $P$. fluorescens.

None of compounds 5-9 were shown to inhibit growth of $P$. fluorescens at concentrations up to $500 \mu \mathrm{M}$. 


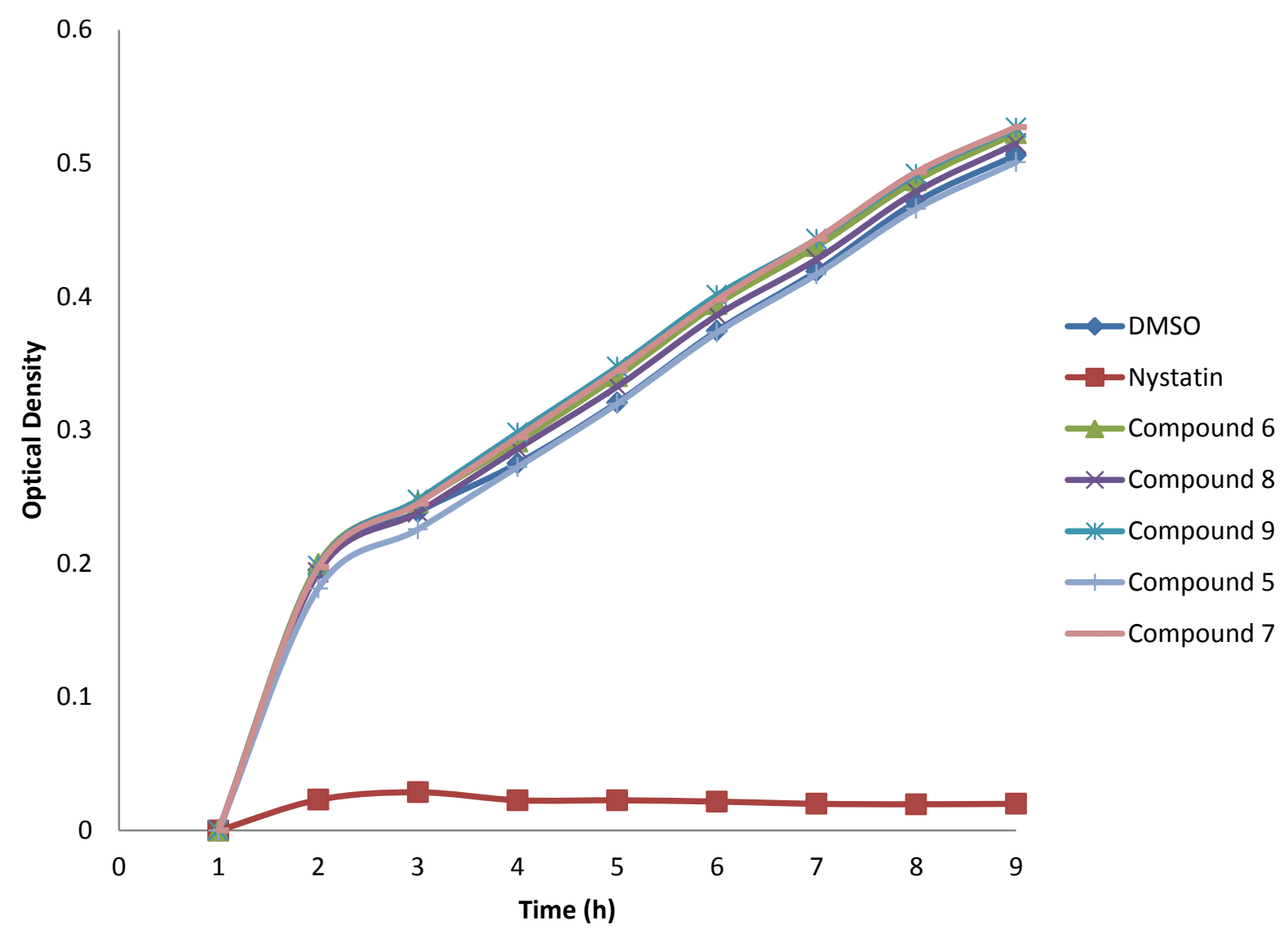

Figure 36: Effect of compounds 5-9 at $100 \mu \mathrm{M}$ on cell growth of S. cerevisiae. 


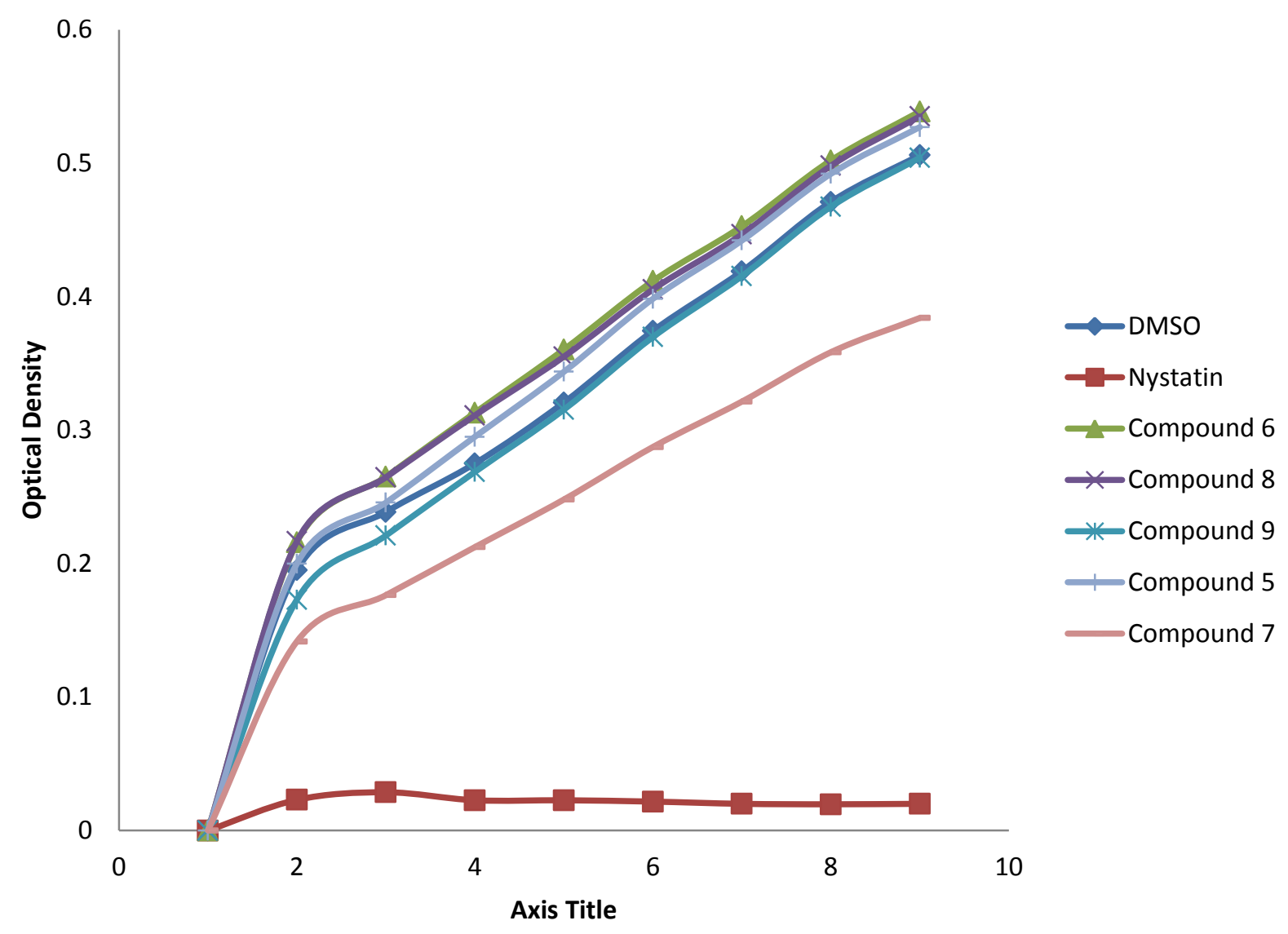

Figure 37: Effect of compounds 5-9 at $500 \mu \mathrm{M}$ on cell growth of $S$. cerevisiae.

None of compounds 5-9 were shown to inhibit growth of S. cerevisiae at concentrations up to $500 \mu \mathrm{M}$. 


\subsection{IDENTIFICATION AND QUANTITATION OF GRISEOFULVIN IN Xylaria SP.}

The known antifungal compound, griseofulvin (Figure 6), was previously isolated in the Miller laboratory from an endophyte of Pinus strobus. Genetic identification of the species using the ITS sequence revealed a number of endophyte strains isolated were of the same species; including strain T5.1B.1. An analysis of the crude extracts of these strains was carried out using LC-MS in Multiple Reaction Monitoring (MRM) mode. Table 12 displays the results of this analysis.

Table 12: Quantitation of griseofulvin producing Xylaria sp.

\begin{tabular}{cccc}
\hline \hline Collection site (NB) & Strain ID & DAOM No. & $\begin{array}{c}\text { Concentration of } \\
\text { griseofulvin (mg/L of } \\
\text { culture) }\end{array}$ \\
\hline \hline Chipman & CH-3 & 242568 & 2.8 \\
Doaktown & DT-1 & 242569 & 0.2 \\
Doaktown & DT-14 & 242775 & 2.0 \\
Doaktown & DT-41 & 242776 & 3.3 \\
Doaktown & DT-53 & & - \\
Saint-George & SG-8 & & - \\
Deersdale & T2-1A-1 & & - \\
Deersdale & T3-1A-2 & 242759 & 4.7 \\
Deersdale & T3-2A-2 & 242761 & 1.1 \\
Deersdale & T3-2B-1 & 242767 & 0.6 \\
Deersdale & T4-2A-3 & 242769 & 4.8 \\
Deersdale & T4-3A-2 & 242770 & 0.1 \\
Deersdale & T5-1B-1 & 242771 & + \\
Deersdale & T5-4B-1 & & - \\
Deersdale & T6-3A-4 & 242772 & 0.01 \\
Deersdale & T6-4A-2 & 242773 & 2.4 \\
Deersdale & T6-4B-2 & 242774 & 9.7 \\
& & &
\end{tabular}

$\mathrm{LOD}=0.7 \mu \mathrm{g} / \mathrm{L}$, "-" = negative for griseofulvin, "+" = positive but below limit of quantitation, $\mathrm{mg} / \mathrm{L}=\mathrm{mg} /$ Glaxo bottle $/ 1 \mathrm{~L}$ of fermentation broth 


\section{DISCUSSION}

It has been established in trees, just as in grasses that the presence of endophytes growing within the plant improves fitness by increasing tolerance to insect or deer herbivory (Miller et al. 2008; Larkin et al. 2012) and may also provide tolerance to fungal pathogens (Ganley et al. 2008).

Todd (1988) demonstrated that a Douglas fir needle endophyte associated with increased tolerance to a needle damaging insect. Working with strains of this fungus from Oregon, Miller reported that extracts were toxic to the spruce budworm (Miller 1986). Research to see if foliar endophytes of conifers in the Acadian Forest shared this toxicity to the spruce budworm began shortly afterwards (Miller 2011). Calhoun et al. (1992) were the first to report on a metabolite isolated from foliar endophytes of balsam fir. Approximately a decade later inoculation of white spruce seedlings with a rugulosin-producing endophyte was shown to affect the growth of spruce budworm larvae. Some of the metabolites of spruce endophytes were also antifungal, including rugulosin (Breen et al. 1955; Sumarah et al. 2008; Sumarah et al. 2010). Extending this work, Sumarah et al. (2011) reported the isolation of antifungal metabolites from endophytes of white pine collected at one site in NB. The present studies extend that work based on a collection from five different sites across south-eastern NB.

A representative selection of this collection was screened for antifungal activity against $S$. cerevisiae and M. violaceum. Ten major metabolites were isolated from two different fungi species, a Xylaria sp. and an unidentified Dothidiomycete possibly representing a new genus and 
species in the family Massarinaceae. In addition, strains of Xylaria species derived from needles that produce the known antifungal compound griseofulvin were found at four of the five sites.

Various species in the Xylariaceae are known to produce a number of metabolites that can be grouped as follows: dihydroisocoumarins and derivatives, succinic acid and derivatives, butyrolactones, cytochalasins, sesquiterpene alcohols, griseofulvin and griseofulvin derivatives, naphthalene derivatives, and long chain fatty acids (Whalley \& Edwards 1999).

Several metabolites have been identified from fungi in the family Massarinaceae, including bioactive Massarilactones $\mathrm{A}$ and $\mathrm{B}$, rosigenin analogues and aromatic polyketides (Oh et al., 1999, 2002, 2003), spiromassaritone and massariphenone (Abdel-Wahab et al., 2007), the antifungal compound keisslone (Liu et al., 2003).

The isolation of metabolites from three antifungal extracts from white pine endophytes yielded the compounds porric acid C (1), 4-hydroxy-5-(hydroxymethyl)-3-methoxy-6-((3prenyloxy)isobenzofuran-1(3H)-one $\quad$ (2), (ethyl 3,6-dimethyl-4-prenyloxy)-2-O- $\beta$-Dglucopyranosyl)benzoate (3) and 5,5'-[oxybis(methylene)]bis-furfuryl alcohol (4) from Xylaria species DAOM 242771 (Figure 37). From an unidentified Dothidiomycete (DAOM 242779 and DAOM 242780) the metabolites (R)-2-methyl-2,3-dihydrobenzofuran-4-carboxylic acid (5), $(R)$-6hydroxy-2-methyl-2,3-dihydrobenzofuran-4-carboxylic acid (6), (R)-5,7-dichloro-6-hydroxy-2methyl-2,3-dihydrobenzofuran-4-carboxylic acid (7), (R)-5,7-dichloro-6-methoxy-2-methyl-2,3- 
dihydrobenzofuran-4-carboxylic acid (8) were isolated, 4-(methoxymethyl)-2-7-dimethyl-9Hxanthene (9), and 6-ethylidenecyclohex-4-ene-1,2,3-triol (10) (Figure 38).

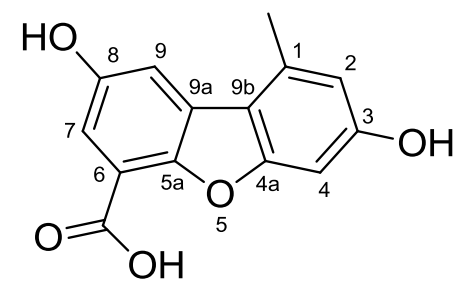

(1)<smiles>OCc1ccc(COc2ccc([Te])o2)o1</smiles><smiles>COc1c(Cl)c2c(c(C(=O)O)c1Cl)C[C@@H](C)O2</smiles>

(8)<smiles>COC1OC(=O)c2cc(OC=C(C)C)c(CO)c(O)c21</smiles>

(2)

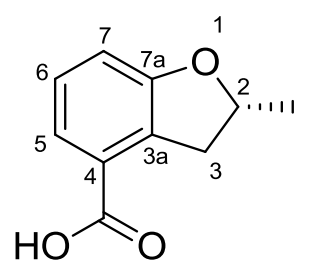

(5)

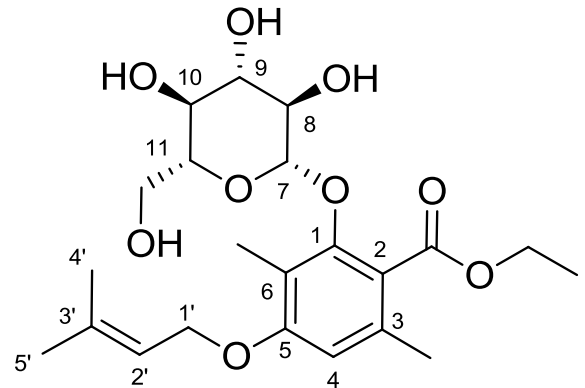

(3)

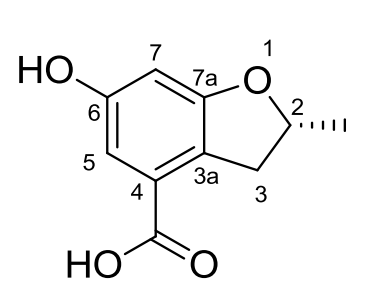

(6)

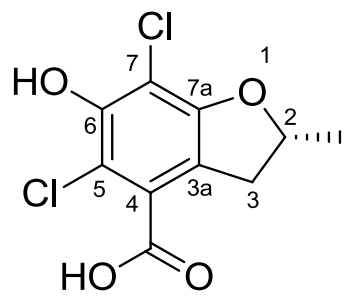

(7)

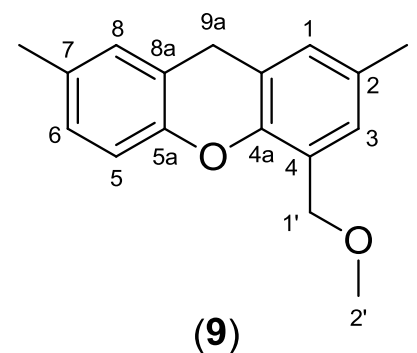<smiles>CC=C1C=C[C@@H](O)[C@H](O)[C]1O</smiles>

(10)

Figure 38: Isolated metabolites (1-10).

Compound 1, porric acid C has previously reported as a phytochemical of garden leek (Allium porrum) (Carotenuto et al. 1997). Compound 4 is a well-known starting material in the synthesis 
of fullerenes and cyclic polyethers (Timko et al. 1977). Compounds 5 and 6 have previously been reported as synthetic intermediates in the synthesis of novel insecticidal $N^{\prime}$-tert-butyl- $N^{\prime}$ benzofuran carbohydrazide derivatives (Huang et al. 2011). The remaining compounds (3-4, and 7-10) are newly described secondary metabolites and are reported here for the first time.

Many of the compounds isolated have a furan or dibenzofuran group as part of their structure (compounds 1-2, and 4-8). Benzofurans and their derivatives are commonly reported metabolites of bacteria and fungi, including endophytes (Findlay et al., 1997; Xia et al., 2011). They are known to have a wide range of bioactivities, including antiproliferative (Chen et al., 2002; Zeng et al., 2012), antitubercular (Huang et al., 2008), anti-insectan (Findlay et al., 1997) and antimicrobial (Boonphong et al., 2007) effects. Due to their biological activities, benzofurans and dihydrobenzofurans have been of the interest to synthetic chemistry (Silveira and Coelho, 2005; Richard et al., 2009). Chlorinated benzofurans are also relatively common as natural products. For example the known antifungal compound griseofulvin which was first isolated from Penicillium griseofulvum (Oxford et al., 1938) and later from a few Xylaria species (Whalley and Edwards, 1995), as well from endophytic Xylaria (Park et al., 2005). Other related chlorinated compounds such as geodin have also been reported (Raistrick and Smith et al., 1936) reported. The dihydrobenzofurans reported here are relatively simple and may be intermediates of metabolites not produced under the conditions tested.

Porric acid C, (1) was reported by Carotenuto et al. (1997) to have an inhibitory effect on the growth of Fusarium culmorum with an ED50 value between 20 and $30 \mu \mathrm{g} / \mathrm{mL}$. In our hands, 
porric acid $\mathrm{C}$ did not display any antifungal activity against $S$. cereivisiae, however it was shown to have an inhibitory effect against the bacteria $B$. subtilis with an MIC of $25.82 \mu \mathrm{g} / \mathrm{mL}$ ( $p=$ 0.003). Compound 2 also exhibited an antibacterial on B. subtilis with an MIC $29.20 \mu \mathrm{g} / \mathrm{mL}$ ( $p=$ $0.005)$.

Compounds 5, 6, 7, and 8 displayed significant bioactivity against the gram positive bacteria $B$. subtilis with a minimum inhibitory concentration (MIC) of $8.91 \mu \mathrm{g} / \mathrm{mL}, 9.71 \mu \mathrm{g} / \mathrm{mL}, 13.15$ $\mu \mathrm{g} / \mathrm{mL}$, and $27.71 \mu \mathrm{g} / \mathrm{mL}$ respectively $(p=0.000, p=0.005, p=0.001$, and $p=0.003$ ).

Substitution of the aromatic moiety of $\mathbf{5}$ with two chlorine atoms and/or a hydroxyl group to give 6, and 7 conserved the bioactivity, whereas methylation of the hydroxyl group (8) reduced the bioactivity slightly leading to higher MIC of $25.5 \mathrm{mg} / \mathrm{L}$. These observations suggest that the degree and nature of substitution are critical for biological activity.

Compound 9 has a xanthene structure. While xanthones (derivatives of $9 H$-xanthen-9-one) are well known as secondary metabolites of fungi, xanthenes are less commonly reported. However, a few have been reported as metabolites of plants (Cao et al. 2007; Masters \& Brase 2011; Shrestha et al. 2011). Their synthesis is an active field since natural product xanthene derivatives have been reported to exhibit anticancer (Chatterjee et al., 1996), snake antivenom (Selvanayagam et al. 1996) and cytotoxic activity (Huang et al., 2010; Giri et al., 2010; Wu et al., 2005). Only one report of a xanthene as a natural product from fungi was identified in the 
literature; paranolin - isolated from Paraphaeosphaeria nolinae (IFB-E011), an endophyte of the wormwood plant Artemisia annua (Ge et al. 2006). Compound 9 is believed to be the first example of a natural product xanthene having an unmodified $9 H$-xanthene skeleton.

An inhibitory effect was also observed for compound 9 against B. subtilis with an MIC of 25.43 $\mu \mathrm{g} / \mathrm{mL}(p=0.000)$. The positive control, chloramphenicol has an MIC of $\leq 8 \mu \mathrm{g} / \mathrm{mL}$ against $B$. subtilis (Citron \& Appleman 2006).

The polyoxygenated derivative reported here (10) is structurally similar to the gabosines, a group of natural products containing a polyhydroxylated methyl cyclohexane system as their basic structure (Bayon \& Figueredo, 2013). Similar compounds have been isolated from bacteria in the genera Streptomyces as well as from fungi, including endophytes, and from plants (Starks et al., 2012; Qin et al. 2010; Venkatasubbaiah et al.1994). Polyoxygenated derivatives having demonstrated various biological activities, including antibacterial properties (Tatsuta et al. 1974), anti-tumor (Kupchan et al., 1969; Takeuchi et al. 1975) and antiproliferative activity on NCIH460 and M14 cancer cells (Starks et al., 2012), as well as antimicrobial activity (Wirasathien et al., 2006). Due to their wide range of biological activities their synthesis is well researched (Shing and Tam, 1998).

A comparison of the metabolites of two different strains of the unidentified Dothidiomycete, strain DAOM 242779 and DAOM 242780, was carried out. Differences in metabolite production 
were observed between the two strains. The xanthene derivative (9) was not isolated or detected in the extract of DAOM 242780; however all of the other compounds were identified in similar quantities (Table 11). Compound 8 was isolated from the extract of DAOM 242780 in abundance, while compound $\mathbf{5}$ was the major metabolite isolated from DAOM 242779.

None of the compounds described (1-10) displayed any growth inhibition against Pseudomonas fluorescens or S. cerevisiae at tested concentrations up to $500 \mu \mathrm{M}$.

Although the crude extract of DAOM 242771 (Xylaria sp.) and those of DAOM 242779 and DAOM 242780 (unidentified Dothidiomycete) were shown to be antifungal against both $S$. cerevisiae and M. violaceum in a paper-disc agar-plate screening assay, none of the compounds isolated displayed antifungal properties. This suggests that either the antifungal metabolites produced by these fungi are very minor and could not be isolated using the procedures described here, or that the antifungal activity observed was due to a combined effect of multiple metabolites acting together.

Griseofulvin was first isolated from Penicillium griseofulvum by Oxford et al. in 1938. However its antifungal properties were not established until later (Brian et al. 1949; Gentles 1958; Blank \& Roth 1969). Griseofulvin has also been isolated as a metabolite of a few Xylaria species, including an endophyte of Abies holophylla (Manchurian fir; Whalley and Edwards, 1995; Park et al., 2005). Griseofulvin is toxic to many plant pathogens including various rusts and is used as 
an antifungal drug to treat dermatophytic infections (Dekker 1963; Blank \& Roth 1969; Aly et al. 1994; Park et al. 2005). The mechanism of action is still unclear, but it was originally thought to affect formation of chitin in the cell wall since only fungi seemed to be affected; however, it is now thought to interfere with microtubule assembly and - influencing cell division and outgrowth of hyphal tips (Borgers 1980; Di Santo 2010).

Griseofulvin was previously isolated from a foliar fungal endophyte of white pine (McFarland 2013) and 16 additional endophyte strains were identified as the same species based on their ITS sequences. These were cultured and the crude extracts were analyzed by LC-MS in MRM mode (Table 12). Thirteen of the seventeen samples were found to contain griseofulvin in amounts ranging from near the detection limit of $0.7 \mu \mathrm{g} / \mathrm{L}$ to $4.8 \mathrm{mg} / \mathrm{L}$ (mean concentration $2.5 \mathrm{mg} / \mathrm{mL}$ ). Yields observed were comparable to those obtained by Oxford et al. $1938(\sim 0.2 \mathrm{mg} / \mathrm{mL})$. Griseofulvin producing Xylaria strains were identified at four of the five collection sites, and all but four of the sixteen strains were found to produce griseofulvin based on LC-MS/MS analysis.

It should be noted that griseofulvin did not display any antifungal activity against $S$. cerevisiae or antibiotic activity against $B$. subtitlis or $P$. fluorescens at concentrations tested up to $500 \mu \mathrm{M}$ in either the paper-disc agar-plate method or the 96-well microplate bioassay. Future work in screening endophytes needs to investigate the use of other bioassay models to ensure that the possibility of identifying bioactive endophyte strains is increased. Additionally, where possible the fractionation process might be aided by an antifungal screening assay. That is to say that following fractionation of the crude extract, each resulting fraction should be screened in the 
same manner as the crude extract. This will ensure that metabolite isolation is carried out on antifungal fractions.

Besides the ten metabolites reported here, other metabolites were present in the extracts, however their structures either remain partially characterized or they were isolated in such limited quantities that characterization was not possible.

So far, the screening of foliar conifer endophytes of white and red spruce, as well as white pine has identified endophytes producing mixtures of highly bioactive compounds. Toxicity of metabolites produced by these strains has been established both in vitro and in vivo (Miller et al. 2002; Sumarah et al. 2008). It has also been established that inoculation of seedlings with these endophytes results in a systemic infection of the seedling (Sumarah et al. 2005). The presence of the endophyte can be measured by monitoring the concentration of toxic secondary metabolites in the needles over time as the tree grows, or it can be measured by enzyme-linked immunosorbent assay (ELISA); using antibodies to detect proteins specific to the endophyte of interest (Sumarah et al. 2005). The measurement of the metabolite in the needles itself, albeit a sensitive technique, is also a very laborious effort since rugulosin is a photo-sensitive compound and chemical extractions must be carried out in darkness.

Recently the development of a quantitative real-time PCR method to detect the presence of the endophyte at levels below the detection limit of the chemical method has been described. Using 
this method it was found that the presence of the endophyte and its secondary metabolite rugulosin were present in the crown of a white spruce tree - thirteen years post inoculation with the endophyte (Frasz et al. in press). This study suggests that the use of endophytes to provide nursery grown seedlings with a natural tolerance towards herbivorous insects and possibly fungal pathogens is promising.

The foliar fungal endophytes of white pine discussed here will be inoculated into seedlings of white pine, and challenged with the fungal pathogen white pine blister rust to determine whether these strains will provide an increased tolerance to the pathogen. 


\section{REFERENCES}

Abdel-Wahab, M. A., Asolkar, R. N., Inderbitzin, P., \& Fenical, W. (2007). Secondary metabolite chemistry of the marine-derived fungus Massarina sp., strain CNT016. Phytochemistry, 68(8), 1212-1218.

Aly, R., Bayles, C., Oakes, R., Bibel, D., \& Maibach, H. (1994). Topical griseofulvin in the treatment of dermatophytoses. Clin. Exp. Dermatol., 19(1), 43-46.

Bacon, C. W., Porter, J. K., Robbins, J. D., \& Luttrell, E. S. (1977). Epichloë typhina from toxic tall fescue grasses. Applied and Environmental Microbiology, 34(5), 576-581.

Balci, M. (2005). 16 -Two-dimensional (2D) NMR spectroscopy. In: M. Balci (Ed.), Basic ${ }^{1} H$ and ${ }^{13} C-N M R$ spectroscopy (pp. 379-406). Amsterdam: Elsevier Science.

Barker, G. M., Pottinger, R. P., Addison, P. J., \& Prestidge, R. A. (1984). Effect of Lolium endophyte fungus infections on behaviour of adult argentine stem weevil. New Zeal. J. Agr. Res., 27, 271-277.

Bayon, P., \& Figueredo, M. (2013). The gabosine and anhydrogabosine family of secondary metabolites. Chem. Rev., 113(7), 4680-4707.

Blank, H. J, Jr., Bruce, W.W., Engel, M.F., Smith, J., Jr., Zaias, N. (1959). The treatment of dermatomycoses with orally administered griseofulvin. A.M.A. Arc. Derm. Syph., 79(3), 259-266.

Boonphong, S., Puangsombat, P., Baramee, A., Mahidol, C., Ruchirawat, S., \& Kittakoop, P. (2007). Bioactive compounds from Bauhinia purpurea possessing antimalarial, antimycobacterial, antifungal, anti-inflammatory, and cytotoxic activities. $J$. Nat. Prod., 70(5), 795-801.

Borgers, M. (1980). Mechanism of action of antifungal drugs, with special reference to the imidazole derivatives. Rev. Infect. Dis., 2(4), 520-534.

Breen, J., Dacre, J. C., Raistrick, H., \& Smith, G. (1955). Studies in the biochemistry of microorganisms. 95. Rugulosin, a crystalline colouring matter of Penicillium rugulosum Thom. Bioch. J., 60(4), 618.

Brian, P. W. (1949). Studies on the biological activity of griseofulvin. Ann. Bot., 13(1), 59-77.

Calhoun, L. A., Findlay, J. A., David Miller, J., \& Whitney, N. J. (1992). Metabolites toxic to spruce budworm from balsam fir needle endophytes. Mycol. Res., 96(4), 281-286.

Cao, J. Q., Yao, Y., Chen, H., Qiao, L., Zhou, Y. Z., \& Pei, Y. H. (2007). A new xanthene from Blumea riparia. Chinese Chem. Lett., 18(3), 303-305. 
Carlile, M. J., Watkinson, S. C., \& Gooday, G. W. (2001). The fungi (2nd ed.). Hungary: Elsevier.

Carotenuto, A., Fattorusso, E., Lanzotti, V., \& Magno, S. (1998). Porric acids A- C- new antifungal dibenzofurans from the bulbs of Allium porrum L. Eur. J. Org. Chem., 1998(4), 661-663.

Carroll, G. C., \& Carroll, F. E. (1978). Studies on the incidence of coniferous needle endophytes in the pacific northwest. Can. J. Bot., 56, 3034-3043.

Chatterjee, S., Iqbal, M., Kauer, J. C., Mallamo, J. P., Senadhi, S., Mallya, S., et al. (1996). Xanthene derived potent nonpeptidic inhibitors of recombinant human calpain I. Bioorg. Med. Chem. Lett., 6(13), 1619-1622.

Chen, C., Chen, C., Shaw, C., Chen, C., \& Tsai, Y. (2002). 2, 3, 4-trimethyl-5, 7-dihydroxy-2, 3dihydrobenzofuran, a novel antioxidant, from Penicillium citrinum F5. J. Nat. Prod., 65(5), 740-741.

Citron, D. M., \& Appleman, M. D. (2006). In vitro activities of daptomycin, ciprofloxacin, and other antimicrobial agents against the cells and spores of clinical isolates of bacillus species. J. Clin. Microbiol., 44(10), 3814-3818.

Clay, K. (1988). Fungal endophytes of grasses: A defensive mutualism between plants and fungi. Ecology, 69, 10-16.

Clay, K. (1987). Effects of fungal endophytes on the seed and seedling biology of Lolium perenne and Festuca arundinacea. Oecologia, 73(3), 358-362.

Cunningham, I. J. (1949). A note on the cause of tall fescue lameness in cattle. Aust. Vet. J., 25, $27-28$.

De Beer, E. J., \& Sherwood, M. B. (1945). The paper-disc agar-plate method for the assay of antibiotic substances. J. Bacteriol., 50(4), 459-467.

Dekker, J. (1963). Antibiotics in the control of plant diseases. Annu. Rev. Microbiol., 17(1), 243262.

Dewick, P. M. (1997). Medicinal natural products: A biosynthetic approach. NY, New York, USA: John Wiley \& Sons.

Di Santo, R. (2010). Natural products as antifungal agents against clinically relevant pathogens. Nat. Prod. Rep., 27(7), 1084-1098.

Frank, B. (1885). Ueber die auf wurzelsymbiose beruhende ernahrung gewisser baume durch unterirdische pilze. Ber. Dt. Bot. Ges.(3), 128-145. 
Findlay, J. A., Buthelezi, S., Li, G., Seveck, M., \& Miller, J. D. (1997). Insect toxins from an endophytic fungus from wintergreen. J. Nat. Prod., 60(11), 1214-1215.

Findlay, J. A., Li, G., Miller, J. D., \& Womiloju, T. O. (2003). Insect toxins from spruce endophytes. Can. J. Chem., 81(4), 284-292.

Finkelstein, E., Amichai, B., \& Grunwald, M. H. (1996). Griseofulvin and its uses. Int. J. Antimicrob. Ag., 6(4), 189-194.

Frasz, S. L., Walker, A. K., Nsiama, T. K., Adams, G. W., \& Miller, J. D. (In Press). Distribution of the foliar fungal endophyte phialocephala scopiformis and its toxin in the crown of a 13 year old white spruce tree as revealed by chemical and qPCR analyses. Can. J. Forest Res.

Frisvad, J. C., Andersen, B., \& Thrane, U. (2008). The use of secondary metabolite profiling in chemotaxonomy of filamentous fungi. Mycol. Res., 112(2), 231-240.

Frisvad, J. C. (1987). High-performance liquid chromatographic determination of profiles of mycotoxins and other secondary metabolites. J. Chromatogr. A, 392, 333-347.

Frisvad, J. C., \& Thrane, U. (1987). Standardized high-performance liquid chromatography of 182 mycotoxins and other fungal metabolites based on alkylphenone retention indices and UV_-VIS spectra (diodearray detection). . Chromatogr. A, 404, 195-214.

Funk, C. R., Halisky, P. M., Johnson, M. C., Siegel, M. R., Stewart, A. V., Ahmad, S., et al. (1983). An endophytic fungus and resistance to sod webworms: Association in Lolium perenne L. Nat Biotech, 1(2), 189-191.

Funk, C. R., \& White, J., Jr. (1997). Use of natural and transformed endophytes for turf improvement. In: C. Bacon, \& N. Hill (Eds.), (pp. 229-239) Springer US.

Gallagher, R. T., White, E. P., \& Mortimer, P. H. (1981). Ryegrass staggers: Isolation of potent neurotoxins lolitrem A and lolitrem B from staggers-producing pastures. New Zeal. Vet. J., 29(10), 189-190.

Ganley, R. J., Sniezko, R. A., \& Newcombe, G. (2008). Endophyte-mediated resistance against white pine blister rust in Pinus monticola. Forest Ecol. Manag., 255(7), 2751-2760.

Ge, H. M., Song, Y. C., Chen, J. R., Hu, S., Wu, J. Y., \& Tan, R. X. (2006). Paranolin: A new Xanthene-Based metabolite from Paraphaeosphaeria nolinae. Helv. Chim. Acta, 89(3), 502506.

Gentles, J. (1958). Experimental ringworm in guinea pigs: Oral treatment with griseofulvin. Nature, 476-477.

Gilruth, J. A. (1906). Meningo-encephalitis (stomach staggers) of horses, cattle and sheep. Ann. Rep. N.Z. Dept. Agri., 14, 293-297. 
Giri, R., Goodell, J. R., Xing, C., Benoit, A., Kaur, H., Hiasa, H., et al. (2010). Synthesis and cancer cell cytotoxicity of substituted xanthenes. Bioorgan. Med. Chem., 18(4), 1456-1463.

Hanson, J. R. (2003). The classes of natural product and their isolation. In: Natural Products: The Secondary Metabolites (pp. 1-34). The Royal Society of Chemistry.

Harris, D. C. (2003). Quantitative chemical analysis (6th ed.). New York: W. H. Freeman and Company.

Huang, L., Lei, T., Lin, C., Kuang, X., Chen, H., \& Zhou, H. (2010). Blumeaxanthene II, a novel xanthene from Blumea riparia DC. Fitoterapia, 81(5), 389-392.

Huang, Z., Liu, Y., Li, Y., Xiong, L., Cui, Z., Song, H., et al. (2011). Synthesis, crystal structures, insecticidal activities, and Structural Activity relationships of novel N'-tert-butylN'-substituted-benzoyl-N-di(octa)hydro]benzofuran $\{(2,3-$ dihydro)benzo1,3](1,4])dioxine \} carbohydrazide derivatives. J. Agr. Food Chem., 59(2), 635-644.

Hyde, K. D., \& Soytong, K. (2008). The fungal endophyte dilemma. Fungal Divers., 33, 163173.

Joost, R. E. (1995). Acremonium in fescue and ryegrass: Boon or bane? A review. J. Anim. Sci., 73(3), 881-888.

Kebarle, P., \& Verker, U. H. (2010). On the mechanism of electrospray ionization mass spectrometry (ESIMS). In: R. B. Cole (Ed.), Electrospray and MALDI mass spectrometry: Fundamentals, instrumentation, practicalities, and biological applications (2nd ed., pp. 348). Hoboken, NJ, USA: John Wiley \& Sons.

Larkin, B. G., Hunt, L. S., \& Ramsey, P. W. (2012). Foliar nutrients shape fungal endophyte communities in western white pine (Pinus monticola) with implications for white-tailed deer herbivory. Fungal Ecol., 5(2), 252-260.

Lewis, F. J. (1924). An endotropic fungus in the Coniferae. Nature, 114, 860.

Liu, C., Liu, J., Huang, L., Zou, W., \& Tan, R. (2003). Absolute configuration of keisslone, a new antimicrobial metabolite from keissleriella sp. YS4108, a marine filamentous fungus. Planta Med., 69(5), 481-482.

Lyons, P. C., Plattner, R. D., \& Bacon, C. W. (1986), Occurrence of peptide and clavine ergot alkaloids in tall fescue grass. (Washington, D.C.) 1986,232, 487-489. Science, 232, 487489.

Manitto, P. (1981). Primary and secondary metabolism. In: P. G. Sammes (Ed.), Biosynthesis of natural products (pp. 9-50) Ellis Horwood. 
Masters, K., \& Brâse, S. (2012). Xanthones from fungi, lichens, and bacteria: The natural products and their synthesis. Chem. Rev., 112(7), 3717-3776.

Miller, J. D. (2011). Foliar endophytes of spruce species found in the Acadian forest: Basis and potential for improving the tolerance of the forest to spruce budworm. In: A. M. Pirttila, \& F. A. Carolin (Eds.), Endophytes of forest trees: Biology and applications. New York: Springer.

Miller, J. (1986). Toxic metabolites of epiphytic and endophytic fungi of conifer needles. Microbiology of the phyllosphereledited by NJ Fokkema and J.Van Den Heuvel.

Miller, J. D., Cherid, H., Sumarah, M. W., \& Adams, G. W. (2009). Horizontal transmission of the Picea glauca foliar endophyte Phialocephala scopiformis CBS 120377. Fungal Ecol., 2(2), 98-101.

Miller, J. D., Mackenzie, S., Foto, M., Adams, G. W., \& Findlay, J. A. (2002). Needles of white spruce inoculated with rugulosin-producing endophytes contain rugulosin reducing spruce budworm growth rate. Mycol. Res., 106(4), 471-479.

Miller, J. D., Sumarah, M., \& Adams, G. (2008). Effect of a rugulosin-producing endophyte in Picea glauca on Choristoneura fumiferana. J. Chem. Ecol., 34(3), 362-368.

Mortimer, P. H., Fletcher, L. R., di Menna, M. E., Harvey, I. C., Smith, G. S., Barker, G. M., et al. (1982). Recent advances in ryegrass staggers research. Proc. Ruakura Farmers Conf., 34, 71-74.

Natural Resources Canada. (2011). Important facts on Canada's natural resources: Forests. Retrieved on 2013-01-25, <http://www.nrcan.gc.ca/statistics-facts/forests/897>., 2013.

Neill, J. C. (1940). The endophyte of ryegrass (Lolium perenne). New Zeal. J. Sci. Tech., A21, 280-291.

Oh, H., Gloer, J. B., \& Shearer, C. A. (1999). Massarinolins AC: New bioactive sesquiterpenoids from the aquatic fungus Massarina tunicata. J. Nat. Prod., 62(3), 497-501.

Oh, H., Swenson, D. C., Gloer, J. B., \& Shearer, C. A. (2001). Massarilactones A and B: Novel secondary metabolites from the freshwater aquatic fungus Massarina tunicata. Tet. Lett., 42(6), 975-977.

Oh, H., Swenson, D. C., Gloer, J. B., \& Shearer, C. A. (2003). New bioactive rosigenin analogues and aromatic polyketide metabolites from the freshwater aquatic fungus Massarina tunicata. J. Nat. Prod., 66(1), 73-79. 
Oses, R., Valenzuela, S., Freer, J., Sanfuentes, E., \& Rodriguez, J. (2008). Fungal endophytes in xylem of healthy Chilean trees and their possible role in early wood decay. Fungal Divers., 33, 77-86.

Oxford, A. E., Raistrick, H., \& Simonart, P. (1939). Studies in the biochemistry of microorganisms: Griseofulvin, $\mathrm{C}_{17} \mathrm{H}_{17} \mathrm{O}_{6} \mathrm{Cl}$, a metabolic product of Penicillium griseo-fulvum dierckx. Biochem. J., 33(2), 240-248.

Park, J. H., Choi, G. J., Lee, H. B., Kim, K. M., Jung, H. S., Lee, S. -., et al. (2005). Griseofulvin from Xylaria sp. strain F0010, an endophytic fungus of Abies holophylla and its antifungal activity against plant pathogenic fungi. J. Microbiol. Biotechn., 15(1), 112-117.

Pavia, Donald L., Lampman, Gary M., Kriz, George S., and James R. Vyvyan. (2009). Introduction to spectroscopy (Fourth ed.). Belmont, CA, USA: Brooks/Cole.

Pulsford, M. F. (1950). A note on lameness in cattle grazing on tall meadow fescue (Festuca arundinacea) in South Australia. Aust. Vet. J., 26, 87-88.

Qin, S., Hussain, H., Schulz, B., Draeger, S., \& Krohn, K. (2010). Two new metabolites, epoxydine A and B, from Phoma sp. Helv. Chim. Acta, 93(1), 169-174.

Raistrick, H., \& Smith, G. (1936). Studies in the biochemistry of micro-organisms: The metabolic products of Aspergillus terreus thom. part II. Two new chlorine-containing mould metabolic products, geodin and erdin. Biochem. J., 30(8), 1315-1322.

Romero, Y., Richard, F., Reneme, Y., \& Brunet, S. (2009). Hydrodeoxygenation of benzofuran and its oxygenated derivatives (2,3-dihydrobenzofuran and 2-ethylphenol) over NiMoP/ $/ \mathrm{Al}_{2} \mathrm{O}_{3}$ catalyst. App. Catal. A-Gen., 353(1), 46-53.

Sampson, K. (1933). The systemic infection of grasses by Epichloe typhina (pers.) tul. Transactions of the British Mycological Society, $18(1), 30$.

Schmidt, S. P., \& Osborn, T. G. (1993). Effects of endophyte-infected tall fescue on animal performance. Agr. Ecosys. Env., 44(1-4), 233-262.

Schoch, C. L., Seifert, K. A., Huhndorf, S., Robert, V., Spouge, J. L., Levesque, C. A., et al. (2012). Nuclear ribosomal internal transcribed spacer (ITS) region as a universal DNA barcode marker for fungi. P. Nat. Acad. Sci. USA.

Selvanayagam, Z., Gnanavendhan, S., Balakrishna, K., Rao, R., Sivaraman, J., Subramanian, K., et al. (1996). Ehretianone, a novel quinonoid xanthene from Ehretia buxifolia with antisnake venom activity. J. Nat. Prod., 59(7), 664-667.

Shing, T. K., \& Tam, E. K. (1998). Enantiospecific syntheses of (+)-crotepoxide, $(+)-$ boesenoxide, $(+)-\beta$-senepoxide, $(+)$-pipoxide acetate, $(-)$-iso-crotepoxide, $(-)$-senepoxide, and (-)-tingtanoxide from (-)-quinic Acid1. J. Org. Chem., 63(5), 1547-1554. 
Smedsgaard, J., \& Nielsen, J. (2005). Metabolite profiling of fungi and yeast: From phenotype to metabolome by MS and informatics. J. Exp. Bot., 56(410), 273-286.

Shrestha, S., Park, J., Lee, D., Cho, J., Cui, E., Chung, I., et al. (2011). A new xanthene from desmostachya bipinnata (L.) stapf inhibits signal transducer and activator of transcription 3 (STAT3) and low-density lipoprotein-oxidation. J. Korean Soc. App. Biol. Chem., 54(2), 308-311.

Silveira, G. P., \& Coelho, F. (2005). Enantioselective synthesis of 2-ethyl-2, 3dihydrobenzofuran carboxylic acid, direct precursor of (+)-efaroxan, from a Baylis-Hillman adduct. Tet. Lett., 46(38), 6477-6481.

Starks, C. M., Williams, R. B., Rice, S. M., Norman, V. L., Lawrence, J. A., Goering, M. G., et al. (2012). Polyoxygenated cyclohexene derivatives from monanthotaxis congoensis. Phytochemistry, 74(0), 185-189.

Sumarah, M. W., Miller, J. D., \& Adams, G. W. (2005). Measurement of a rugulosin-producing endophyte in white spruce seedlings. Mycologia, 97(4), 770-776.

Sumarah, M. W., Puniani, E., Blackwell, B. A., \& Miller, J. D. (2008). Characterization of polyketide metabolites from foliar endophytes of Picea glauca. J. Nat. Prod., 71(8), 13931398.

Sumarah, M. W., Adams, G. W., Berghout, J., Slack, G. J., Wilson, A. M., \& Miller, J. D. (2008). Spread and persistence of a rugulosin-producing endophyte in Picea glauca seedlings. Mycol. Res., 112(6), 731-736.

Sumarah, M. W., Puniani, E., Sørensen, D., Blackwell, B. A., \& Miller, J. D. (2010). Secondary metabolites from anti-insect extracts of endophytic fungi isolated from Picea rubens. Phytochemistry, 71(7), 760-765.

Sumarah, M. W., Kesting, J. R., Sørensen, D., \& Miller, J. D. (2011). Antifungal metabolites from fungal endophytes of Pinus strobus. Phytochemistry, 72(14), 1833-1837.

Sumarah, M. W., Walker, A. K., Seifert, K. A., Todorov, A., \& Miller, J. D. (submitted). Screening of fungal endophytes isolated from eastern white pine needles. Phytochem. Lett.,

Timko, J. M., Moore, S. S., Walba, D. M., Hiberty, P. C., \& Cram, D. J. (1977). Host-guest complexation. 2. Structural units that control association constants between polyethers and tert-butylammonium salts. J. Am. Chem. Soc., 99(13), 4207-4219.

Todd, D. (1988). The effects of host genotype, growth rate, and needle age on the distribution of a mutualistic, endophytic fungus in Douglas-fir plantations. Can. J. Forest Res., 18(5), 601605.

Werner, D. (1992). Symbiosis of plants and microbes. London: Chapman \& Hall. 
Venkatasubbaiah, P., Tisserat, N. A., \& Chilton, W. S. (1994). Metabolites of Ophiosphaerella herpotricha, a cause of spring dead spot of bermudagrass. Mycopathologia, 128(3), 155159.

Whalley, A., \& Edwards, R. (1995). Secondary metabolites and systematic arrangement within the Xylariaceae. Can. J. Bot., 73(S1), 802-810.

West, C. P., Izekor, E., Oosterhuis, D. M., \& Robbins, R. T. (1988). The effect of Acremonium coenophialum on the growth and nematode infestation of tall fescue. Plant Soil, 112(1), 3-6.

Wilson, R., Wheatcroft, R., Miller, J. D., \& Whitney, N. J. (1994). Genetic diversity among natural populations of endophytic Lophodermium pinastri from Pinus resinosa. Mycol. Res., 98(7), 740-744.

Wirasathien, L., Pengsuparp, T., Moriyasu, M., Kawanishi, K., \& Suttisri, R. (2006). Cytotoxic C-benzylated chalcone and other constituents of Ellipeiopsis cherrevensis. Arch. Pharm. Res., 29(6), 497-502.

Wu, C., Van Schalkwyk, D. A., Taylor, D., Smith, P. J., \& Chibale, K. (2005). Reversal of chloroquine resistance in Plasmodium falciparum by $9-H$-xanthene derivatives. Int. $J$. Antimicrob. Ag., 26(2), 170-175.

Xia, X., Li, Q., Li, J., Shao, C., Zhang, J., Zhang, Y., et al. (2011). Two new derivatives of griseofulvin from the mangrove endophytic fungus Nigrospora sp. (strain no. 1403) from Kandelia candel (L.) druce. Planta Medica, 77(15), 1735-1738.

Xu, F., Zhang, Y., Wang, J., Pang, J., Huang, C., Wu, X., et al. (2008). Benzofuran derivatives from the mangrove endophytic fungus Xylaria sp.(\# 2508). J. Nat. Prod., 71(7), 1251-1253.

Zeng, X., Wang, Y., Qiu, Q., Jiang, C., Jing, Y., Qiu, G., et al. (2012). Bioactive phenolics from the fruits of Livistona chinensis. Fitoterapia, 83(1), 104-109. 
APPENDIX I - MASS SPECTRA, AND ${ }^{1} \mathrm{H}$ AND ${ }^{13} \mathrm{C}$ NMR FOR COMPOUNDS ISOLATED 


\section{COMPOUND 1 (Porric acid C)}

Mass spectrum of compound $\mathbf{1}$

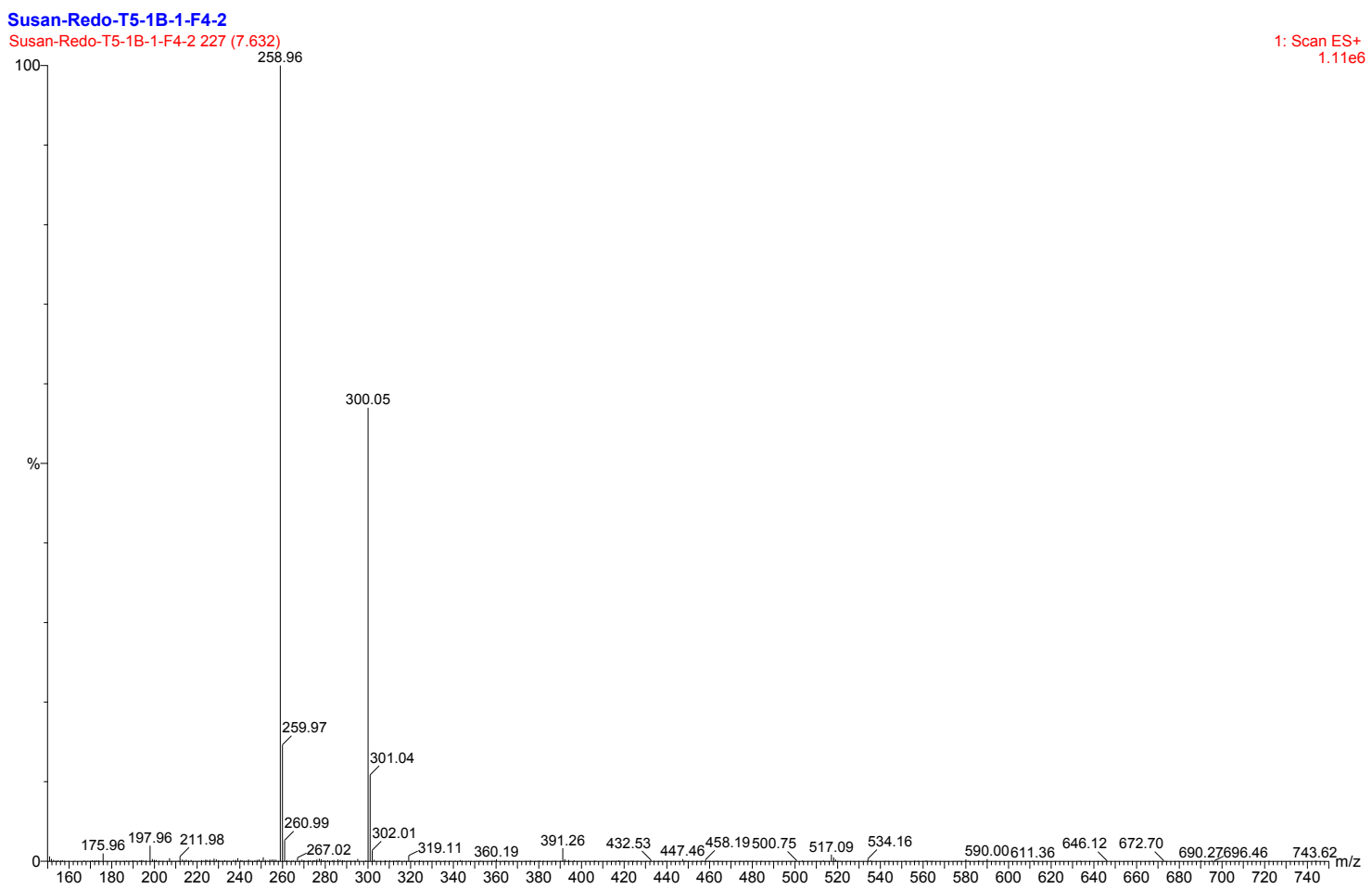

${ }^{1} \mathrm{H}-\mathrm{NMR}$ spectrum of compound $\mathbf{1}\left(\left(\mathrm{CH}_{3}\right)_{2} \mathrm{CO}, 700 \mathrm{MHz}\right)$

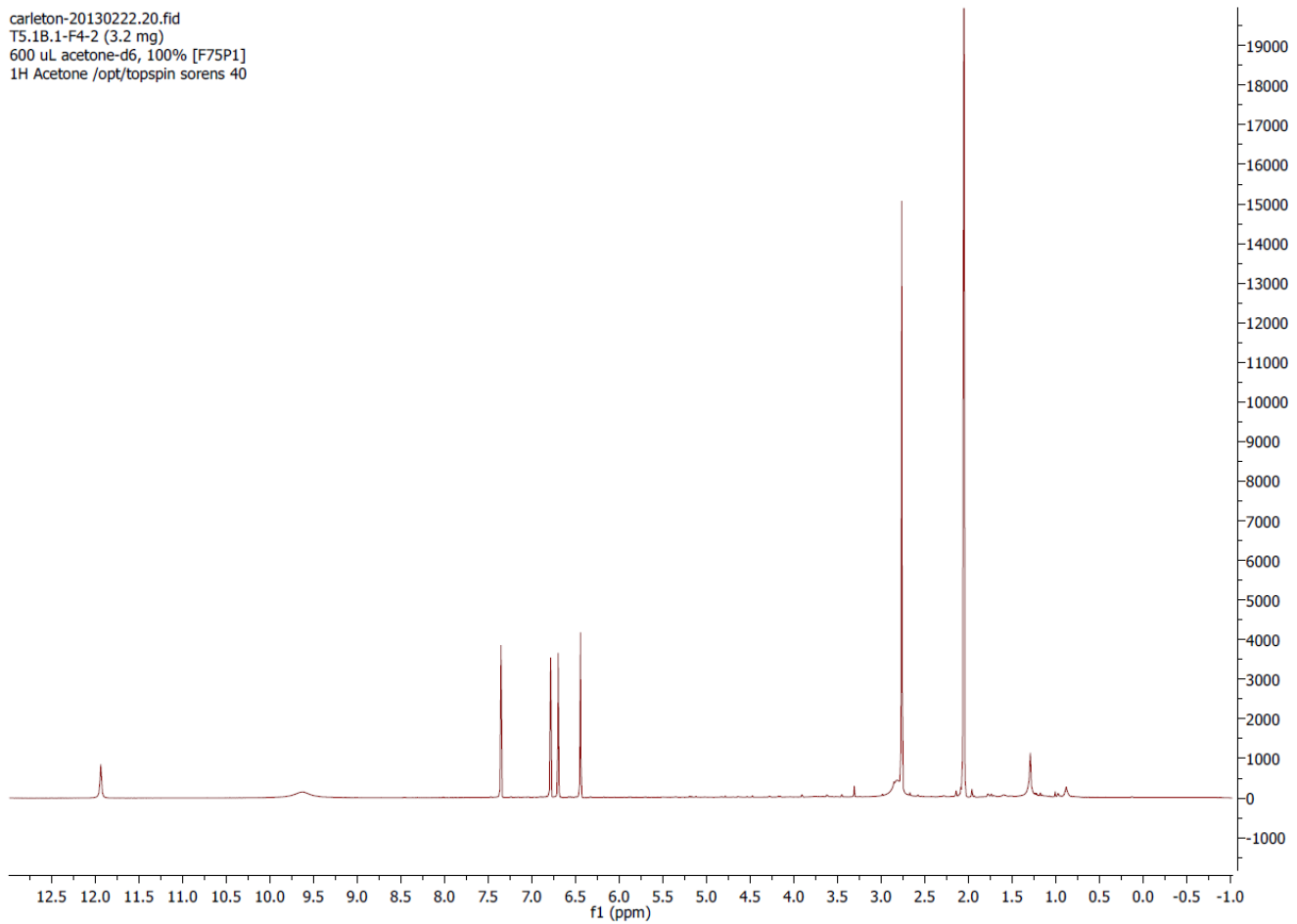


${ }^{13} \mathrm{C}$-NMR spectrum of compound $\mathbf{1}\left(\left(\mathrm{CH}_{3}\right)_{2} \mathrm{CO}, 176 \mathrm{MHz}\right)$

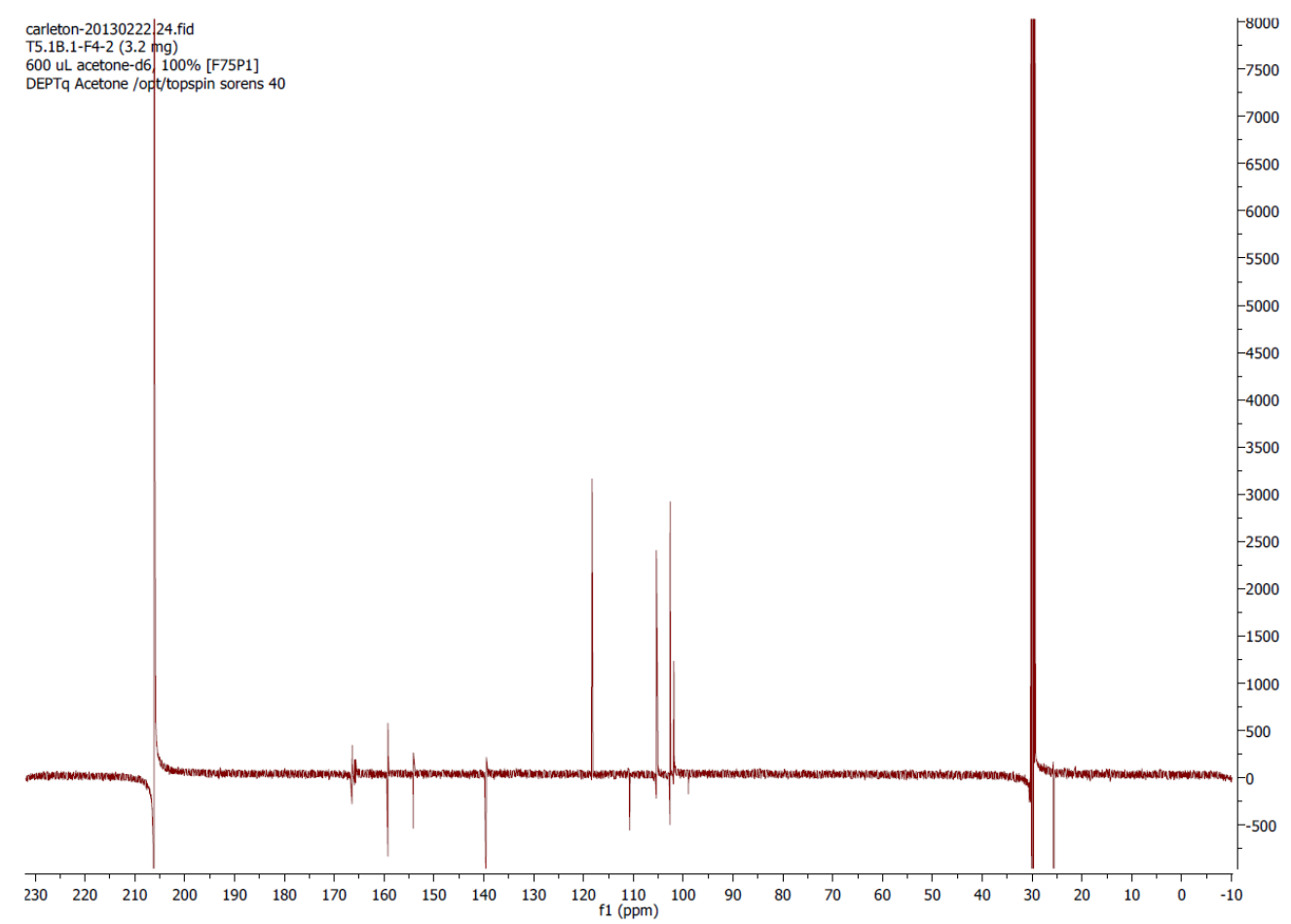

HSQC of compound $1\left(\left(\mathrm{CH}_{3}\right)_{2} \mathrm{CO}, 700 \mathrm{MHz}\right)$

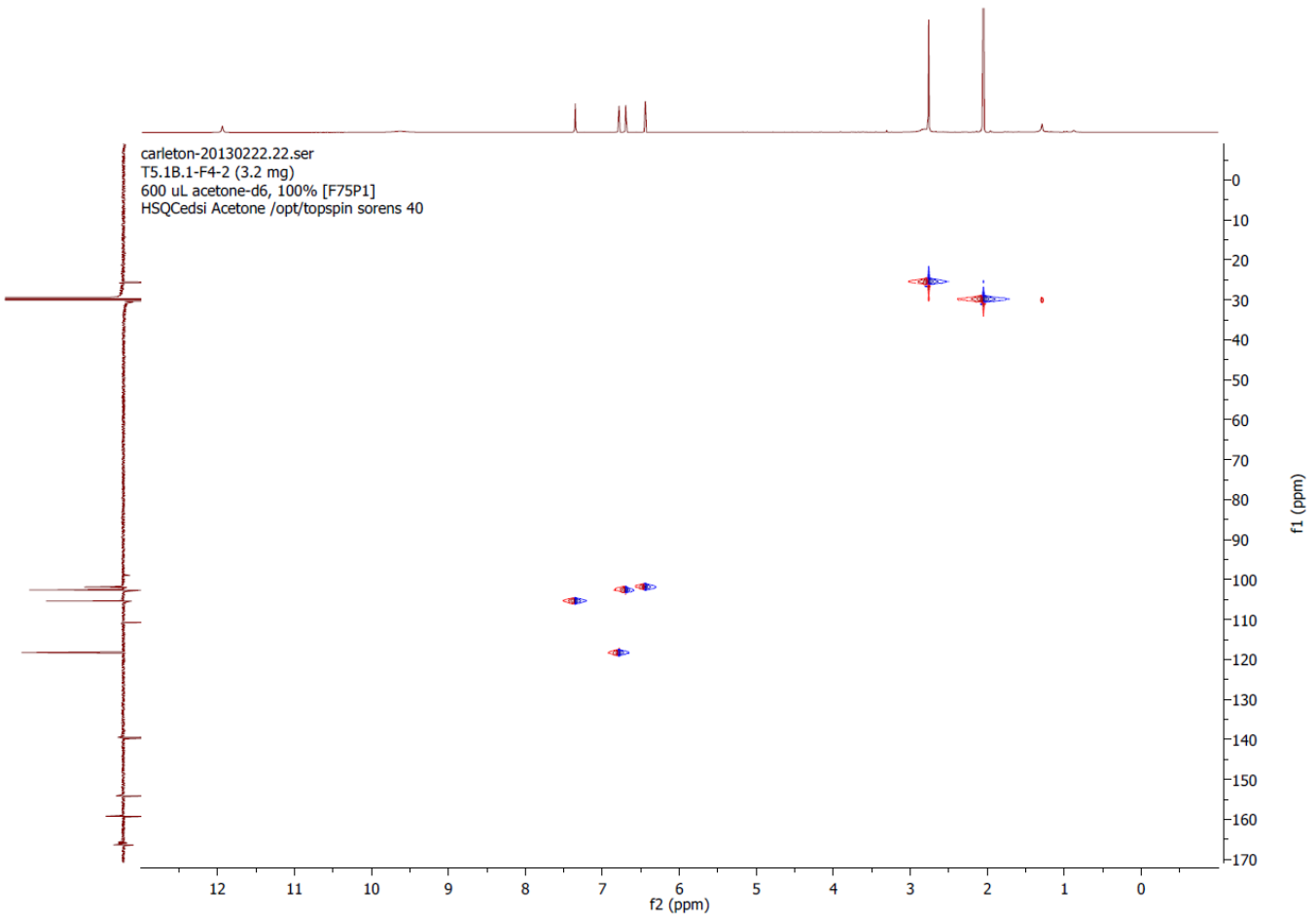


HMBC of compound $1\left(\left(\mathrm{CH}_{3}\right)_{2} \mathrm{CO}, 700 \mathrm{MHz}\right)$

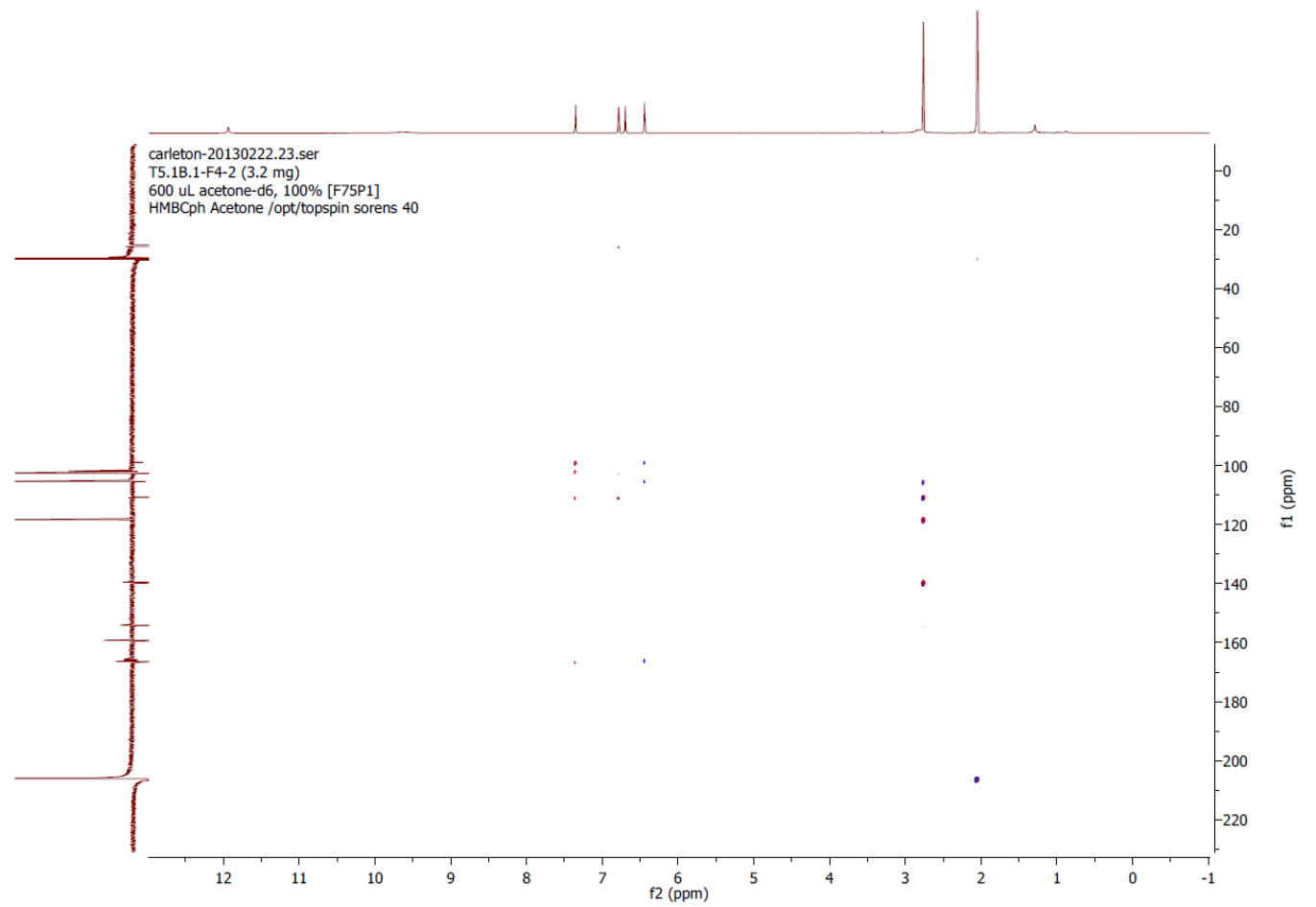

COSY spectrum of $\mathbf{1}\left(\left(\mathrm{CH}_{3}\right)_{2} \mathrm{CO}, 700 \mathrm{MHz}\right)$

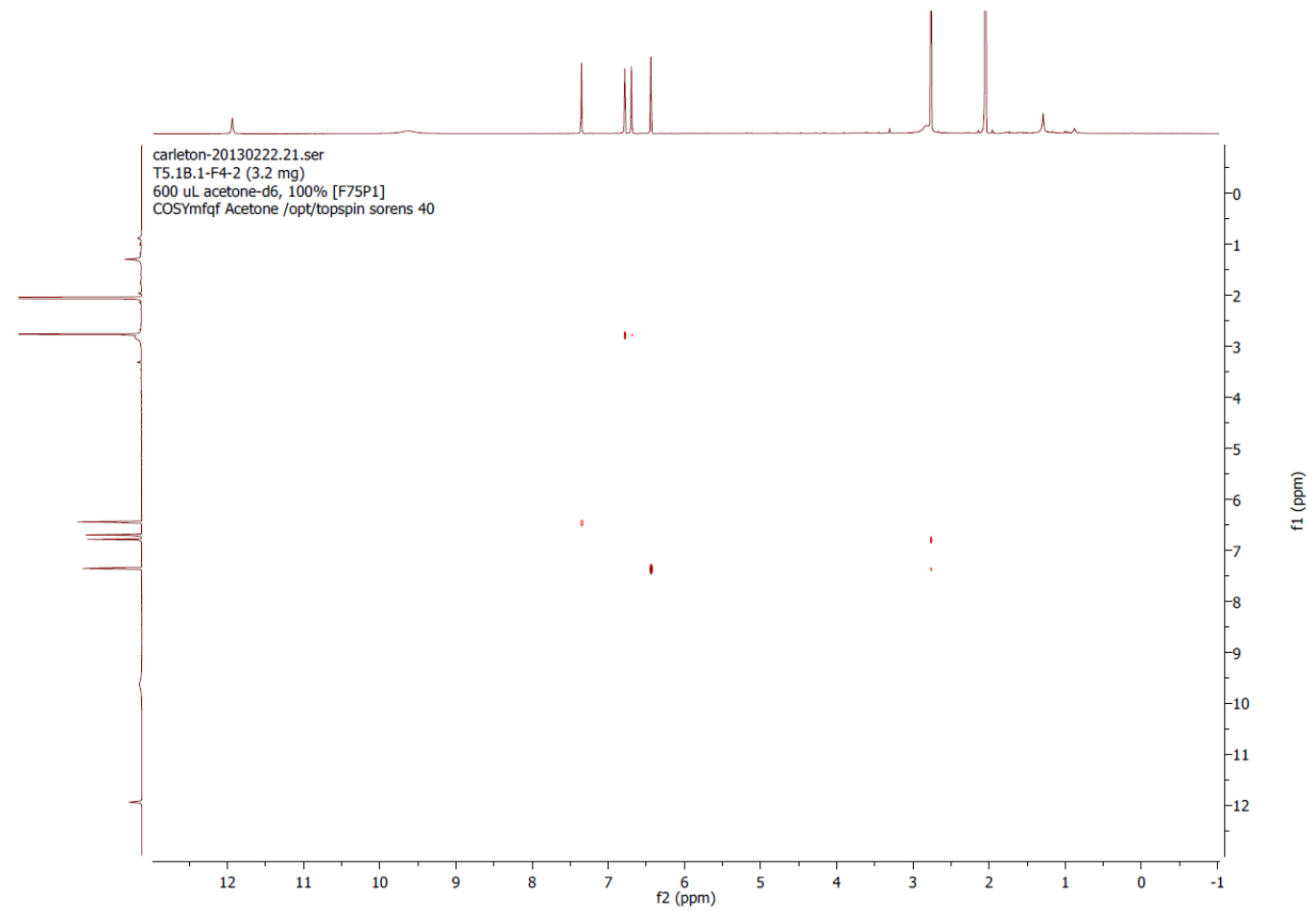


COMPOUND 2 (4-hydroxy-5-(hydroxymethyl)-3-methoxy-6-((3-prenyloxy)isobenzofuran1(3H)-one)

Mass spectrum of compound 2

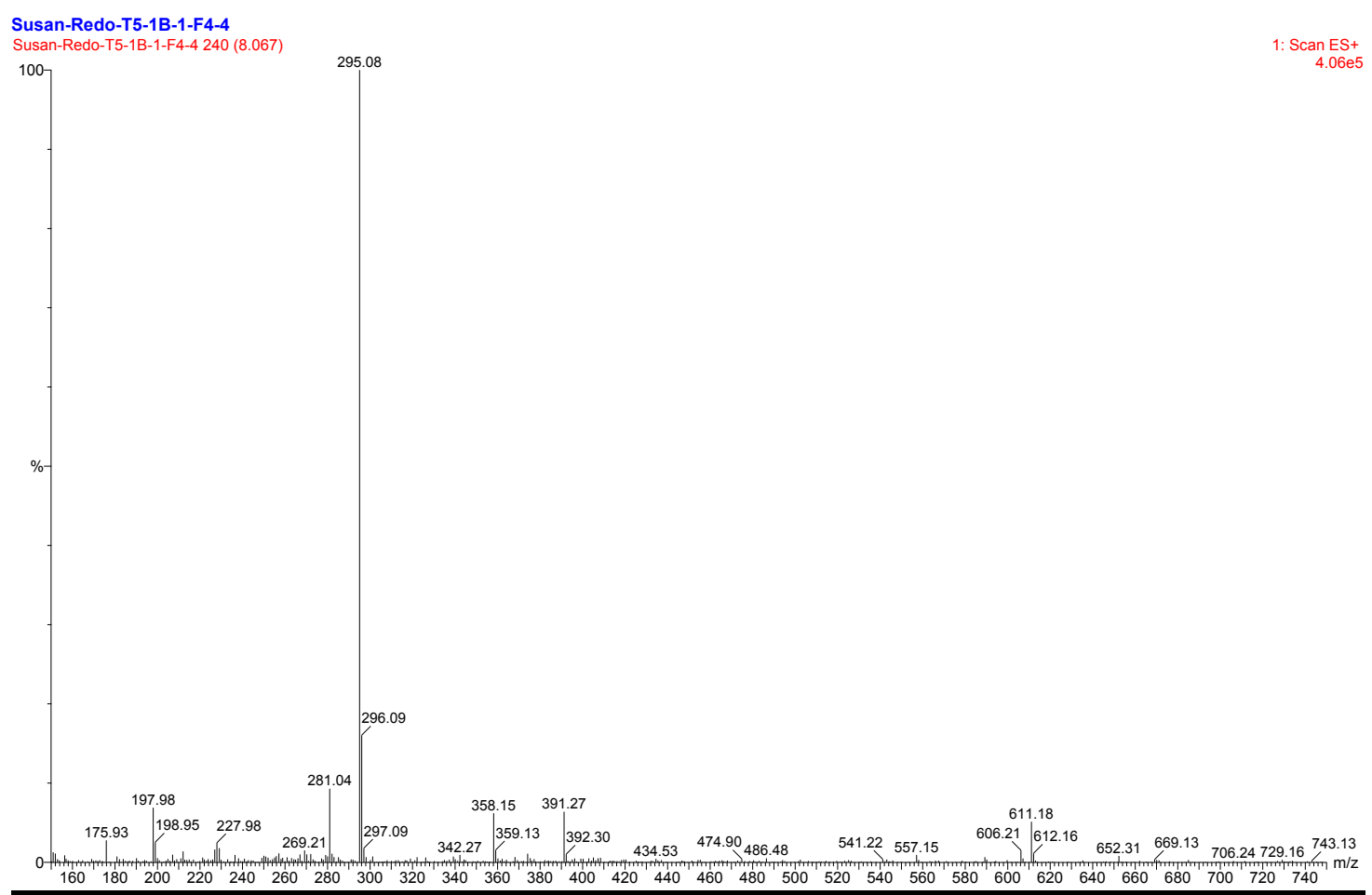

${ }^{1} \mathrm{H}-\mathrm{NMR}$ spectrum of compound $2\left(\left(\mathrm{CH}_{3}\right)_{2} \mathrm{CO}, 700 \mathrm{MHz}\right)$

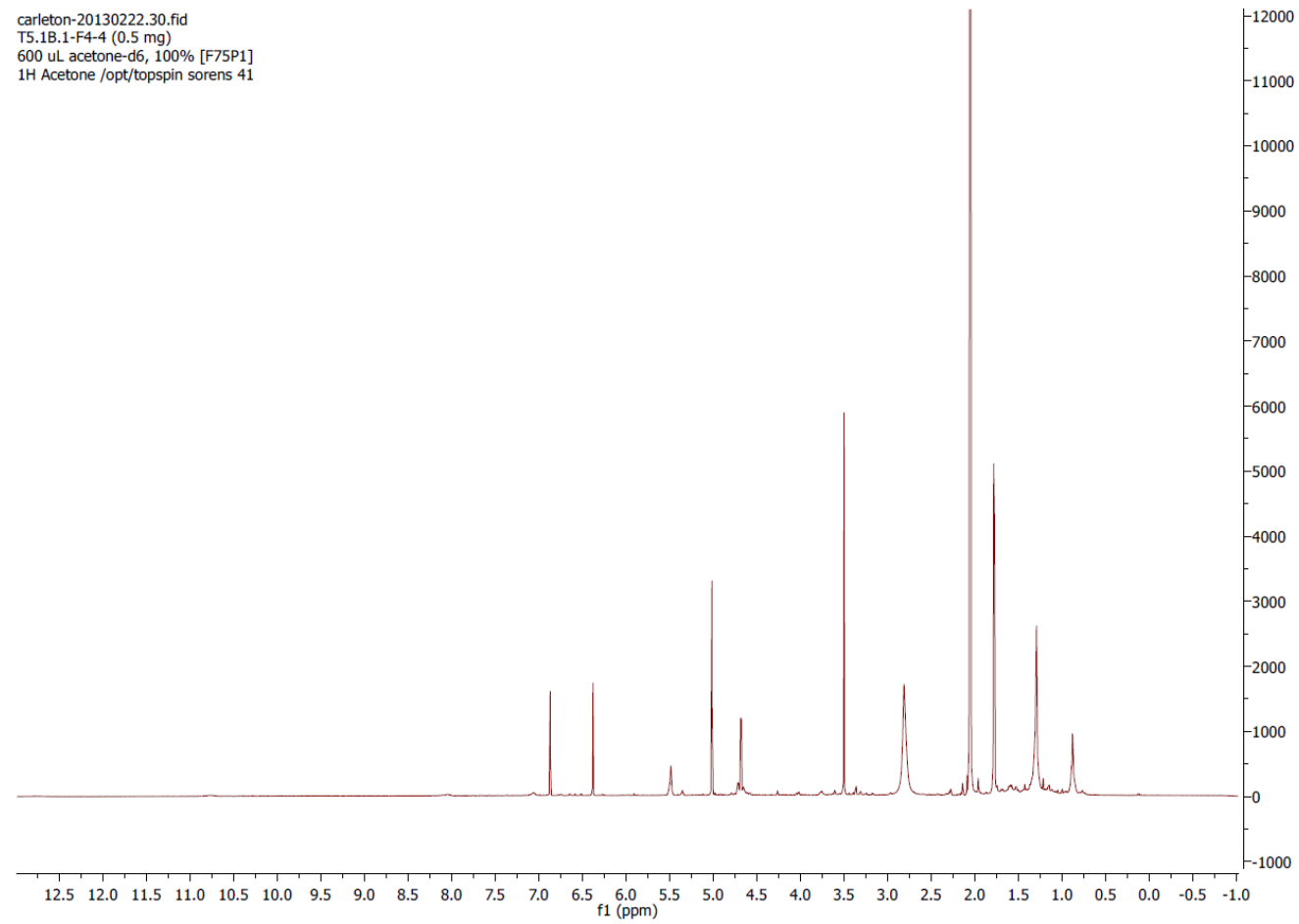


${ }^{13} \mathrm{C}$-NMR spectrum of compound $2\left(\left(\mathrm{CH}_{3}\right)_{2} \mathrm{CO}, 176 \mathrm{MHz}\right)$

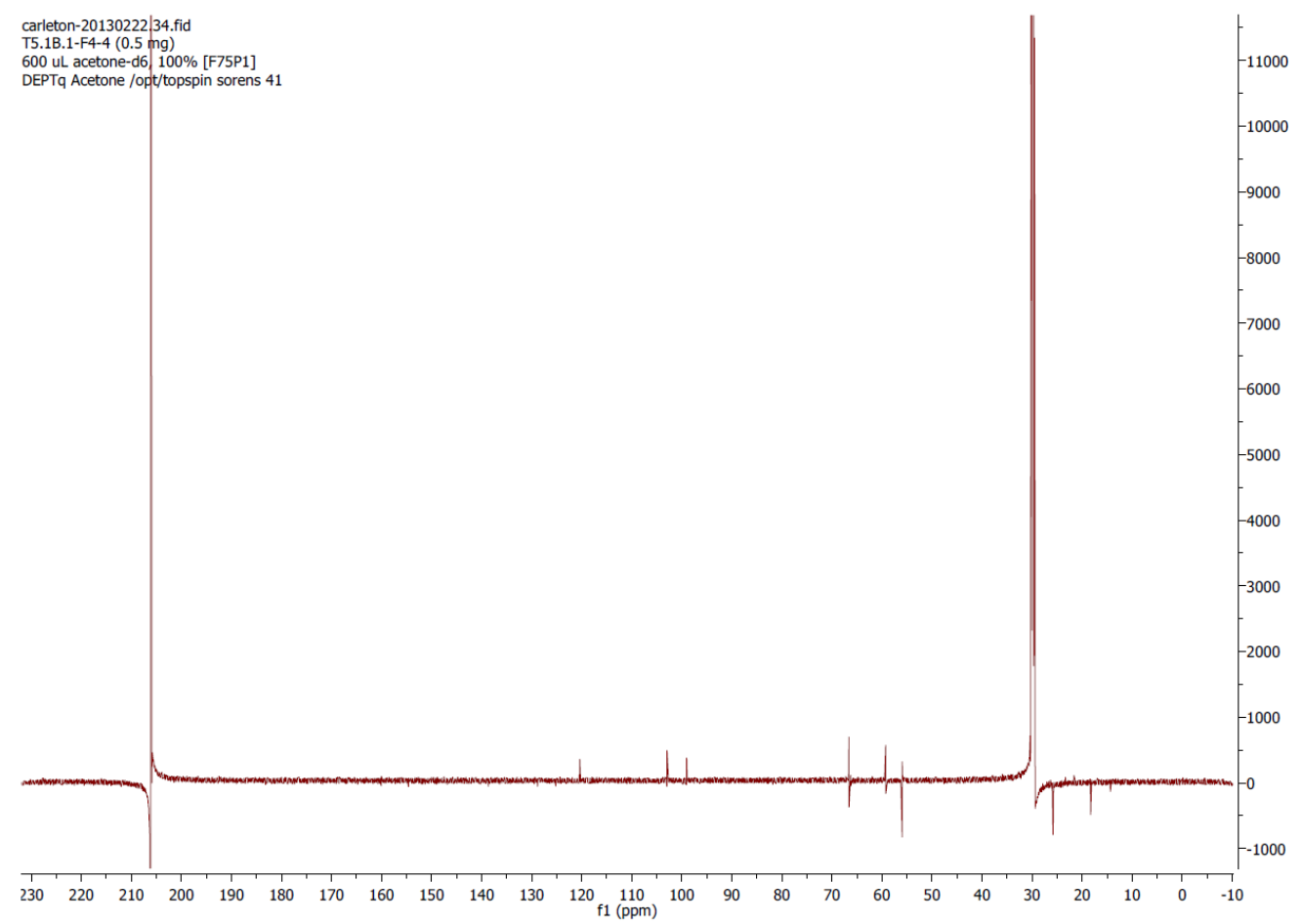

HSQC of compound $2\left(\left(\mathrm{CH}_{3}\right)_{2} \mathrm{CO}, 700 \mathrm{MHz}\right)$

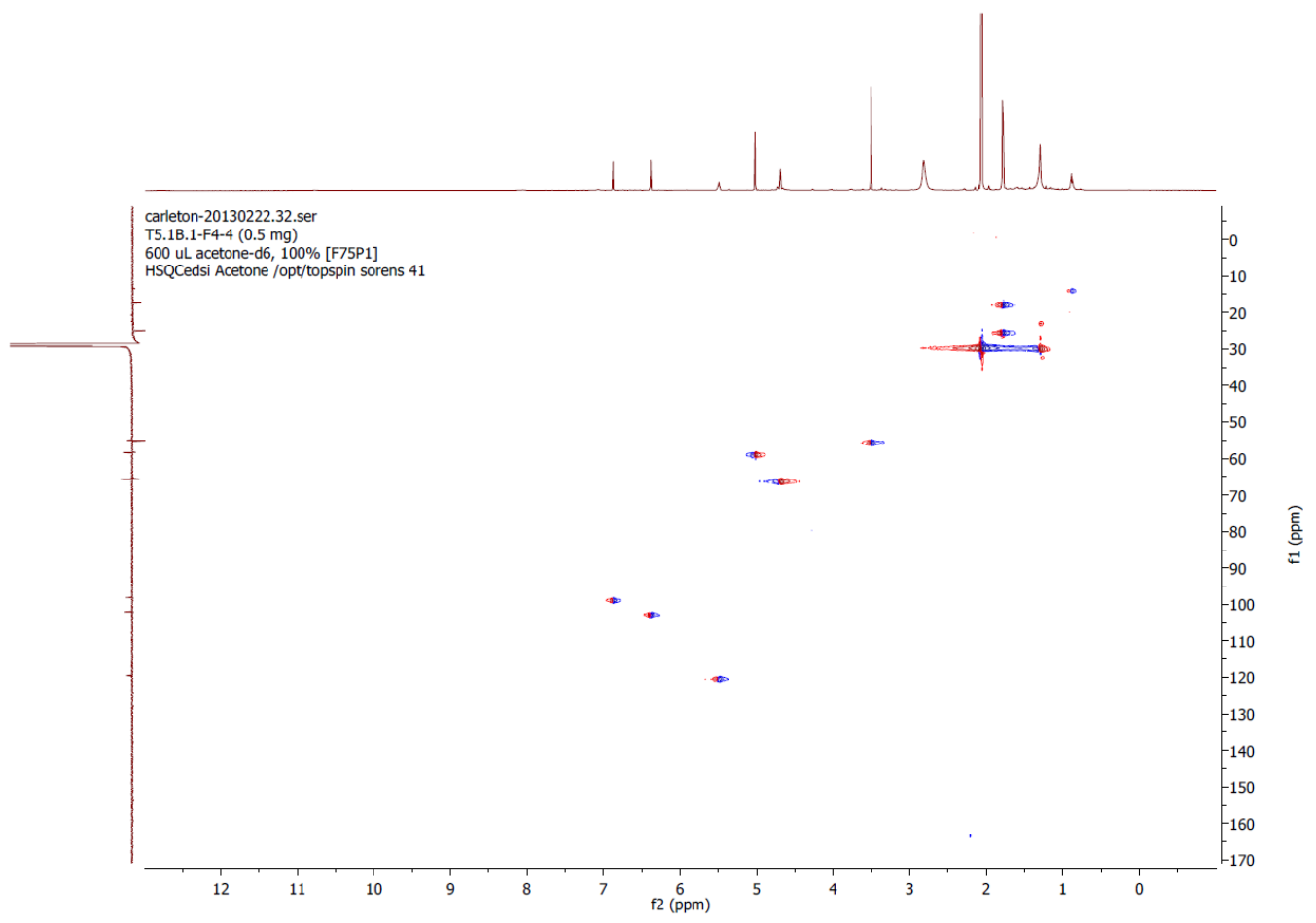


HMBC of compound $2\left(\left(\mathrm{CH}_{3}\right)_{2} \mathrm{CO}, 700 \mathrm{MHz}\right)$

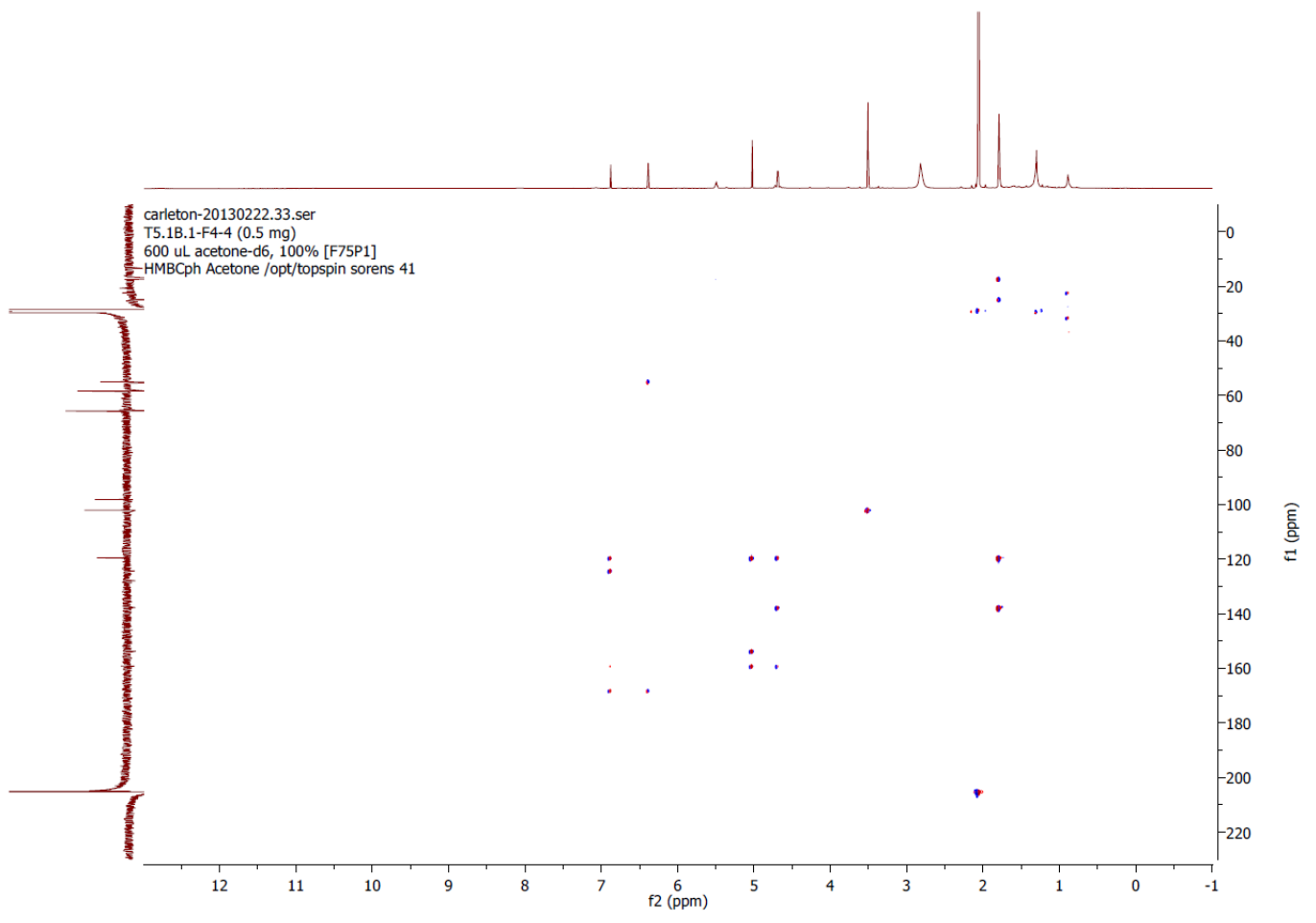

COSY spectrum of $2\left(\left(\mathrm{CH}_{3}\right)_{2} \mathrm{CO}, 700 \mathrm{MHz}\right)$

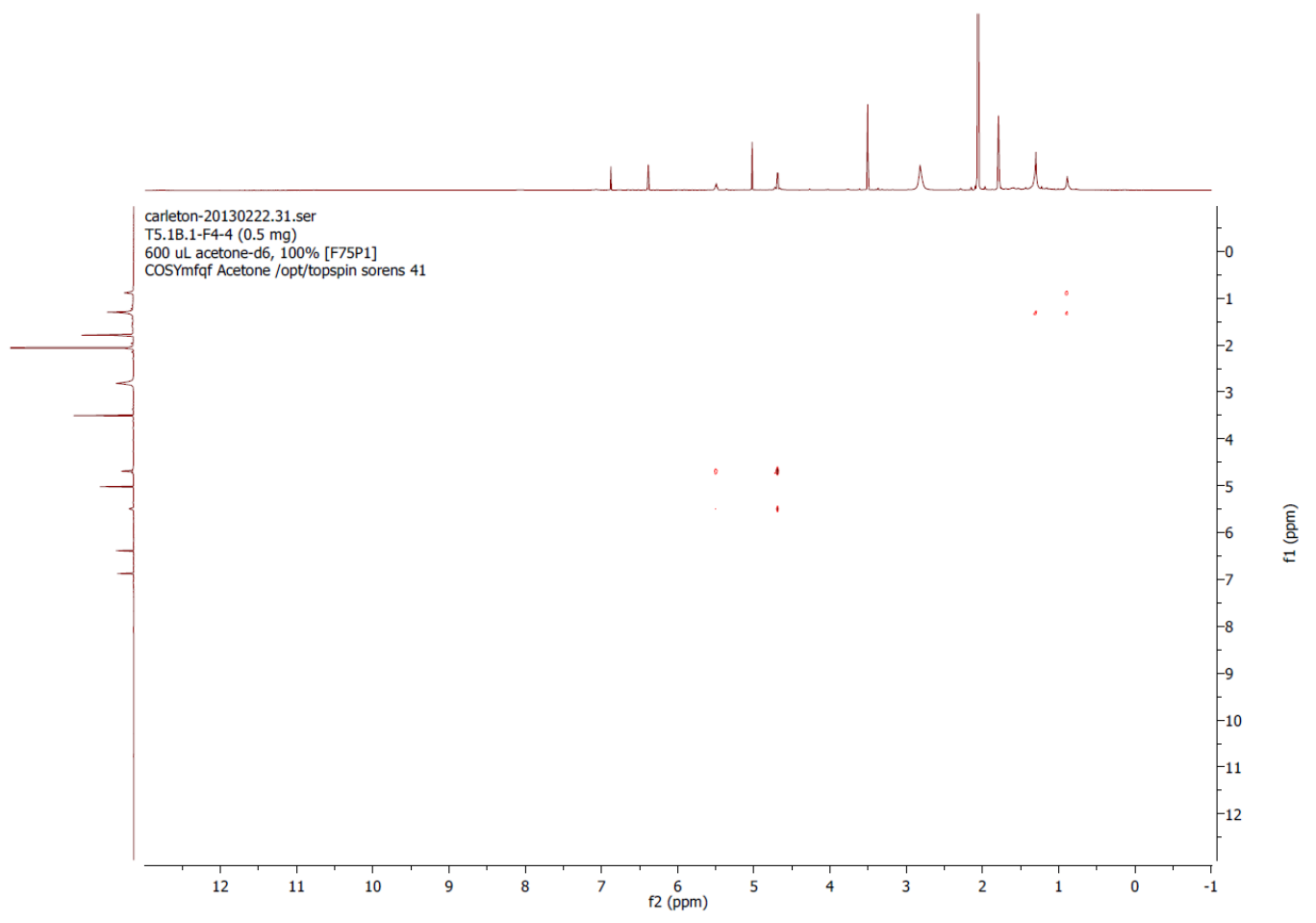


COMPOUND 3 ([(ethyl 3,6-dimethyl-4-prenyloxy)-2-O- $\beta$-D-glucopyranosyl)benzoate $)$

Mass spectrum of compound $\mathbf{3}$

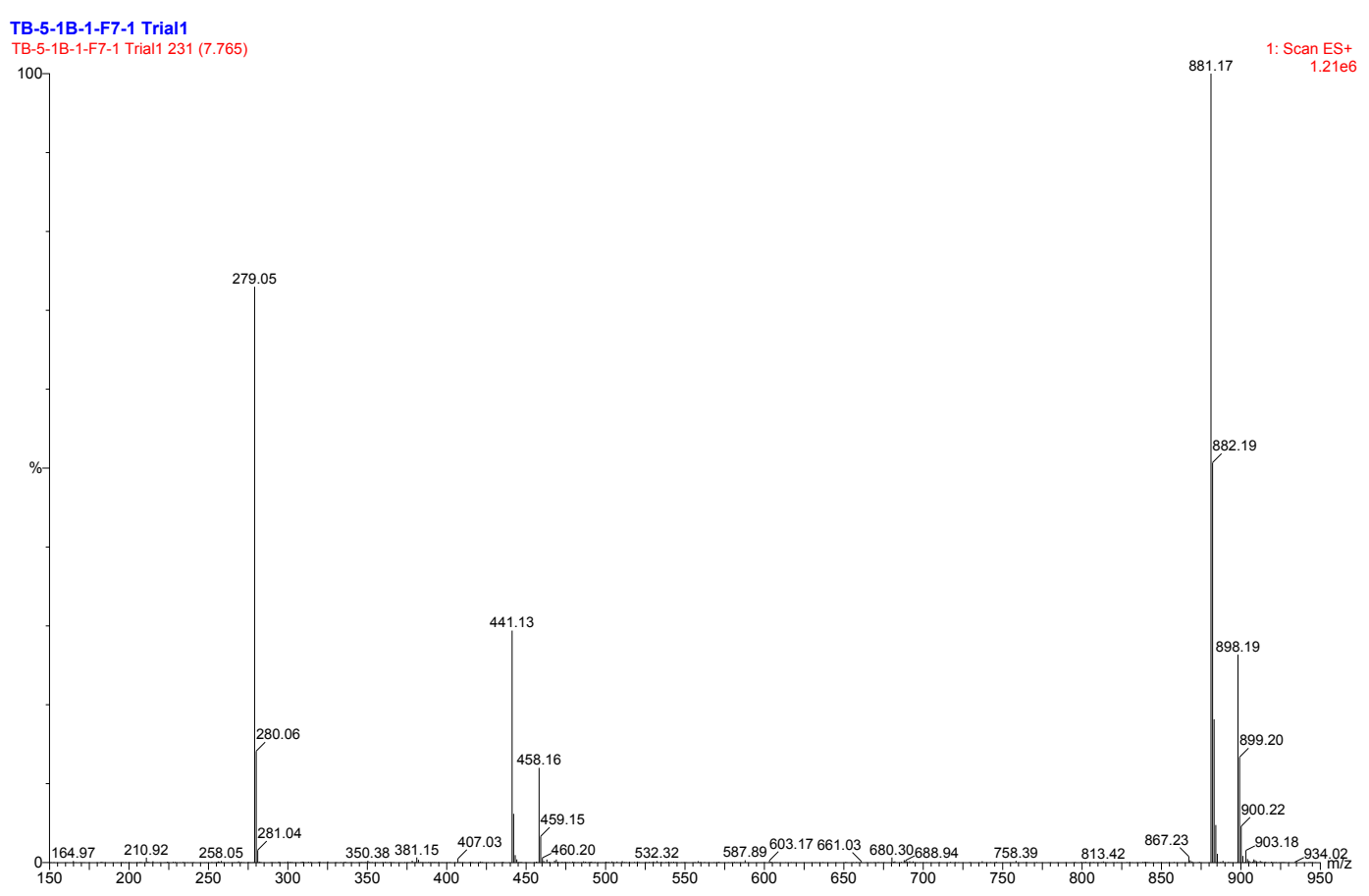

${ }^{1} \mathrm{H}$ NMR spectrum of compound $\mathbf{3}\left(\left(\mathrm{CH}_{3}\right)_{2} \mathrm{CO}, 700 \mathrm{MHz}\right)$.

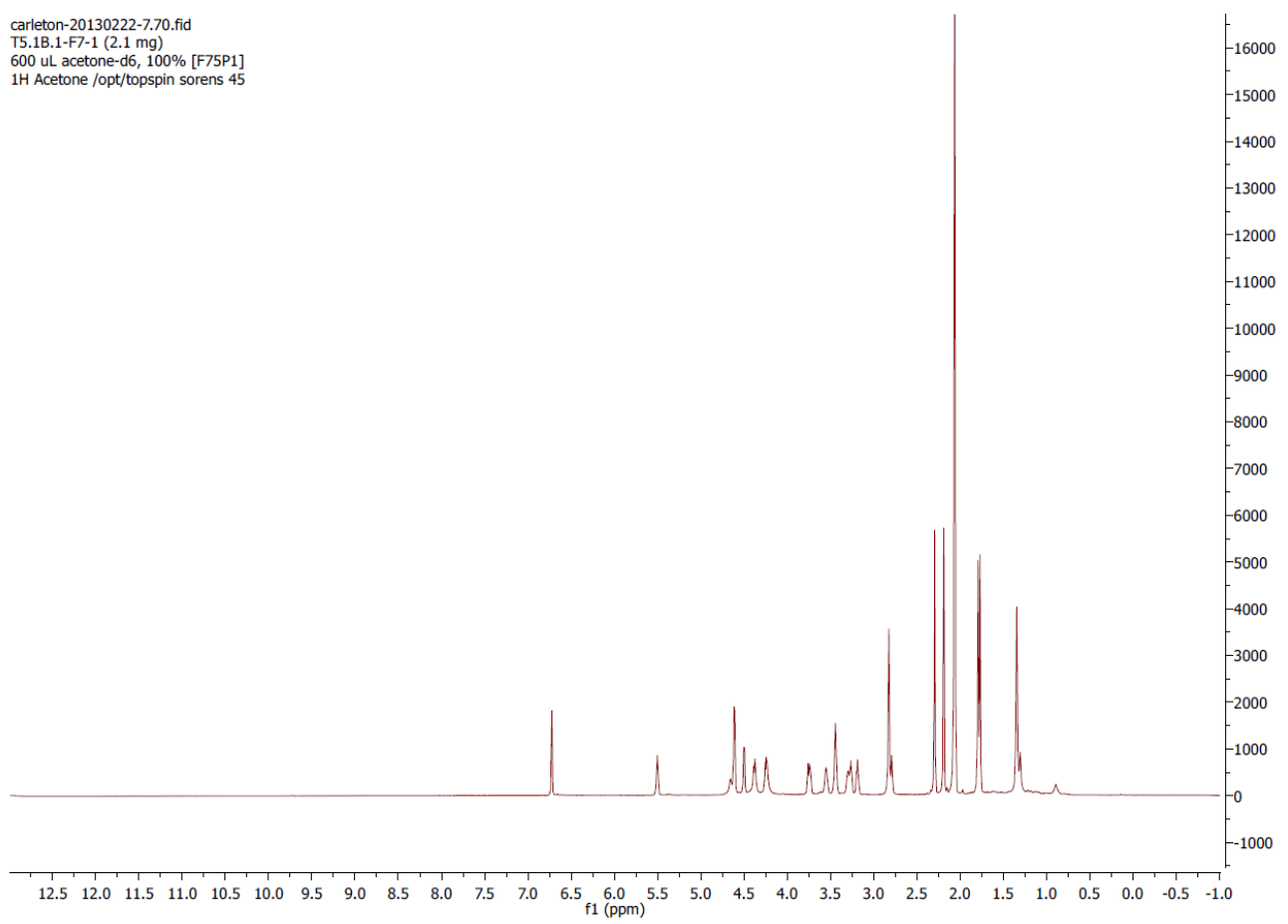


${ }^{13} \mathrm{C}$ NMR data for $3\left(\left(\mathrm{CH}_{3}\right)_{2} \mathrm{CO}, 176 \mathrm{MHz}\right)$.

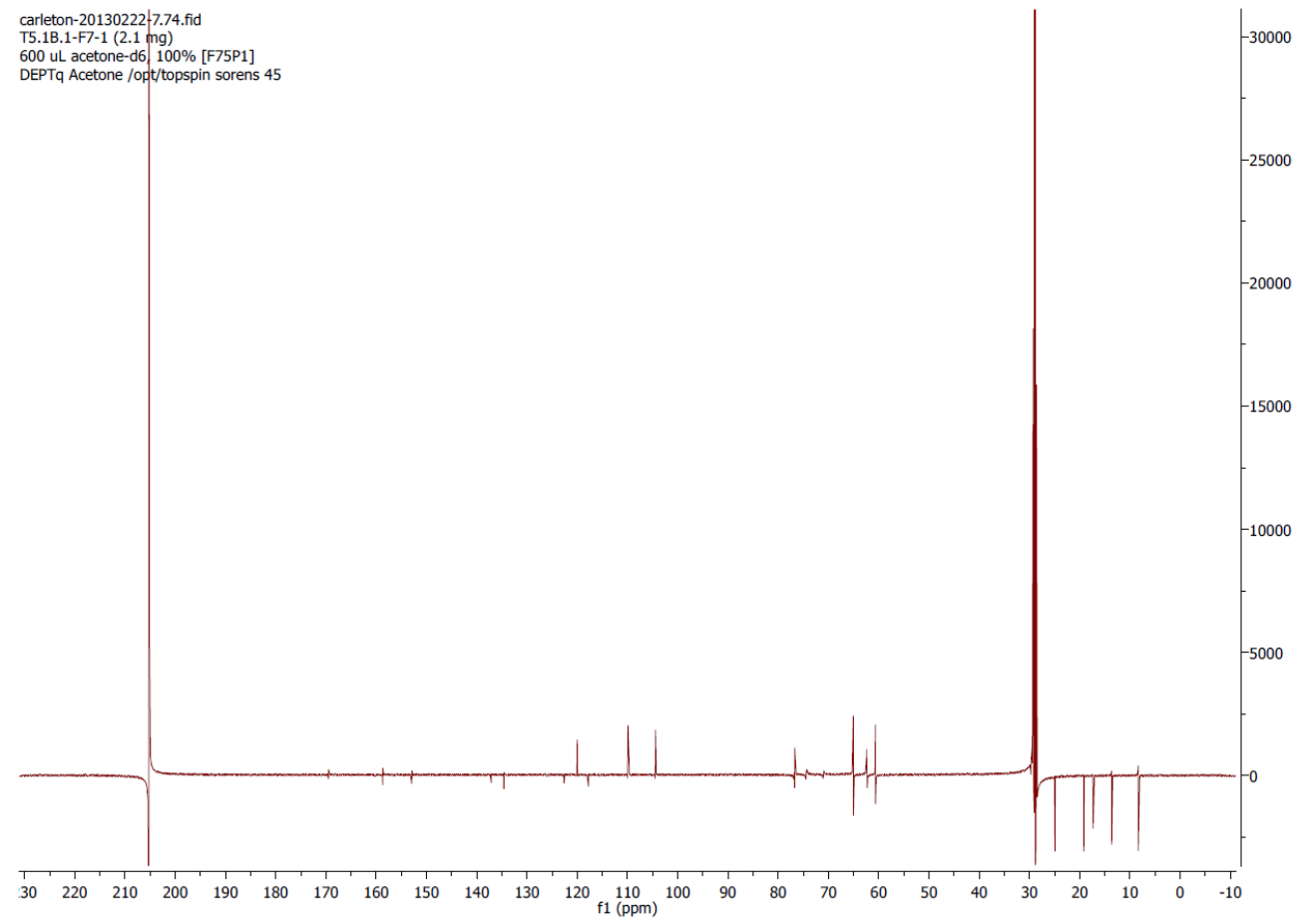

HSQC of compound $3\left(\left(\mathrm{CH}_{3}\right)_{2} \mathrm{CO}, 700 \mathrm{MHz}\right)$

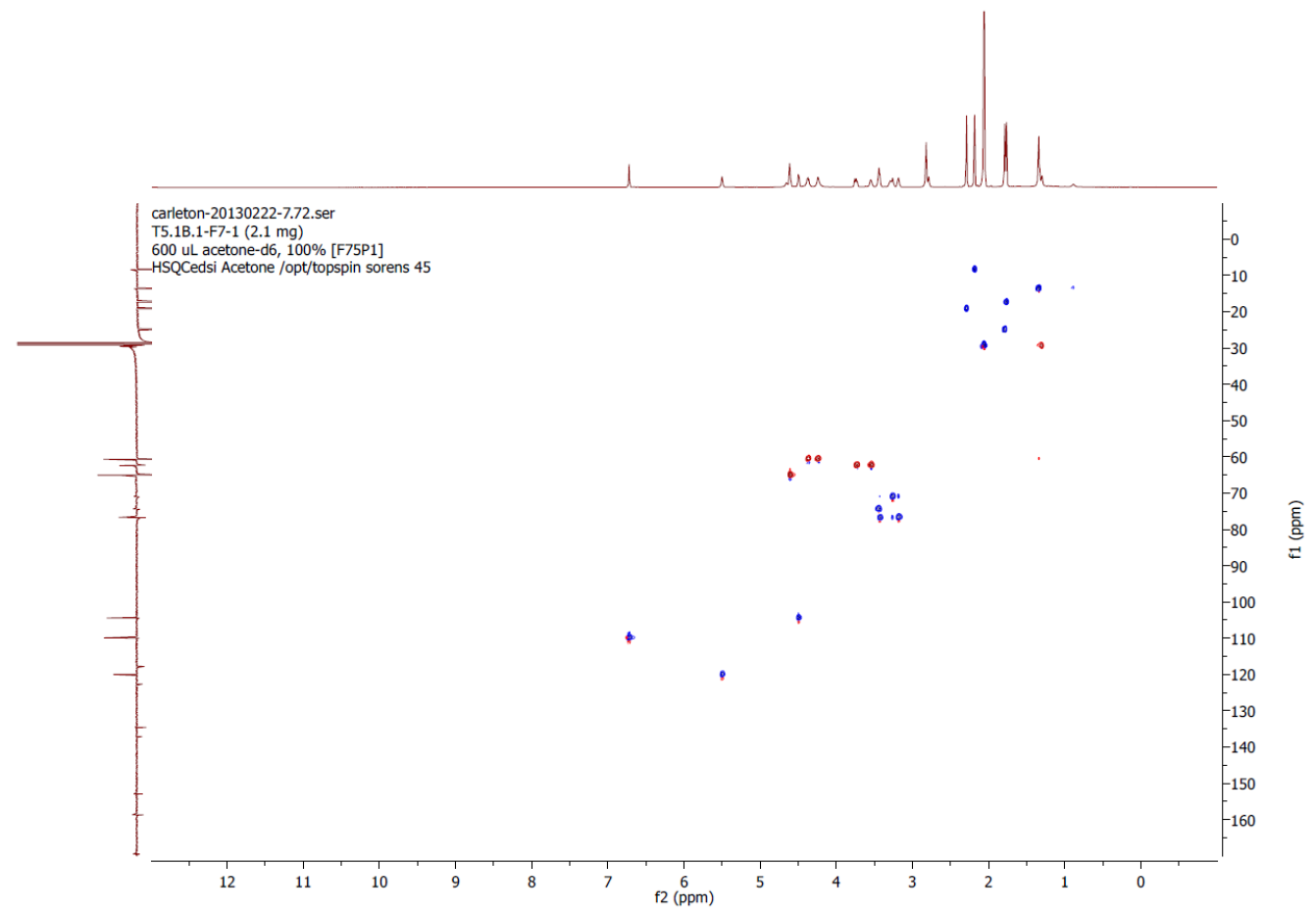


HMBC of compound $3\left(\left(\mathrm{CH}_{3}\right)_{2} \mathrm{CO}, 700 \mathrm{MHz}\right)$

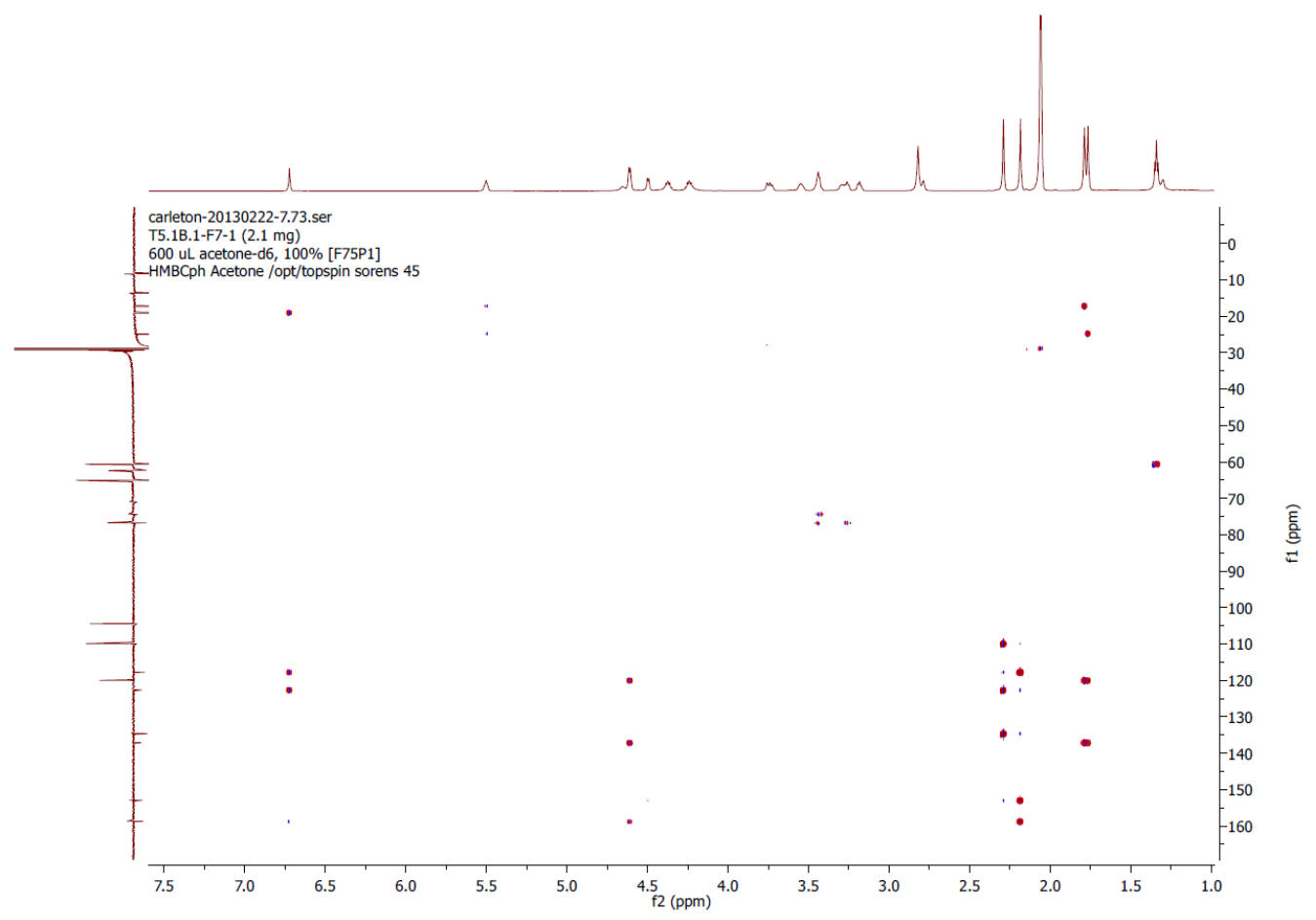

COSY of compound $3\left(\left(\mathrm{CH}_{3}\right)_{2} \mathrm{CO}, 700 \mathrm{MHz}\right)$

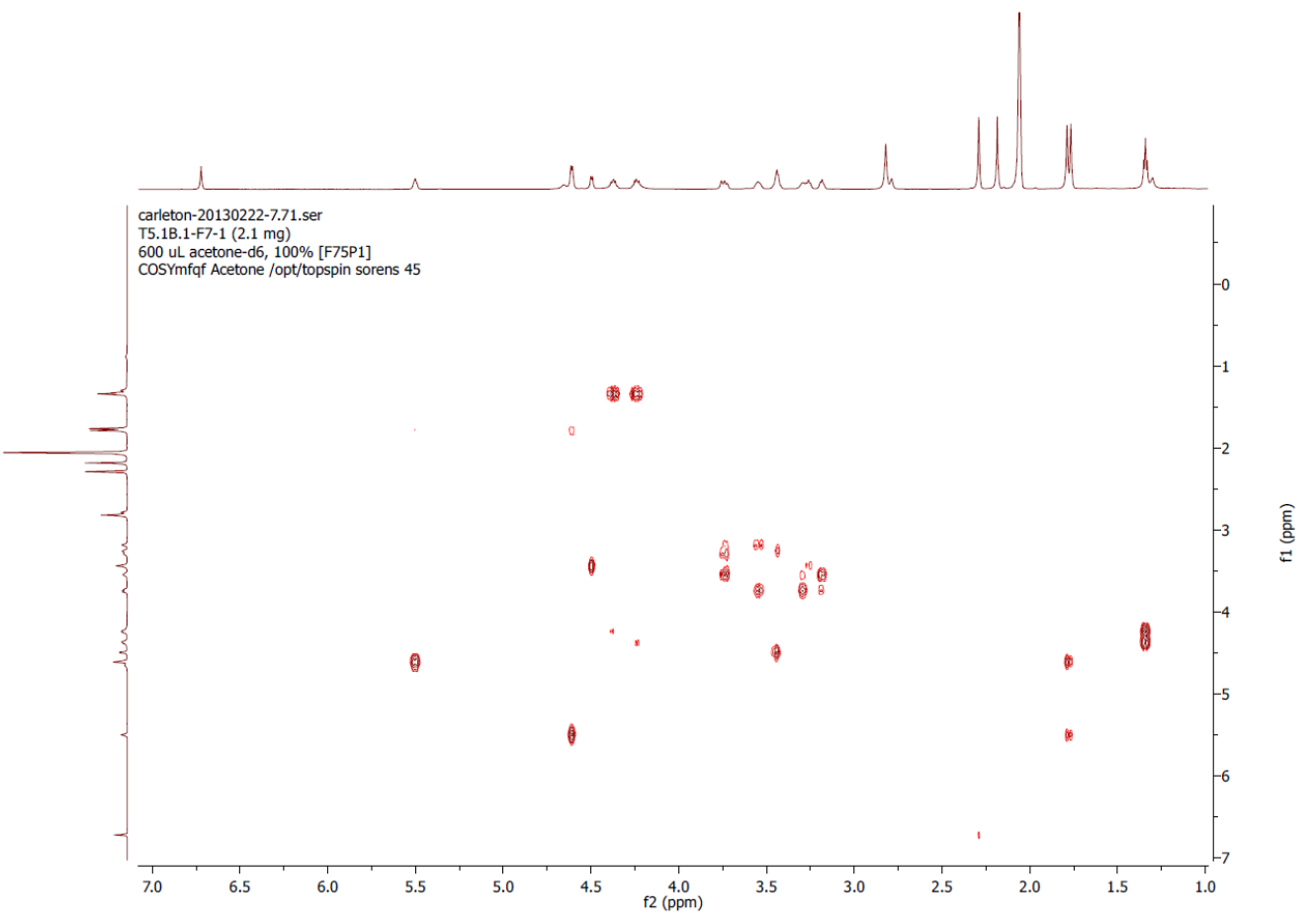




\section{COMPOUND 4 (5,5'-[oxybis(methylene)]bis-furfuryl alcohol)}

Mass spectrum of compound 4

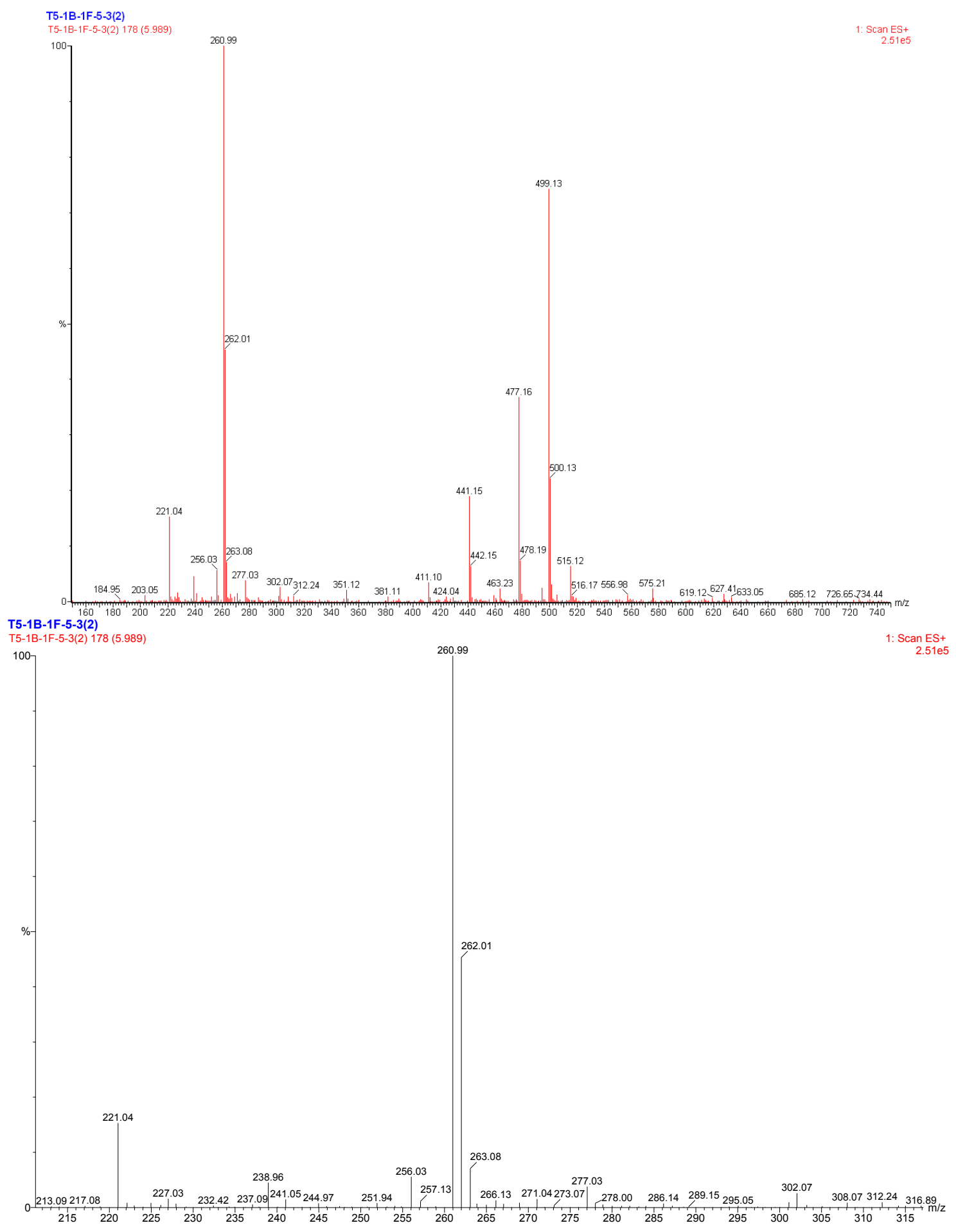


${ }^{1} \mathrm{H}$ NMR spectrum of compound $4\left(\left(\mathrm{CH}_{3}\right)_{2} \mathrm{CO}, 700 \mathrm{MHz}\right)$

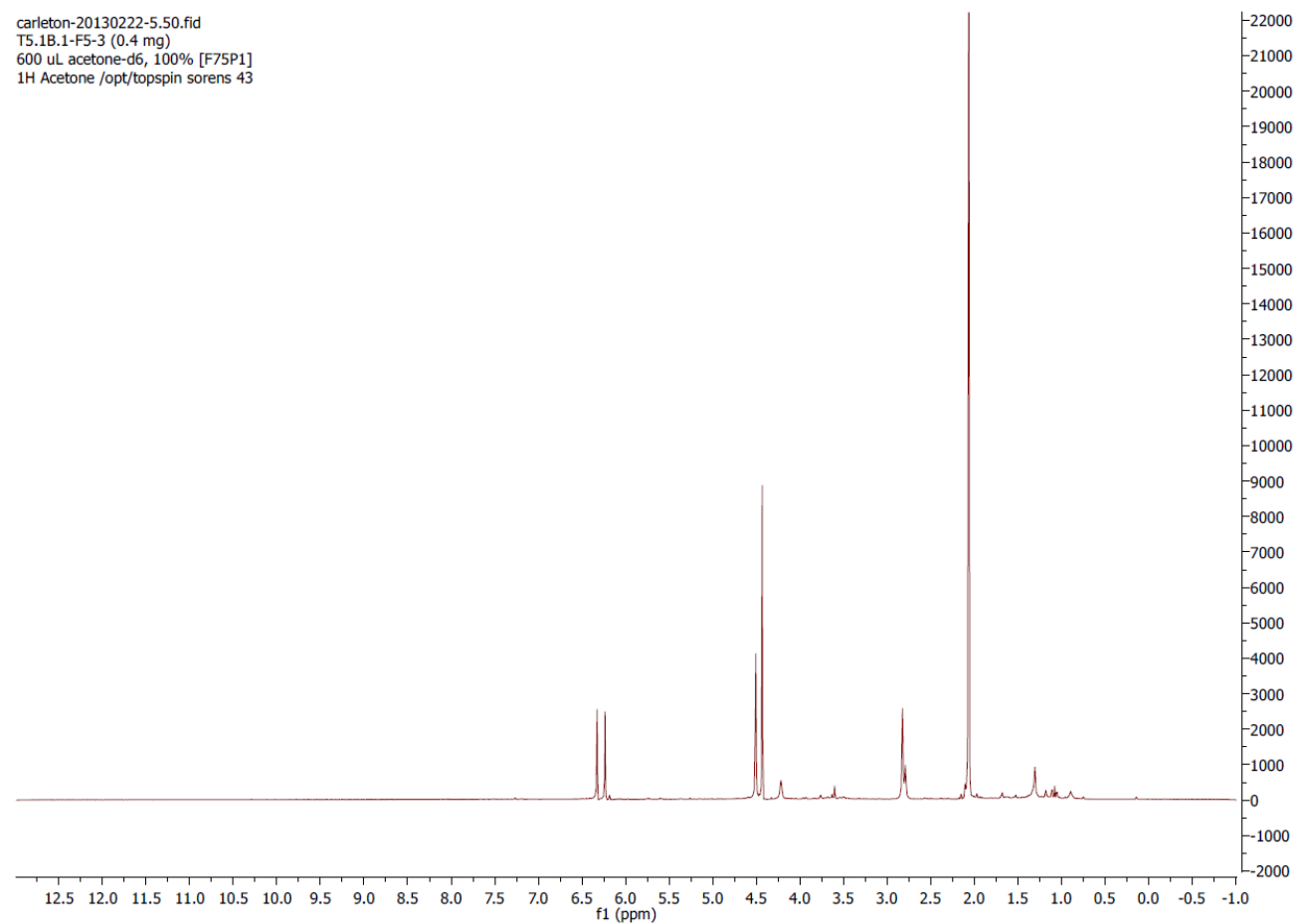

${ }^{13} \mathrm{C}$ NMR spectrum of compound $4\left(\left(\mathrm{CH}_{3}\right)_{2} \mathrm{CO}, 176 \mathrm{MHz}\right)$

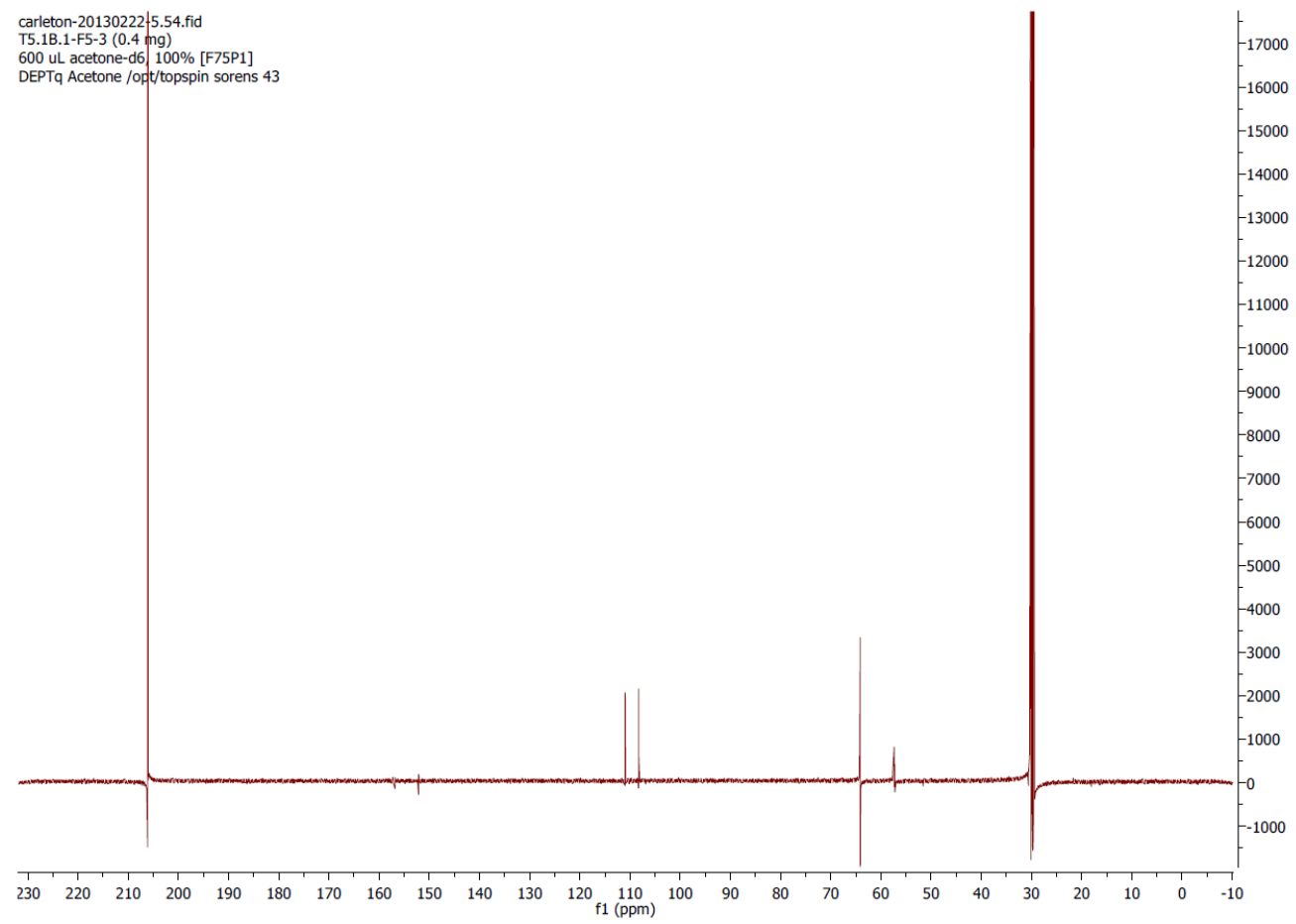


HSQC of compound $4\left(\left(\mathrm{CH}_{3}\right)_{2} \mathrm{CO}, 700 \mathrm{MHz}\right)$

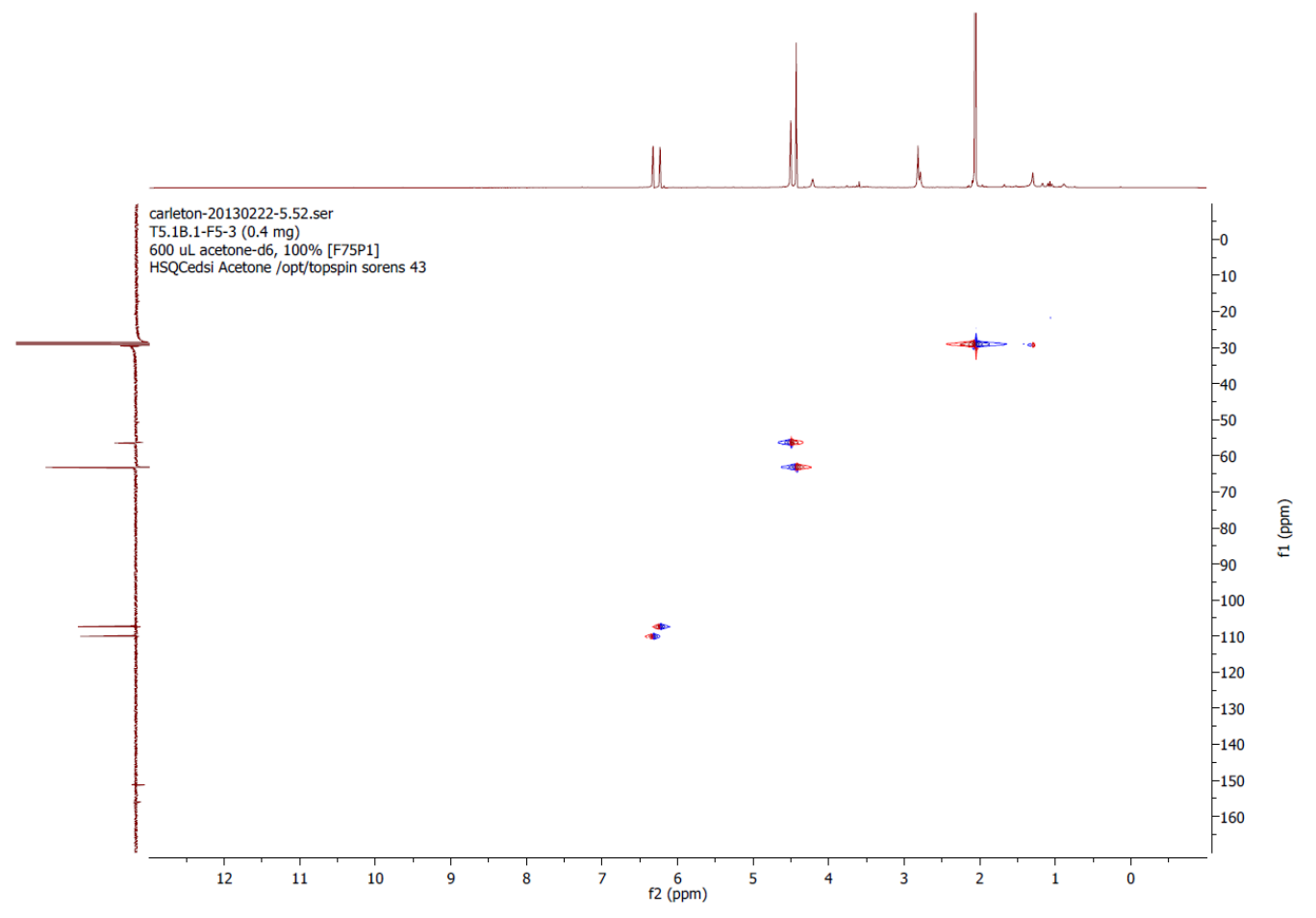

HMBC of compound $4\left(\left(\mathrm{CH}_{3}\right)_{2} \mathrm{CO}, 700 \mathrm{MHz}\right)$

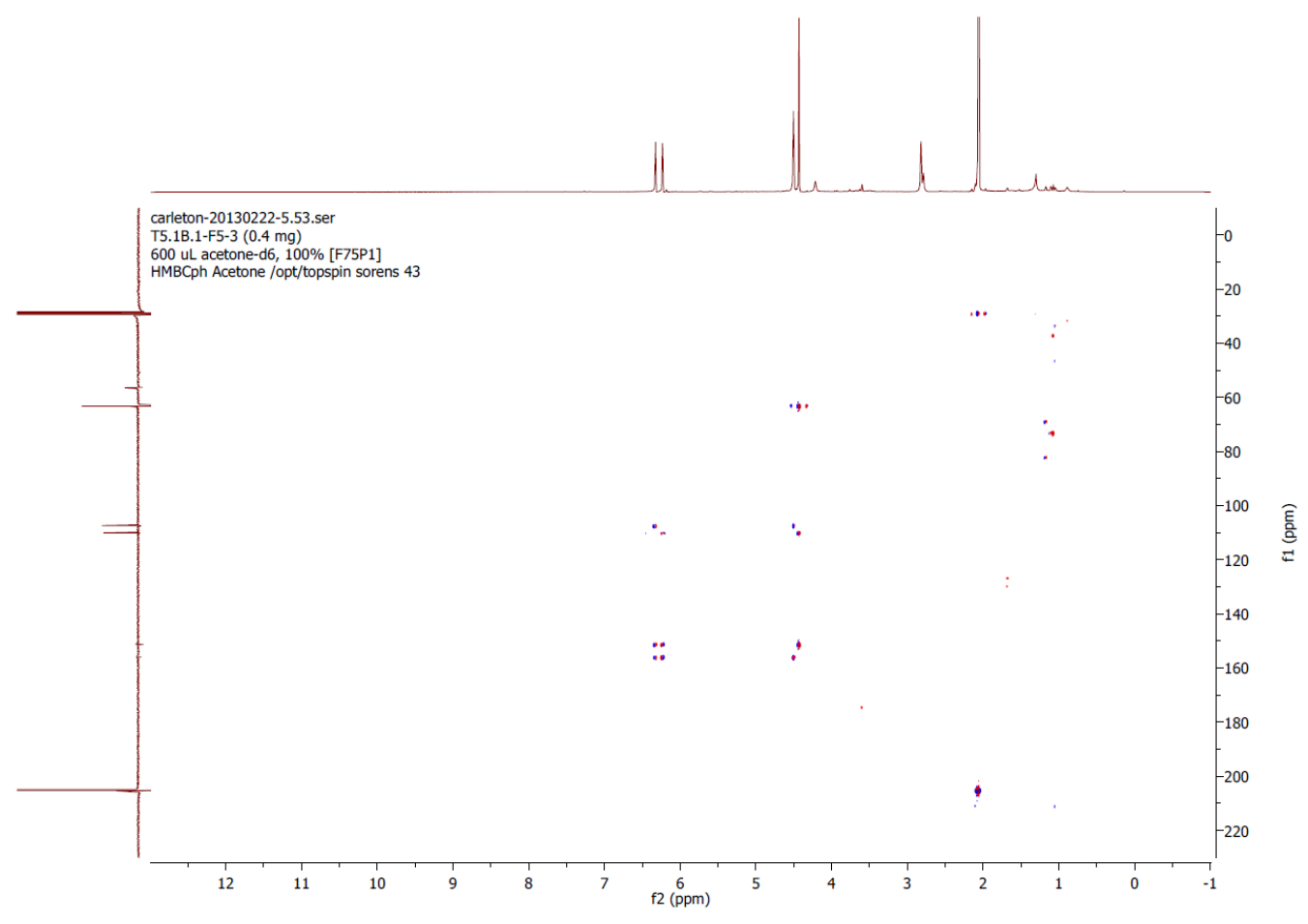


COSY of compound $4\left(\left(\mathrm{CH}_{3}\right)_{2} \mathrm{CO}, 700 \mathrm{MHz}\right)$

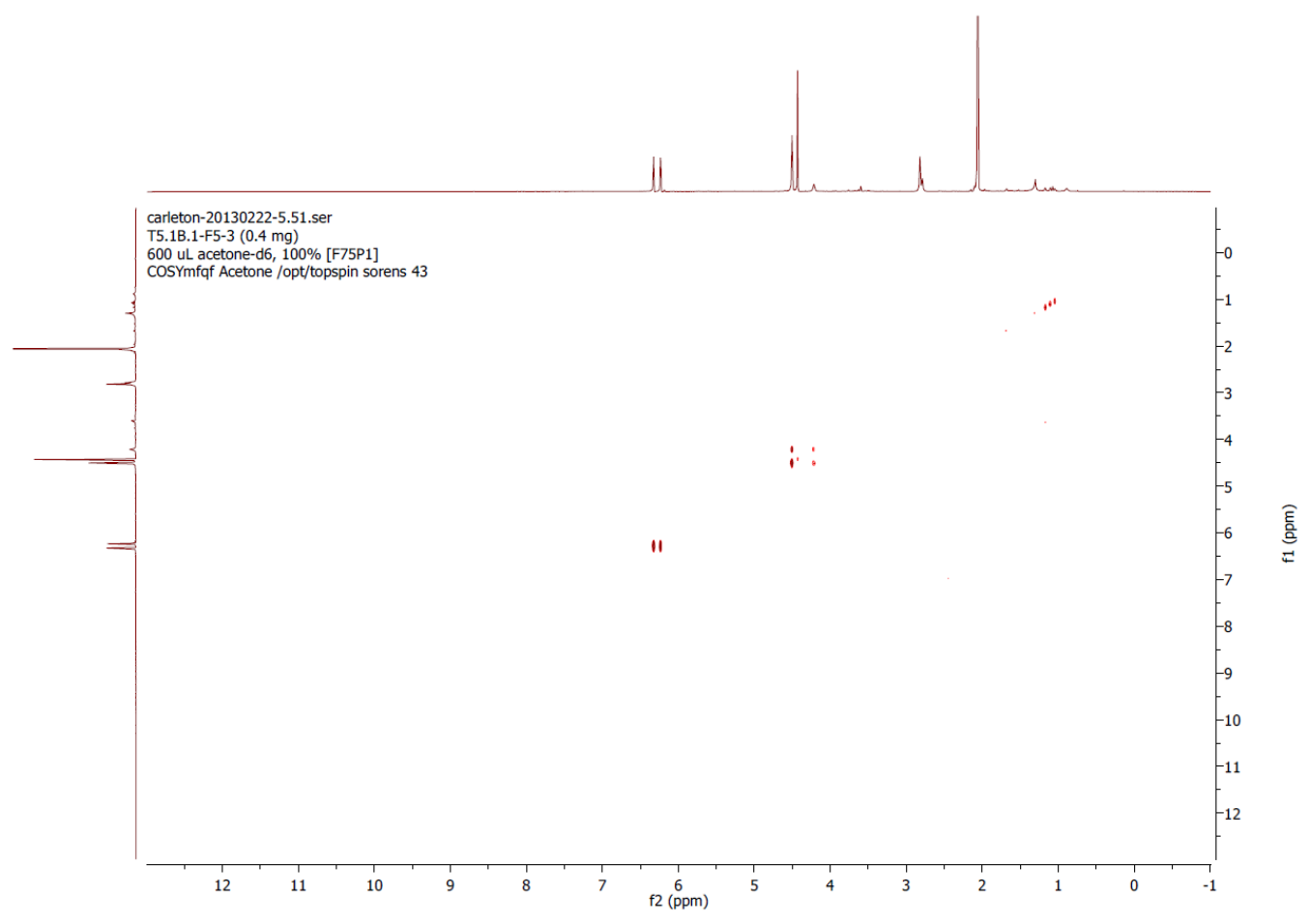


COMPOUND $5(R)$-2-methyl-2,3-dihydrobenzofuran-4-carboxylic acid)

Mass spectrum of compound $\mathbf{5}$

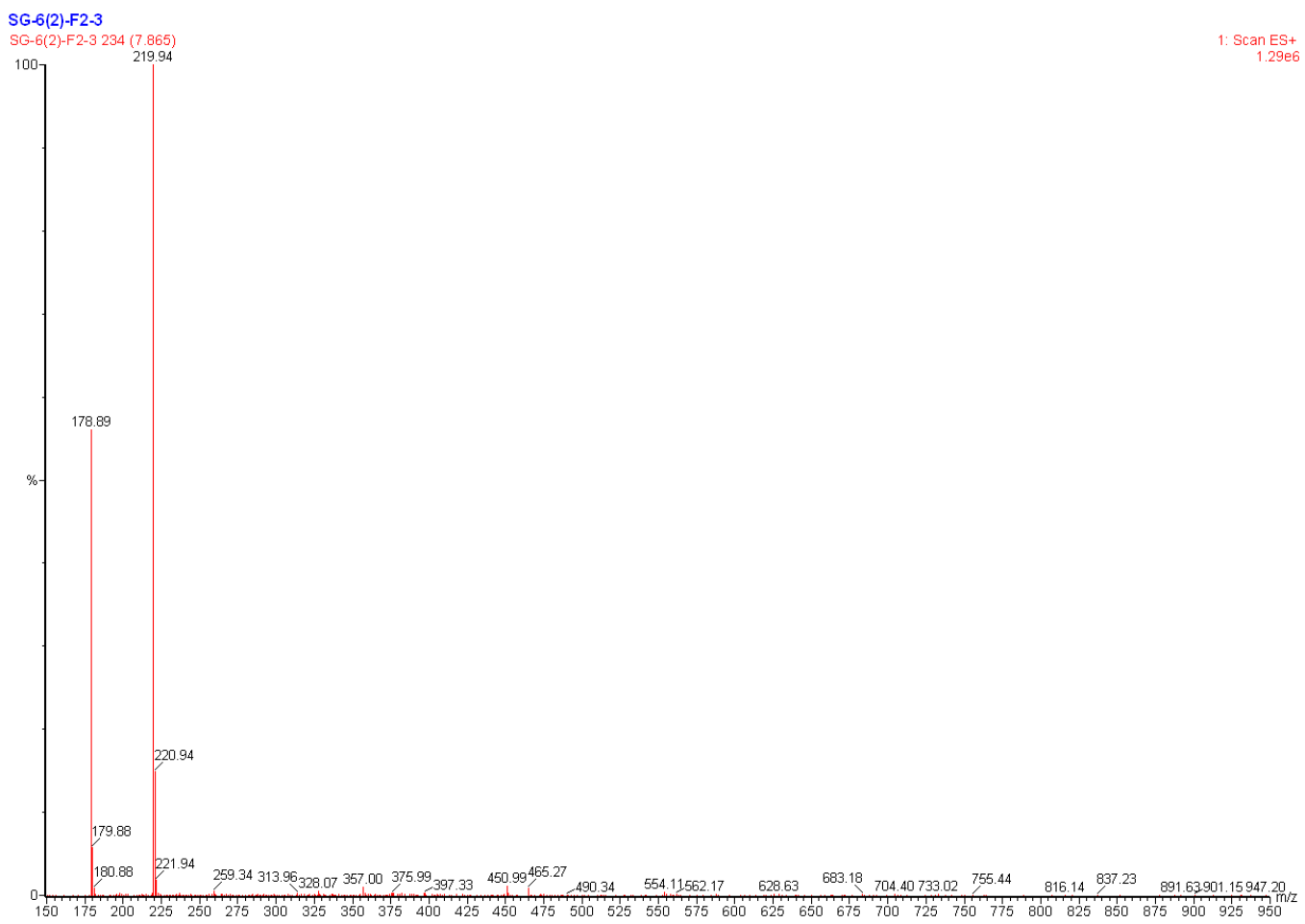

${ }^{1} \mathrm{H}$ NMR spectrum of compound $5\left(\left(\mathrm{CDCl}_{3}\right), 400 \mathrm{MHz}\right)$

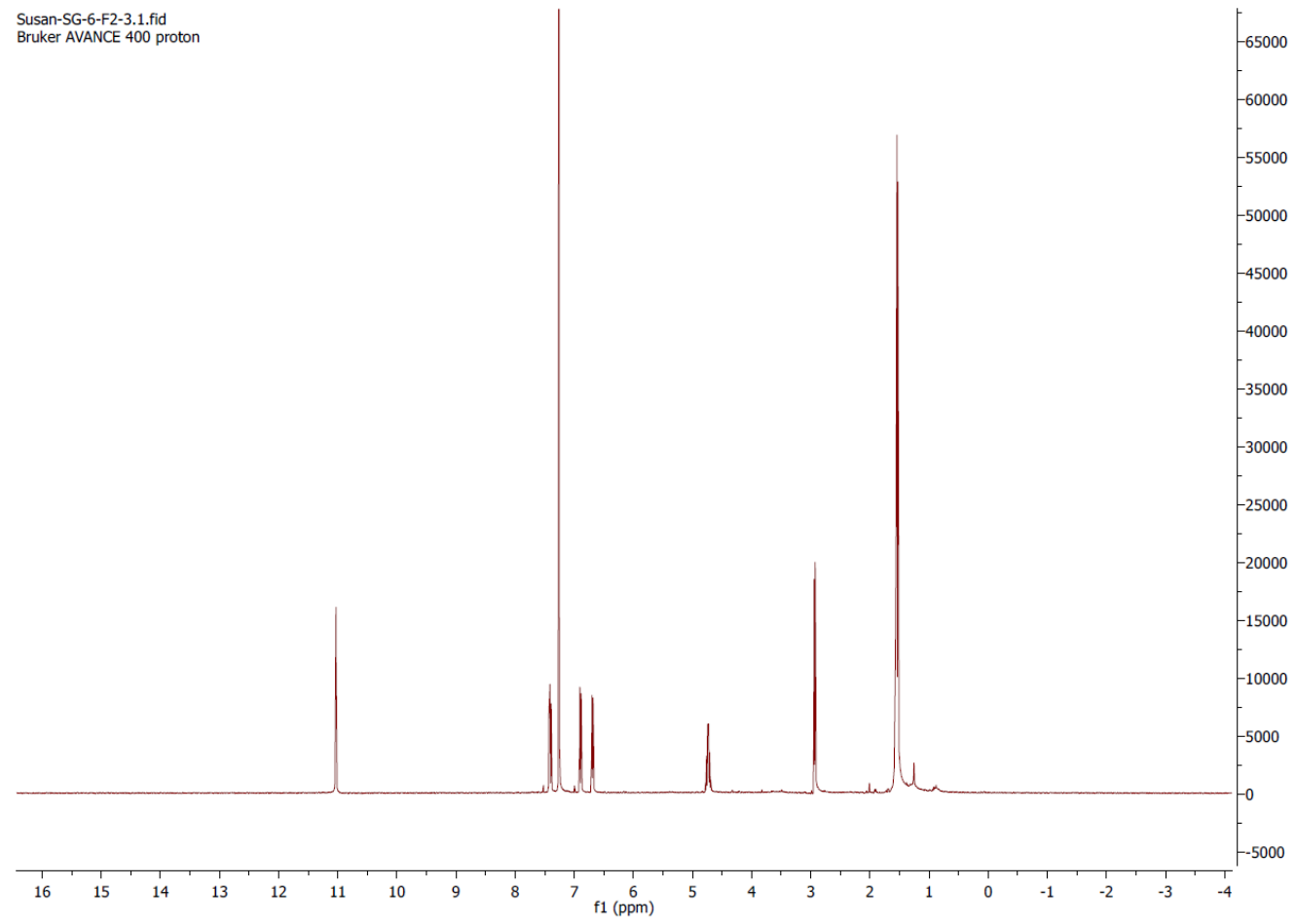


${ }^{13} \mathrm{C}$ NMR spectrum of compound $\mathbf{5}\left(\left(\mathrm{CDCl}_{3}\right), 100 \mathrm{MHz}\right)$

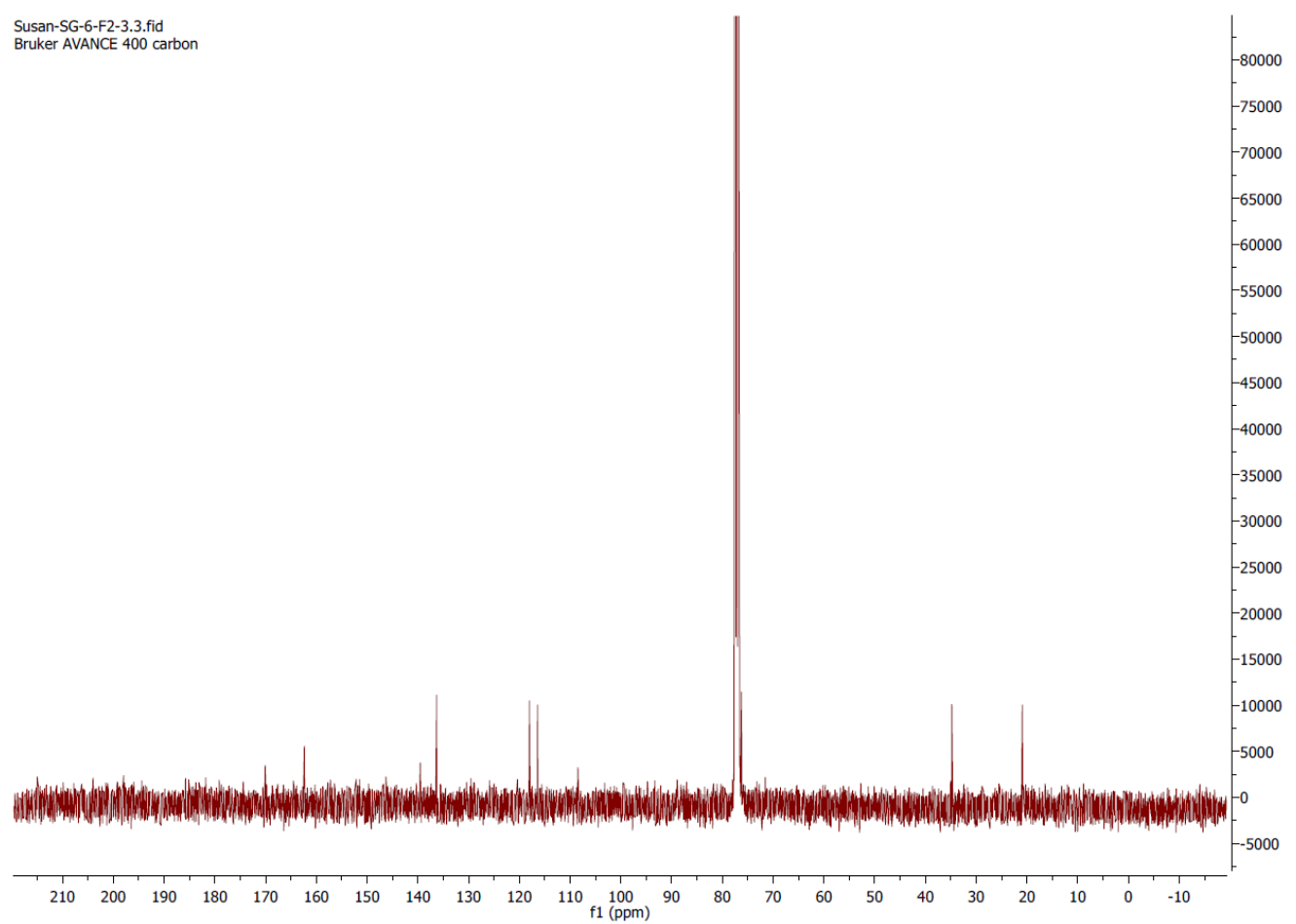

HSQC of compound $5\left(\mathrm{CDCl}_{3}, 400 \mathrm{MHz}\right)$

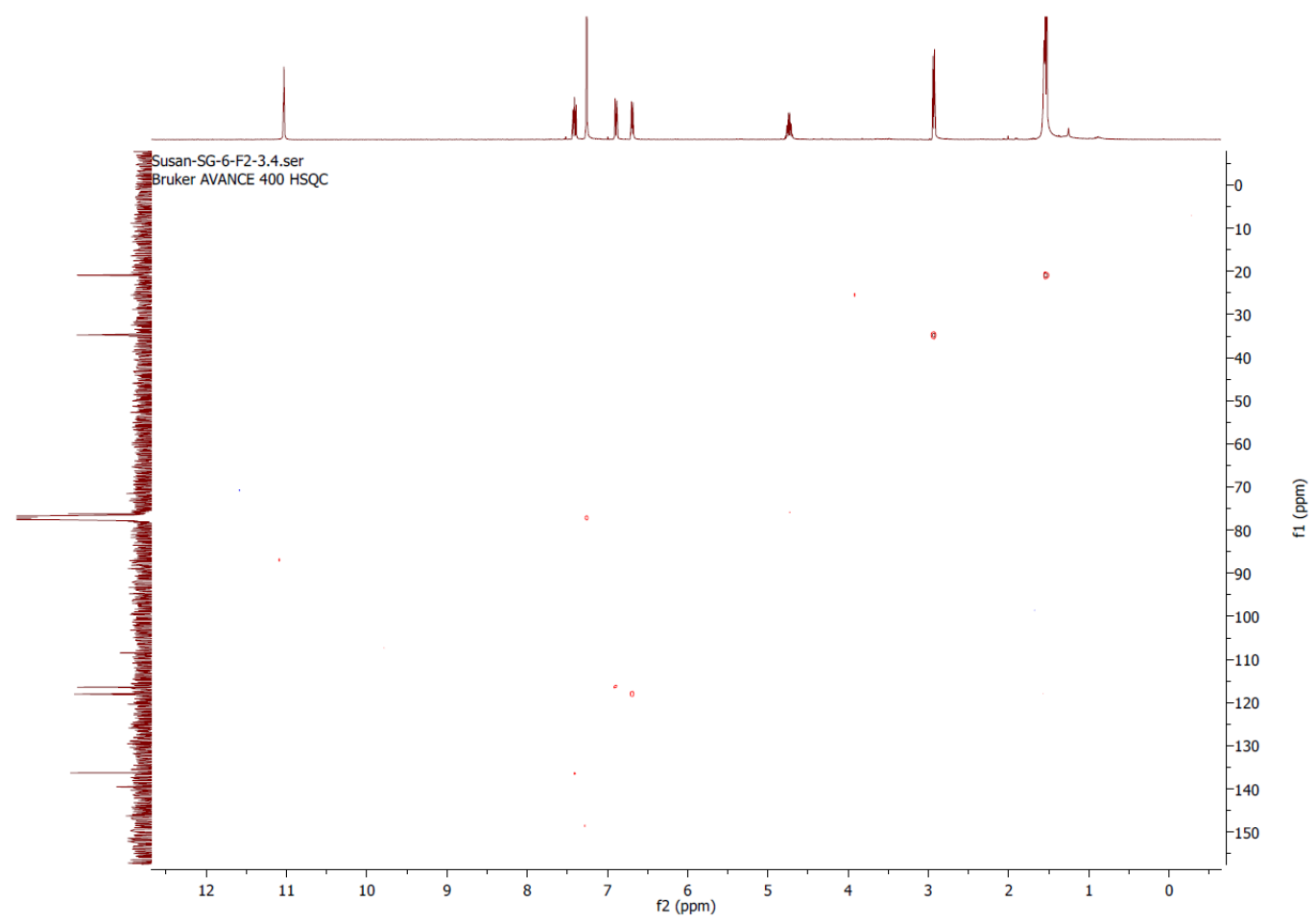


$\mathrm{HMBC}$ of compound $5\left(\mathrm{CDCl}_{3}, 400 \mathrm{MHz}\right)$

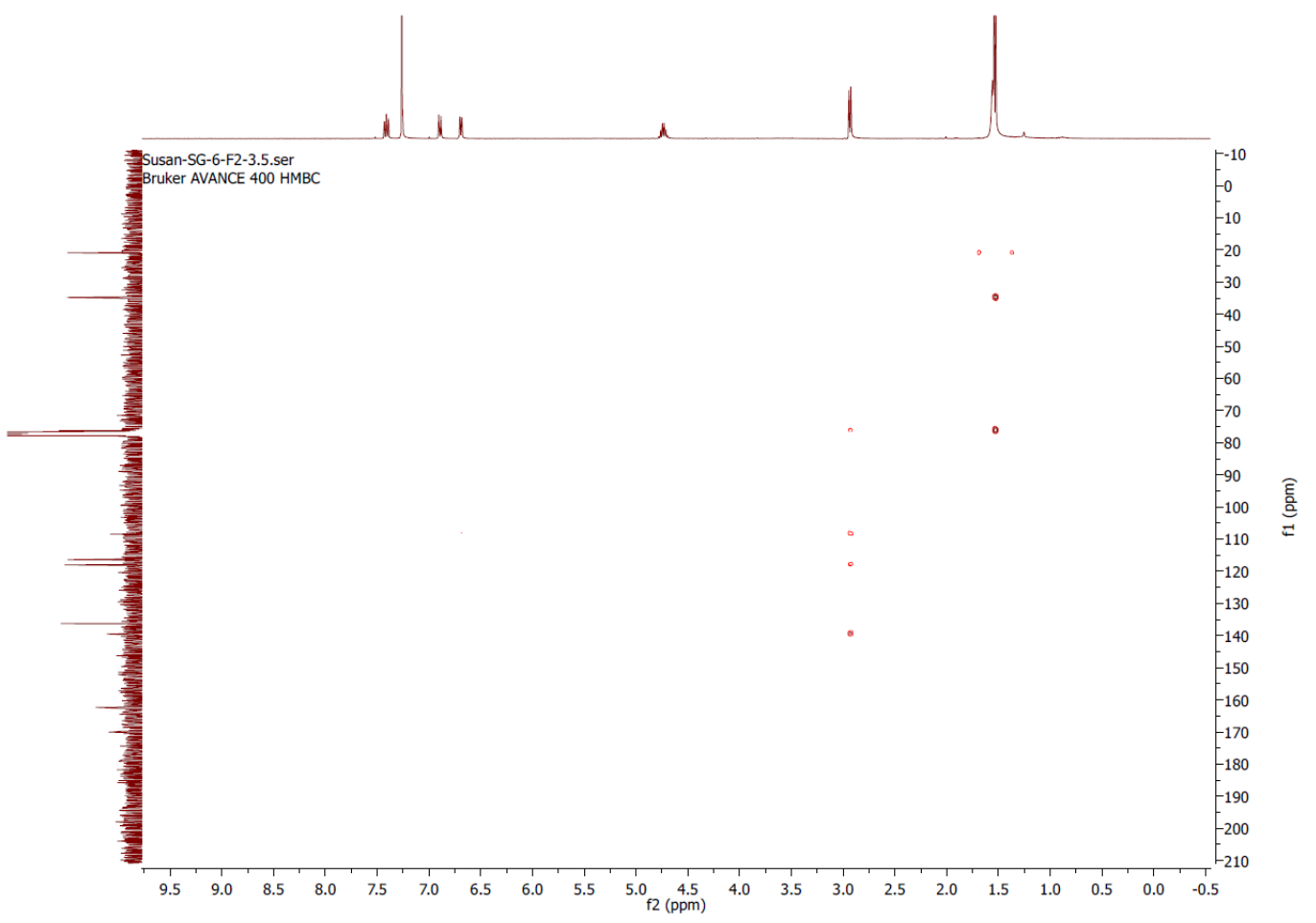

COSY of compound $5\left(\mathrm{CDCl}_{3}, 400 \mathrm{MHz}\right)$

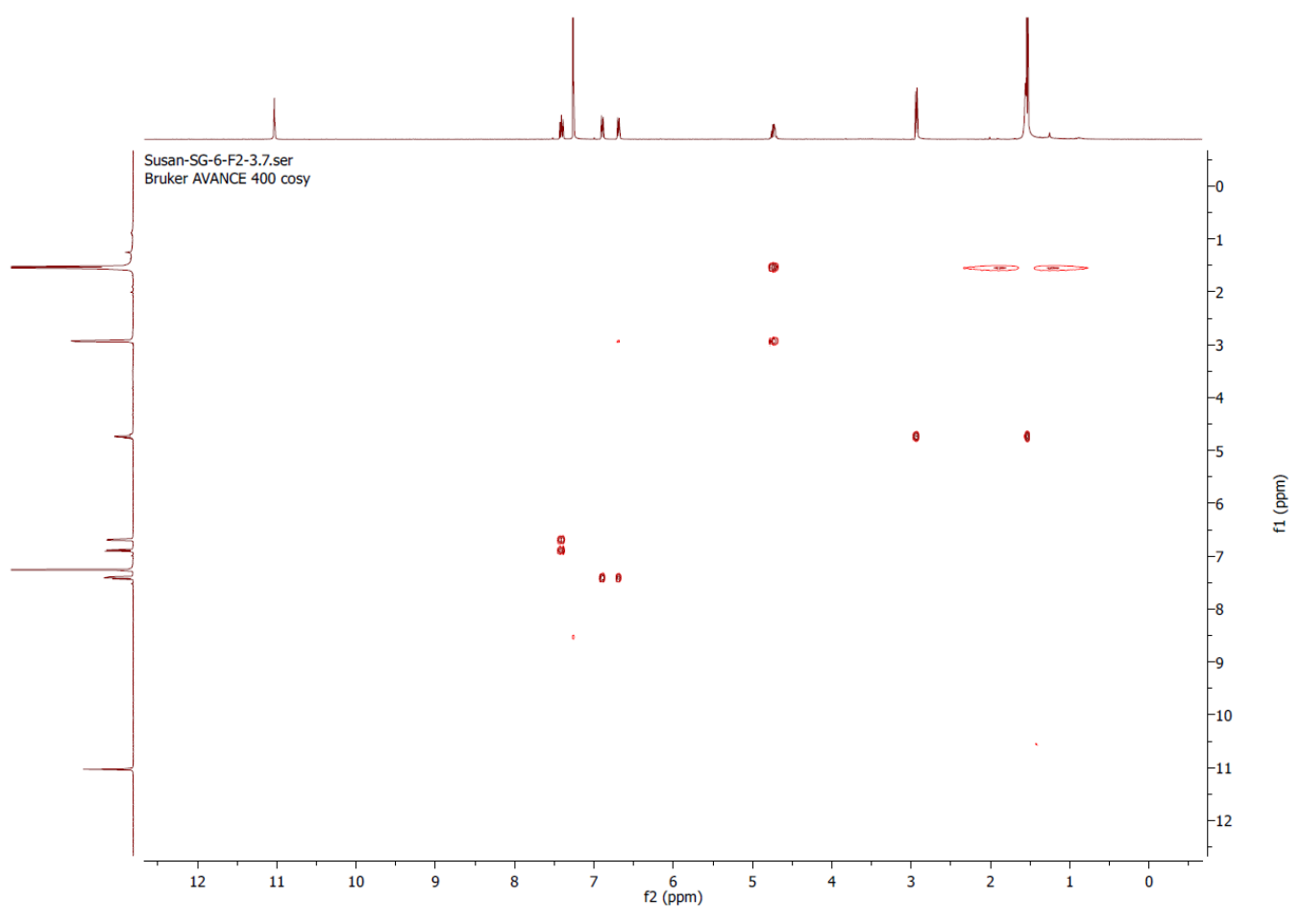


DEPT-135 of compound $5\left(\mathrm{CDCl}_{3}, 100 \mathrm{MHz}\right)$

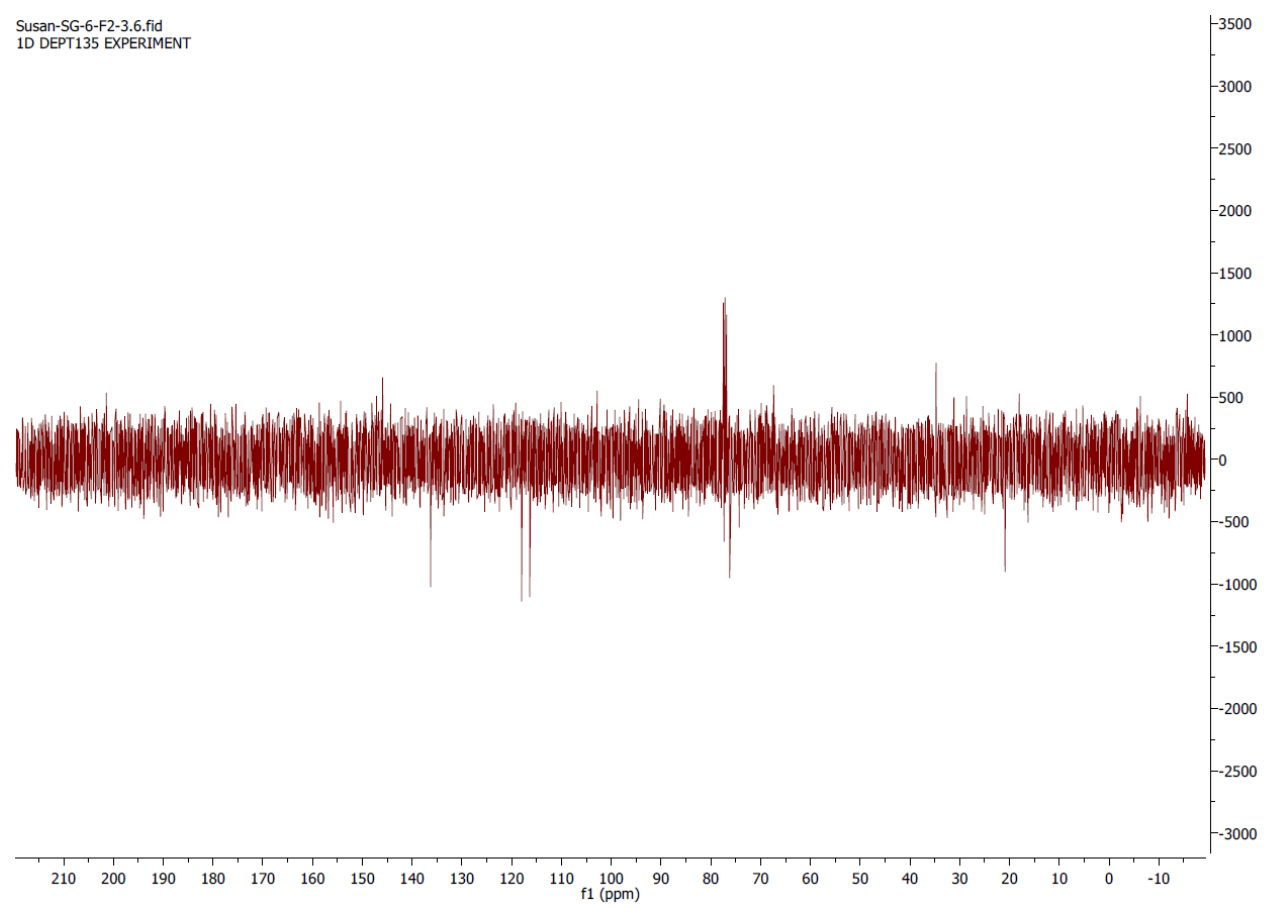

COMPOUND 6 ((R)-6-hydroxy-2-methyl-2,3-dihydrobenzofuran-4-carboxylic acid)

Mass spectrum of compound $\mathbf{6}$

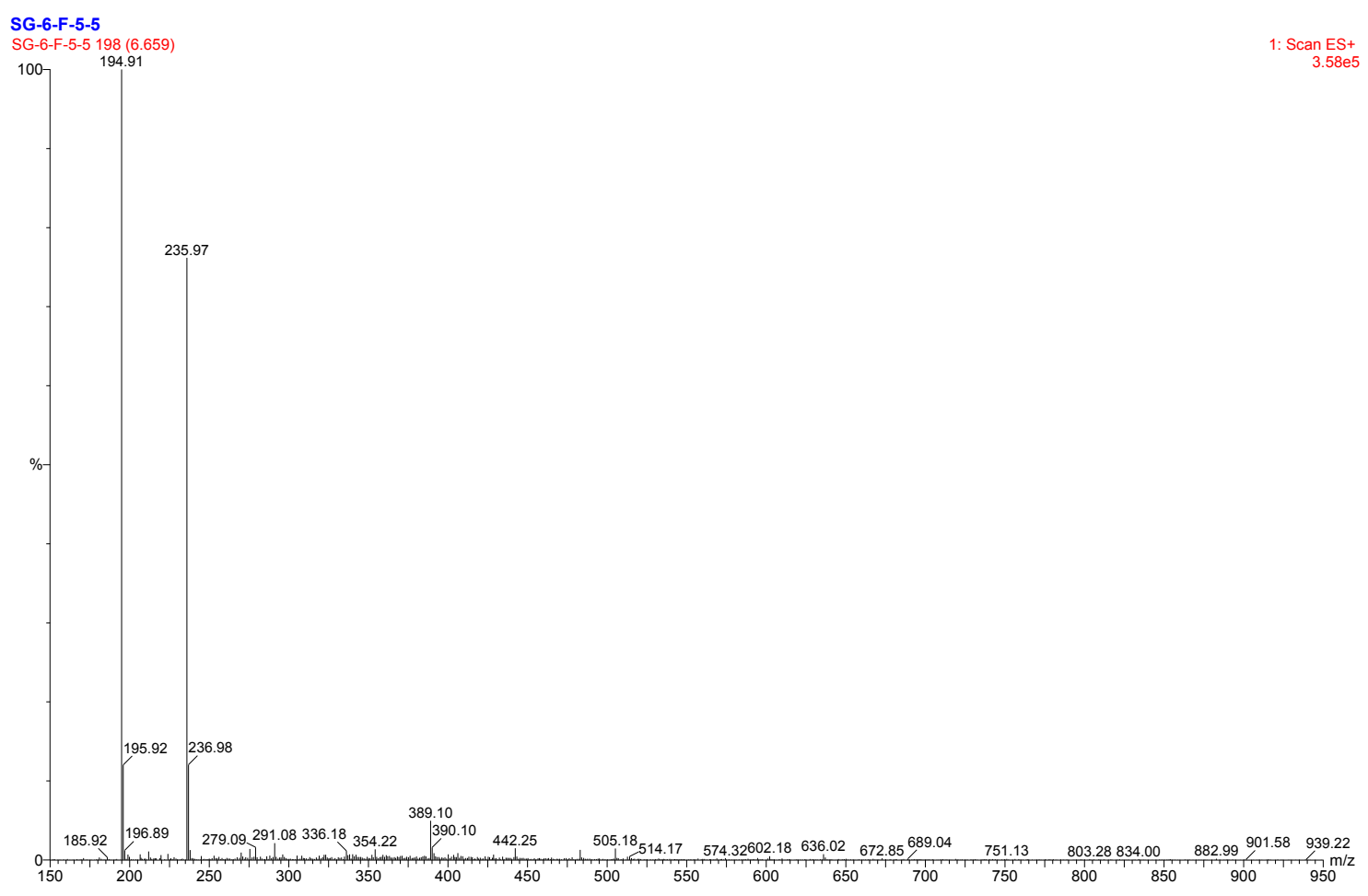


${ }^{1} \mathrm{H}$ NMR spectrum of compound 6 ((CD $\left.\left.\mathrm{CD}_{3} \mathrm{OD}\right), 400 \mathrm{MHz}\right)$

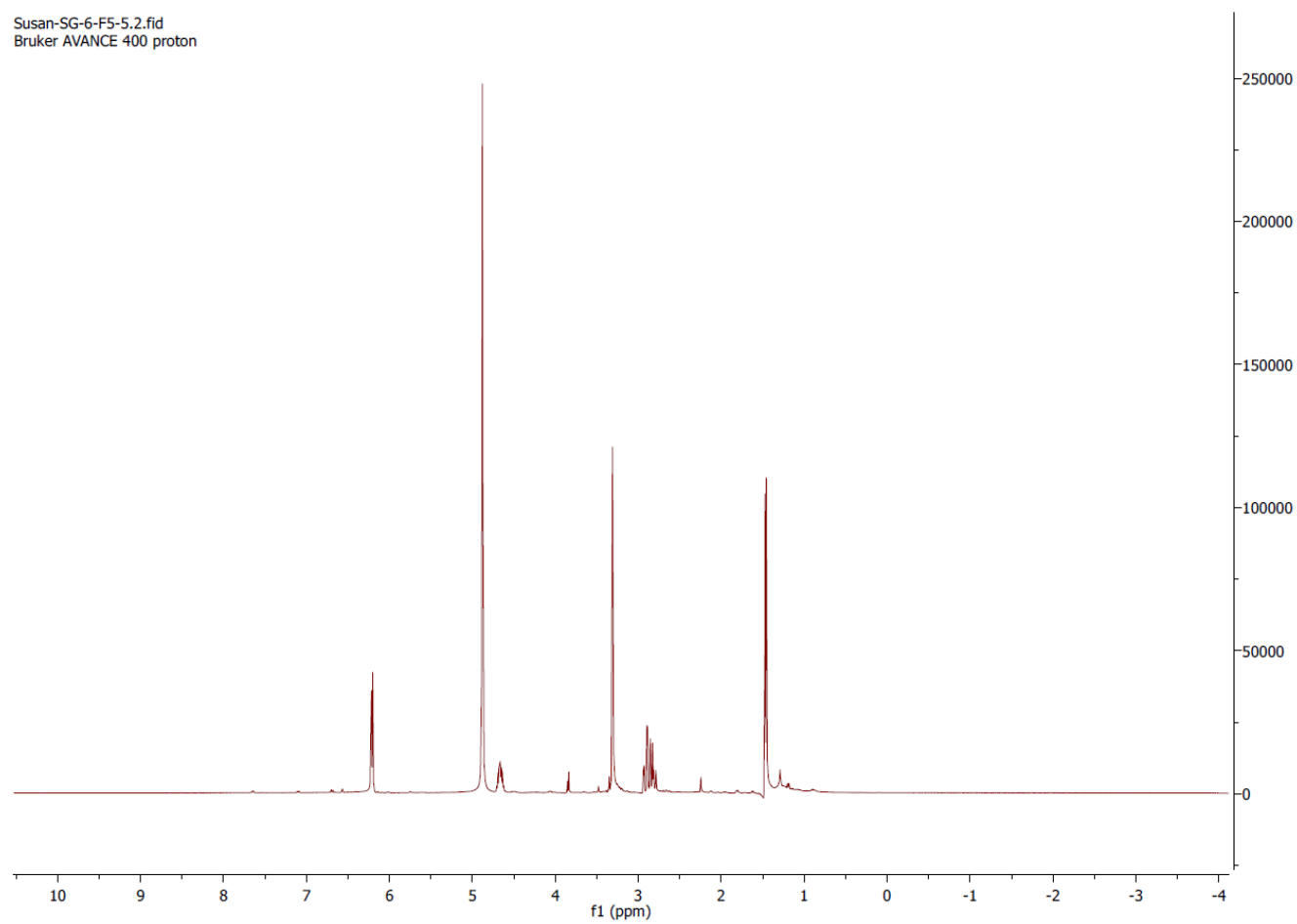

${ }^{13} \mathrm{C}$ NMR spectrum of compound $\mathbf{6}\left(\left(\mathrm{CD}_{3} \mathrm{OD}\right), 100 \mathrm{MHz}\right)$ Susan-SG-6-F5-5.3.jid
Bruker AVANCE 400 carbon

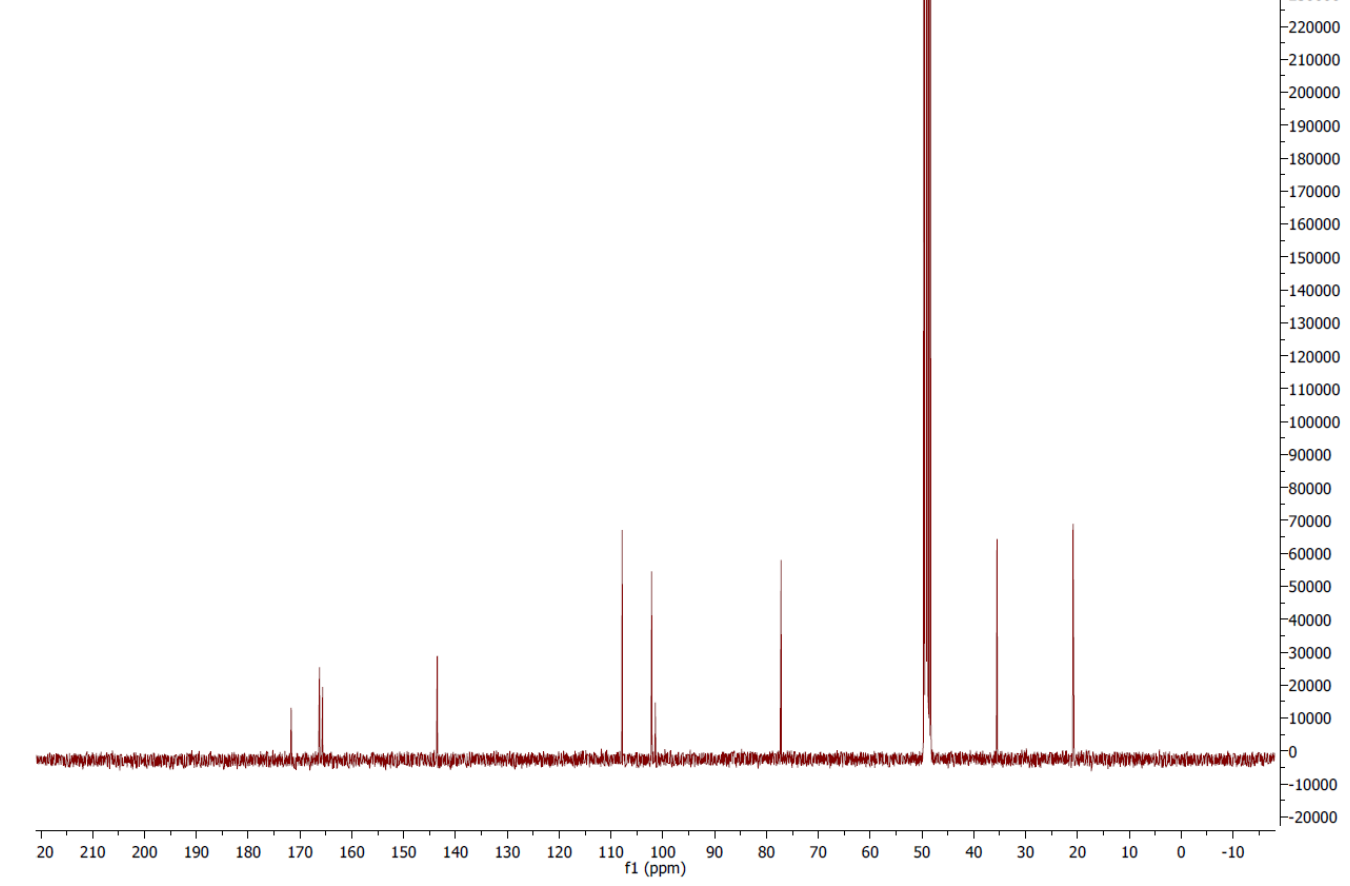


HSQC of compound $6\left(\mathrm{CD}_{3} \mathrm{OD}, 400 \mathrm{MHz}\right)$

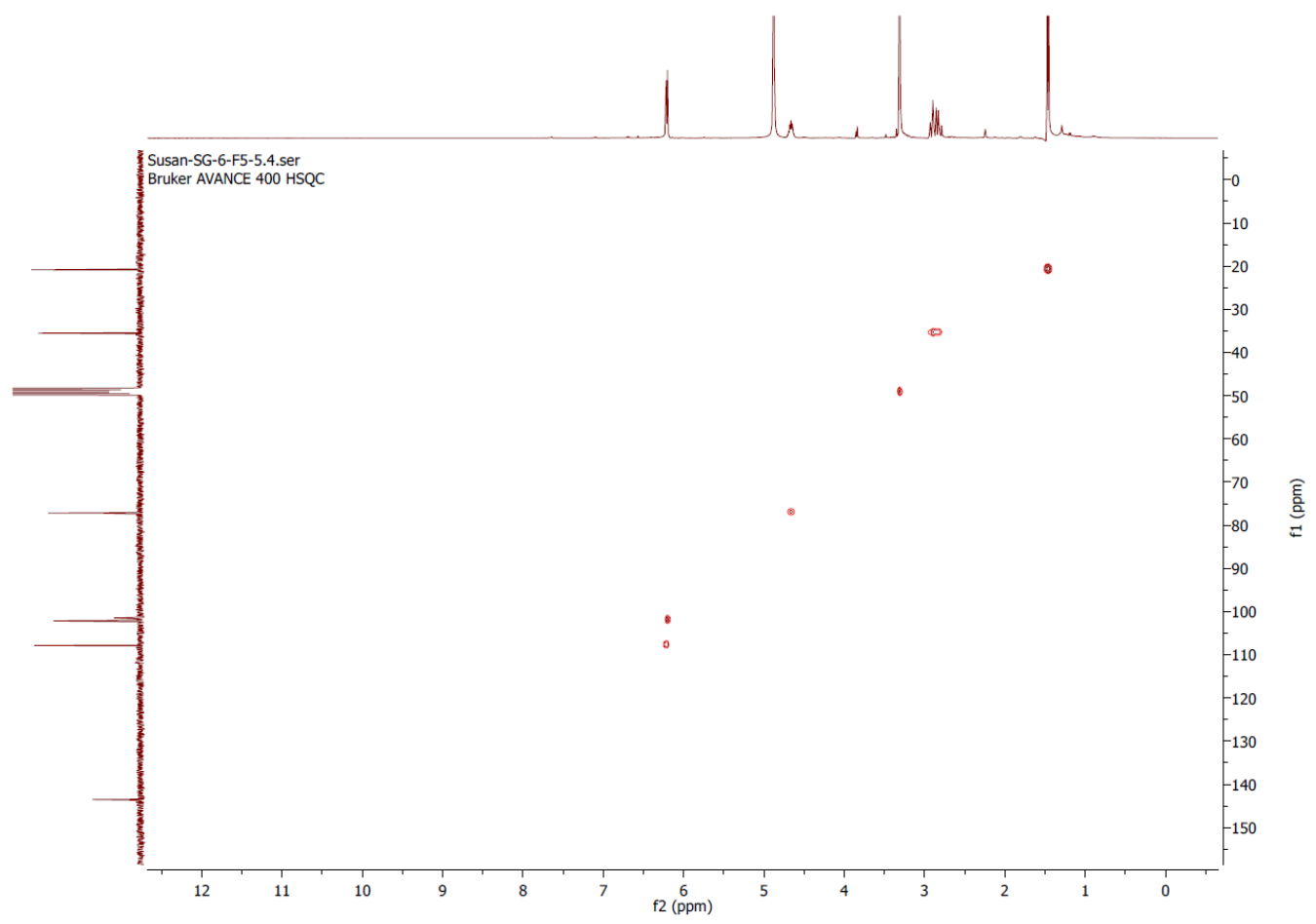

HMBC of compound $6\left(\mathrm{CD}_{3} \mathrm{OD}, 400 \mathrm{MHz}\right)$

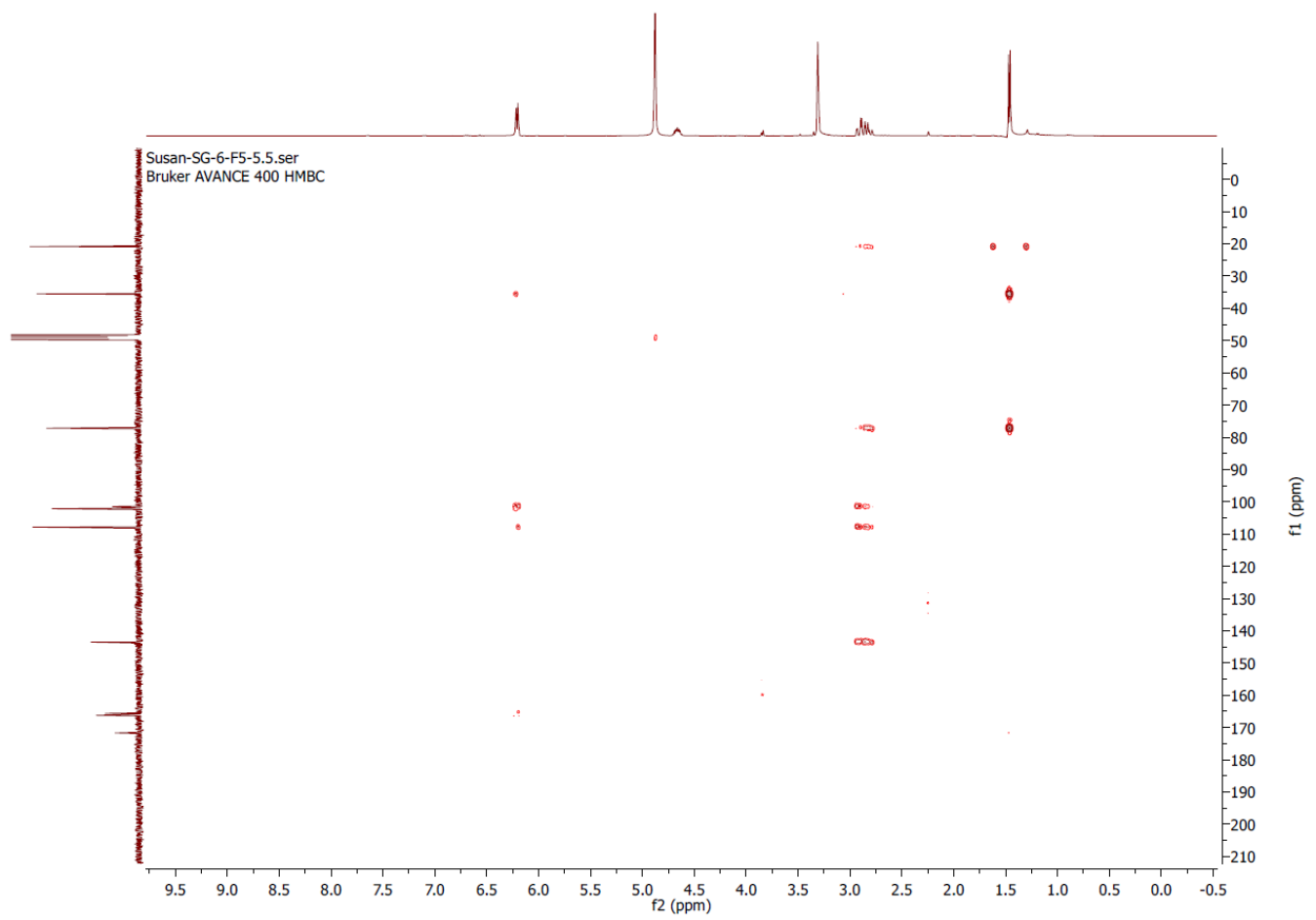


COSY of compound $6\left(\mathrm{CD}_{3} \mathrm{OD}, 400 \mathrm{MHz}\right)$

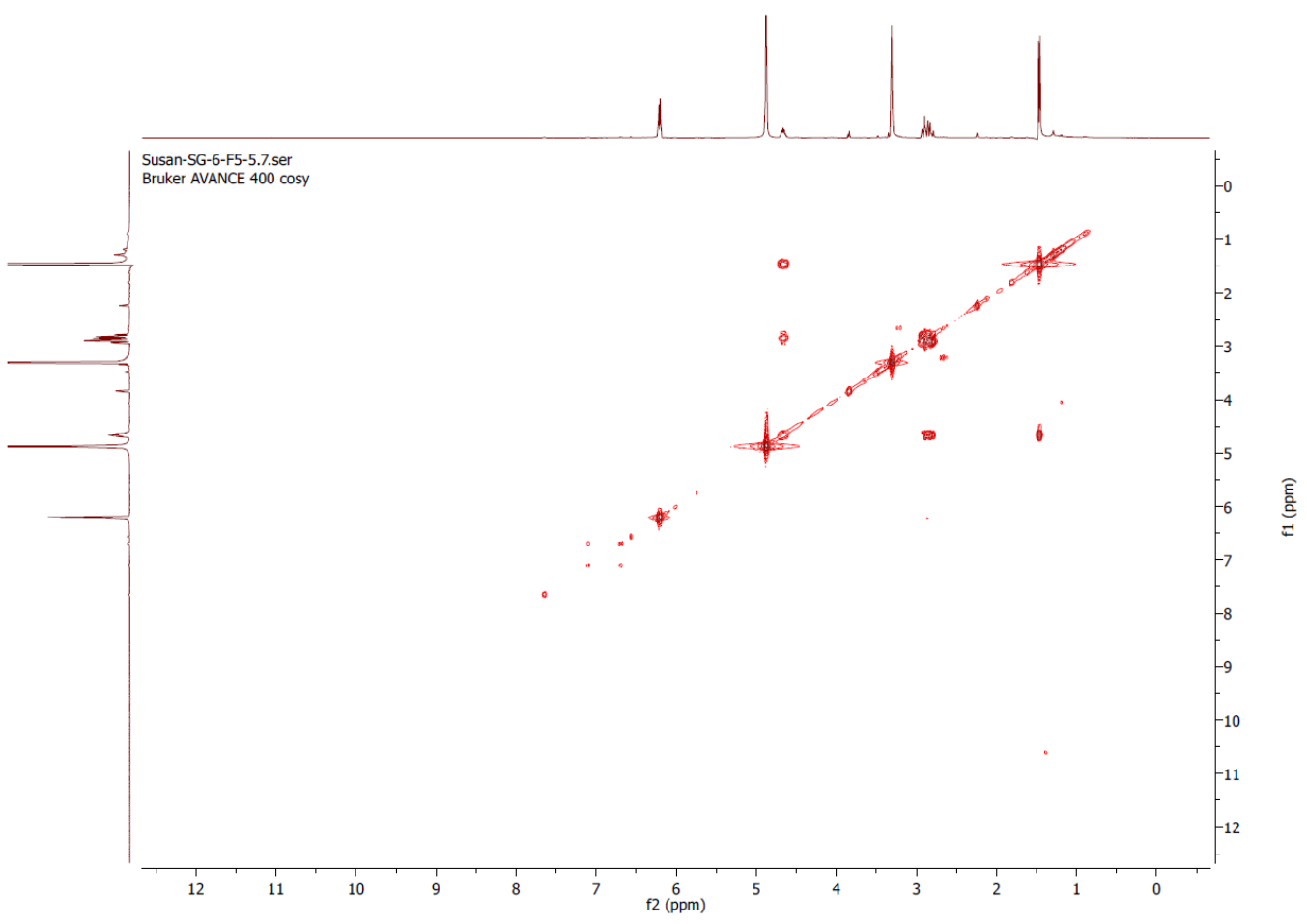

DEPT-135 of compound $6\left(\mathrm{CD}_{3} \mathrm{OD}, 100 \mathrm{MHz}\right)$

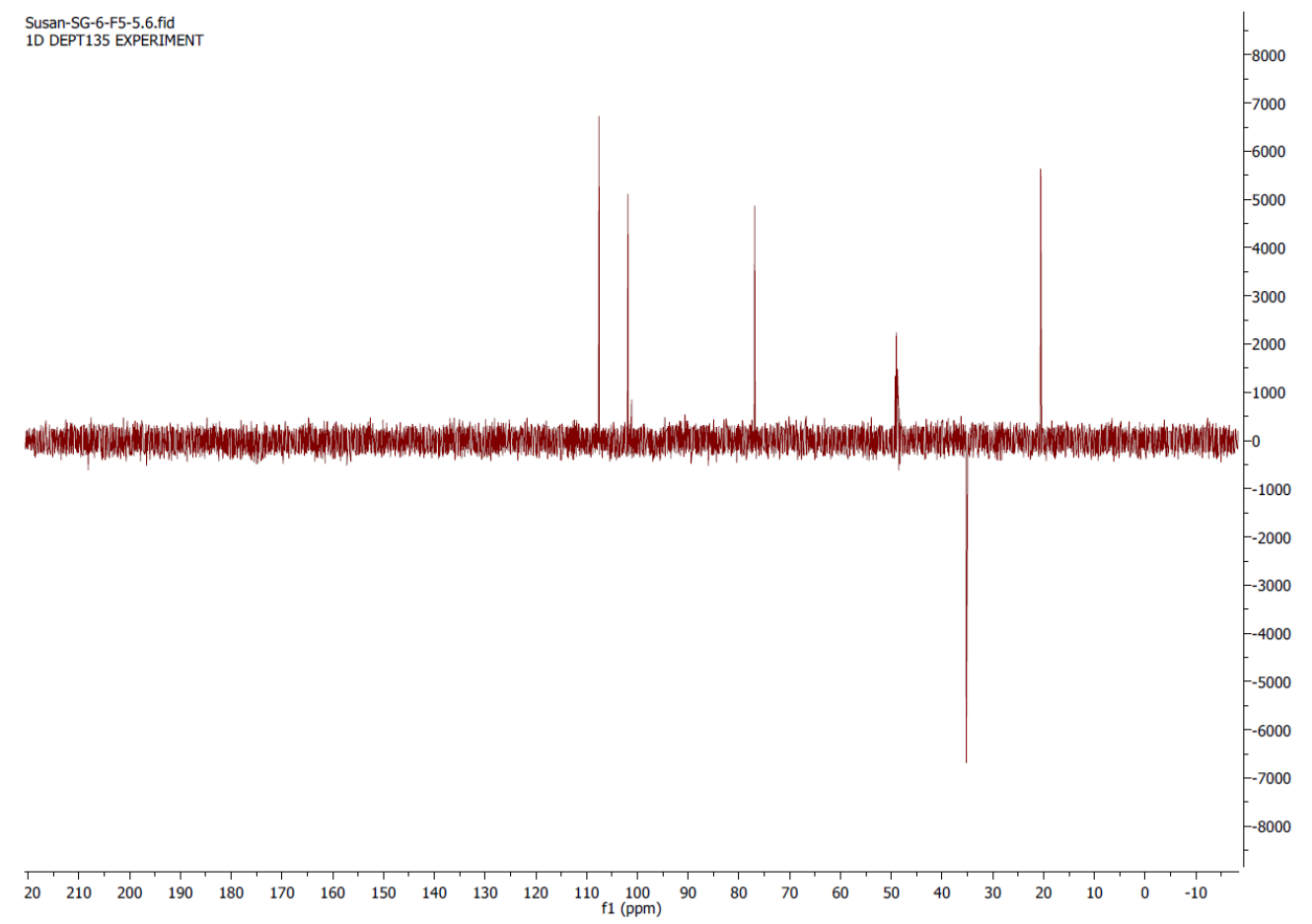


COMPOUND 7 ((R)-5,7-dichloro-6-hydroxy-2-methyl-2,3-dihydrobenzofuran-4-carboxylic acid)

Mass spectrum of compound 7

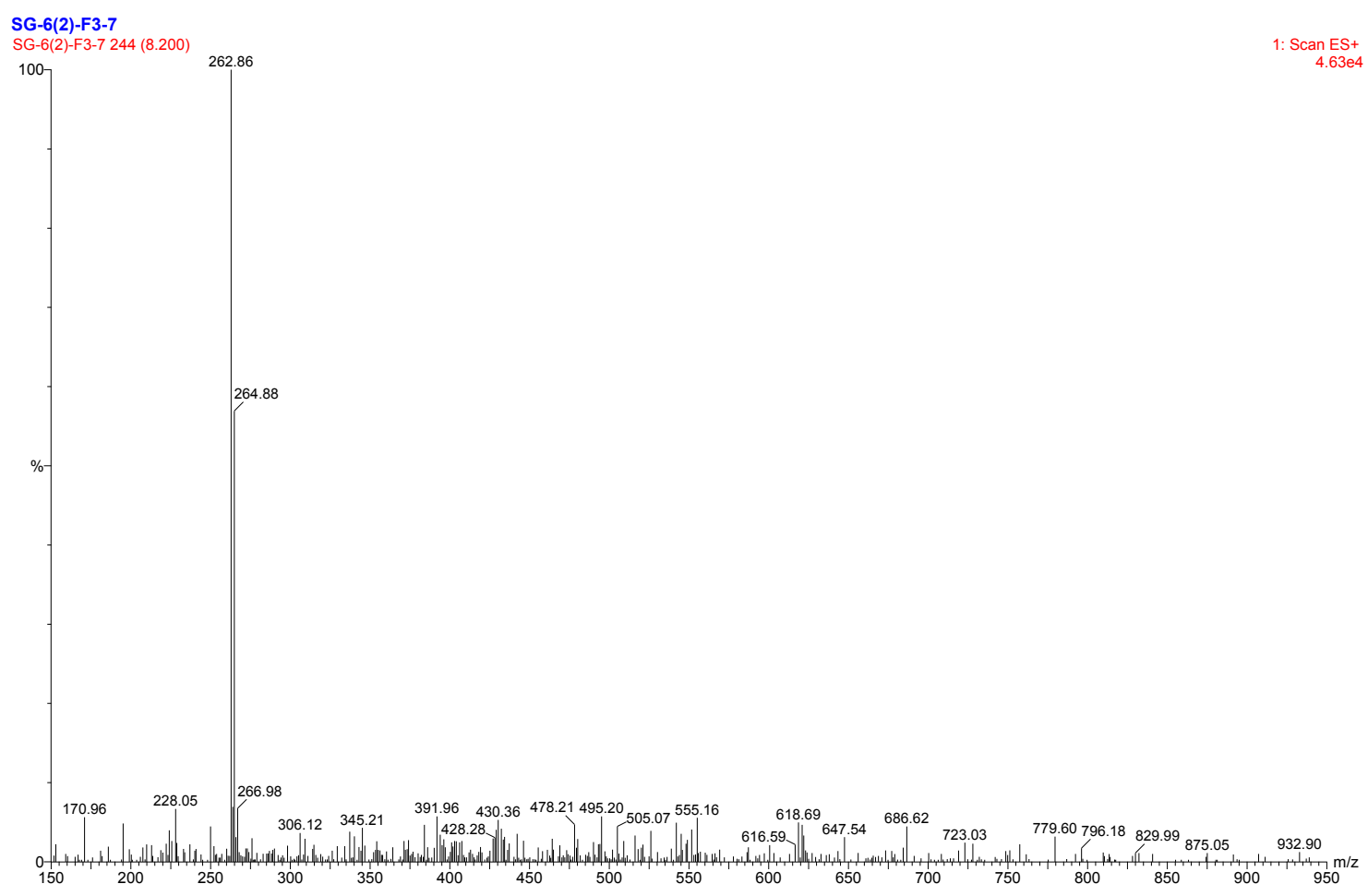

${ }^{1} \mathrm{H}$ NMR spectrum of compound $7\left(\left(\mathrm{CH}_{3}\right)_{2} \mathrm{CO}, 400 \mathrm{MHz}\right)$

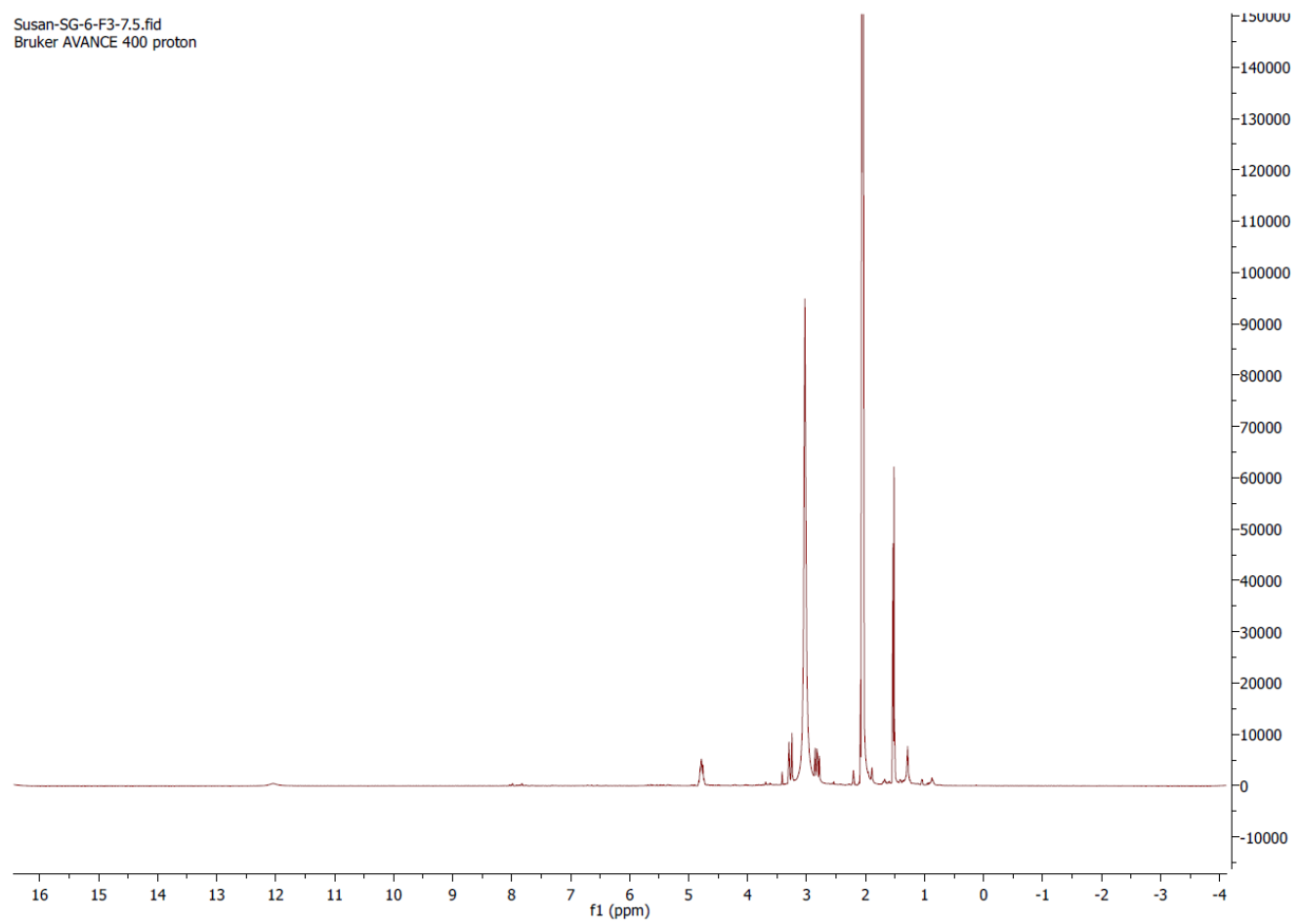


${ }^{13} \mathrm{C}$ NMR spectrum of compound $7\left(\left(\mathrm{CH}_{3}\right)_{2} \mathrm{CO}, 100 \mathrm{MHz}\right)$

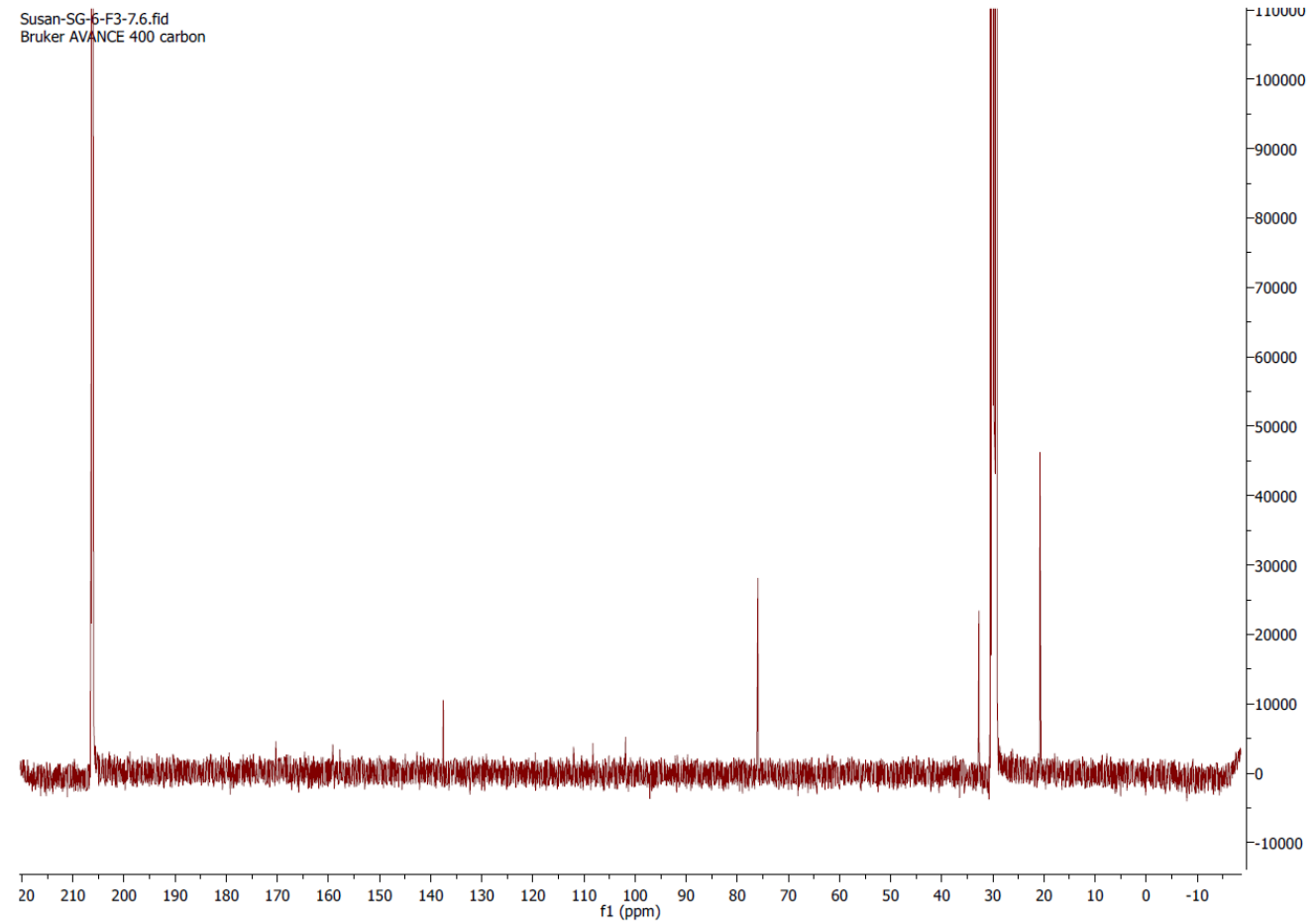

HSQC of compound $7\left(\left(\mathrm{CH}_{3}\right)_{2} \mathrm{CO}, 400 \mathrm{MHz}\right)$

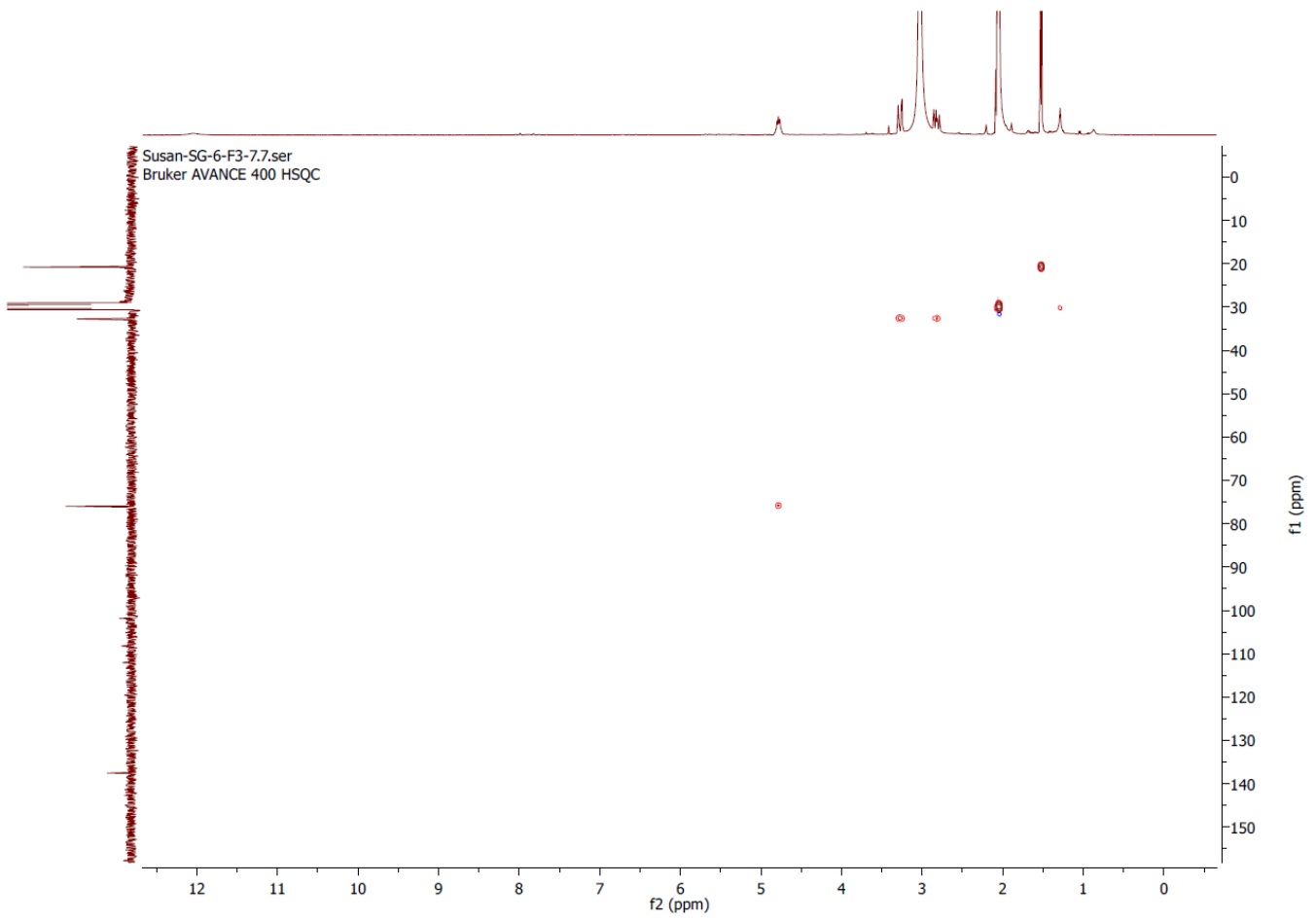


HMBC of compound $7\left(\left(\mathrm{CH}_{3}\right)_{2} \mathrm{CO}, 400 \mathrm{MHz}\right)$

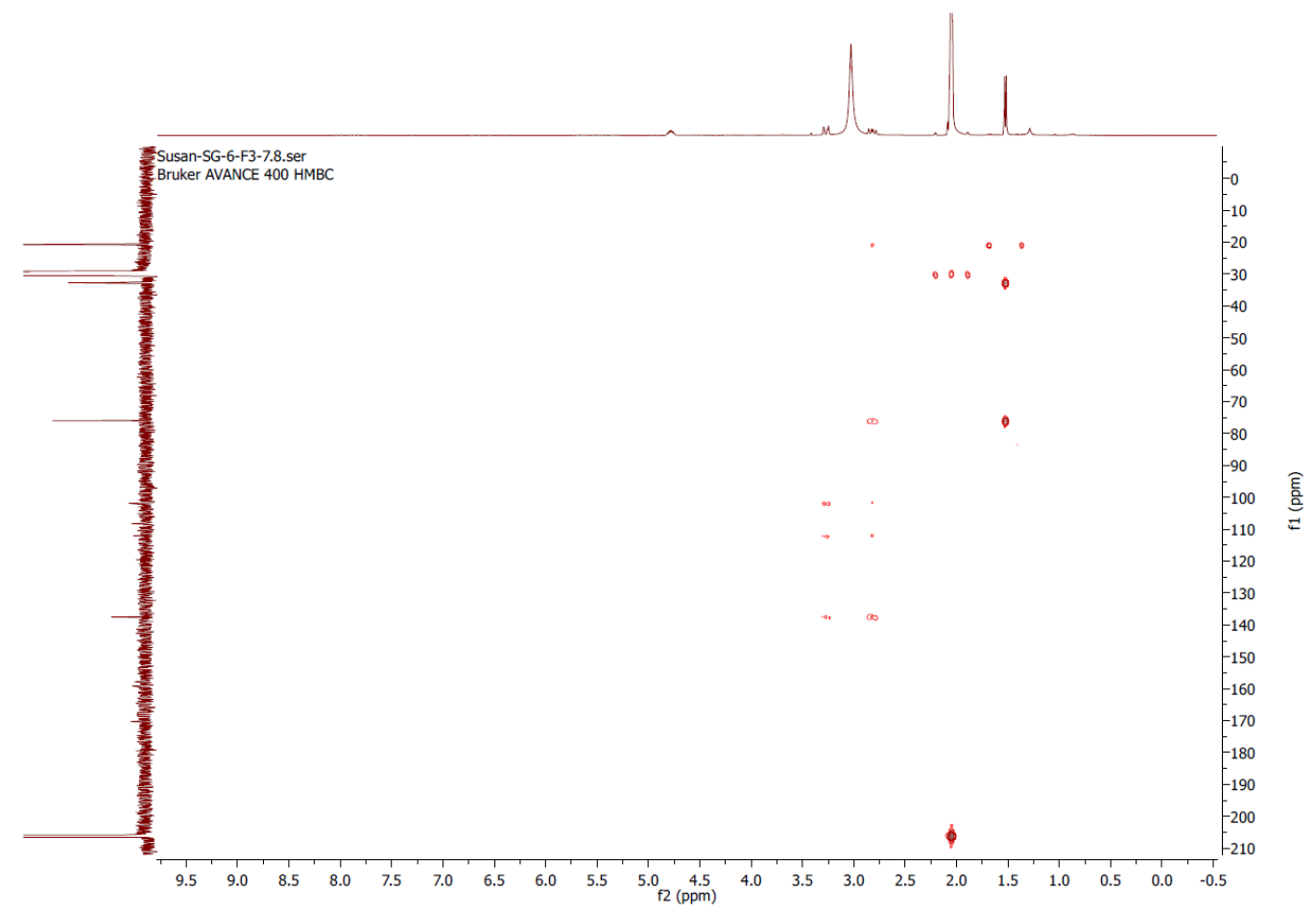

COSY of compound $7\left(\left(\mathrm{CH}_{3}\right)_{2} \mathrm{CO}, 400 \mathrm{MHz}\right)$

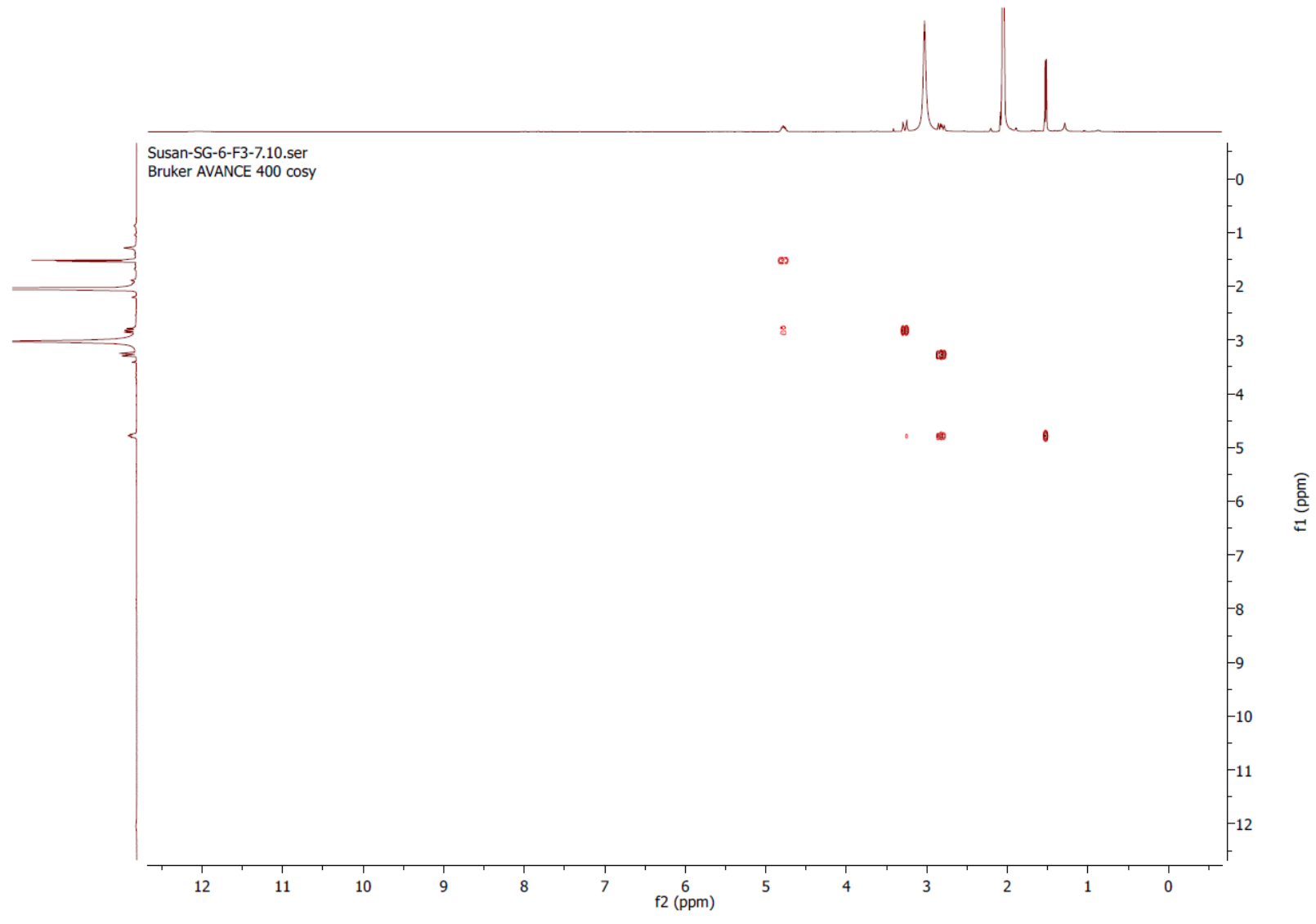


DEPT-135 of compound $7\left(\left(\mathrm{CH}_{3}\right)_{2} \mathrm{CO}, 100 \mathrm{MHz}\right)$

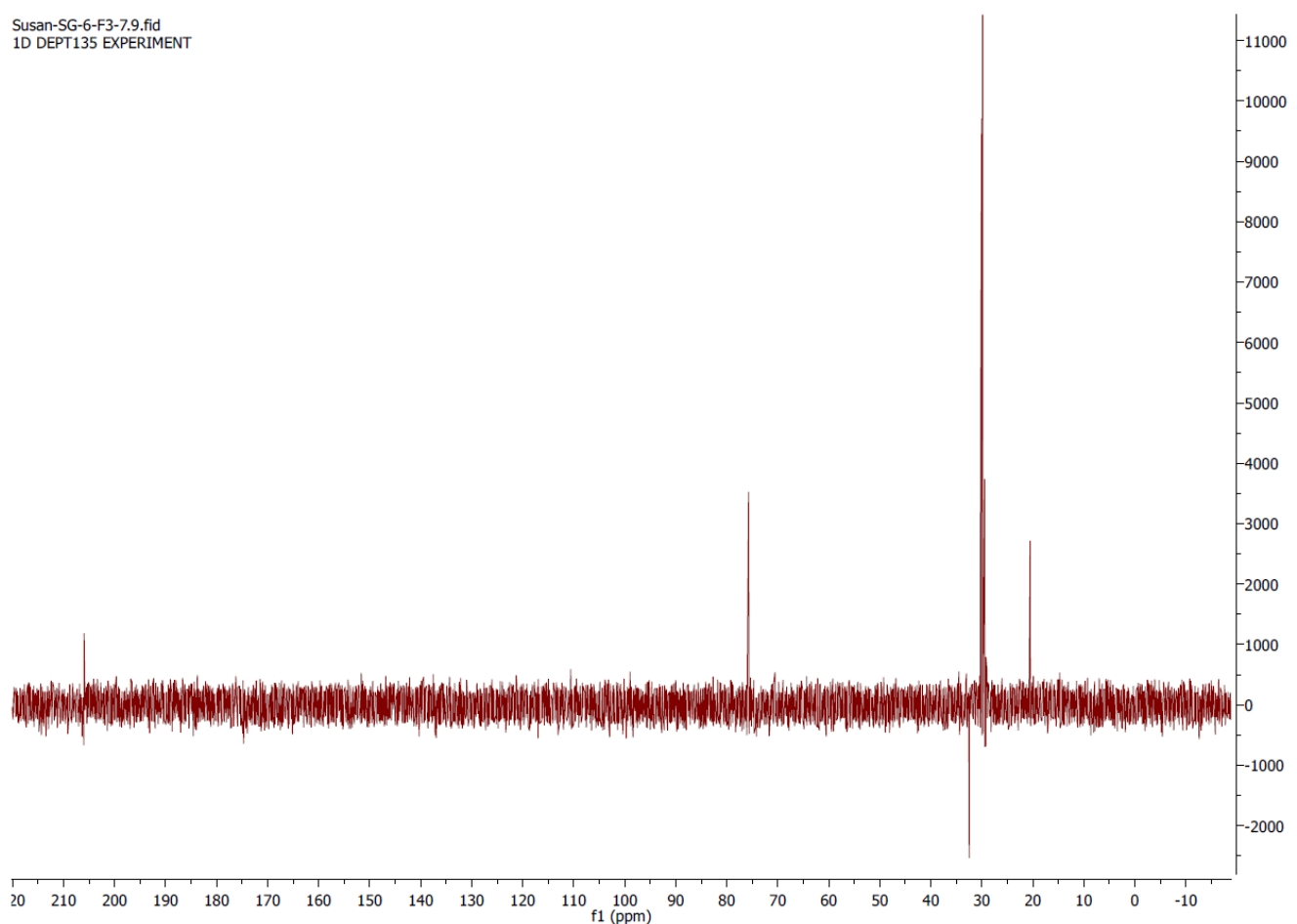

COMPOUND 7 ((R)-5,7-dichloro-6-hydroxy-2-methyl-2,3-dihydrobenzofuran-4-carboxylic acid)

Mass spectrum of compound 7

SG-6.F.5-5.6

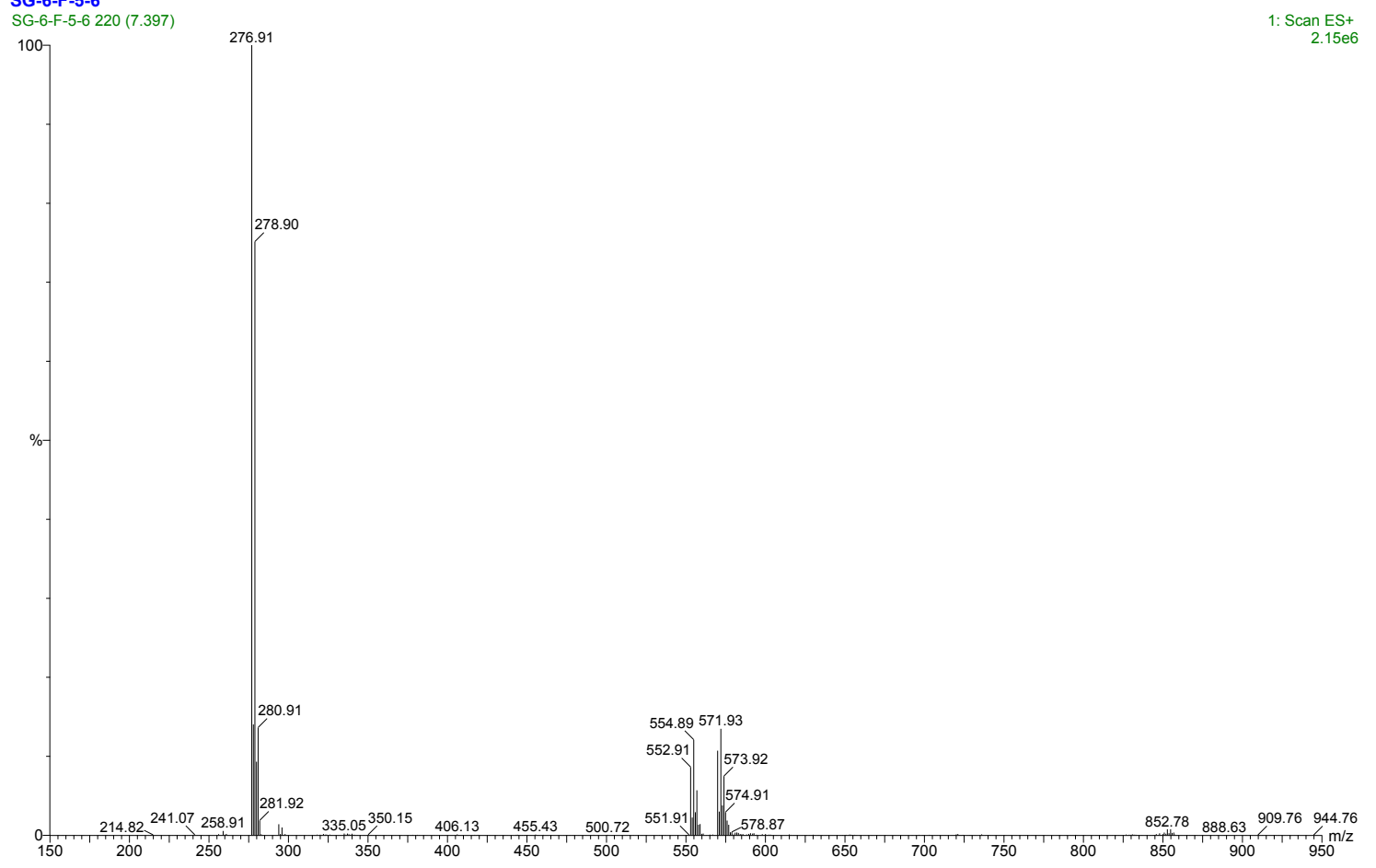


${ }^{1} \mathrm{H}$ NMR spectrum of compound $7\left(\left(\mathrm{CH}_{3}\right)_{2} \mathrm{CO}, 400 \mathrm{MHz}\right)$

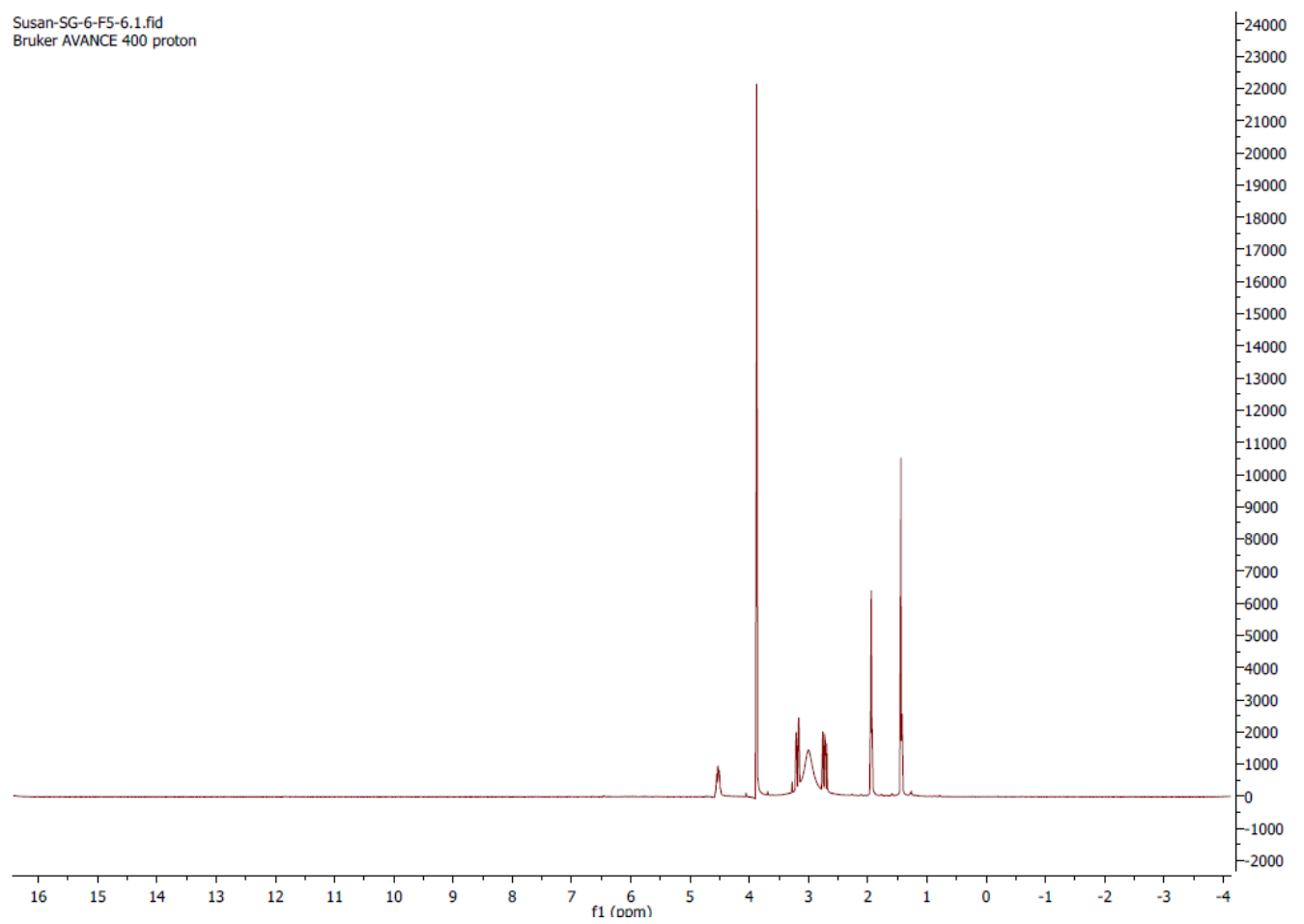

${ }^{13} \mathrm{C}$ NMR spectrum of compound $7\left(\left(\mathrm{CH}_{3}\right)_{2} \mathrm{CO}, 100 \mathrm{MHz}\right)$

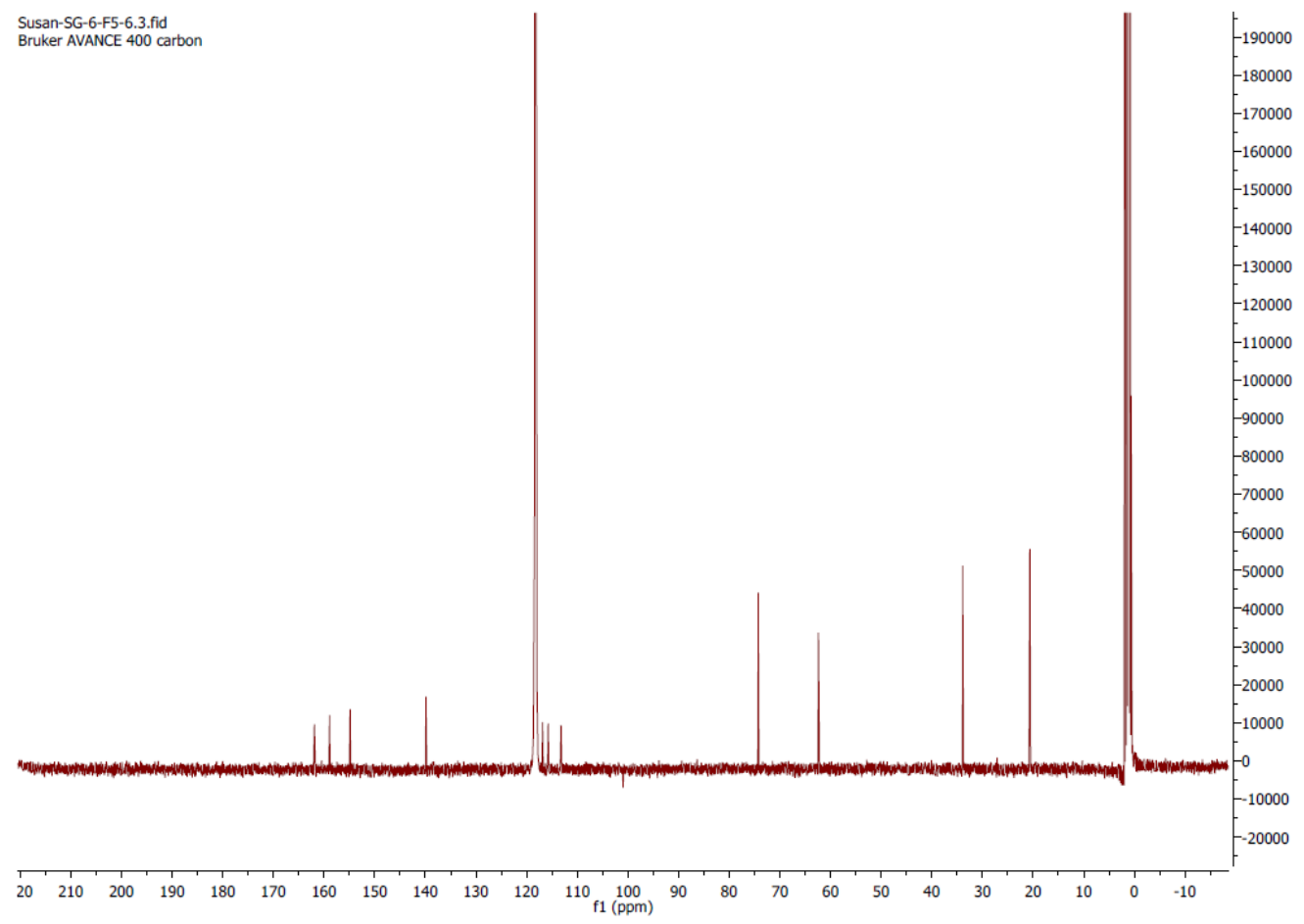


HSQC of compound $7\left(\left(\mathrm{CH}_{3}\right)_{2} \mathrm{CO}, 400 \mathrm{MHz}\right)$

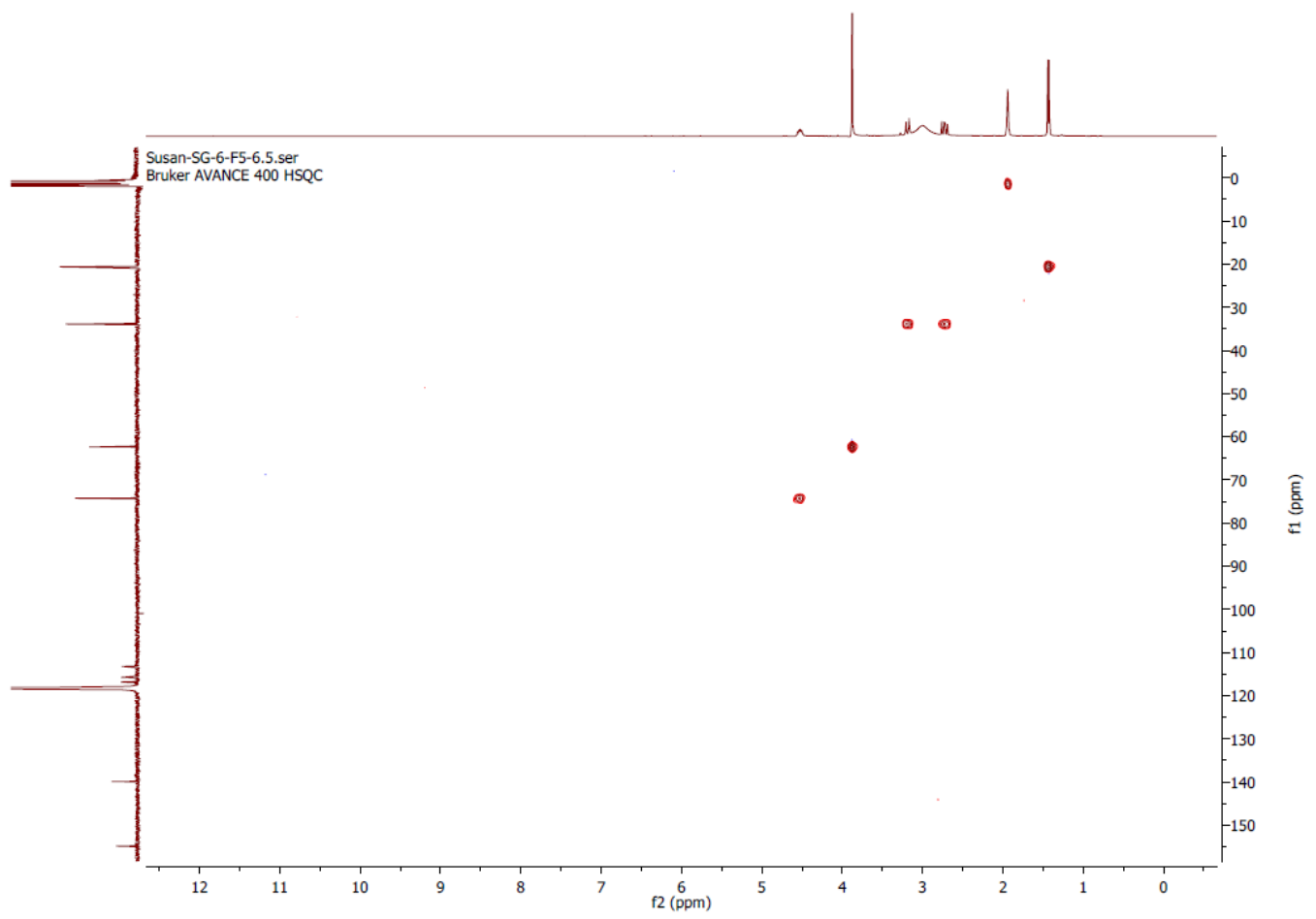

HMBC of compound $7\left(\left(\mathrm{CH}_{3}\right)_{2} \mathrm{CO}, 400 \mathrm{MHz}\right)$

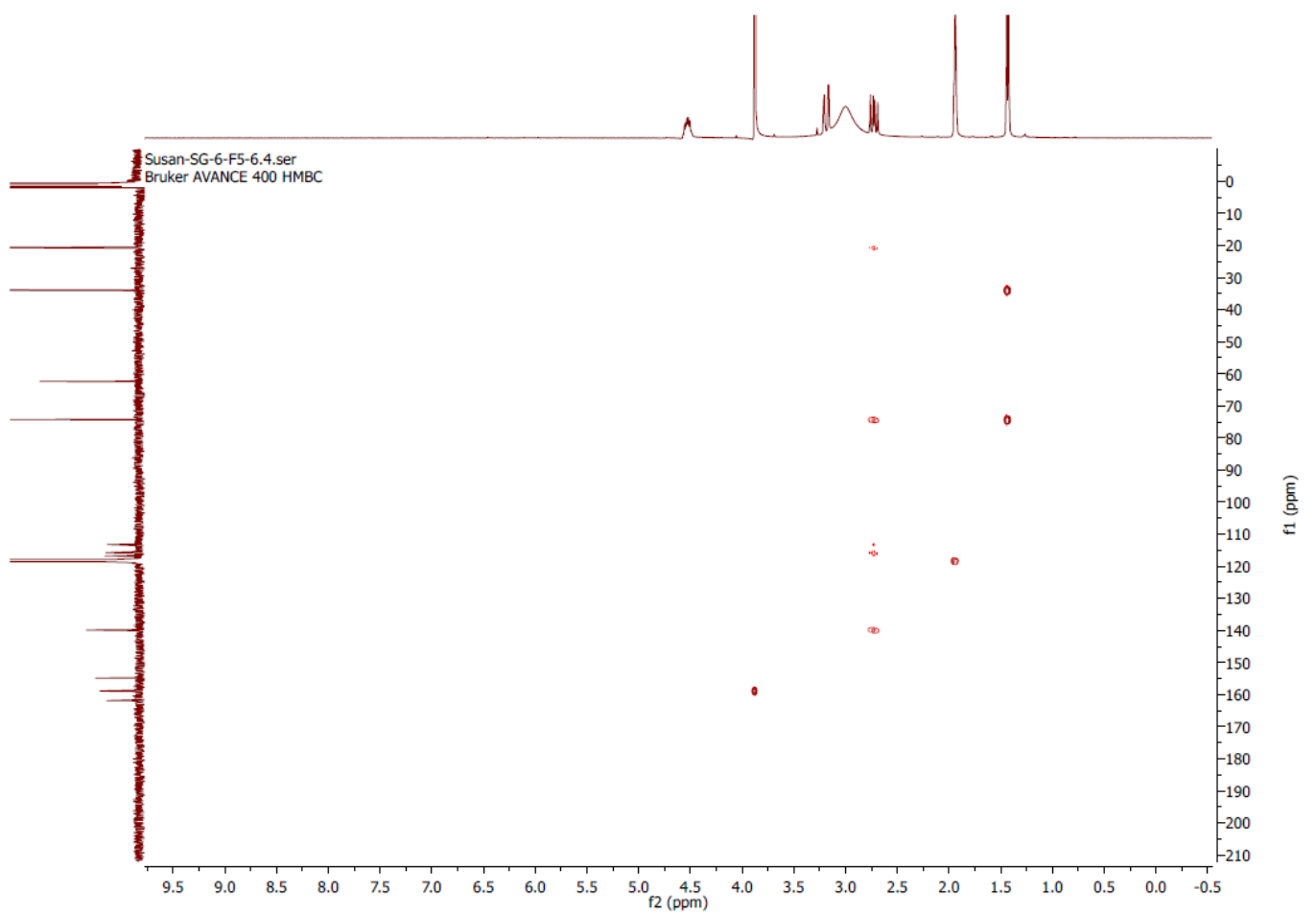


COSY of compound $7\left(\left(\mathrm{CH}_{3}\right)_{2} \mathrm{CO}, 400 \mathrm{MHz}\right)$

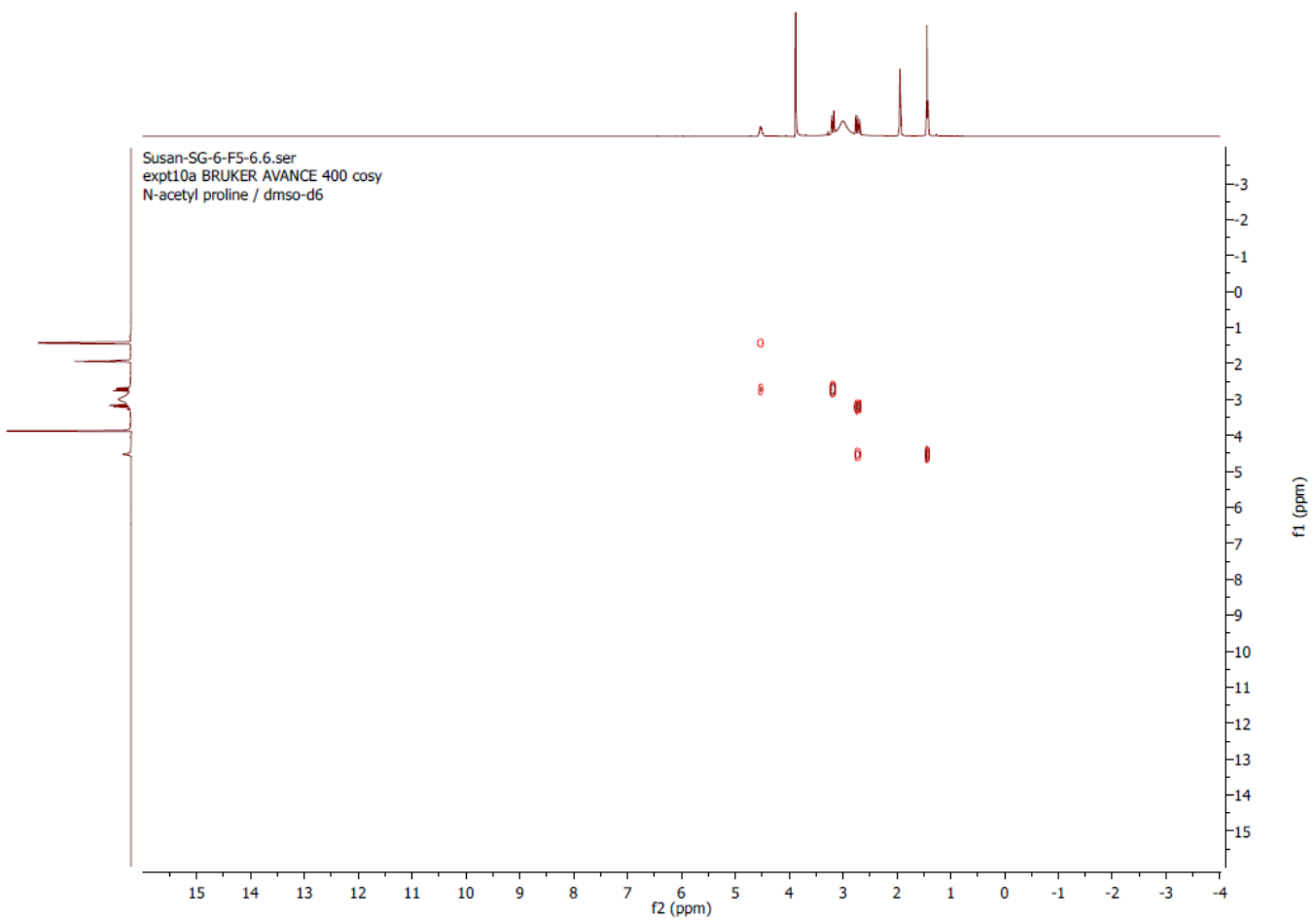

DEPT-135 of compound $7\left(\left(\mathrm{CH}_{3}\right)_{2} \mathrm{CO}, 100 \mathrm{MHz}\right)$

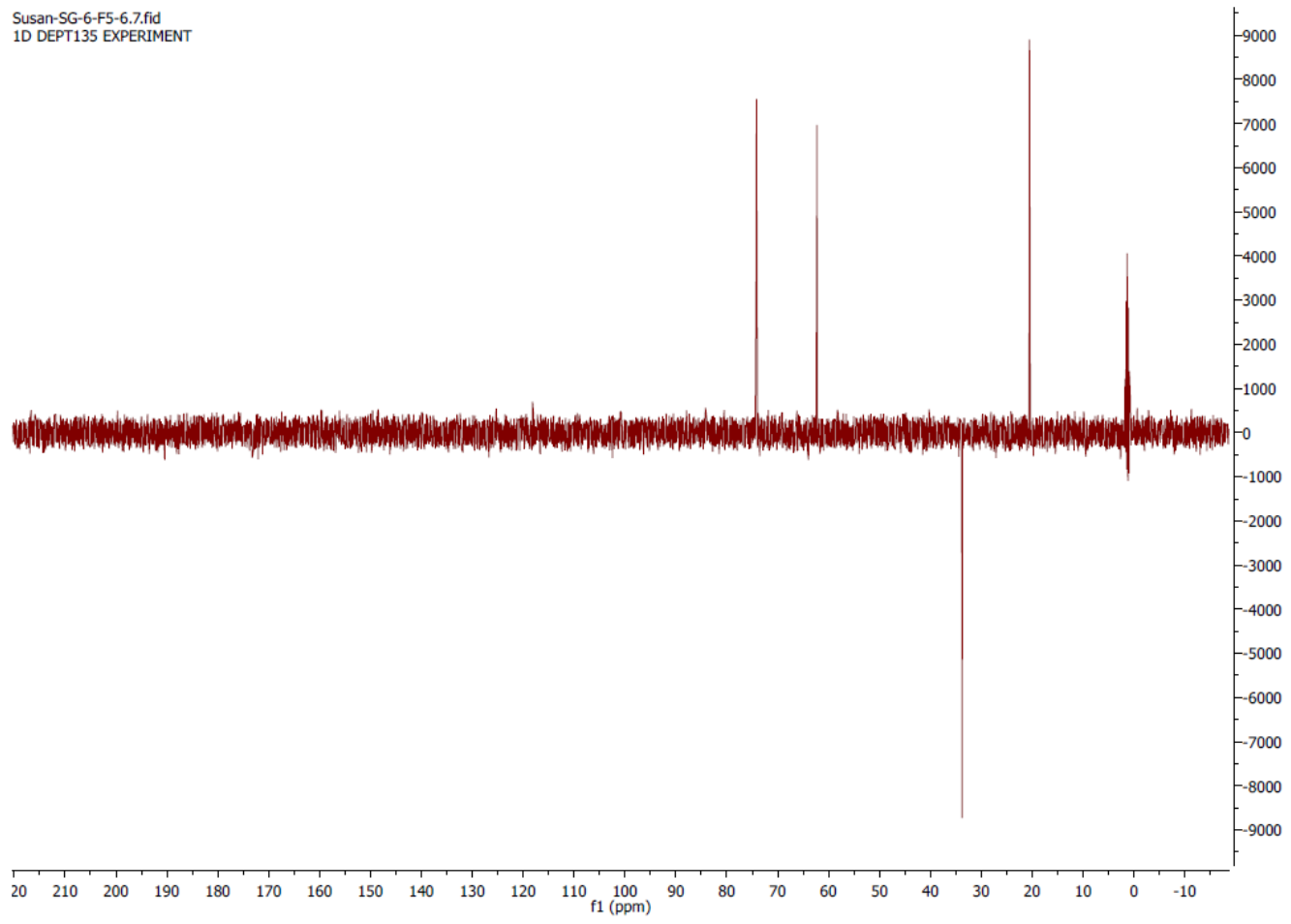


COMPOUND 8 of ((R)-5,7-dichloro-6-methoxy-2-methyl-2,3-dihydrobenzofuran-4carboxylic acid)

${ }^{1} \mathrm{H}$ NMR spectrum of compound $8\left(\left(\mathrm{CD}_{3} \mathrm{CN}\right), 400 \mathrm{MHz}\right)$

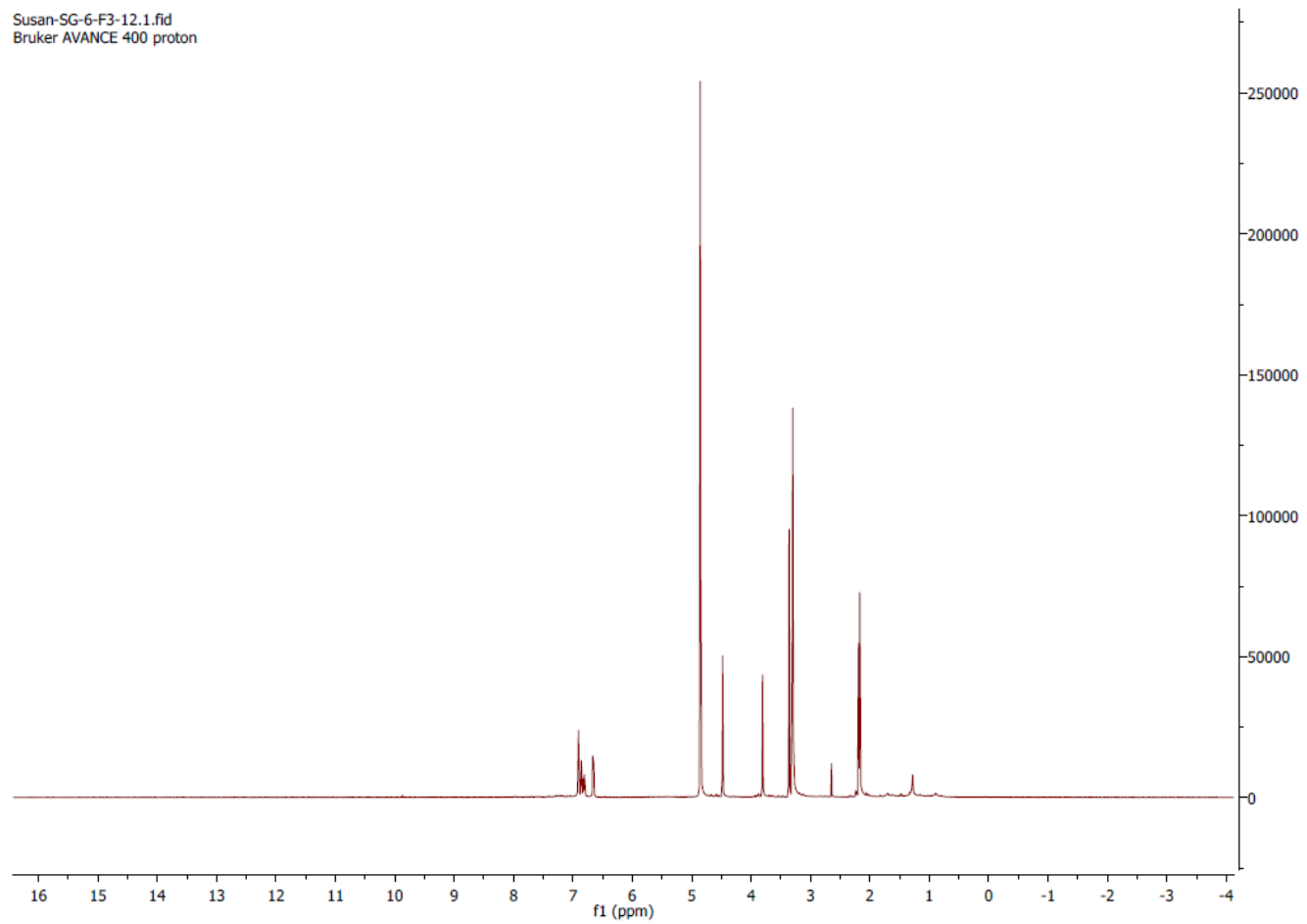

${ }^{13} \mathrm{C}$ NMR spectrum of compound $8\left(\left(\mathrm{CD}_{3} \mathrm{CN}\right), 100 \mathrm{MHz}\right)$

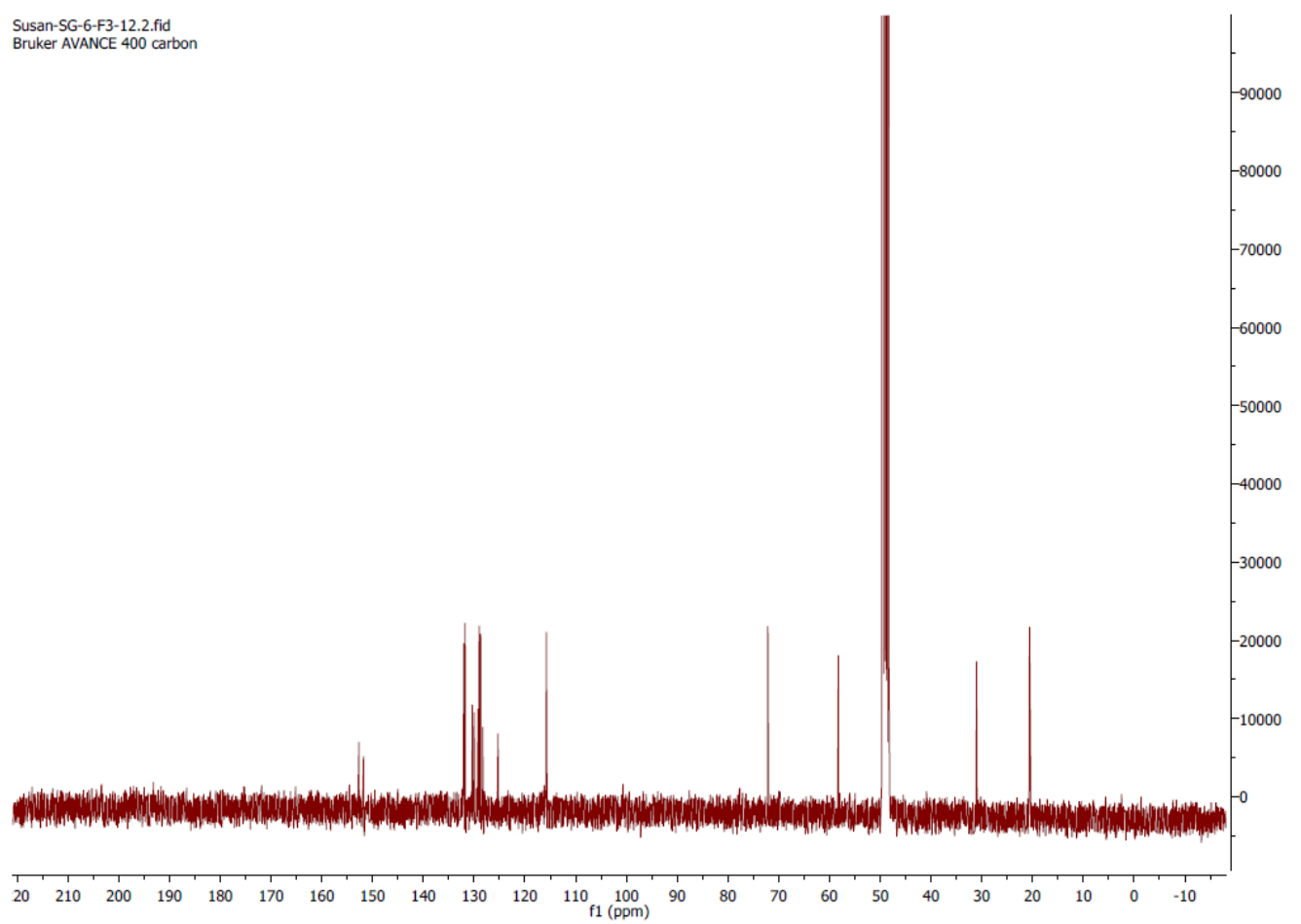


HSQC of compound $8\left(\left(\mathrm{CD}_{3} \mathrm{CN}\right), 400 \mathrm{MHz}\right)$

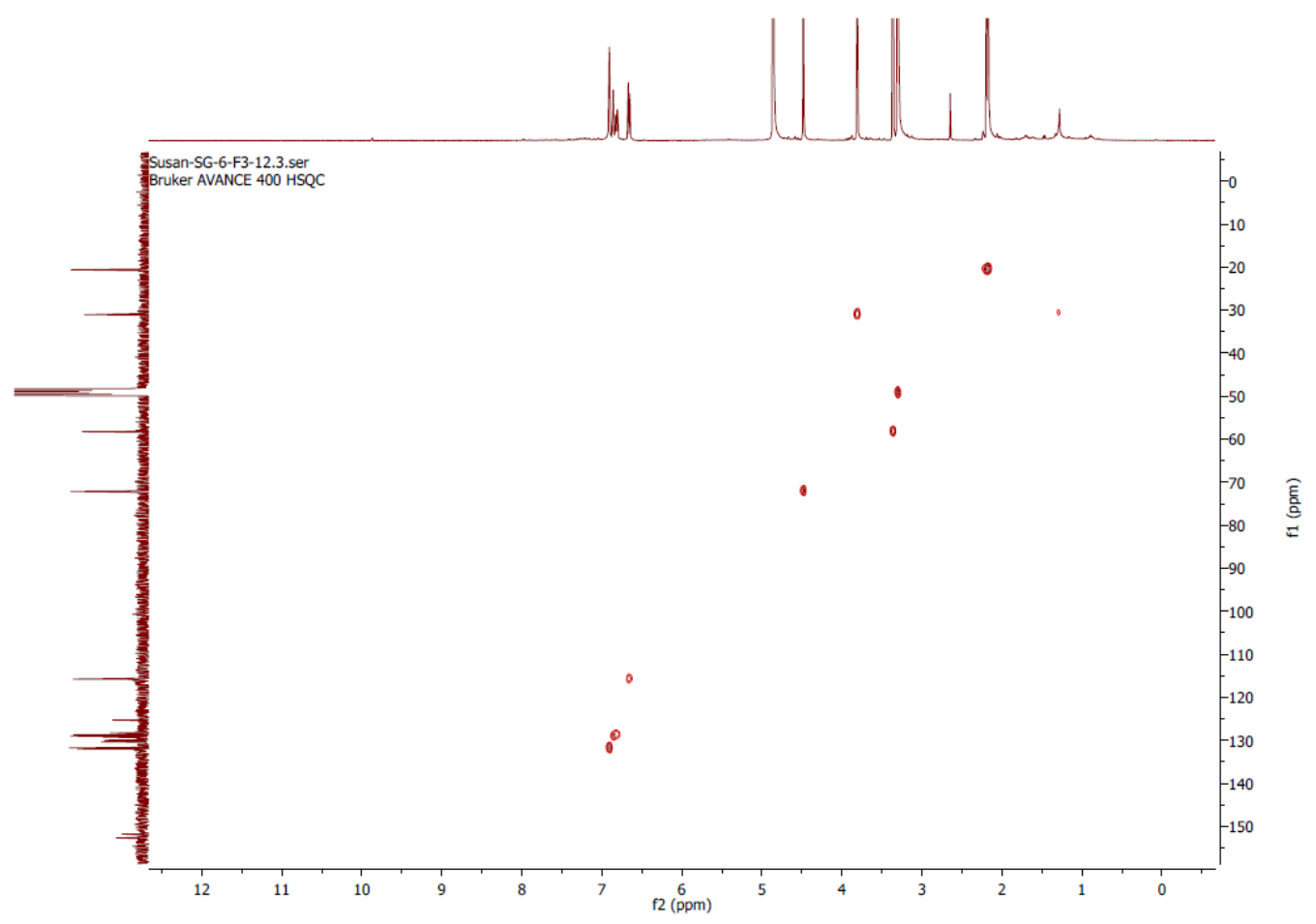

HMBC of compound $8\left(\left(\mathrm{CD}_{3} \mathrm{CN}\right), 400 \mathrm{MHz}\right)$

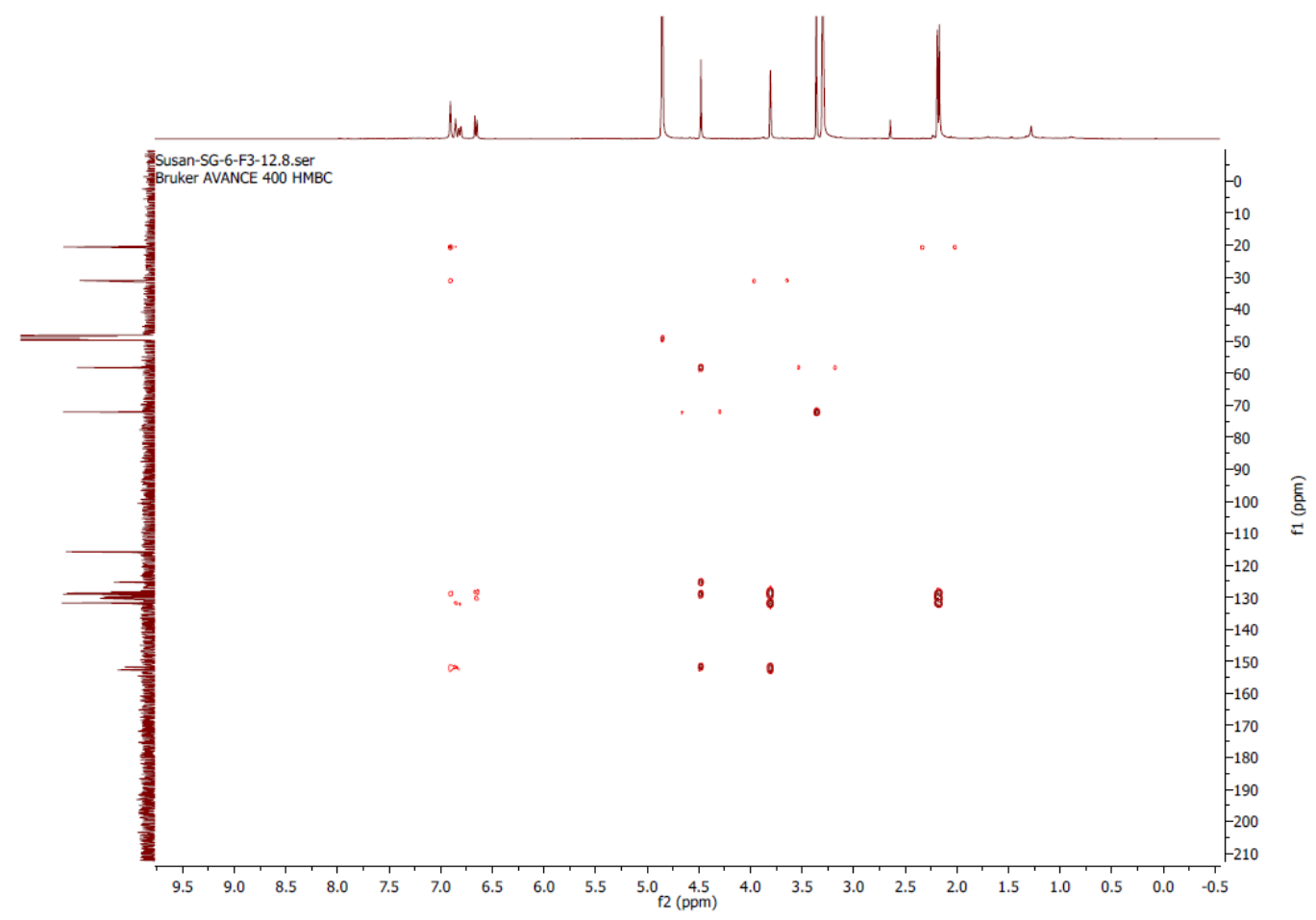


COSY of compound $8\left(\left(\mathrm{CD}_{3} \mathrm{CN}\right), 400 \mathrm{MHz}\right)$

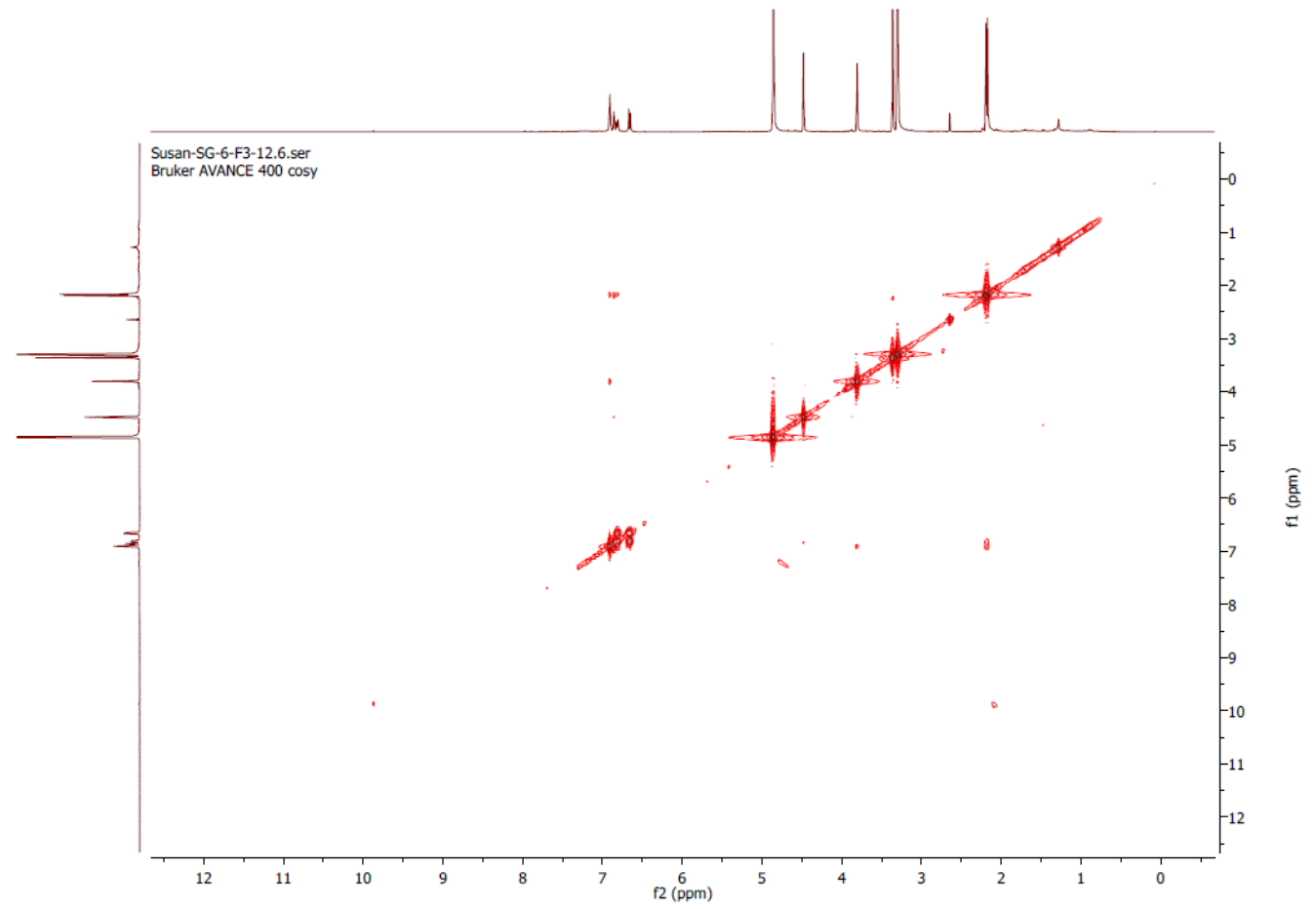

DEPT-135 of compound $8\left(\left(\mathrm{CD}_{3} \mathrm{CN}\right), 100 \mathrm{MHz}\right)$

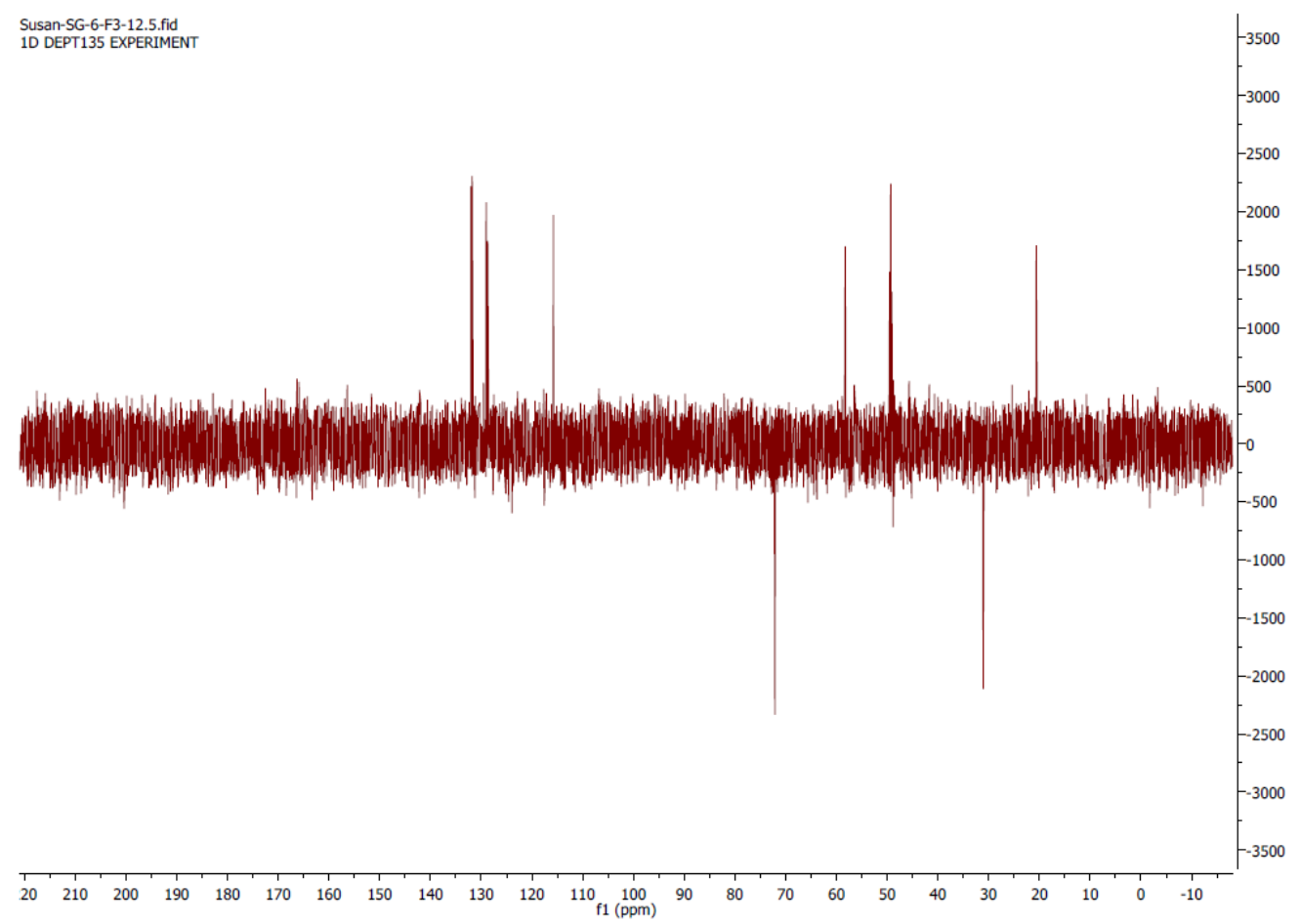




\section{COMPOUND 9 of (4-(methoxymethyl)-2-7-dimethyl-9H-xanthene)}

${ }^{1} \mathrm{H}$ NMR spectrum of compound 9 ((CD $\left.\left.\mathrm{CD}_{3} \mathrm{OD}\right), 400 \mathrm{MHz}\right)$

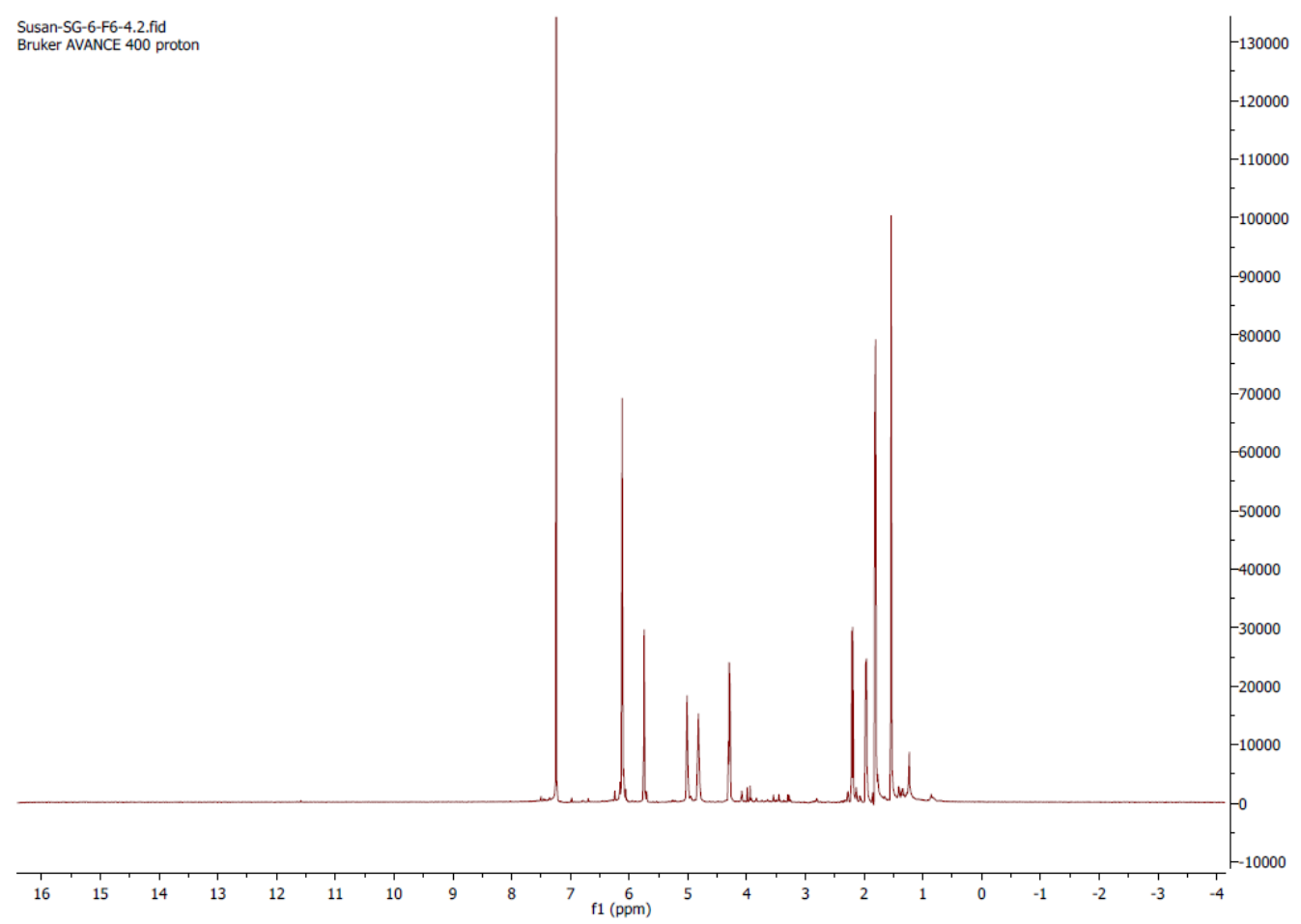

${ }^{13} \mathrm{C}$ NMR spectrum of compound $9\left(\left(\mathrm{CD}_{3} \mathrm{OD}\right), 100 \mathrm{MHz}\right)$

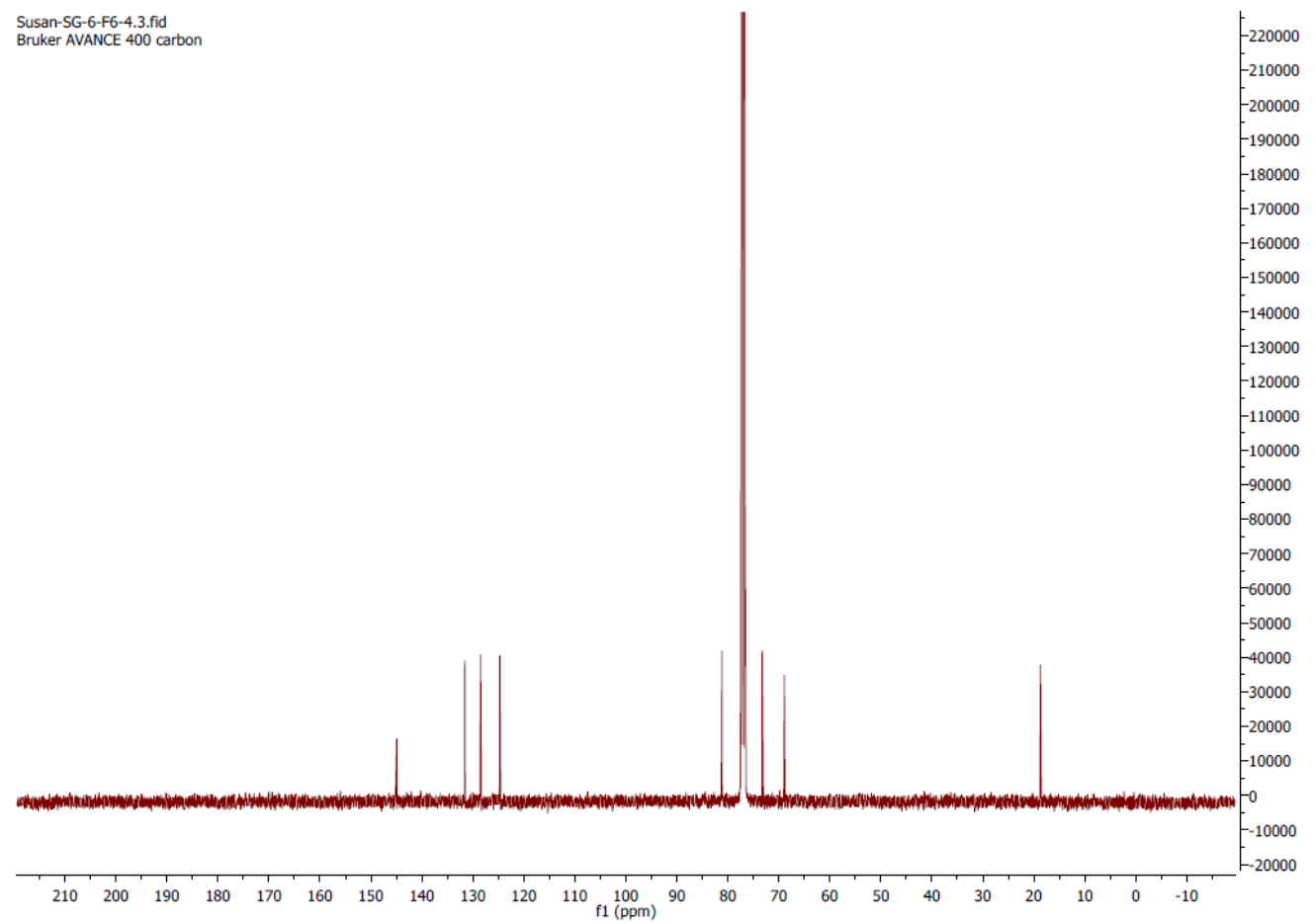


HSQC of compound $9\left(\mathrm{CD}_{3} \mathrm{OD}, 400 \mathrm{MHz}\right)$

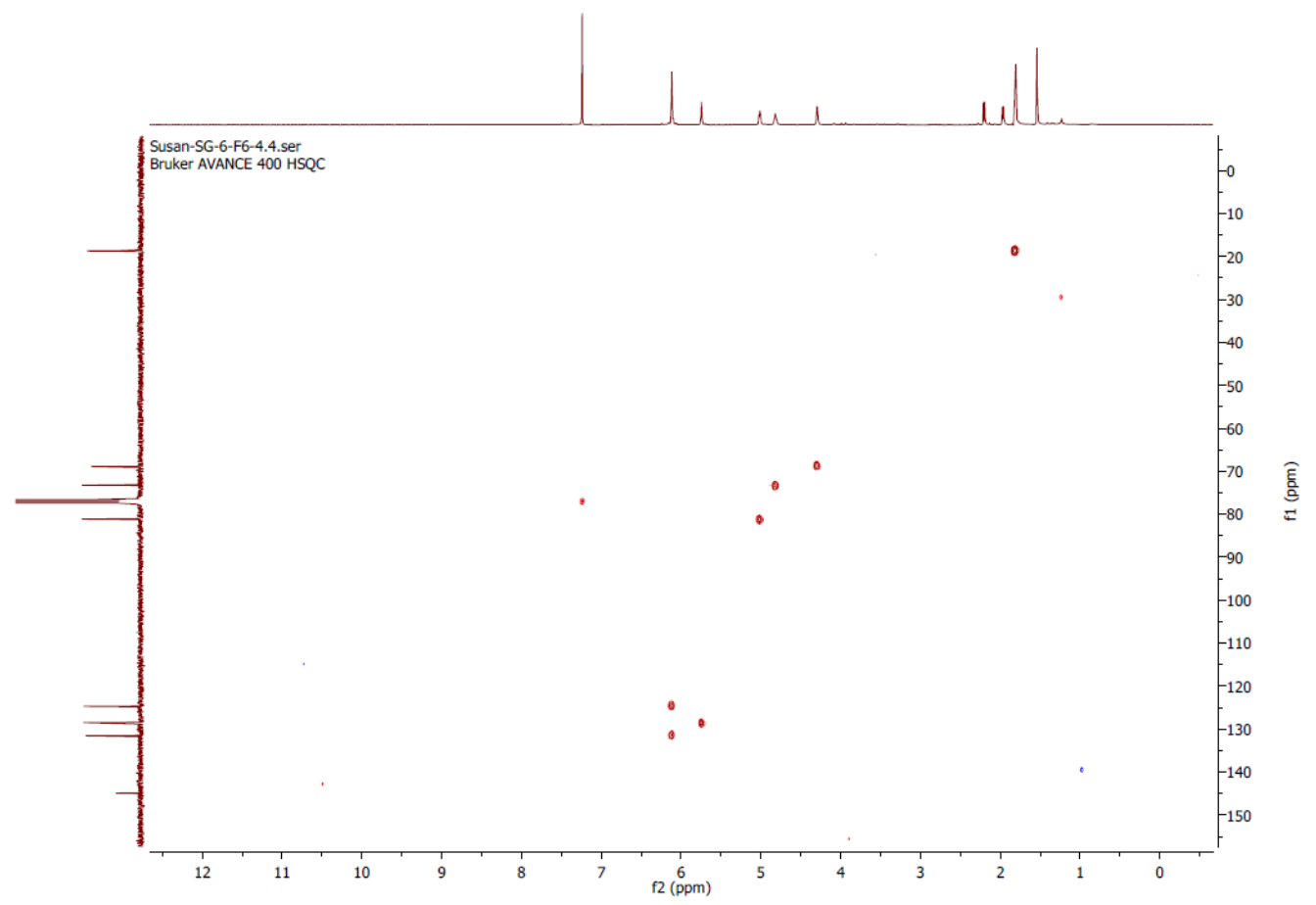

HMBC of compound $9\left(\mathrm{CD}_{3} \mathrm{OD}, 400 \mathrm{MHz}\right)$

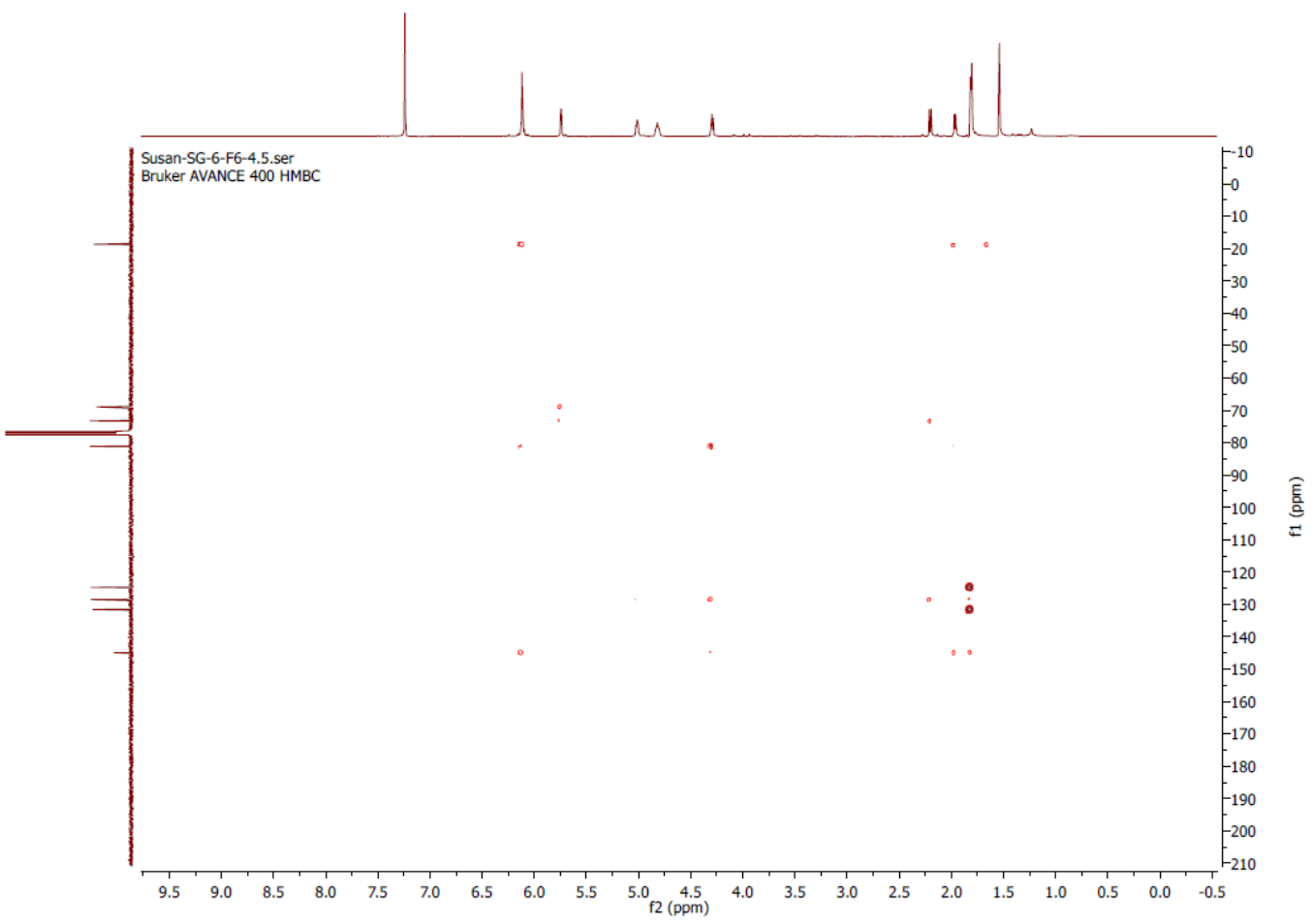


COSY of compound $9\left(\mathrm{CD}_{3} \mathrm{OD}, 400 \mathrm{MHz}\right)$

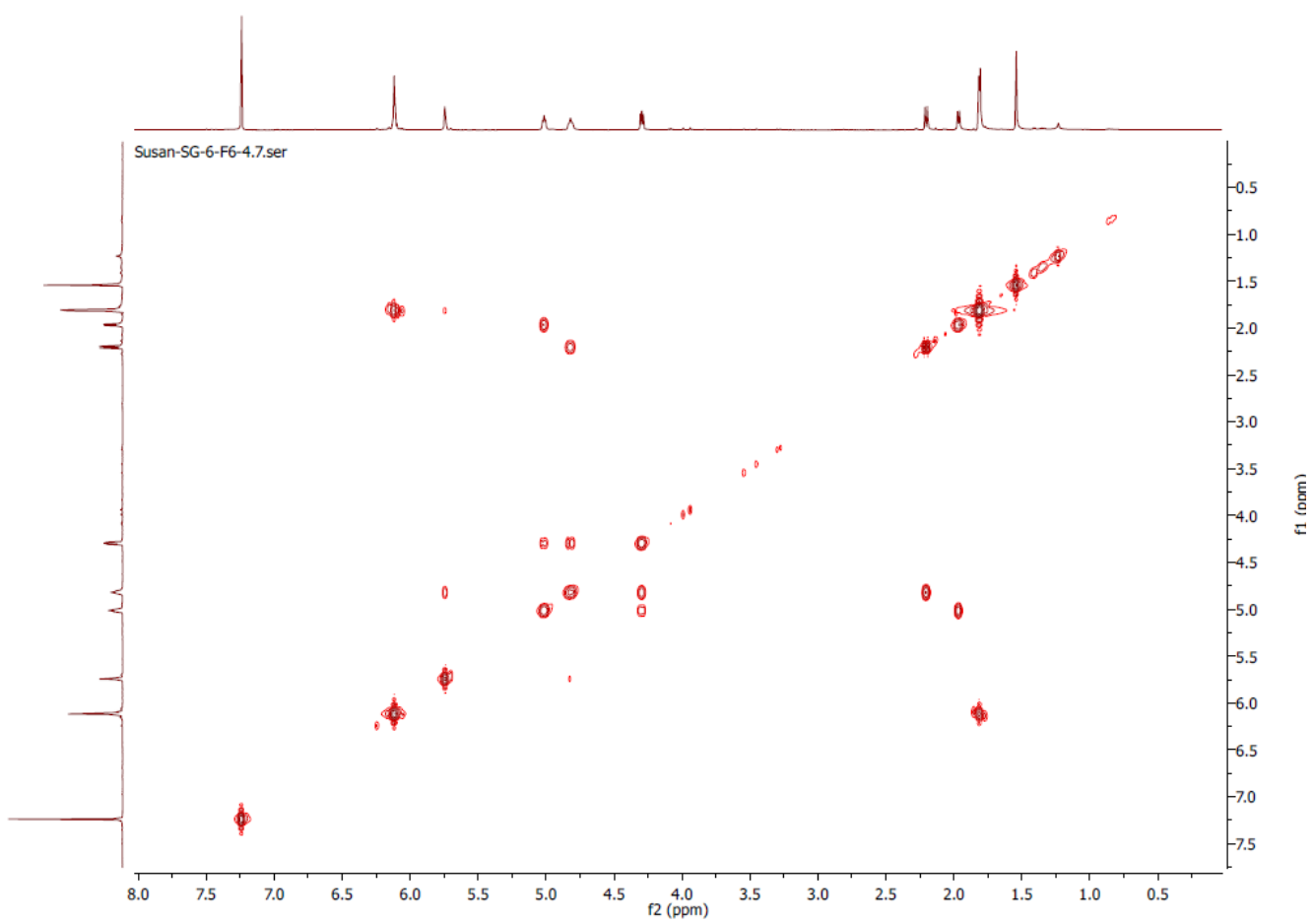

DEPT-135 of compound $9\left(\mathrm{CD}_{3} \mathrm{OD}, 100 \mathrm{MHz}\right)$

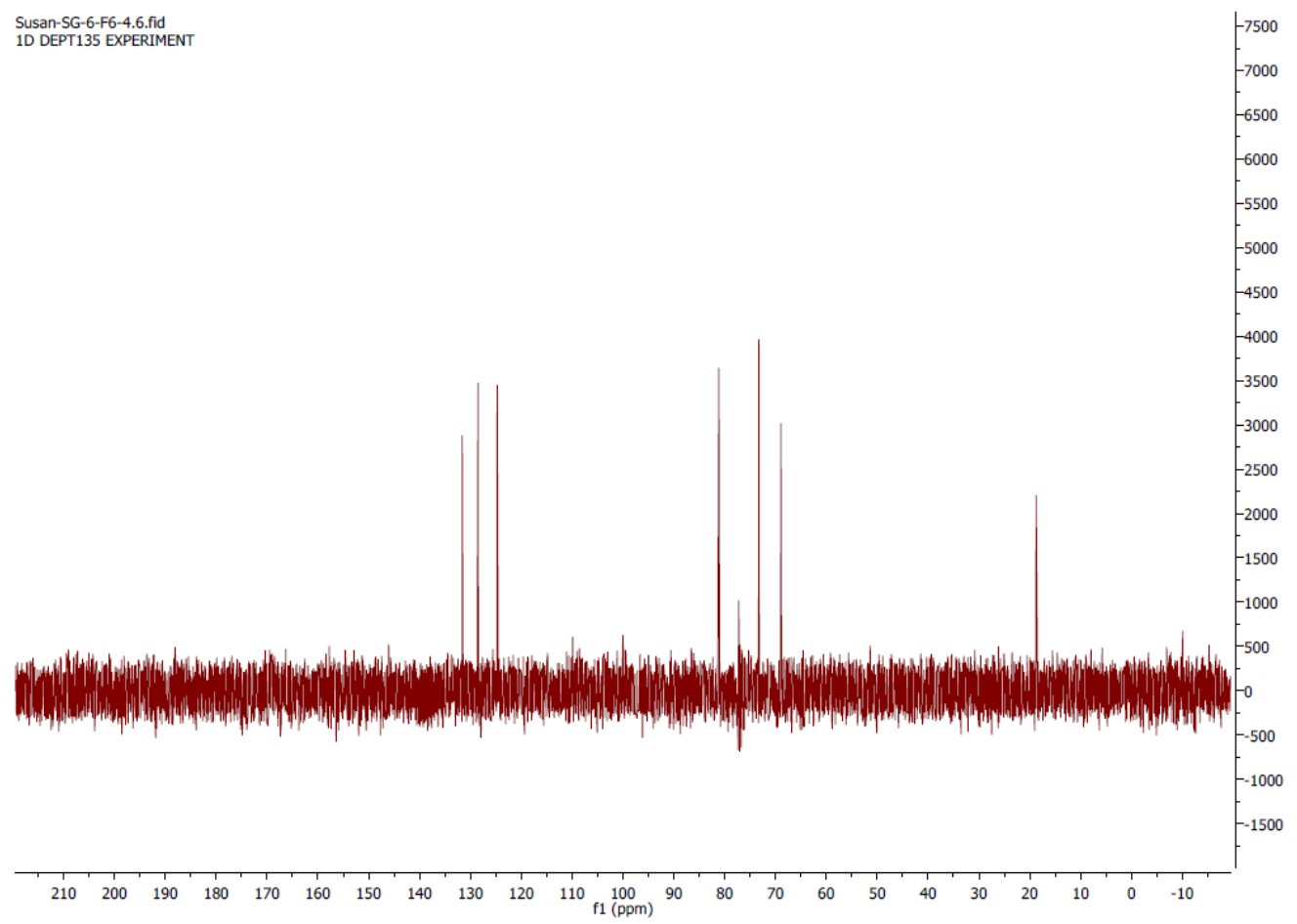




\section{COMPOUND 10 of (6-ethylidenecyclohex-4-ene-1,2,3-triol (10)}

${ }^{1} \mathrm{H}$ NMR spectrum of compound $\mathbf{1 0}\left(\left(\mathrm{CDCl}_{3}\right), 400 \mathrm{MHz}\right)$

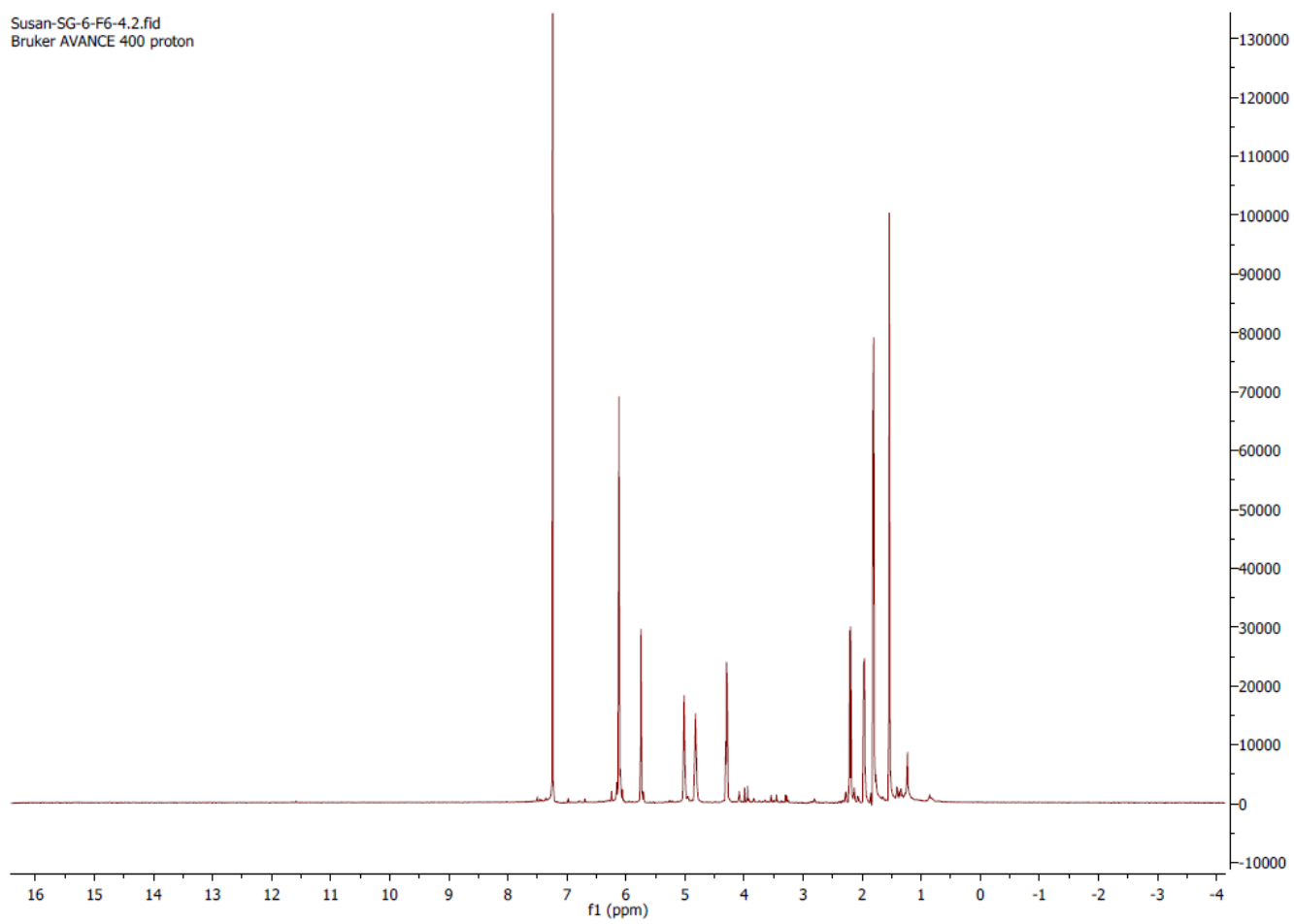

${ }^{13} \mathrm{C}$ NMR spectrum of compound $\mathbf{1 0}\left(\left(\mathrm{CDCl}_{3}\right), 100 \mathrm{MHz}\right)$

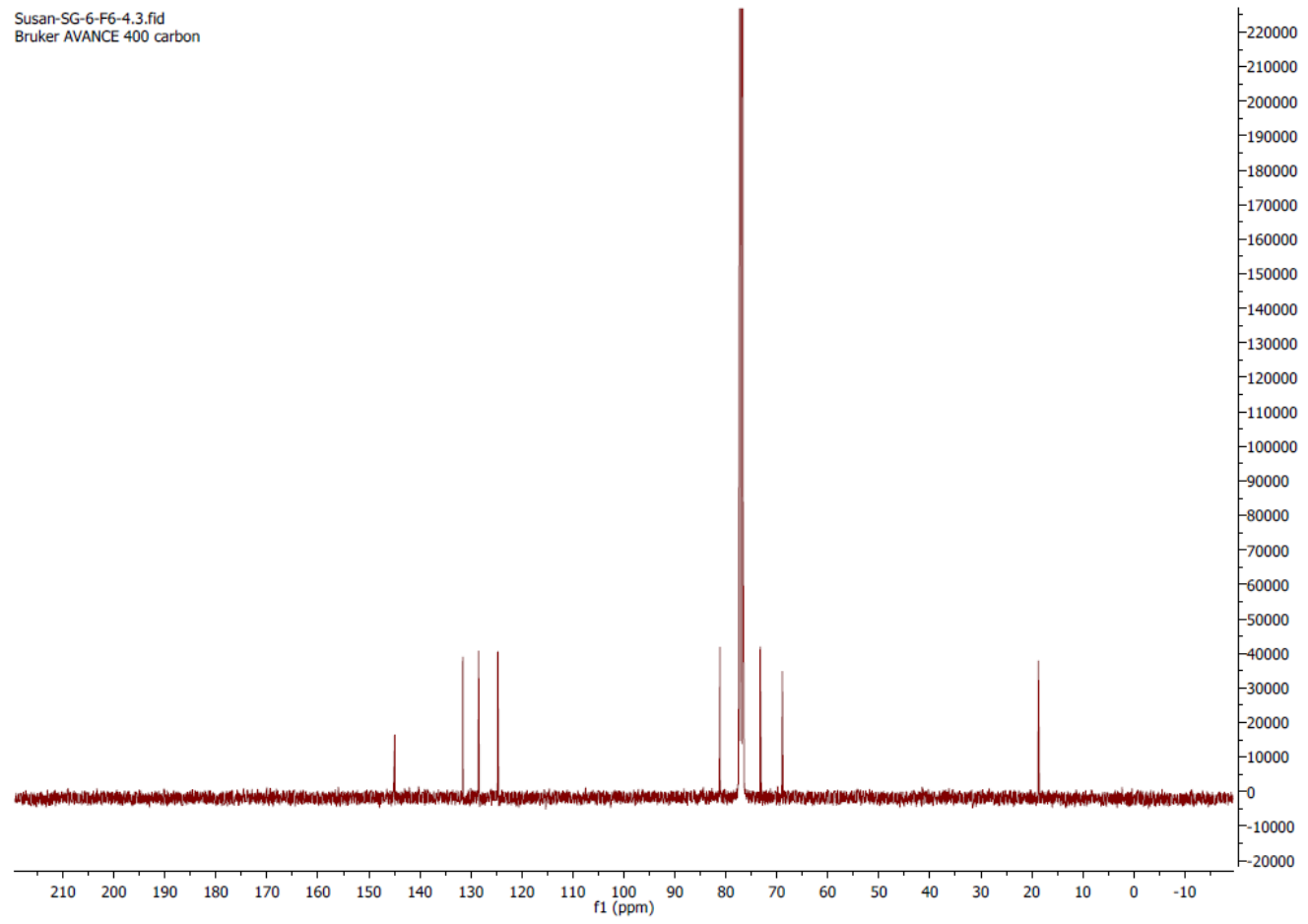


HSQC of compound $\mathbf{1 0}\left(\mathrm{CDCl}_{3}, 400 \mathrm{MHz}\right)$

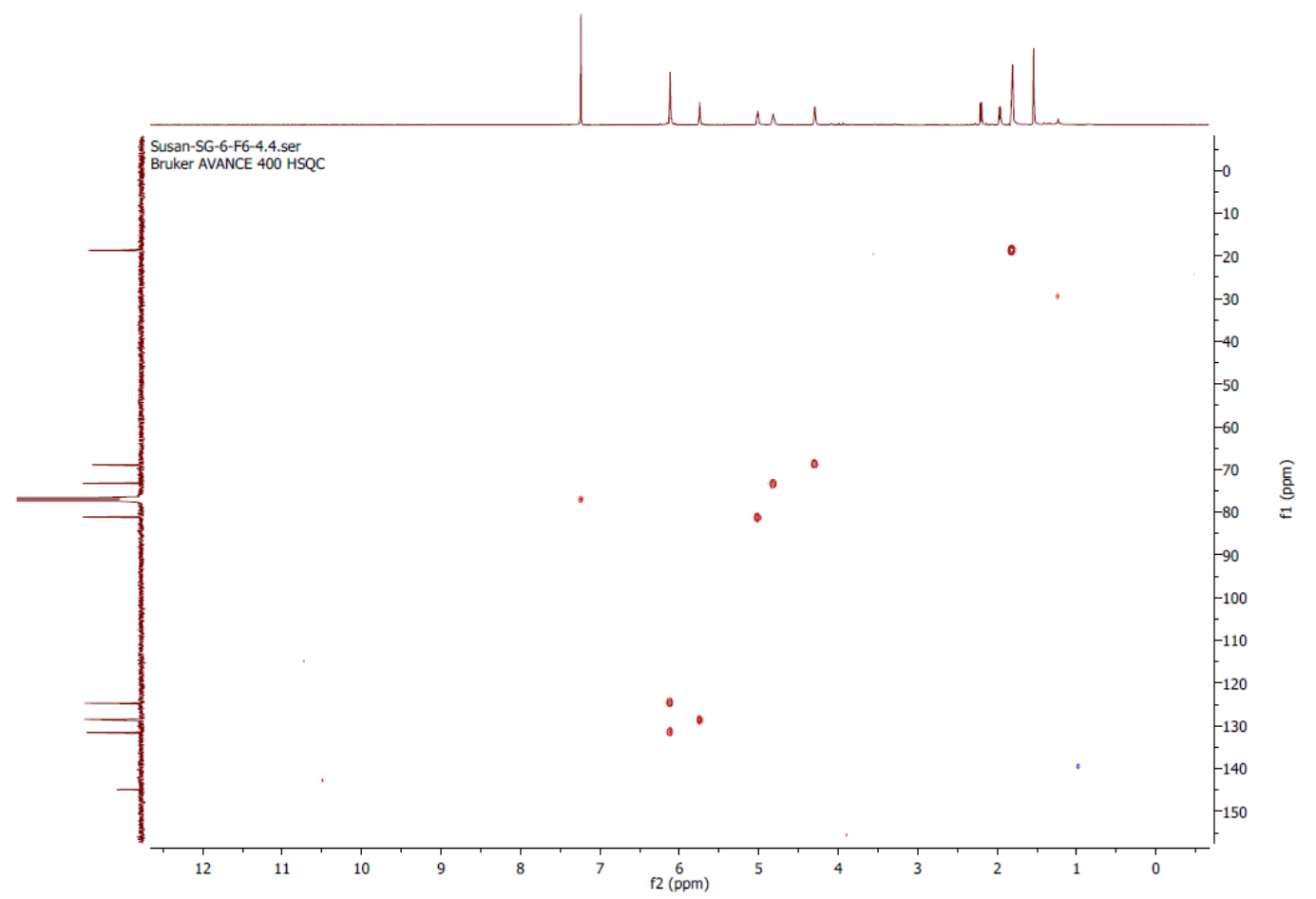

HMBC of compound $10\left(\mathrm{CDCl}_{3}, 400 \mathrm{MHz}\right)$

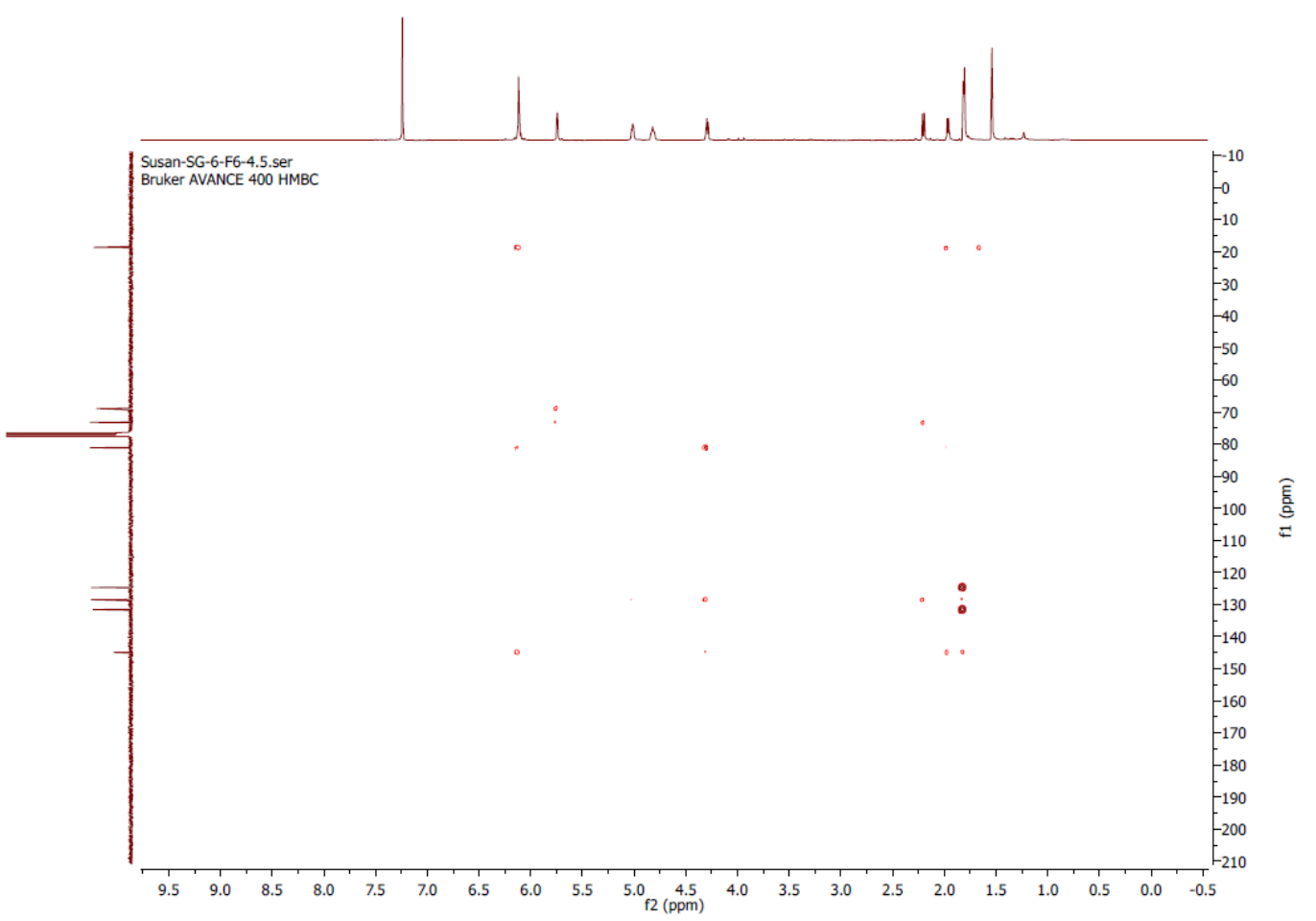


COSY of compound $\mathbf{1 0}\left(\mathrm{CDCl}_{3}, 400 \mathrm{MHz}\right)$

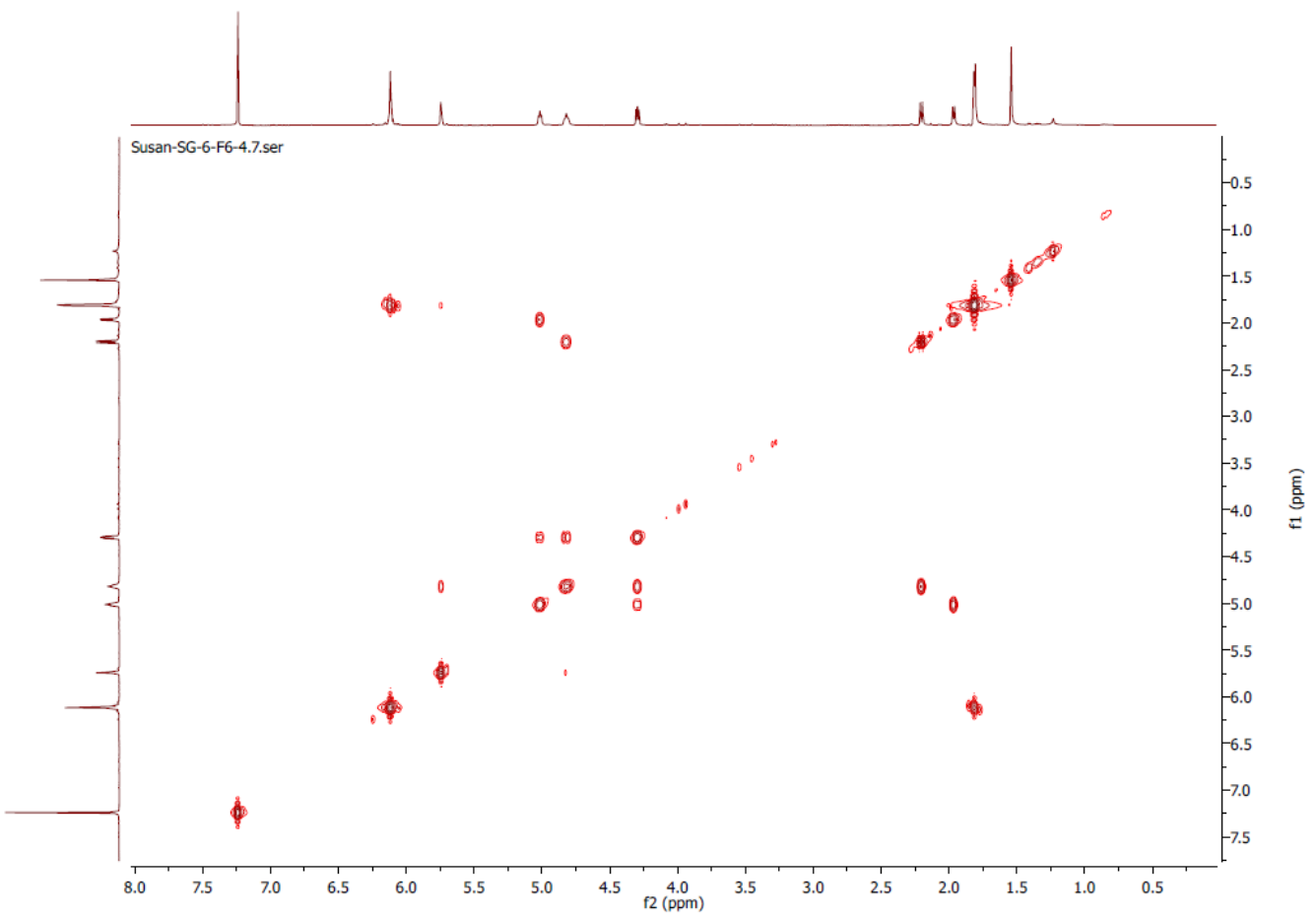

DEPT-135 of compound $\mathbf{1 0}\left(\mathrm{CDCl}_{3}, 100 \mathrm{MHz}\right)$

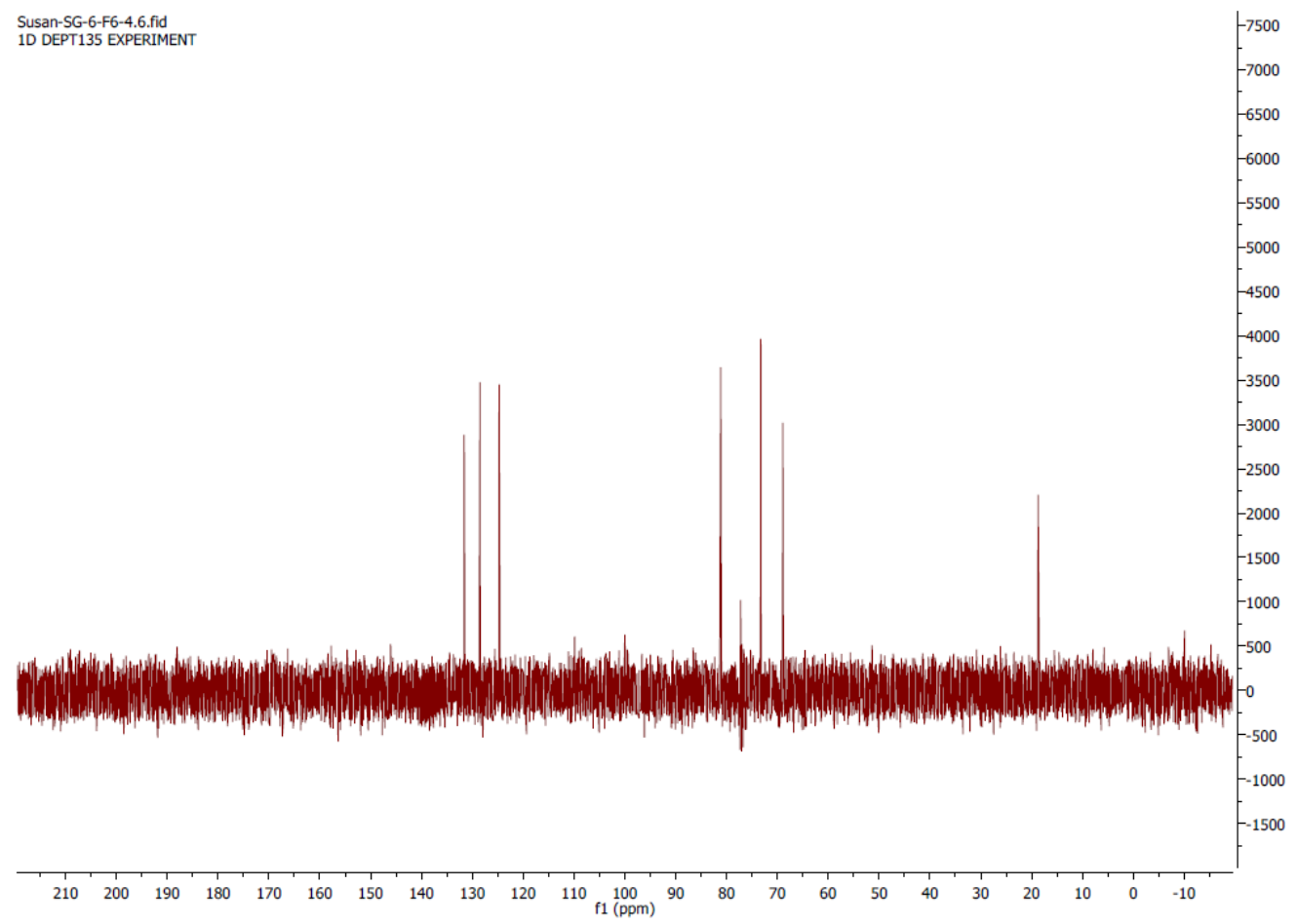


APPENDIX II - WHITE PINE ENDOPHYTE BIOACTIVITY SCREENING RESULTS 
Table 13: Bioactivity screening results of white pine endophyte extracts.

\begin{tabular}{|c|c|c|c|c|}
\hline \multirow{2}{*}{$\begin{array}{c}\text { Strain } \\
\text { I.D. }\end{array}$} & \multirow[b]{2}{*}{ Collection Site } & \multirow[b]{2}{*}{ Species } & \multicolumn{2}{|c|}{$\begin{array}{c}\text { Results of Screening } \\
\text { Bioassay }\end{array}$} \\
\hline & & & S. cerevisiae & M. violaceum \\
\hline CH-001 & Chipman, NB & & - & - \\
\hline $\mathrm{CH}-002$ & Chipman, NB & & - & - \\
\hline $\mathrm{CH}-003$ & Chipman, NB & Xylaria sp. $100 \%$ & - & - \\
\hline $\mathrm{CH}-006$ & Chipman, NB & & + & - \\
\hline $\mathrm{CH}-007$ & Chipman, NB & Xylaria sp. 98/100\% & - & - \\
\hline $\mathrm{CH}-008$ & Chipman, NB & & - & - \\
\hline $\mathrm{CH}-011$ & Chipman, NB & & - & - \\
\hline $\mathrm{CH}-013$ & Chipman, NB & & - & - \\
\hline $\mathrm{CH}-020$ & Chipman, NB & & - & - \\
\hline DT-001 & Doaktown, NB & Xylaria sp. 99/100 & - & - \\
\hline DT-003 & Doaktown, NB & Lophodermium nitens $100 \%$ & - & - \\
\hline DT-006 & Doaktown, NB & & + & + \\
\hline DT-007 & Doaktown, NB & & - & + \\
\hline DT-010 & Doaktown, NB & & - & - \\
\hline DT-011 & Doaktown, NB & Lophodermium nitens $98 \%$ & + & + \\
\hline DT-014 & Doaktown, NB & Xylaria sp. $100 \%$ & - & - \\
\hline DT-015 & Doaktown, NB & & - & - \\
\hline DT-017 & Doaktown, NB & & - & - \\
\hline DT-018 & Doaktown, NB & & - & - \\
\hline DT-019 & Doaktown, NB & & - & - \\
\hline DT-027 & Doaktown, NB & & - & + \\
\hline DT-028 & Doaktown, NB & & - & - \\
\hline DT-032 & Doaktown, NB & & & \\
\hline DT-034 & Doaktown, NB & & - & - \\
\hline DT-036 & Doaktown, NB & & - & - \\
\hline DT-039 & Doaktown, NB & & - & + \\
\hline DT-041 & Doaktown, NB & Xylaria sp. 99\% & - & - \\
\hline DT-045 & Doaktown, NB & & - & - \\
\hline DT-046 & Doaktown, NB & & - & - \\
\hline DT-053 & Doaktown, NB & Xylaria sp. $100 \%$ & - & - \\
\hline DT-061 & Doaktown, NB & & + & + \\
\hline DT-062 & Doaktown, NB & & - & - \\
\hline DT-067 & Doaktown, NB & Xylaria sp. 99\% & - & - \\
\hline DT-068 & Doaktown, NB & & - & - \\
\hline DT-069 & Doaktown, NB & & - & - \\
\hline DT-073 & Doaktown, NB & & - & + \\
\hline
\end{tabular}




\begin{tabular}{|c|c|c|c|c|}
\hline \multirow{2}{*}{$\begin{array}{c}\text { Strain } \\
\text { I.D. }\end{array}$} & \multirow[b]{2}{*}{ Collection Site } & \multirow[b]{2}{*}{ Species } & \multicolumn{2}{|c|}{$\begin{array}{c}\text { Results of Screening } \\
\text { Bioassay }\end{array}$} \\
\hline & & & S. cerevisiae & M. violaceum \\
\hline DT-079 & Doaktown, NB & & - & - \\
\hline DT-090 & Doaktown, NB & & + & + \\
\hline DT-096 & Doaktown, NB & & - & - \\
\hline DT-109 & Doaktown, NB & & - & - \\
\hline DT-113 & Doaktown, NB & & - & - \\
\hline DT-116 & Doaktown, NB & & + & + \\
\hline DT-117 & Doaktown, NB & & - & - \\
\hline DT-118 & Doaktown, NB & Lophodermium nitens $98 \%$ & - & - \\
\hline DT-121 & Doaktown, NB & & - & - \\
\hline DT-123 & Doaktown, NB & & - & - \\
\hline DT-125 & Doaktown, NB & & - & - \\
\hline DT-126 & Doaktown, NB & & + & + \\
\hline DT-132 & Doaktown, NB & & - & - \\
\hline DT-155 & Doaktown, NB & Lophodermium nitens $99 \%$ & - & - \\
\hline DT-156 & Doaktown, NB & & - & - \\
\hline DT-160 & Doaktown, NB & Lophodermium nitens $98 \%$ & + & + \\
\hline DT-164 & Doaktown, NB & & - & - \\
\hline DT-176 & Doaktown, NB & & - & - \\
\hline DT-178 & Doaktown, NB & & - & - \\
\hline DT-179 & Doaktown, NB & & - & - \\
\hline DT-181 & Doaktown, NB & & - & - \\
\hline DT-190 & Doaktown, NB & Lophodermium nitens 99\% & + & + \\
\hline DT-197 & Doaktown, NB & Phanerochaete sordida $94 \%$ & ++ & ++ \\
\hline DT-213 & Doaktown, NB & & - & - \\
\hline DT-216 & Doaktown, NB & & + & + \\
\hline DT-218 & Doaktown, NB & & - & - \\
\hline DT-220 & Doaktown, NB & Lophodermium nitens 98\% & ++ & ++ \\
\hline DT-230 & Doaktown, NB & Phlebia tremellosa 99\% & + & + \\
\hline DT-241 & Doaktown, NB & & - & - \\
\hline DT-244 & Doaktown, NB & & - & - \\
\hline DT-246 & Doaktown, NB & & - & - \\
\hline DT-256 & Doaktown, NB & Lophodermium nitens 97\% & ++ & ++ \\
\hline DT-258 & Doaktown, NB & & - & - \\
\hline DT-260 & Doaktown, NB & Lophodermium nitens 99\% & - & - \\
\hline DT-263 & Doaktown, NB & & - & - \\
\hline DT-265 & Doaktown, NB & & - & - \\
\hline DT-278 & Doaktown, NB & & - & - \\
\hline DT-287 & Doaktown, NB & & - & - \\
\hline
\end{tabular}




\begin{tabular}{|c|c|c|c|c|}
\hline \multirow{2}{*}{$\begin{array}{l}\text { Strain } \\
\text { I.D. }\end{array}$} & \multirow[b]{2}{*}{ Collection Site } & \multirow[b]{2}{*}{ Species } & \multicolumn{2}{|c|}{$\begin{array}{c}\text { Results of Screening } \\
\text { Bioassay }\end{array}$} \\
\hline & & & S. cerevisiae & M. violaceum \\
\hline DT-291 & Doaktown, NB & Lophodermium nitens 98\% & - & - \\
\hline DT-293 & Doaktown, NB & Lophodermium nitens 98\% & - & - \\
\hline DT-304 & Doaktown, NB & & - & - \\
\hline DT-310 & Doaktown, NB & & + & + \\
\hline DT-318 & Doaktown, NB & & - & - \\
\hline DT-319 & Doaktown, NB & Lophodermium nitens $97 \%$ & ++ & ++ \\
\hline DT-325 & Doaktown, NB & & - & - \\
\hline DT-327 & Doaktown, NB & & - & - \\
\hline DT-328 & Doaktown, NB & & - & - \\
\hline DT-338 & Doaktown, NB & Lophodermium nitens 98\% & - & - \\
\hline DT-357 & Doaktown, NB & & - & - \\
\hline DT-383 & Doaktown, NB & & - & - \\
\hline SX-007 & Sussex, NB & Sydowia polyspora $99 \%$ & - & - \\
\hline SX-009 & Sussex, NB & Lophodermium nitens 99\% & - & - \\
\hline SX-012 & Sussex, NB & Lophodermium nitens 99\% & +++ & +++ \\
\hline SX-017 & Sussex, NB & & - & - \\
\hline SX-019 & Sussex, NB & $\begin{array}{c}\text { Lophodermium sp. } \\
\text { (L. australe/conigenum 96\%) }\end{array}$ & - & - \\
\hline DD-001 & Deersdale, NB & Xylaria sp. 100\% & - & - \\
\hline DD-002 & Deersdale, NB & Xylaria sp. $100 \%$ & - & - \\
\hline DD-005 & Deersdale, NB & $\begin{array}{l}\text { Volutella sp. } 88 / 82 \% \\
\text { Collophora hispanica }\end{array}$ & - & - \\
\hline DD-007 & Deersdale, NB & $93 / 100 \%$ & - & - \\
\hline DD-008 & Deersdale, NB & Phoma herbarum 96\% & - & - \\
\hline DD-013 & Deersdale, NB & & - & - \\
\hline T1.1B.1 & Deersdale, NB & & - & - \\
\hline T1.1B.1-1 & Deersdale, NB & & + & + \\
\hline T1.1B.1-2 & Deersdale, NB & & - & - \\
\hline T1.3B.2 & Deersdale, NB & & + & + \\
\hline T2.1A.1 & Deersdale, NB & Xylaria sp. $100 \%$ & - & - \\
\hline T2.1B.1 & Deersdale, NB & & - & - \\
\hline $\mathrm{T} 2.2 \mathrm{~A} .1$ & Deersdale, NB & & - & - \\
\hline T2.2B.1 & Deersdale, NB & & + & + \\
\hline $\mathrm{T} 2.2 \mathrm{~B} .5$ & Deersdale, NB & & - & - \\
\hline T2.3B.4 & Deersdale, NB & & - & - \\
\hline T3.1A.2 & Deersdale, NB & Xylaria sp. 99\% & - & - \\
\hline T3.2A.1 & Deersdale, NB & & + & + \\
\hline T3.4A.1 & Deersdale, NB & & - & - \\
\hline
\end{tabular}




\begin{tabular}{|c|c|c|c|c|}
\hline \multirow{2}{*}{$\begin{array}{c}\text { Strain } \\
\text { I.D. }\end{array}$} & \multirow[b]{2}{*}{ Collection Site } & \multirow[b]{2}{*}{ Species } & \multicolumn{2}{|c|}{$\begin{array}{c}\text { Results of Screening } \\
\text { Bioassay }\end{array}$} \\
\hline & & & S. cerevisiae & M. violaceum \\
\hline T4.2A.1 & Deersdale, NB & & - & - \\
\hline T4.2A.2 & Deersdale, NB & & + & + \\
\hline T4.2A.3 & Deersdale, NB & Xylaria sp. $100 \%$ & - & - \\
\hline T4.3A.1 & Deersdale, NB & & - & + \\
\hline T4.3A.2 & Deersdale, NB & Xylaria sp. 99\% & - & - \\
\hline T5.1A.1 & Deersdale, NB & & - & - \\
\hline T5.1B.1 & Deersdale, NB & Xylaria sp. 99\% & ++ & ++ \\
\hline T5.3B.4 & Deersdale, NB & Lophodermium nitens 99\% & - & - \\
\hline T5.2B.6 & Deersdale, NB & & - & - \\
\hline T5.4B.1 & Deersdale, NB & Xylaria sp. $98 \%$ & - & - \\
\hline T6.3B.1 & Deersdale, NB & Dothidiomycete sp. & - & - \\
\hline T6.3A.2 & Deersdale, NB & & + & + \\
\hline T6.3A.4 & Deersdale, NB & Xylaria sp. & - & - \\
\hline T6.4B.2 & Deersdale, NB & Xylaria sp. & + & + \\
\hline T6.4A.1 & Deersdale, NB & & + & + \\
\hline T6.4A.2 & Deersdale, NB & Xylaria sp. & + & + \\
\hline T6.5A.2 & Deersdale, NB & & - & - \\
\hline & & $\begin{array}{l}\text { Pleosporales, putative new } \\
\text { lineage in family }\end{array}$ & & \\
\hline SG-006 & Saint-George, NB & Massarinaceae & +++ & +++ \\
\hline SG-008 & Saint-George, NB & Xylaria sp. $100 \%$ & - & - \\
\hline SG-013 & Saint-George, NB & & + & + \\
\hline & & $\begin{array}{l}\text { Pleosporales, putative new } \\
\text { lineage in family }\end{array}$ & & \\
\hline SG-015 & Saint-George, NB & Massarinaceae & +++ & +++ \\
\hline SG-017 & Saint-George, NB & & - & - \\
\hline SG-018 & Saint-George NB & uncultured Basidiomycete & - & _- \\
\hline SG-019 & Saint-George, NB & Lophodermium nitens $100 \%$ & - & - \\
\hline SG-023 & Saint-George, NB & & + & + \\
\hline SG-024 & Saint-George, NB & $\begin{array}{l}\text { Lophodermium nitens } 98 \% \\
\text { no close match except }\end{array}$ & - & - \\
\hline SG-021 & Saint-George, NB & "uncultured Basidiomycete" & - & - \\
\hline
\end{tabular}

